\title{
Collected Papers on Caddoan Archaeology in the Upper Sabine River Basin, Northeastern Texas
}

Timothy K. Perttula

Heritage Research Center, Stephen F. Austin State University

Follow this and additional works at: https://scholarworks.sfasu.edu/ita

Part of the American Material Culture Commons, Archaeological Anthropology Commons, Environmental Studies Commons, Other American Studies Commons, Other Arts and Humanities Commons, Other History of Art, Architecture, and Archaeology Commons, and the United States History Commons

Tell us how this article helped you.

This Article is brought to you for free and open access by the Center for Regional Heritage Research at SFA ScholarWorks. It has been accepted for inclusion in Index of Texas Archaeology: Open Access Gray Literature from the Lone Star State by an authorized editor of SFA ScholarWorks. For more information, please contact cdsscholarworks@sfasu.edu. 


\section{Collected Papers on Caddoan Archaeology in the Upper Sabine River Basin, Northeastern Texas}

\section{Creative Commons License}

\section{(c) (i) (9)}

This work is licensed under a Creative Commons Attribution-NonCommercial 4.0 International License 


\section{Collected Papers $\mathbf{O N}_{\mathbf{N}}$ Caddoan Archabology

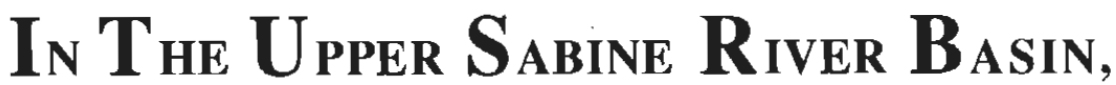 Northeastern Texas}

Timothy K. Perttula

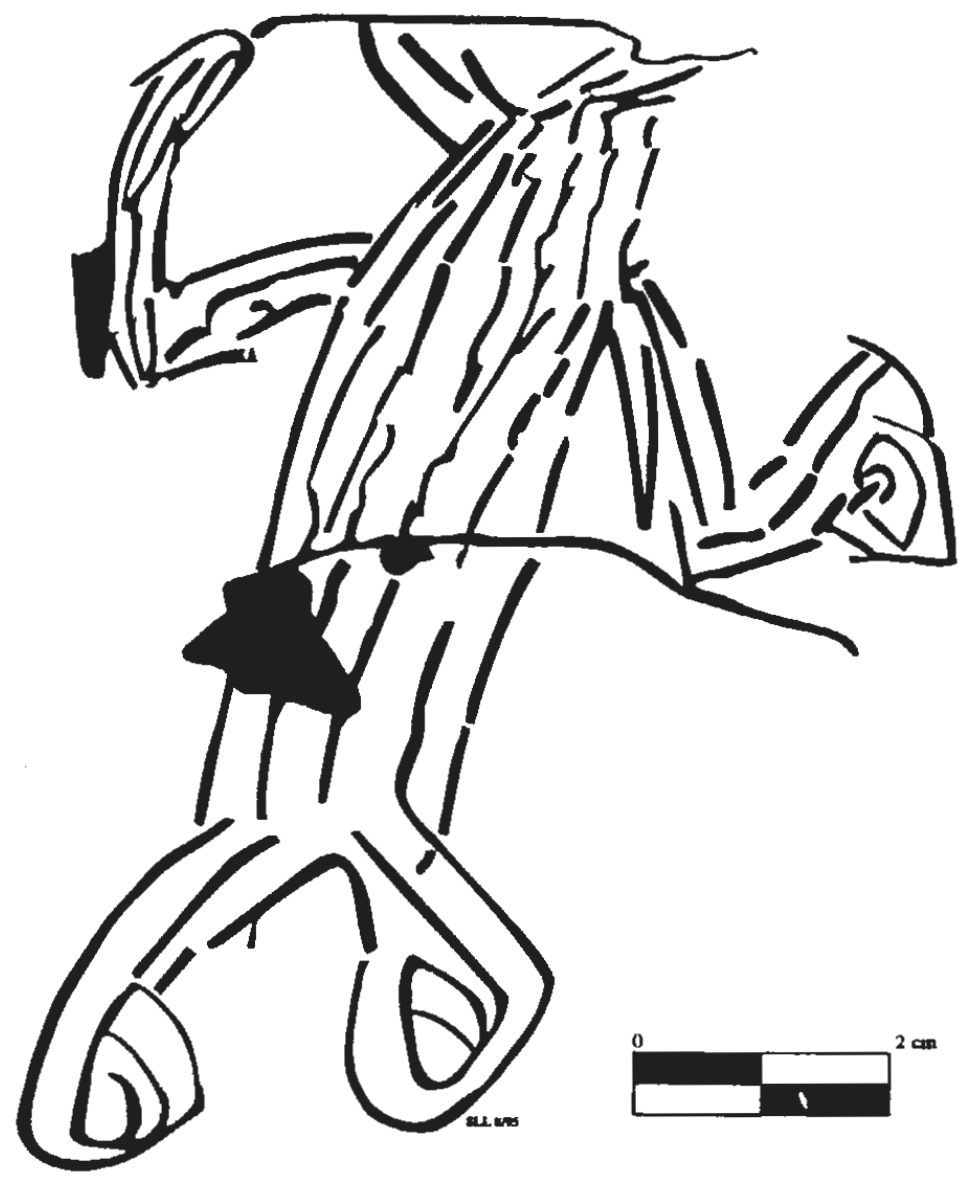

Special Publication No. 1 of the Friends

of Northeast Texas Archaeology 


\section{FRIENDS OF NORTHEAST TEXAS ARCHAEOLOGY WEB SITE ADDRESS http://www.skiles.net/fneta}

The Friends of Northeast Texas Archaeology are grateful to the following for permission to reprint copyrighted material: Plains Anthropological Society, the Texas State Historical Association, the Texas Archeological Society, the Board of Trustees for the Center for Archaeological Investigations, Southern Illinois University, and the Dallas Archeological Society. The chapter entitled "Patterns of Prehistoric Lithic Raw Material Utilization in the Caddoan Area: The Western Gulf Coastal Plain" originally appeared in Prehistoric Chert Exploitation: Studies from the Midcontinent, edited by Brian M. Butler and Ernest E. May, Center for Archaeological Investigations Occasional Paper No. 2, copyright by the Board of Trustees, Southern Illinois University, 1984.

\section{ISSN 1091-9880}

Cover Illustration: Anthropomorphic fïgure from Monkstown Fingernail Impressed vessel (Vessel 1, Burial 1), site 41WD109. Illustration by Sue E. Linder-Lindsay, Courtesy of the Department of Anthropology, Southern Methodist University, Dallas, Texas 


\title{
Collected Papers $\mathbf{O N}_{\mathrm{N}}$ Caddoan Archaeology In The U PPER S Abine River B Asin, Northeastern Texas
}

\author{
Timothy K. Perttula \\ with contributions by \\ James E. Bruseth \\ Bob D. Skiles \\ $\&$ \\ Bonnie C. Yates
}

1995

Friends of Northeast Texas Archaeology, Special Publication No. 1 (1995) 


\section{,}




\section{Contents}

- Sources iv

- Introduction v-vii

Timothy K. Perttula

Rains County, Texas

Timothy K. Perttula and Bob D. Skiles

- $\quad$ Early Caddoan Subsistence Strategies, Sabine River Basin, East Texas

Timothy K. Perttula and James E. Bruseth

- The Taddlock Site

Timothy K. Perttula

- The Carlisle Site (41WD46), a Middle Caddoan Occupation on the

Sabine River, Wood County, Texas

Timothy K. Perttula, Bob D. Skiles, and Bonnie C. Yates

- Caddoan Mound Sites in the Sabine River Basin of Northeast Texas

Timothy K. Perttula

- Patterns of Prehistoric Lithic Raw Material Utilization in the Caddoan Area: The Westem Gulf Coastal Plain

Timothy K. Perttula

- The Goldsmith Site (41WD208): Investigations of the Titus Phase in the Upper Sabine River Basin, Wood County, Texas

Timothy K. Perttula, Bob D. Skiles, and Bonnie C. Yates

- $\quad$ Another Look at an Eighteenth-Century Archaeological Site in Wood County, Texas

Timothy K. Perttula and Bob D. Skiles

$105-124$

Concluding Remarks: The Future of Upper Sabine River Basin

Archaeology

Timothy K. Perttula

$125-177$ 


\section{SourCES}

Perttula, Timothy K.

1984 Patterns of Lithic Raw Material Utilization in the Caddoan Area: The Western Gulf Coastal Plain. In Prehistoric Chert Exploitation: Studies from the Midcontinent, edited by B.M. Butler and E.E. May, pp. 129-148. Occasional Paper 2. Center for Archaeological Investigations, Southern Illinois University, Carbondale.

1994 Caddoan Mound Sites in the Sabine River Basin of Northeast Texas. Caddoan Archeology Newsletter, Volume IV, No. 4:4-19.

1995 The Taddlock Site. In The New Handbook of Texas, 3rd edition. Texas State Historical Association, Austin.

Perttula, Timothy K. and James E. Bruseth

1983 Early Caddoan Subsistence Strategies, Sabine River Basin, East Texas. Plains Anthropologist 28 (99):9-21.

Perttula, Timothy K. and Bob D. Skiles

1988 41RA65, An Early Ceramic-Early Caddoan Period Site on Garrett Creek, Rains County, Texas. The Record, 50th Anniversary Edition, Volume 42 (3):69-81. The Dallas Archeological Society.

1989 Another Look at an Eighteenth-Century Archaeological Site in Wood County, Texas. Southwestern Historical Quarterly 92(3):417-435.

Perttula, Timothy K., Bob D. Skiles, and Bonnie C. Yates

1993a The Carlisle Site (41WD46), a Middle Caddoan Occupation on the Sabine River, Wood County, Texas. Notes on Northeast Texas Archaeology, No. $1: 34-62$.

1993b The Goldsmith Site (41WD208): Investigations of the Titus Phase in the Upper Sabine River Basin, Wood County, Texas. Bulletin of the Texas Archeological Society 61:139-191. 


\section{INTRODUCTION}

This Special Publication of the Friends of Northeast Texas Archaeology presents a series of papers written and published between 1983-1994 on various aspects of the archaeology of the Upper Sabine River basin in Northeast Texas (Figure 1). Their particular focus is on the lifeways and material culture of the Caddoan peoples who permanently settled in the basin between about A.D. 700-800 (if not earlier) and the mid$1700 \mathrm{~s}$.

This part of Northeast Texas has a highly significant and diverse archaeological record, one that has intrigued professional and avocational archaeologists alike for at least 75 years (e.g., Pearce 1920; Johnson and Jelks 1958; Johnson 1962; Bruseth and Perttula 1981; Granberry 1985; Friedell and Skinner 1995). However, we still know very little about the prehistoric and early historic Caddoan groups who lived in the basin, and unfortunately it has been a number of years since dedicated archaeologists, professional or avocational, turned their attention to this region; on the other hand, looters and vandals who want to make a profit from their plunder of the past have not overlooked the region.

Thus, the publication of this compilation of papers serves two purposes: first, to make accessible in onc document an integrated and coherent series of papers that illustrate the interesting and dynamic nature of Caddoan archaeology in the Upper Sabine River basin, and second, to foster a renewed interest in studying the regional Caddoan archaeological record. Hopefully, this will help to effectively communicate the results of archaeological investigations to interested members of the public and the Caddo Tribe (something that professional archaeologists in Texas and elsewhere have fallen fall short of accomplishing successfully [Jameson 1994]), and in turn will engender the continued quest for knowledge about the past in a spirit of protection and enhancement of the region's archaeological resourccs. 


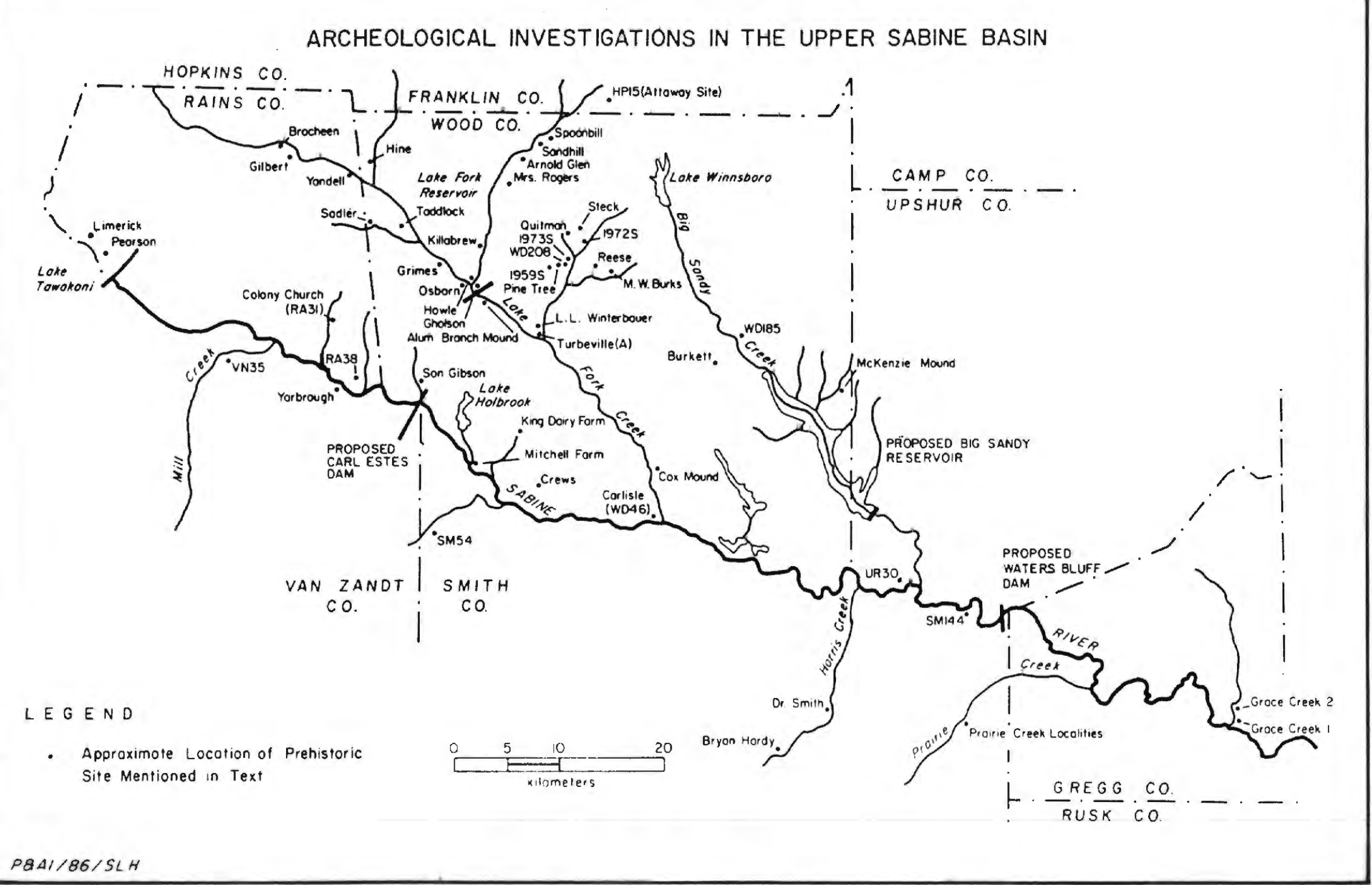

Figure 1. Archeological Investigations in the Upper Sabine River basin (from Perttula et al. 1986). 


\section{REFERENCES CITED}

Bruseth, J. E, and T. K. Perttula

1981 Prehistoric Settlement Patterns at Lake Fork Reservoir. Texas Antiquities Permit Series, Report No. 2. Texas Antiquities Committee, Austin, and Southern Methodist University, Dallas.

Friedell, D. L. and S. A. Skinner (editors)

1995 William T. McKenzie Mound, by Doyle Granberry. The Record, Volume 46, No. $1: 1-18$.

Granberry, D. S.

19858 C-14 Dates from the McKenzie Mound Site, 4 I WD55. The Record, Volume 40, No. 2:4-9.

Jameson, J. H., Jr.

1994 The Importance of Public Outreach Programs in Archaeology. SAA Bulletin 12(3):16- 17 .

Johnson, L., Jr.

1962 The Yarbrough and Miller Sites of Northeastern Texas, with a Preliminary Definition of the LaHarpe Aspect. Bulletin of the Texas Archeological Society 32:141-284.

Johnson, L., Jr. and E. B. Jelks

1958 The Tawakoni-Yscani Village, 1760: A Study in Archeological Site Identification. The Texas Journal of Science 10:405-422.

Pearce, J. E.

1920 Early Work in East Texas. MS on file, Texas Archeological Research Laboratory, The University of Texas at Austin.

Perttula, T. K., B. D. Skiles, M. B. Collins, M. C. Trachte, and F. Valdez, Jr.

1986 This Everlasting Sand Bed": Cultural Resources Investigations at the Texas Big Sandy Project, Wood and Upshur Counties, Texas. Reports of Investigations No. 52. Prewitt and Associates, Inc., Austin. 


\title{
41RA65, AN EARLY CERAMIC - EARLY CADDOAN PERIOD SITE ON GARRETT CREEK, RAINS COUNTY, TEXAS
}

\author{
Timothy K. Perttula and Bob D. Skiles
}

\section{INTRODUCTION}

This paper concerns the results of limited investigations undertaken in the spring of 1986 at 41RA65, an earthen midden containing abundant ceramic and lithic artifacts dating to the Early Ceramic Period (200 B.C. - A.D. 800) and Early Caddoan Period I/II (A.D. $800-1400$ ). This site is located on an upland projection adjacent to the margins of Lake Fork Reservoir in Rains County, Texas. It was discovered in 1975 by the Archaeology Research Program at Southern Methodist University during a survey of the upper end of the thenproposed Lake Fork Reservoir (Bruseth et al. 1977:Figure 13). SMU tested the site the same field season, recovering 75 artifacts in the excavation of 12 systematically placed postholes across the site (Bruseth et al. 1977:165). Ceramics and one dart projectile point found in the postholes suggested that the site was occupied during Archaic and Caddoan periods.

The site was not recommended for excavations during the mitigation phase of the archaeological research at Lake Fork Reservoir (Bruseth et al. 1977), because it would not be directly affected by the reservoir inundation. Indirect affects of the completed reservoir have been severe, however. Subsequent to reservoir filling in 1982 the area around Lake Fork has been witness to considerable lakeshore development. This part of the lakeshore has been partially bulldozed for a new road connecting a series of staked-out house lots. That activity has exposed several new archaeological sites, and disturbed 41RA65 (and 41RA66, $400 \mathrm{~m}$ to the westnorthwest of 41RA65). This disturbance was noted during a 1986 reconnaissance of Lake Fork Reservoir, and led us to return to the site to assess its condition. We found that the site had been stripped bare of vegetation and most of the A horizon on the point of the upland projection had been pushed downslope by a bulldozer. Quantities of cultural material were exposed on the cleared surface and in the fill downslope. The site was also being used as a convienent fishing spot. Thus, the in situ site deposits have probably been removed entirely as a result of land development arising from lake construction. Our work at the site was a belated attempt to recover as much useful information about the archaeological record here as possible before all evidence of it is erased.

\section{SETTING}

41RA65, located approximately $6 \mathrm{~km}$ north of the community of Emory, Texas, and $5 \mathrm{~km}$ south of the Rains and Hopkins County line, is situated along an interstream divide between the Garrett Creek Valley and Lake Fork Creek. Garrett Creek is a permanent flowing stream which originates in SW Hopkins County along margins of the Blackland Prairie. It flows in a northwestsoutheast direction to its present confluence with Lake Fork Creek near the Rains-Woods County line below the site. In the last $5-6 \mathrm{~km}$ of its course it runs in an old Lake Fork Creek channel that parallels the steep, dissected north valley wall of the Lake Fork Creek floodplain. The combined Lake Fork Creek-Garrett Creek floodplain ranges between $1-2 \mathrm{~km}$ in width, then constricts to half that width at the confluence of the two streams near less resistant Eocene age Wilcox Group bedrock outcrops.

The Garrett Creek floodplain by the site is about 800 meters wide, and is marked by three distinct channel meanders from previous Garrett Creek courses. One old course of Garrett Creek is situated at the base of the upland projection about $40 \mathrm{~m}$ from the site. At the time of the prehistoric occupations it is likely that this Garrett Creek channel was the primary stream course. The proximity of a stable, elevated landform with a permanent stream course is a rare topographic setting in this area where streams slowly meander through wide valleys and only infrequently flow near valley walls. It is an uplandfloodplain edge setting that was commonly selected for prehistoric settlement locations during certain periods of time (Bruseth and Perttula 1981:133-138).

This part of the Lake Fork Creek-Garrett Creek drainage is in the Oak-Hickory or Post Oak Savannah biotic association. This association is a relatively narrow woodland band, and a natural transition zone between the Blackland Prairie to the west and the more mesic OakHickory-Pine Forest of Pineywoods to the east. Upland areas were primarily covered with a widely.spaced medium-tall to tall post oak-blackjack oak savannah overstory, and pecan, oaks, hackberry, elm, sweetgum, and other hardwoods grew near the riverbank, and in the floodplains of the two streams. The interested reader is referred to Bruseth et al. (1977:5-19) for further details on 
the natural biotic communities in this section of the Lake Fork Creek basin.

41RA65 is situated on shallow Woodtell loam soils averaging $27 \mathrm{~cm}(10 \mathrm{in})$ in thickness (Lane 1977:23; Bruseth et al. 1977:165). In SMU's survey the site was recognized only as a scatter of ceramics and lithic cultural materials over a $300 \times 60 \mathrm{~m}$ area of the upland projection. The total extent of the midden deposits now known to be present on the site is difficult to determine because of bulldozer disturbances, but probably covered at least $2000 \mathrm{sq} \mathrm{m}$ on the crest of the landform.

Similar types of prehistoric sites include 41RA66, $41 \mathrm{RA} 79$, and $41 \mathrm{RA} 83$ within a one $\mathrm{km}$ radius of $41 \mathrm{RA} 65$, and others are known within a $5 \mathrm{~km}$ radius (Bruseth et al. 1977; Bruseth and Perttula 1981). The Gilbert Site (41RA13), which also has an Early Caddoan component (Jelks 1967:185), is about $1.2 \mathrm{~km}$ southwest of 41RA65.

\section{INVESTIGATIONS}

Our investigations at the site were limited to a surface collection of those areas where large quantities of cultural material had been exposed by bulldozing and road traffic. Because of this disturbance no attempt was made to either carry out any excavations, or employ systematic surface collection procedures. Instead we concentrated on: (1) collecting all observable lithic tools and pottery sherds, regardless of size, and (2) selectively gathering lithic debitage and fire cracked rock. In the case of lithic debitage, our grab sample was accumulated with the intent of first documenting the diversity in raw material types present in the site assemblage; secondly, to amass a relatively representative sample of debitage classes; and finally, to gather a large enough overall sample that usemodified and/or small intentionally modified tools might be included by chance. Because of their bulk, no attempt was made to collect representative samples of fire cracked rock.

It should be pointed out that immediately prior to our investigations, a church group from Sulphur Springs, Texas had spent approximately one hour on the site collecting projectile points. About fifteen whole projectile points were removed from the site by this party, but we were able to ascertain that broken tools, lithic debitage, and ceramic sherds were not collected.

\section{PREHISTORIC ARTIFACTS}

Over 500 artifacts were recovered in surface collections at 41RA65 (Table 1). Time - diagnostic lithic and ceramic artifacts present suggest that two components can be defined - Early Ceramic (ca. 200 B. C. - A.D. 800) and Early Caddoan Period I/II (A.D. $800-1400$ ) in affiliation. Given the topographic setting of the site, the shallow cultural deposits, and the nature of the collection, it is virtually impossible to assign each artifact class or typological category to one component or the other. Associated chronological and typological information presented in Bruseth and Perttula (1981), Johnson (1962), and Thurmond $(1981,1985)$ was important in reasonably segregating certain artifact classes, and developing more specific temporal estimates for the two components at 41RA65.

Table 1

INVENTORY OF CULTURAL MATERIAL RECOVERED FROM 41RA65 (X41RA9*)

$\begin{array}{lr}\text { Lithic Debitage } & 270 \\ \text { Cores } & 9 \\ \text { Thick Bifaces } & 7 \\ \text { Thin Bifaces } & 12 \\ \text { PP/K } & 6 \\ \text { Arrowpoint } & 1 \\ \text { Utilized Pieces } & 13 \\ \text { Axe Fragment } & 1 \\ \text { Fire Cracked Rock } & 9 \\ \text { Ceramic Rim Sherds } & 14 \\ \text { Ceramic Body Sherds } & 197 \\ \text { Ceramic Base Sherds } & 10\end{array}$

* The X41RA9 site number was assigned by SMU

\section{POTTERY}

A total of 221 pottery sherds were recovered from the site. Grog (crushed sherds)-grit tempered pottery represents $86.4 \%$ of the sample, while bone tempered pottery accounts for only $13.6 \%$ (Table 2 ).

Table 2

TEMPER AND SHERd LOCATION

\begin{tabular}{cccc}
\hline Rim & Body & Base & Number \\
\hline Bone Temper & & & \\
2 & 24 & 4 & 30 \\
$\begin{array}{c}\text { Grog-Grit Temper } \\
12\end{array}$ & 173 & 6 & 191 \\
Total Number: & & & 221
\end{tabular}


The two pottery categories were further subdivided by differences in the apparent density of the temper in the paste (e.g. Rogers et al. 1985). Without attempting a detailed quantification of temper particles visible in sherd cross-sections, and also acknowledging the difficulties enumerated by Sheperd (1976:26) in assessing temper densities, we have separated the sherds into fine and coarse tempered wares. These divisions approximate the differences between $10 \%$ and $30 \%$ temper by volume employed by Rogers et al. (1985:Figure 2) in their study of temper quantification.

Coarse bone tempered pottery represents $5.4 \%$ of the ceramic assemblage, while the coarse grog-grit tempered class accounts for $30.3 \%$. Sixty-four percent of the ceramics from 41RA65 are fine tempered pottery sherds; $8 \%$ of these are tempered with bone, the remainder having been tempered with grog and grit aplastics. Plain and decorated body sherds from each of these categories were measured for thickness, demonstrating that coarse groggrit tempered sherds are thicker than the other pottery groups (Table 3).

Variations in sherd thickness within the four groups, in combination with differences in surface treatment, suggest that two distinctive wares are present in the 41RA65 assemblage. They are: (1) a relatively thin bone and grog-grit tempered pottery of both fine and coarse paste, with slipped, engraved, and incised rim and body

Table 3

\section{Temper/Paste Categories and Thickness MEASUREMENTS}

\begin{tabular}{cccc}
$\begin{array}{c}\text { Temper/Paste } \\
\text { Categories }\end{array}$ & $\begin{array}{c}\text { Mean Thickness } \\
(\mathrm{mm})\end{array}$ & $\begin{array}{c}\text { Standard } \\
\text { Deviation (mm) }\end{array} \quad \mathrm{N}^{*}$ \\
\hline
\end{tabular}

\begin{tabular}{|c|c|c|}
\hline $\begin{array}{l}\text { Bone/fine/ } \\
\text { body sherd }\end{array}$ & 6.77 & 0.54 \\
\hline $\begin{array}{l}\text { Bone/coarse/ } \\
\text { body sherd }\end{array}$ & & \\
\hline $\begin{array}{l}\text { body sherd } \\
\text { Bone/fine/engraved }\end{array}$ & $\begin{array}{l}7.25 \\
633\end{array}$ & 0.71 \\
\hline $\begin{array}{l}\text { Bone/fine/engraved } \\
\text { Grog-grit/fine/ }\end{array}$ & 6.33 & 0.44 \\
\hline $\begin{array}{l}\text { body sherd } \\
\text { Groo-orit/fine/ }\end{array}$ & 6.78 & 0.75 \\
\hline $\begin{array}{l}\text { Grog-grit/fine/ } \\
\text { plain rim } \\
\text { Grog-grit/fine/ }\end{array}$ & 6.10 & 0.99 \\
\hline $\begin{array}{l}\text { red slipped } \\
\text { Grog-grit/coarse/ }\end{array}$ & 5.50 & 0.67 \\
\hline $\begin{array}{l}\text { body sherd } \\
\text { Grog-grit/coarse/ }\end{array}$ & 8.23 & 1.00 \\
\hline large punctations & 8.67 & 1.11 \\
\hline
\end{tabular}

surface treatments common; and (2) a relatively thick, coarse grog-grit tempered pottery decorated only with large punctations.

The first group, comprising $69.7 \%$ of the ceramic assemblage, clearly belongs to the Caddoan ceramic tradition. The remainder of the ceramics, the second group, does resemble the Caddoan ceramics in a general sense, but here are suggested to actually represent an Early Ceramic Period ceramic assemblage at 41RA65. The identification of an Early Ceramic assemblage is based on recognized differences in sherd thickness between the two groups, paste characteristics, and similarities to the Resch Site, a well-described Early Ceramic Period component in the Upper Sabine Basin (Webb et al. 1969:18-43).

The Early Ceramic Period is characterized in East Texas by the development of two different ceramic technologies: a sandy paste ware and a grog- and sometimes bone-tempered ware (Story 1981:146). The latter is often identified as Williams Plain (Brown 1971:42-58), a thick (10 mm or more) ceramic ware dominated by "flowerpots" and simple bowls with flat disk bases. The thickness criteria developed in Southeast Oklahoma and Southwest Arkansas for catetgorizing and/or recognizing Williams Plain (e.g. Rohrbaugh 1985; Schambach 1982) often are not applied uniformly in East Texas studies, making direct comparisons difficult between different Early Ceramic Period assemblages.

In general, Williams Plain seems to occur in greater frequencies per site and in more sites north of the Sabine and Sulphur Rivers, while sandy paste wares are common from south of the Sabine River to the Gulf Coast (Story 1981:146). However, Williams Plain ceramics are not common in Upper Sabine Basin components dating to the Early Ceramic Period (Bruseth and Perttula 1981; Webb et al. 1969).

The Early Ceramic component ceramic assemblage at the Resch Site is comprised of sand, bone, and clay tempered wares with only a limited amount of decorated pottery. The Resch ceramics average $7.69 \mathrm{~mm}$ in thickness, ranging between $7.0-8.3 \mathrm{~mm}$ for the different wares (Webb et al. 1969:Table 1). The Williams Plain identified from the site included clay and bone tempered ceramics between $7-9 \mathrm{~mm}$ in thickness. The decorated pottery includes Tchefuncte Stamped, Churupa Incised, Marksville Incised var. Yokena, Troyville Stamped, and Marksville Stamped, all Lower Mississippi Valley types dating prior to ca. A.D. 500 (Williams and Brain 1983:Figure 12.1). While the four corrected radiocarbon dates from Resch range from 500 B.C. to A.D. 125 (e.g. Webb et al. 1969:95), their stratigraphic contexts are too mixed for these to be regarded as suitable dates.

Defined Early Ceramic components at Lake Fork Reservoir are suspected to date later than those at Resch because the ceramic assemblages consist mainly of horizontally incised decorative motifs confined to vessel rims, along with other incised and punctated motifs (Bruseth and Pertulla 1981:Table 5-9). This method of 
ceramic decoration is analogous to Coles Creek Incised. Diagnostic Coles Creek Incised pottery, including var. Coles Creek and var. Greenhouse, have been recovered from Grace Creek and Resch (Jones 1957; Webb et al 1969). These varieties of Coles Creek Incised date to ca. A.D. $700-850$ in the Lower Mississippi Valley (Williams and Brain 1983).

\section{Caddoan Ceramic Assemblage}

Only eleven sherds in the Caddoan ceramic assemblage were decorated; this amounts to $7.1 \%$ of the sample. An additional $3.2 \%$ have a hematite derived red slip or film, and $15 \%$ were bumished (Table 4). Because of differential preservation of sherds it is likely that the percentages of slipping and burnishing are underrepresented in the assemblage. Partially eroded and water worn sherds were noted in the collection. and Pertulla 1981:Table 5-4). The red slipped pottery from 41RA65 is present in both bottle and bowl vessel forms similar to whole vessels recovered at the Yarbrough Site on the Sabine River in Van Zandt County, Texas (Johnson 1962:Figure 22c, g).

The three engraved sherds are represented by two direct standing rims (Brown 1971: Figure 2) and a body sherd from an undetermined vessel form (Figure 1c, d). One of the engraved rim sherds derives from a carinated bowl, a common vessel form for Sanders Engraved (Suhm and Jelks 1962:137). Motifs identified include diagonal engraved lines along the rim panel, and an engraved-filled triangle (probably pendent from the rim or from horizontal engraved lines). The sherd and motif are too small to discern the complete decorative element. Engraved-filled triangles are an important stylistic marker for post-A.D. 1000 Caddoan sites in the Lake Fork Reservoir (Bruseth and Perttula 1981:86).

Incised vessels are represented by 7 sherds(Figure 1e,

Table 4

Temper and Surface Treatment Associations

Temper/Paste

Categories N Burnished Slipped Decorated Engraved Incised Punctate Plain Rim

$\begin{array}{lrrl}\text { Bone/Coarse } & 12 & & \\ \text { Bone/Fine } & 18 & 5 & \\ \text { Grog-grit/Coarse } & 67 & 7 & 1 \\ \text { Grog-grit/Fine } & 124 & 18 & 5 \\ \text { Total: } & 221 & 30 & 6\end{array}$

1

2

4

8

15

$\begin{array}{cccc}2 & 1 & & 1 \\ 1 & 6 & 4 & 1 \\ 3 & 7 & 5 & 9\end{array}$

1h). Both diagonal and cross-hatched incised decorative elements common to the type Canton Incised (Suhm and Jelks 1962:23) are present. At the Osborn site (41WD73) in Lake Fork Reservoir, diagonal incised motifs accounted for $60 \%$ of the Canton Incised sherds. The Osborn assemblage has been dated to A.D. $775 \pm 68$ (TX-3049, corrected). By contrast, diagonal incised Canton Incised represented less than $40 \%$ of all Canton Incised sherds at the ca. A.D. 960 - 1150 Taddlock occupation, and only $20 \%$ from the later Spoonbill (41WD109) component (Bruseth and Pertula 1981:Table 5-8). While changes in the frequency of diagonal and cross-hatch incised motifs apparently have temporal significance in the Upper Sabine Basin, the sample from 41RA65 is too small to be compared with the Lake Fork Reservoir sites in this respect.

Only one small punctated sherd of a fine grog-grit temper was recovered in the 41RA65 surface collection. The decoration is apparently a row of fingernail 
punctations. Punctations in an Early Caddoan context do occur in association with incised motifs, as well as an independent decorative element.

A variety of rim shapes are present in the Early Caddoan ceramic assemblage (Table 5). Standing rims straight or vertically oriented - account for $92 \%$ of the rims in the small sample. A direct rim is one that has no change in thickness or orientation in the vessel contour (Brown 1971:19), while beveled, rolled, and thickened rims are elaborations to the body of the rim.

Table 5

\section{Rim Classification}

\begin{tabular}{ccccc}
\hline Rim & Bone/ & Bone/ & Grog-Grit/ & Grog-Grit/ \\
Class & Coarse & Fine & Coarse & Fine \\
\hline
\end{tabular}

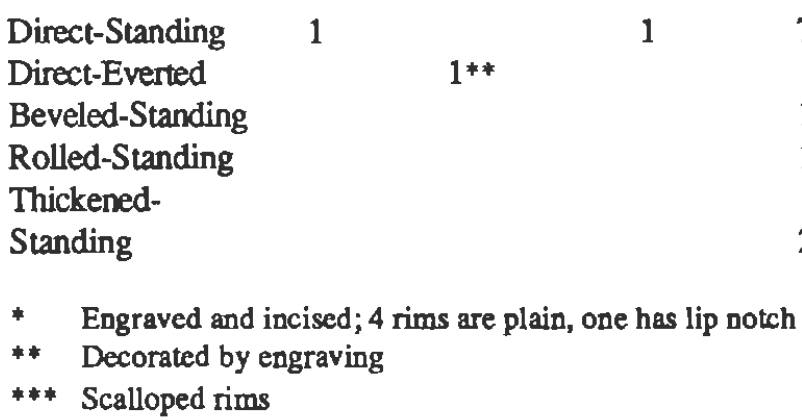

Ten of the rims are plain, though three have lip notches or scallops (Figure 1b). The vessel with lip notching is a small simple bowl. Vessel lip notching has been noted in an Early Caddoan context at the Yarbrough (Johnson 1962:Figure 23i), Limerick (Duffield 1961:88), and Sanders (Krieger 1946:186) Sites in East Texas. Occasionally lip notching is associated with the addition of a thin strip of clay added to the interior of the vessel to create an interior thickened rim, though this was not done on the 41RA65 specimen.

The scalloped rims have been thickened at the lip, but do not have an interior thickened or collared profile. Scalloped rim Sanders Plain and other undecorated Caddoan wares are present in the large collection from the Sanders Site (Krieger 1946:Plate 24b, c).

\section{Possible Early Ceramic Assemblage}

Four punctated sherds were recovered from vessels that were manufactured using a thick coarse grog-grit temper/paste. The punctations appear to be aligned in paraillel rows, probably on the rim panel (Figure 1f, $g$ ). The large punctations (Figure 1f) were made by applying a round stick of hollow cane to the unfired vessel surface.
The small punctations were apparently made with a sharp pointed implement that did not displace the still-plastic clay on the vessel surface (Figure $1 \mathrm{~g}$ ). This design is present on a carinated bowl.

The one rim is from a plain carinated bowl (Figure 1a). The bowl has a direct and standing rim (Table 5).

\section{LITHIC ARTIFACTS}

The lithic artifact assemblage from the site consists primarily of lithic debitage, cores, and bifacial tools (Table 1). A few unifacially worked flake tools are present, while the remainder of the lithic tools include an arrowpoint, and a small fragment of a polished axe.

The majority of the lithic debitage and tools are on Ogallala chert, followed by quartzite, and other types of chert (Table 6). With few exceptions, these lithic raw materials are locally available in upland stream divides and ridges as gravels of palm and fist-sized cobbles (Bruseth and Perttula 1981:Table 6-7). Quartzite and ferruginous sandstone also occur in outcrops of Eocene age Weches and Reklaw formations in the Upper Sabine Basin (Perttula et al 1986:449).

The unmodified lithic debitage from 41RA65 has been categorized following the method of debitage analysis formulated by Sullivan and Rozen (1985:Figure 2). This approach differs from others employed in East Texas because it is based on dimensions of flake margins, positive percusion features, and the presence of a point of applied force (i.e. presence of a striking platform) that can

Table 6

\section{LITHIC RAW Material UtLLZATION AT 41RA65}

\begin{tabular}{|c|c|c|c|c|c|c|}
\hline \multirow{2}{*}{$\begin{array}{l}\text { Artifact } \\
\text { Class }\end{array}$} & \multicolumn{5}{|c|}{ Percentage of } & \multirow{2}{*}{$\begin{array}{c}\text { Total } \\
\text { Number }\end{array}$} \\
\hline & $\mathrm{Q}^{*}$ & 0 & PW & $\mathrm{C}$ & FS & \\
\hline Lithic debitage & 14.8 & 62.6 & 2.6 & 18.1 & 1.9 & 270 \\
\hline Cores & & 88.9 & & 11.1 & & 9 \\
\hline Thick bifaces & 57.1 & 42.9 & & & & 7 \\
\hline Thin bifaces & 25.0 & 41.7 & 16.7 & 16.7 & & 12 \\
\hline $\mathrm{PP} / \mathrm{K}$ & 33.3 & 66.7 & & & & 6 \\
\hline Arrowpoint & & 100.0 & & & & 1 \\
\hline Utilized pieces & & 53.8 & & 46.2 & & 13 \\
\hline Axe fragment & & & & & 100.0 & 1 \\
\hline $\begin{array}{l}\text { Fire cracked } \\
\text { rock }\end{array}$ & 77.8 & 22.2 & & & & 9 \\
\hline Summary & 17.1 & 63.1 & 2.7 & 152 & 18 & 328 \\
\hline
\end{tabular}

- $Q=$ Quartzite, $O=$ Ogallala Chert, $P W=$ Petrified Wood, $\mathrm{C}=$ Chert $\mathrm{FS}=$ Ferruginous Sandstone 


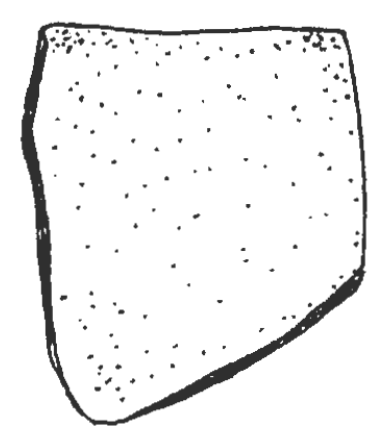

A
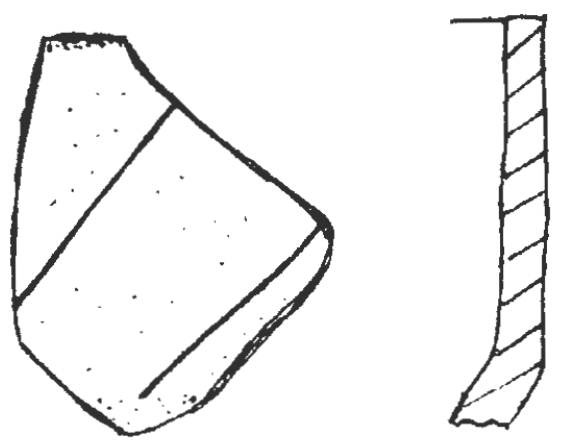

C

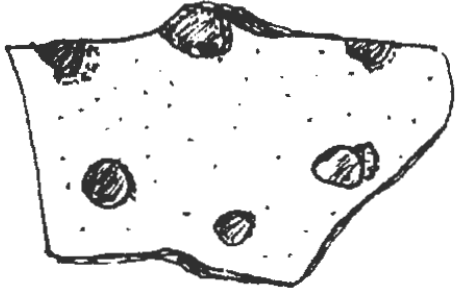

F
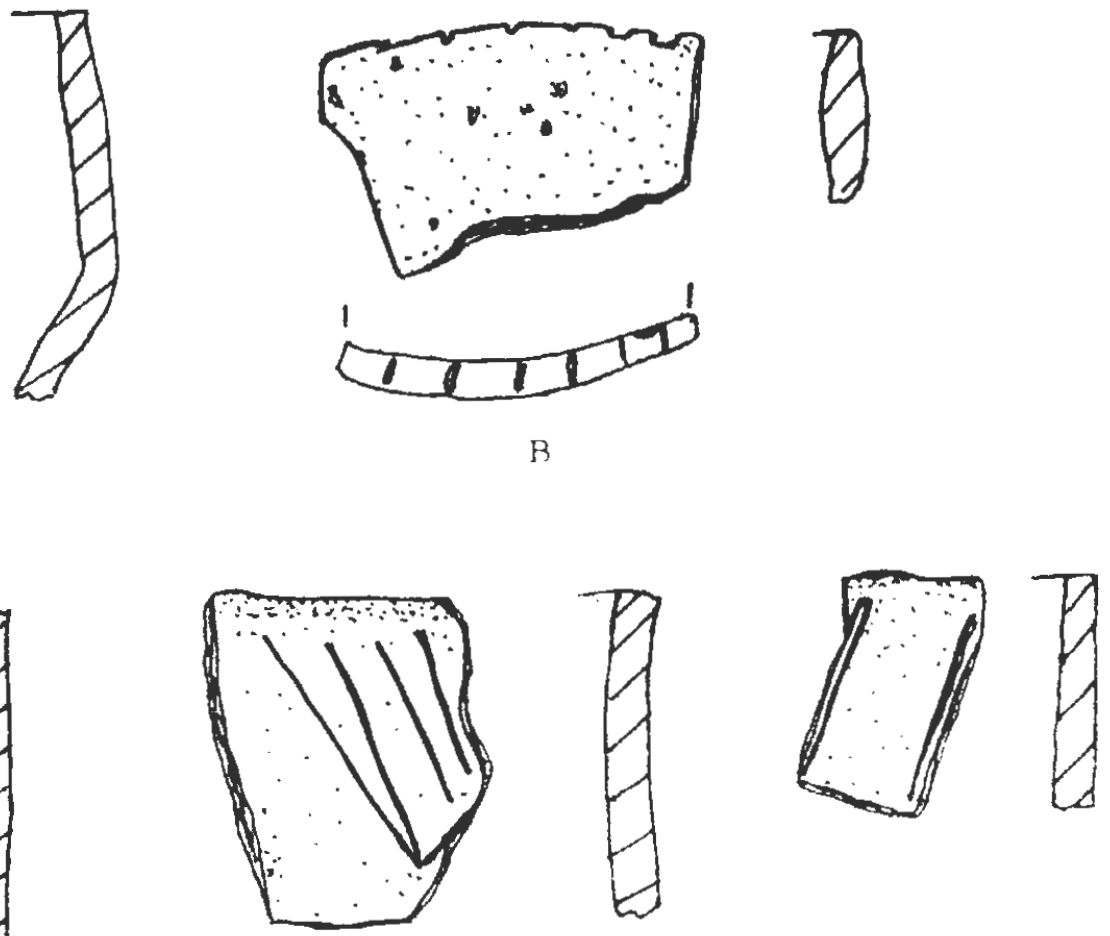

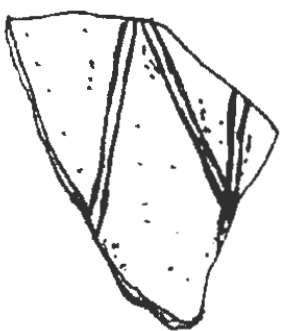

$\mathrm{H}$

Figure 1. Decorated ceramics and rim sherds from 41RA65: A - Groglbone tempered rim from a plain carinated bowl. B - Grog tempered scalloped rim from simple bowl. Lip of rim is decorated with lncised lines. C - Grog-grit tempered rim with diagonal engraved lines. Vessel is a carinated bowl. $D$. Groglbone tempered rim wilh engraved lines. Decorative motif is a triangle filled with diagonal llnes. E - Grog tempered rim decorated with diagonal incised lines. $F$ - Grog-grit tempered body sherd decorated with large punctallons. $G$ - Grog-grit tempered body sherd decorated with rows of punctations. Vessel is a carinated bowl. $H$ - Grog gril tempered body sherd from an incised bowl. The decorative mollf is cross-hatched incised line. Note: All artifacts are Illustrated actual size. 
be assessed independently of hypothetical reduction sequences or particular methods of tool production (Sullivan and Rozen 1985:758). Categories recognized include complete flakes, broken flakes, flake fragments, and debris (Table 7).

Table 7

Raw Materials and Flake Types

\begin{tabular}{|c|c|c|c|c|c|c|c|}
\hline \multirow[b]{2}{*}{ Flake Type } & \multirow[b]{2}{*}{ Number } & \multirow[b]{2}{*}{$\mathrm{Q}^{*}$} & \multicolumn{3}{|c|}{ Percentage of } & \multirow[b]{2}{*}{ FS } & \multirow{2}{*}{$\begin{array}{l}\text { Percen } \\
\text { Cortica }\end{array}$} \\
\hline & & & 0 & & $\mathrm{C}$ & & \\
\hline Complete & 28 & 18 & 32 & 4 & 46 & & 50.0 \\
\hline Broken & 42 & 12 & 62 & & 21 & 5 & 35.7 \\
\hline Fragments & 62 & 13 & 57 & & 29 & 2 & 43.5 \\
\hline Debris & 138 & 16 & 72 & 4 & 7 & 1 & 43.5 \\
\hline Summary & 270 & 15 & 63 & 3 & 18 & 2 & 43.0 \\
\hline
\end{tabular}

- $Q=$ Quartzite, $O=$ Ogallala Chert, $P W=$ Petrified Wood, $C=$ Chert, FS = Ferruginous Sandstone

The largest category of flake type in the assemblage is debris, lithic artifacts lacking a striking platform, a bulb of percussion, and with margins that are not intact. These artifacts are generally small in size, and analogous to the term chip used in some East Texas typologies. Debris accounts for $51.1 \%$ of the debitage in the assemblage, followed by flake fragments, broken flakes, and complete flakes (Table 7).

There is little difference between flake types and the percentage of flakes with cortex, indication that the different kinds of flakes were produced as part of the overall process of tool and core reduction carried out on the site. The high proportion of debris, flake fragments, and broken flakes at 41RA65 also suggest that both tool manufacture and core reduction activities were important lithic technological activities. This is further attested to by the frequency of cores, and broken bifaces that are discarded manufacturing failures. The comparability in proportions of cortical debitage among the four flake types would be expected in a lithic technology where cobbles and partially cortical cores were specifically reduced in order to produce useable, complete flakes for tools. This interpretation seems to be supported if one notes the high relative frequency of complete chert flakes in the lithic debitage (Table 7), and the percentage of complete flakes classified as utilized pieces (Table 8). Complete flakes are two to five times more likely to be selected for use as tools than the other types of flakes in the 41RA65 assemblage.

The utilized pieces constitute a morphologically diverse set of flake tools, ranging from those exhibiting a few small continous flake scars along lateral and/or distal
Table 8

\section{Utilized Pieces, Raw Materials, FLAKE TYPES}

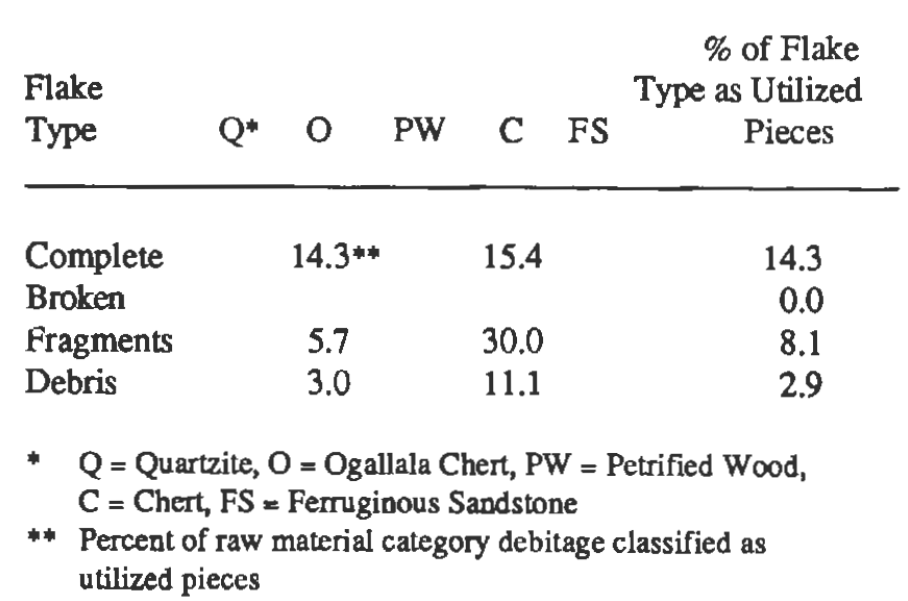

edges (Figure $2 \mathrm{~h}, \mathrm{i}$ ) to those where retouched flake scars are more uniform, larger in size, and continous along the margins of the tool (Figure $2 \mathrm{~g}$ ). In the latter case, the uniform flake removals imply more extensive use and/or intentional retouching of the tools.

The one arrow point from 41RA65 (Figure 2a) has a contracting stem, straight-concave blades, and distinct, slightly barbed shoulders. It is similar to Form 2 arrow points defined at Lake Fork Reservoir (Bruseth and Perttula 1981:Figure 6-1), and to the Minter type identified by Johnson (1962:250). In both cases, these contracting stem arrow points occur on archaeological sites dating after A.D. 800 , but probably before ca. A.D. 1400.

Two of the projectile point/knives $(\mathrm{PP} / \mathrm{K})$ were manufactured of a coarse grained, non-heat treated, red quartzite, while the others were made of locally available Ogallala chert. All of the PP/K are classified as the Gary type, var. Camden (Schambach 1982). Schambach defined three varieties of Gary points - var. Camden, var. LeFlore, and var. Gary - that represent modal trends in thickness and stem width which have chronological implications. The var. Camden Gary points are the thinnest, and have the narrowest stem width of the three varieties, and are considered the latest expression of the type. Schambach's findings are summarized in Table 9. The modal stem width of $1.4 \mathrm{~cm}$, and modal thickness of $0.6 \mathrm{~cm}$, in the small sample of Gary points from 41RA65 is generally consistent with the metrical parameters of the var. Camden (Table 9). Moreover, its presence is contextually appropriate for an Early Ceramic Period component at the site.

Based on attributes of blade asymmetry, serration (Figure 2d), and beveling (Figure 2c) it is clear that these $\mathrm{PP} / \mathrm{K}$ were continually laterally resharpened while still at- 

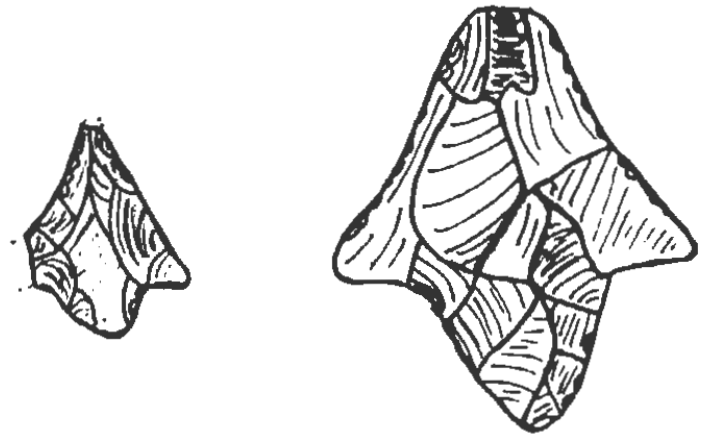

B,

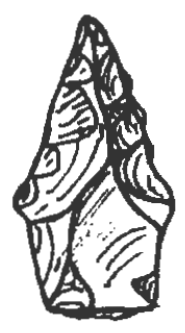

D

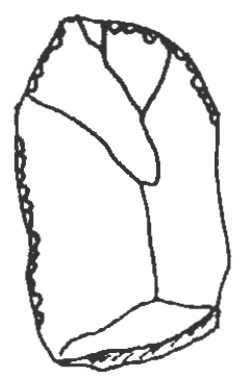

Fi

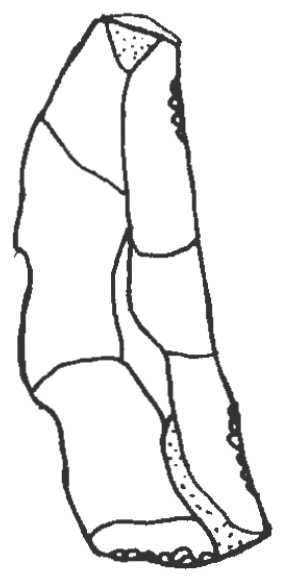

$\mathrm{H}$

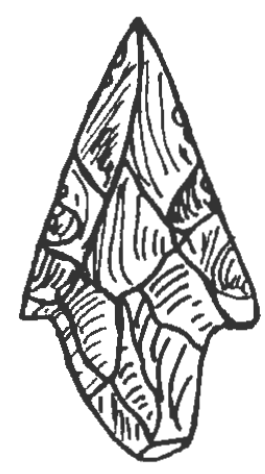

C.

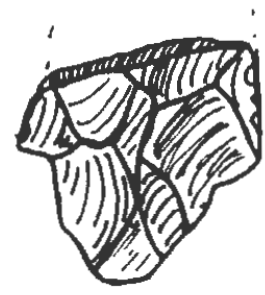

F

Figure 2. Arrow points, dart points, and utilized pieces. A - Contracting stem arrow point manufactured on Ogallala chert. $B \cdot D, F$. Gary var. Camden projectile points of Ogallala chert. E - Gary var. Camden projectile point of red quartzile. G-I - Utilized pieces on complete flakes. 
Table 9

\section{DifFerences Between Gary Points*}

\begin{tabular}{lccc}
\hline Varieties & $\begin{array}{c}\text { Thickness } \\
\text { (mode) }\end{array}$ & $\begin{array}{c}\text { Stem Width } \\
\text { (mode) }\end{array}$ & $\begin{array}{c}\text { Temporal } \\
\text { Span }\end{array}$ \\
\hline
\end{tabular}

$\begin{array}{lccc}\text { Camden } & 0.7^{* *} & 1.4 & 1700-1200 \text { B.P. } \\ \text { LeFlore } & 0.7-0.8 & 1.6-1.7 & 2400-1700 \text { B.P. } \\ \text { Gary } & 1.0-1.1 & 2.2-2.3 & 2800-2400 \text { B.P. }\end{array}$

* From Schambach 1982:Table 7.2, 7.4

* In centimeters

tached to a foreshaft. Evidence of edge crushing and step fractures on the lateral margins suggests these implements were used in cutting and scraping tasks. The presence of impact fractures on two of the specimens (see Figure 2b) also indicates the tools were used as projectiles; the Gary PP/K is truly a multi-purpose tool.

Ovoid to triangular bifaces are common at 41RA65. These bifaces range from pieces without well defined working edges and/or zones of utilization on edges or faces (thick bifaces) to those with regular shapes and well defined working edges across the tool. Of the latter (thin bifaces), eight of twelve are fragmentary pieces that were apparently broken during final manufacture. Wear pattems are identifiable on several specimens (though wear patterns are difficult to observe on the coarse grained quartizites collected in local gravels), primarily low to medium angle unifacial flaking (Bruseth and Perttula 1981:Table 6-5). Items included within this class represent both completed, but fragmentary, bifacial tools, and bifaces that are preforms which have not yet been proximally modified for hafting. In general, thin bifaces are manufacturing by-products in the production of PP/K.

The thick bifaces are not finished tools. They represent instead initial attempts in the reduction of cobble-sized pieces of raw material, for the eventual production of $\mathrm{PP} / \mathrm{K}$, that were discarded before substantial thinning could be accomplished. Knapping failures, raw material inclusions, and poor quality raw materials all are contributing factors in these thick bifaces not being completed. Cortex remnants on the thick bifaces also suggest that pieces of raw material were small in size, ranging from $4-10 \mathrm{~cm}$ in length and $3-6 \mathrm{~cm}$ in width. The cores from 41RA65 are generally about the same size, and hardly suitable for the production of large tools, but flakes for unifacial tools, arrow points, and some of the $\mathrm{PP} / \mathrm{K}$ are possible to manufacture with cobbles of these size ranges.

While both thin and thick flakes are uniformly manufactured from local upland gravels (Table 6), one thin biface of a distinctive white chert was noted. This white chert, which has macroscopically visible black inclusions, resembles Frisco chert from the Arbuckle Mountains in Southeastern Oklahoma (Banks 1984), but its specific origin has not been traced as yet. This lithic raw material has been noted at a number of prehistoric sites in the Upper Sabine Basin, albeit in an Archaic context (Perttula et al. 1986). Cherts from the Arbuckle Mountains region were noted also in Lake Fork Reservoir sites dating from ca. 4000 - 400 B.P., but this non-1ocal material was not as common as raw materials from the Edwards Plateau or the Ouachita Mountains (Bruseth and Perttula 1981:Table 6-10).

A total of nine cores were recovered from the surface collection at 41RA65. Eight of the cores are of Ogallala chert, and one is a black chert similar to the black variety of Big Fork chert (Mallouf 1976:49-50). The nearest source of Big Fork chert is in Red River gravels below the Kiamichi River confluence in the vicinity of the Sam Kaufman Site (Skinner et al. 1969). This particular core is a small river cobble, $3 \mathrm{~cm}$ in length and width, with gravel cortex covering approximately $50 \%$ of the cobble. The cores definitely of local chert were collected and brought to the site where initial to final manufacturing took place. Flakes have been removed from unprepared platforms, whether single, multiple, or opposed in orientation. None of the cores have been depleted since gravel cortex is visible on both the dorsal and ventral surfaces of the cobbles, but because of their small size it would be difficult to remove many additional flakes to thin the cobble without actually splitting the cobble inadvertently. One of the cores actually represents a substantial remnant of a split and fractured core.

One fragment of a polished axe was found at 41RA65. The axe was manufactured from a locally available fernginous sandstone.

Quartzite and chert cobbles were also utilized in cooking activities. Nine rocks from the surface collection (Table 6) show evidence of heating sufficient to have fractured the cobbles from exposure to a heat source.

\section{TEMPORAL AND FUNCTIONAL CONTEXT}

No radiocarbon dates have been obtained from 41RA65. Based on the styles of the $\mathrm{PP} / \mathrm{K}$ and the ceramic wares recovered from the disturbed surface of the site it is apparent that the site was occupied during both the Early Ceramic and Early Caddoan Periods.

The Early Ceramic Period in the Upper Sabine Basin, as well as in East Texas generally, is poorly known at present (Perttula et al. 1986:53-54). It represents a particularly important cultural expression, however, because it bridges the gap in time between non-sedentary hunter-gatherers and the evolution of sedentary horticulturists in the region (e.g. Story 1985). Within the Upper Sabine Basin components belonging to this time period have been identified at several sites, including an 
Early Ceramic midden excavated at the Resch Site (Webb et al. 1969), a small component at the Yarbrough Site, Area A (see Johnson 1962:206), and six components at Lake Fork Reservoir (Bruseth and Perttula 1981).

None of the components at Lake Fork contained Williams Plain ceramics, the thick grog tempered ware usually considered a diagnostic for the Early Ceramic Period. Additionally, several components are suspected to date after ca. A.D. 500 because of the presence of Friley arrow points, other arrow points, and ceramic assemblages dominated by horizontally incised decorative motifs confined to vessel rims. A date of A.D. $775 \pm 68$ from the Osborn Site was the only radiocarbon date obtained from the Early Ceramic components. The Osborn occupation probably marks one of the latest Early Ceramic components (Bruseth and Perttula 1981:141), or one of the earliest Early Caddoan Period I occupations, in the reservoir. A re-examination of the cultural content of the Early Ceramic assemblages from Lake Fork suggest that based on temporal and stylistic groups, components of the period recognized there overlap with both Early Ceramic and Early Caddoan Period I assemblages defined elsewhere in East Texas (Thurmond 1981, 1985).

The Early Ceramic component at 41RA65 is estimated to date from ca. A.D. 200 - 700, based primarily on the occurrence of Gary var. Camden $P P / K$. Associated with these tools is a lithic artifact assemblage not significantly different from that of the local Late Archaic in that it is dominated by bifacial cutting and scraping tools and quantities of cores. The frequencies of bifaces, cores, and PP/K in Late Archaic and Early Ceramic assemblages at Lake Fork Reservoir are quite different from Early and Late Caddoan assemblages (Bruseth and Perttula 1981:Table 6-4). It is suspected that the majority of the bifacial tools, cores, and debitage are associated with the Early Ceramic occupation, rather than with the Early Caddoan settlement at 4IRA65. Certainly, the predominate utilization of locally available lithic raw materials such as Ogallala chert, petrified wood, and quartzite is consistent with the Early Ceramic pattern of lithic raw material use noted in Lake Fork Reservoir (Bruseth and Perttula 1981:Table 6-9). The utilization of non-local materials for tool manufacture was found to be quite low in Early Ceramic Period lithic assemblages, about three to six times lower than in Early Caddoan sites. Early Ceramic groups employed local materials in such high frequencies due in part to territorial constraints, reductions in exploitation range, and localized interregional exchange (Perttula 1984).

The lithic assemblage recovered would seem to suggest that one of the primary activities at the site during the Early Ceramic occupation includes lithic tool production and maintenance, hunting, butchering and cutting of meat products, and some plant food processing. Cooking and storage of plant and animal foods are indicated by the use of ceramic containers, as well as by the presence of fire cracked rock.
While the midden deposits at 41RA65 probably date primarily to the Early Caddoan Period, Early Ceramic settlements in the Upper Sabine Basin do have earthen middens. At the Howle, Block I (41WD74), and Osborn Early Ceramic components earthen middens were present with storage and trash pits, and other indications of relatively permanent multi-seasonal occupations. These types of occupations have been interpreted as singlefamily homesteads occupied for one to two generations (Bruseth and Perttula 1981:141). With only limited evidence on settlement available from 41RA65 we are hesitant to ascribe to it a particular settlement type or function. This is an analytical effort that requires extensive archaeological investigations and regional landuse information.

In the Early Caddoan occupation of the Upper Sabine Basin the most common types of settlement are locales containing one to three middens per site. These middens represent small habitation areas of fairly brief occupational span: perhaps 50 - 100 years if the chronological record from the Taddlock Site, a well preserved example of such sites, is accurate. Three radiocarbon dates from Taddlock document an occupation dating from A.D. $1037 \pm 74$ to A.D. $1070 \pm 77$ (Bruseth and Perttula 1981:48-53). The middens have been found either to cover house locations or represent concentrated trash deposits of broken ceramic vessels, bones, plant remains, and other refuse. Because of the fact that the midden deposits at 41RA65 were disturbed, there seemcd little way to determine its nature without designing an excavation program to look for subsurface features and in silu cultural remains on the site. Since the midden appeared to have been relatively large it is probable that a large part of it is composed of sheet trash dispersed across the flatter parts of the landform, though domestic structures were likely present at the site.

Early Caddoan midden sites in the Upper Sabine Basin are usually classified as sedentary hamlets and farmsteads. Not only are they located near arable soils, but flotation of midden deposits at a number of sites have documented that maize (Zea mays L.) is ubiquitous, even though other wild plant foods were also important parts of the economy (Perttula et al. 1983). In addition to nuts and maize, seeds from 15 wild plant species were recovered in flotation samples from the Early Caddoan component at the Spoonbill Site, about $20 \mathrm{~km}$ east of 41RA65.

The Early Caddoan settlement at 41RA65 took place about $650-800$ years ago, ca. A.D. $1150-1300$. The presence of Sanders Engraved, Sanders Plain, scalloped rim bowls, and Canton Incised in the ceramic assemblage seems congruent with this general placement, though a temporal estimate of ca. A.D. 1200 - 1400 could be entertained (e.g. Thurmond 1985:189). Our suggested chronological context for the settlement at 41RA65 is founded primarily on a proposed seriation of radiocarbon dated Early Ceramic and Early Caddoan component design elements from Lake Fork Reservoir sites (see Bruseth and 
Perttula 1981:Table 5-9). Of particular interest are changes in the relative proportions of Canton Incised, Davis Incised, Sanders Engraved, and punctated designs (Table 10). The admittedly small ceramic sample from 41RA65 is placed in the seriation between the Hines Site (41WD450) and the Spoonbill Site, Early Caddoan occupations with house construction features and other evidence for permanent settlement (Bruseth and Perttula 1981:21-26, 40-48).
Caddoan components investigated at Lake Fork Reservoir (Bruseth and Perttula 1981:Table 8-1).

\section{CONCLUSIONS}

While the Lake Fork Creek area has been the scene of relatively intense archaeological investigations since the mid-1970s it is fair to say that the regional archaeological

Table 10

\section{Proposed Seriation of Selected Early Ceramic and Earl y Caddoan Components AT LAKE FORK RESERVOIR}

\begin{tabular}{llcrcr}
\hline Component & $\begin{array}{l}\text { Temporal } \\
\text { Context* }\end{array}$ & $\begin{array}{c}\text { Canton } \\
\text { Incised }\end{array}$ & $\begin{array}{c}\text { Davis } \\
\text { Incised }\end{array}$ & $\begin{array}{c}\text { Sanders } \\
\text { Engraved }\end{array}$ & Punctated \\
\hline Osborn, A & A.D. $557 \pm 68$ & $47^{* *}$ & 11 & 12 & 30 \\
Taddlock, A & A.D. $1037 \pm 74$ & 54 & 2 & 24 & 19 \\
& A.D. $1060 \pm 77$ & & & & \\
Hines, A & A.D. $1070 \pm 77$ & & & 28 & \\
41RA65 & A.D. $1130 \pm 55$ & 57 & & 27 & 2 \\
Spoonbill & A.D. $1047 \pm 91$ & 64 & & & \\
& A.D. $1070 \pm 77$ & 70 & & & \\
& A.D. $1290 \pm 55$ & A.D. $1295 \pm 27$ & & &
\end{tabular}

* Corrected radiocarbon dates, 1 standard deviation (Klein et al. 1982)

** Percentage

There are two Early Caddoan components at Spoonbill, but the most intensive occupation is the one radiocarbon dated at A.D. $1290 \pm 55$ and A.D. $1295 \pm$ 27. This component can be classified as an Early Caddoan Period II Sanders phase occupation. Thermoluminescence dates of ca. A.D. 1280 (Alpha-2398) and A.D. $1400 \pm 60$ (Alpha-2397) from Sanders phase components in the Big Sandy Creek valley in Wood County (Perttula et al. 1986:484) support the Spoonbill dates.

The Hines and Spoonbill dates effectively bracket the period between ca. A.D. $1150-1300$ as the span of time in the Early Caddoan Period I/II when it is most likely that 41RA65 was occupied. It is doubtful, however, that the site was continously occupied throughout that period. Instead, any one Early Caddoan settlement at the site was probably of short duration, though we have no concrete evidence that the site was sequentially re-occupied within the Early Caddoan Period. We suggest the possibility of multiple occupations from the fact that the midden deposits are fairly extensive compared to other Early record is structured more in terms of basic-temporal spatial analyses than it is to broader conceptualizations of cultural change. That is not to suggest that advances in processual studies, i.e. questions concerning settlement pattern types, subsistence, and models of cultural systems, have not taken place in the area, or in the Upper Sabine Basin in general. Rather, significant information on the diversity and variability in the regional archaeological record, particularly for the Caddoan sequence, has - been obtained here that is quite comparable to important developments elsewhere in East Texas and the Caddoan Area. Future prospects are exciting. At the same time, we are faced with relatively pedestrian, but integral, questions of chronological context because of a poorly developed sequence of radiocarbon dates, as well as from an overall lack of interest in refining chronological problems (Thurmond 1985:188). The need for chronological control is still a critical parameter in developing a more systematic understanding of prehistoric adaptations in East Texas 
since a local chronology is necessary if questions about cultural change are to be addressed. Our concem with process must be tempered with this grounding in chronology; the study of Caddoan archaeology needs to proceed simultaneously at both levels.

In this paper we have endeavored to present information on site assemblage character and age from a multi-component Early Ceramic and Early Caddoan settlement in the Upper Sabine Basin. The site is not pristine, far from it, but we believe that the site contains data of local and regional importance. This is especially so because of the continuing research emphas is on changing land use in East Texas and the Upper Sabine Basin (e.g. Bruseth and Perttula 1981; Thurmond 1981). Construction and development activities associated with the impoundment of waters for the Lake Fork Reservoir unfortunately led to major disturbances at the site. 41 RA65 was known from earlier surveys; it is a moot point now as to whether or not the site warranted additional investigations before construction activities and inundation proceeded. However, we believe that the continued study of such unprotected sites as 41RA65 is essential in the Upper Sabine Basin. Without further work at sites of these time periods and character, a full understanding of settlement and land use through time will not be possible before further development activities permanently destroy the archaeological record of the region.

Acknowledgements: We wish to thank Paul $M c G u f f$ for his editorial assistance, though we remain responsible for the contents of the paper.

\section{REFERENCES}

\section{Banks, L. P.}

1984 Lithic Resources and Quarries. In Prehistory of Oklahoma, edited by R. E. Bell, pp. 65-95. Academic Press, New York.

Brown, J. A.

1971 Spiro Studies: Pottery Vessels. Vol. 3. Research Institute, University of Oklahoma, Norman.

Bruseth, J. E., J. T. Bagot, K. M. Banks, and M. A. McKinley

1977 Archaeological Research at Lake Fork Reservoir: Site Inventory and Assessment. Research Report No. 87. Archaeology Research Program, Southern Methodist University, Dallas.

Bruseth, J. E., and T. K. Perttula

1981 Prehistoric Settlement Patterns at Lake Fork Reservoir. Texas Antiquities Permit Series, Report No. 2. Texas Antiquities Committeee, Austin, and Southem Methodist Universtiy, Dallas.
Duffield, L. F.

1961 The Limerick Site at Iron Bridge Reservoir, Rains County, Texas. Bulletin of the Texas Archeological Society 30:51-116.

Ferring, C. R., and T. K. Perttula

n.d. Petrographic Studies of Sanders Plain, an Early Caddoan Ceramic Ware. MS in preparation.

Jelks, E. B. (editor)

1967 The Gilbert Site, a Norteno Focus Site in Northeastern Texas. Bulletin of the Texas Archeological Society 37: 1-248.

Johnson, L., Jr.

1962 The Yarbrough and Miller Sites of Northeastern Texas, with a Preliminary Definition of the LaHarpe Aspect. Bulletin of the Texas Archeological Society 32:141-284.

Jones, B. C.

1957 The Grace Creek Sites, Gregg County, Texas. Bulletin of the Texas Archeolngical Societ 28:198-231.

Klein, J., J. C. Lerman, P. E. Damon, and E. K. Ralph 1982 Calibration of Radiocarbon Dates: Tables Basec on the Consensus Data of the Workshop on Calibrating the Radiocarbon Time Scaie. Radiocarbon 24(4):103-150.

Krieger, A. D.

1946 Culture Complexes and Chronology in Northern Texas. Publication 4640. The University of Texas at Austin.

Lane, G. L.

1977 Soil Survey of Hopkins and Rains Counties. Texas. United States Department of Agriculture, Soil Conservation Service in cooperation with the Texas Agricultural Experimental Station.

Mallouf, R. J.

1976 Archeological Investigations at Proposed Big Pine Lake, 1974-1975, Lamar and Red River Counties, Texas. Archeological Survey Report No. 18. Texas Historical Commission, Austin.

Perttula, T. K.

1984 Pattens of Prehistoric Lithic Raw Material Utilization in the Caddoan Area: The Westem Gulf Coastal Plain. In Prehistoric Chert Exploitation Studies from the Midcontient, edited by $\mathrm{B}$. M. Butler and E. E. May, pp. 120-148. Occasional Paper 2. Center for Archaeological Investigations, Southern Illinois University-Carbondale.

Perttula, T. K., C. J. Crane, and J. E. Bruseth 
1983 A Consideration of Caddoan Subsistence. Southeastern Archaeology 1:89-102.

Perttula, T. K., B. D. Skiles, M. B. Collins, M. C. Trachte, and F. Valdez

1986 "This Everlasting Sand Bed": Cultural Resources Investigations at the Texas Big Sandy Project, Wood and Upshur Counties, Texas. Reports of Investigations No. 52. Prewitt and Associates, Inc., Austin.

Rogers, J. D., S. Gough, and D. Heffington 1985 Temper Quantification and Identification in Prehistoric Ceramics. Bulletin of the Oklahoma Anthropological Society 34:83-95.

Rohrbaugh, C. L.

1985 LfGeI, The Geren Site, 34LF36, of the Spiro Phase. Bulletin of the Oklahoma Anthropological Society 34:981.

Schambach, F. F.

1982 An Outline of Fouche Maline Culture in Southwest Arkansas. In Arkansas Archaeology in Review, edited by N. L. Trubowitz and M. D. Jeter, pp. 132-197. Research Series No. 15. Arkansas Archaeological Survey, Fayetteville.

Sheperd, A. O.

1976 Ceramics for the Archaeologist. Carnegie Institution of Washington, Publication 609. Washington, D. C.

Skinner, S. A., R. K. Harris, and K. M. Anderson 1969 Archaeological Investigations at the Sam Kaufman Site, Red River County, Texas. Southern Methodist Universtiy, Contributions in Anthropology, No. 5. Dallas.

Story, D. A.

1981 An Overview of the Archaeology of East Texas. Plains Anthropologist 26:139-156.
1985 Adaptive Strategies of Archaic Cultures of the West Gulf Coast Plain. In Prehistoric Food Production in North America, edited by R. I. Ford, pp, 19-56. Anthropological Papers No. 75. Museum of Anthropology, University of Michigan, Ann Arbor.

Suhm, D. A., and E. B. Jelks

1962 Handbook of Texas Archeology: Type Descriptions. Texas Archeological Society Special Publication 1 and Texas Memorial Museum Bulletin 4, Austin.

Sullivan, A. P. and K. C. Rozen

1985 Debitage Analysis and Archaeological Interpretation. American Antiquity 50:755-779.

Thurmond, J. P.

1981 Archeology of the Cypress Creek Drainage Basin, Northeastern Texas and Northwestern Louisiana. Master's thesis, Department of Anthropology, The Unviersity of Texas at Austin.

1985 Late Caddoan Social Group Identifications and Sociopolitical Organization in the Upper Cypress Basin and Vicinity, Northeastern Texas. Bulletin of the Texas Archeological Society 54:185-200.

Webb, C. H., F. E. Murphey, W. G. Ellis, and H. R. Green

1969 The Resch Site, 41HS16, Harrington County, Texas. Bulletin of the Texas Archeological Society 40:3-106.

Williams, S., and J. P. Brain

1983 Excavations at the Lake George Site, Yazoo County, Mississippi, 1958-1960. Papers of the Peabody Museum of Archaeology and Ethnology No. 74. Harvard Universtiy, Cambridge, Massachusetts. 


\title{
EARLY CADDOAN SUBSISTENCE STRATEGIES, SABINE RIVER BASIN, EAST TEXAS
}

\author{
by
}

Timothy K. Perttula and James E. Bruseth

\begin{abstract}
Well preserved faunal and floral materials recovered from the Taddlock and Spoonbill sites in the Sabine River Basin of East Texas provide one of the first opportunities to document the subsistence strategies of sedentary hamlet occupations during the Early Caddoan period. The Taddlock site, dated ca. A.D. $940-1000$, has a large faunal assemblage indicating a generalized and balanced exploitation of small and large mammals, reptiles, and fish. The two components at Spoonbill, dated ca. A.D. $970 \pm 65$ and A.D. $1260 \pm 65$, are characterized by an extensive floral sample of wild plant foods, seeds, and maize. At both sites, maize constitutes less than $10 \%$ by weight of the total plant food remains. The Early Caddoan inhabitants exploited a wide variety of animal and plant food, but at this time maize was likely one of several main sources of food energy rather than the focus of a specialized economy.
\end{abstract}

\section{INTRODUCTION}

Because faunal and floral preservation is generally poor in the acidic soils of East Texas, the consideration and interpretation of prehistoric subsistence patterns in this region of the Caddoan area rests more on the available ethnographic information than on the archaeological record itself. Excavations at the Taddlock (X41WD39) and Spoonbill (41WD109) sites in Wood County on Lake Fork Creek in the Upper Sabine River Basin produced well preserved and abundant faunal and floral remains from Early Caddoan period Sanders focus context (Krieger 1946). The material recovered from these two sites affords considerable insight into the nature of Early Caddoan subsistence at a time of funda- mental culture change in East Texas prehistory (Story 1981:149).

In this paper we document and explicate the subsistence strategies of sedentary hamlet occupations during the Early Caddoan period: first, by summarizing the faunal and floral data from the two sites, and second by comparing these sites with other published Caddoan sites of this and later periods.

THE SITES, NATURAL SETTING, AND CULTURAL BACKGROUND

The Taddlock and Spoonbill sites are located in the Oak-Hickory biotic association or Post Oak savannah in East Texas. This association is a narrow swath of woodland and is a natural transition zone between the more xeric Blackland Prairie to the west and the more mesic Oak-Hickory-Pine Forest or Pineywoods to the east (Fig. 1). Medium-tall to tall broadleaf deciduous forests characterize the Oak-Hickory forest association, with post oak and blackjack oak most common (Gould 1969). The Blackland Prairie to the west consists of medium-tall and dense little bluestem grassland (Küchler 1964:76). The Pineywoods to the east of the sites are similar to the Oak-Hickory forest with the exception that shortleaf and loblolly pine are also dominant species. The presence of pine is usually assumed to represent a subclimax or fire disclimax (Mahler 1973) and thus due to the less mature nature of the association.

The climate of the Upper Sabine River

Friends of Northeast Texas Archaeology, Special Publication No. 1 (1995) 


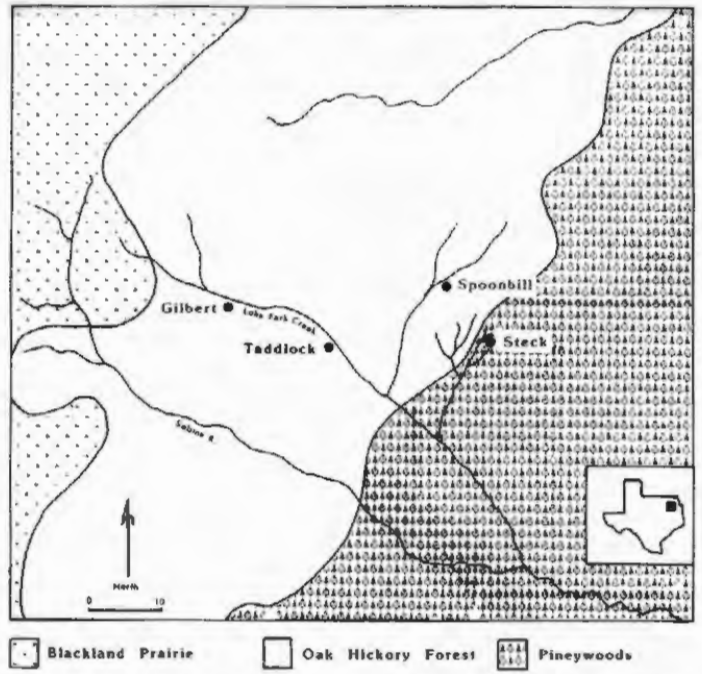

Fig. 1. Major biotic association in the Upper Sabine River Basin (after Küchler 1964) and sites mentioned in the text.

Basin is humid subtropical with average winter temperatures of $47^{\circ} \mathrm{F}$ and summer temperatures of $83^{\circ} \mathrm{F}$; droughts are not uncommon. Precipitation averages around 43 inches per year, with seasonal variations in amounts. The majority of precipitation falls in the spring and fall months. The growing season ranges over 230 days.

The Early Caddoan period in East Texas dates from ca. A.D. 750 to A.D. 1350 (Story and Valastro 1977). In the Upper Sabine River Basin, sites of this period are included in the recently defined Pecan Grove phase (Bruseth and Perttula 1981:141-142). Excavations at 16 components of this phase were conducted between 1975 and 1979, with extensive investigations primarily carried out at the Taddlock and Spoonbill sites in 1978 and 1979 (Bruseth et al. 1977; Bruseth and Perttula 1980, 1981).

Both sites apparently consist of a small number of house structures, a "plaza" between houses where features and activity areas are present, and adjacent trash middens or refuse pits with good to excellent ecofactual preservation. Pecan Grove phase settlements are present on both major and minor tributaries of the Sabine River and on the Sabine River itself (Skiles et al. 1980: Figure 5). Intra- and inter-site complexity during the Pecan Grove phase was minimal, with most sites either similar to Taddlock and Spoonbill in the nature of their occupation or apparently short-term, limited activity, sites scattered around the permanent settlements. This suggests that such sites represent the lowest level of regional Caddoan settlement and may be referred to as farmsteads (Story 1981:150). Four C-14 dates from Taddlock indicate an occupation dating from ca. A.D. 940 to A.D. 1000 , while five dates from Spoonbill in combination with associated artifact styles support components dated ca. A.D. $970 \pm 65$ and A.D. $1260 \pm 65$

\section{FAUNAL AND FLORAL ANALYSIS}

Excavation and analytical procedures at these two sites have been described elsewhere (Bruseth and Perttula 1981:11, 40-53, 117). Suffice it to state that all soil excavated was screened through 1/16 inch mesh, and uniform volumetric flotation samples were removed for processing from all excavation units, including general matrix and feature matrix. The flotation samples were processed by a watersluicing device (Bruseth and Carter 1980) that passed soil through four sizegraded screens: one heavy fraction grade: 2.0 $\mathrm{mm}$ mesh; and three light fraction grades: $1.68 \mathrm{~mm}, .707 \mathrm{~mm}$, and $.25 \mathrm{~mm}$ mesh (for the purposes of this paper all material separated by screen size has been combined; further details are on file at the Archaeology Research Program, Southern Methodist University).

Only the faunal material from Taddlock and the floral material from Spoonbill will be discussed in this paper. This is because only small quantities of floral material were recovered from Taddlock (summarized in Table 5 below), and less than 200 poorly preserved faunal elements were found at Spoonbill. It is unfortunate that complementary subsistence information could not be secured from each individual site, but the strong patterning between Taddlock and Spoonbill in the nature of the site occupation and topographic/environmental location support the comparative analysis of subsistence strategies during the Pecan Grove phase on the basis of the two partly contemporaneous sites.

A well preserved trash midden (Midden A) was excavated at the Taddlock site. A total of 63,463 faunal elements below the disturbed plowzone were recovered, primarily from the $1 / 16$ inch mesh residue. The majority 
of the thotation samples were not processed due to a shortage of funds, but several were examined which contained quantities of small elements such as fish vertebrae. Based on the $70 \%$ of the midden that was excavated, the total midden faunal content of $1 / 16$ inch material is estimated at 90,000 identifiable and unidentifiable elements. Faunal material is present at approximately 5,900 elements per cubic meter of cultural deposits.

Animals from all vertebrate classes are represented; mammals, reptiles, and fish were particularly important resources (Table 1). Those elements considered identifiable were classified to the lowest taxonomic level possible (see discussion in Butler and Perttula 1981:117).

Although mammal bones do not make up the largest portion of the sample, mammals were important to the site's inhabitants since they contributed proportionately a large amount of meat per animal (Table 2). Four mammals were most common: rabbit (eastern cottontail and swamp), jackrabbit, squirrel, and deer. These represent about $90 \%$ of the identified mammal sample.

White-tailed deer is the most frequent mammal species represented by element and certainly contributed the greatest quantity of meat to the diet, about $55 \%$ of the total estimated meat yield. The total number of deer elements at Taddlock is not, however, in the high proportion seen at other Caddoan sites (Byrd 1980; Doehner et al. 1978:Tables 53 and 54; Henderson 1978:Table 37). Based on dental wear, four age groups are represented: individuals between one and eleven months, $1 \frac{1}{2}$ to 2 years, 4 to 5 years, and 5 to 7 years old at the time of death. The sample is too small for quantitative interpretations of relative age distributions, but there is no evidence for preference of a certain age group (cf. Emerson 1980).

The abundance of smaller species, especially squirrels, jackrabbits, and rabbits, indicates a regional and/or local abundance in the Oak-Hickory savanna habitat. Over $80 \%$ of the Minimum Number of Individuals (MNI) for mammals are accounted for by the smaller species (less than $5 \mathrm{~kg}$ ). This suggests a low availability of larger species (Bayham 1979).

Of the birds from Taddlock, only the wild turkey is represented in quantity. Males were preferred, though females and juveniles are also present. Seven of the identified bird species are permanent East Texas residents, while the others, such as the pied-bill grebe, green-wing teal, and yellow-shafted flicker, all winter in East Texas and are there from approximately September to April.

The large number of turtle shell recovered indicates that turtles were an important economic resource. Both aquatic and land turtles were exploited, with the mud turtles and box turtles most frequent, but the snapping and slider turtles contributed the most meat to the diet (Table 2).

Several fish species were found at the site, all of which are common to rivers and streams of East Texas. The gar elements are either from shortnose or spotted gar and were probably collected in the summer through early fall after spawning. Bowfins like relatively clear, quiet waters with abundant aquatic vegetation and reach 15 pounds in weight (Byrd 1980:259). Both catfish and sunfish/bass can be found in a range of aquatic habitats, from small, clear streams to large rivers and sloughs (cf. Smith 1975:Table 14). These two species groups accounted for approximately $60 \%$ of the identifiable fish sample and about the same amount of meat as the suckers, the largest of the fish species represented in the Taddlock sample.

All of the species of animals recovered from Taddlock are either year-round or seasonal inhabitants of East Texas. The habitat range of species indicates that most animals were associated with an open OakHickory forest with many grassland areas. More extensive grassland areas were probably exploited for jackrabbits and prairiechickens. The forested bottomlands were exploited for various medium-sized mammals, as well as for birds. Fish were taken from Lake Fork Creek and its sloughs. The boundary or edge areas between the wooded bottomlands and the more open upland woods and grasslands were exploited for deer, terrestrial turtles, and wild turkey. Since these habitats are linear in orientation, with little wid th to each, most of the species of animals recovered from the site could have been procured within a relatively short distance of it.

The absence of three species at Taddlock, dog, bear, and bison, is notable given the historic utilization of these species by Caddoan peoples of East Texas (Swanton 1942: 
Table 1. Species Identified from the Taddlock Site Faunal Assemblege.

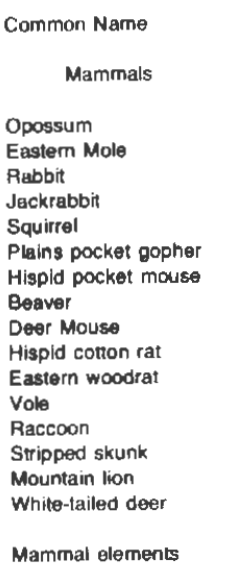

Birds

Pied-bill grebe
DuckJoose
Feal
Hawk
Turkey
Greater prairie chicken
Bobwhite
Barred owl
Yellow-shated flicker
Pileated woodpecker
Woodpecker
Crow
Perching birds

Bird elements

Reptiles

Snapping turtle

Mud turtle

Box turtle

Map turtie/Slider

Sohshell writie

Turte elements

Lizard

Snake

Snake

Snake elements

Amphibiens

Bullirog

Frog

Frog elements

Fish

Gar

Bawtin

Pickerel

Minnow

River carpsucker

Cattish

Sunfish/Bass

Freshwater drum

Fish elements

Craytian
Scientific Name

Didelphis virginiana

Scalopus aquaticus

Sylvilagus sp.

Lepus californicus

Sciurus sp.

Geomys bursarius

Perognathus hispidus

Castor canadensis

Peromygcus sp.

Sigmodon hispidus

Neotoma floridana

Microtus sp.

Procyon lotor

Mephitis mephitis

Folis concolar

Odocoileus virginianus

3461

Specres undentifiable

Podilymbus podiceps

Anetidee

Anes ct. carolinensis

Buteo sp.

Meleagrie gallopavo

Tympanuchus cupido

Colinus virginianus

Strix varia

Colaptes auratus

Dryocopus piteatus

Picidae

Corvus brachyrhynchos

Passerines

$\begin{array}{rr}70 & 8 \\ 5 & 2 \\ 236 & 9 \\ 275 & 13 \\ 487 & 21 \\ 82 & 8 \\ 2 & 1 \\ 2 & 1 \\ 7 & 2 \\ 12 & 3 \\ 11 & 3 \\ 4 & 2 \\ 19 & 3 \\ 5 & 2 \\ 1 & 1 \\ 1159 & 10\end{array}$

Species unidentifiable

40

Chelydra serpentina

Kinosternon/Stemothens sp

Terrepene sp.

Graptemys/Chrysemys spp.

Trionyx sp.

Species unidentiflable

1084

215

(gaunidae

Colubridee

Viperidae

Species unidentitiable

Pana catesbelana

Rane sp.

Species unidentifiable

Lepisosteus cf. platostomus

Amia calva

Esox sp.

Cyprinidae

c1. Carpiodes carpio

Ictalurus sp.

Centrarchidae

Aplodinotus grunniens

Species unidentifiable

3169 
Table 2. Estimated Meat Weights at Midden A, Taddlock Site.

Common Name

Mammals

Opossum

Eastern mole

Rabbit

Jackrabbit

Squirrel

Plains pocket gopher

Hispid pocket mouse

Beave

Deer mouse

Cotton rat

Woodrat

Vole

Faccoon

Skunk

Mountain lion

Deer

Mammal Total

Birds

Pięd-bill grebe

Duck/Goose

Teal

Hawk

Turkey

Prairie Chicken

Bobwhite

Barred OwI

Yellow-shatted flicker

Pileated woodpecker

Woodpecker sp.

Crow

Perching birds

Bird Total

Amphibians and Peptiles

Bullfrog

Frog

Snapping turtle

Mud turtle

Box turtle

Map/Slider

Sottshell

Snake

Amphibian/Reptile

Total

Fish

Shornose gar

Bowfin

Pickerel

Minnow

Catfish

Sunfish/Bass

Drum

Sucker

Fish Total
MNI

Est. Meat Yield

Individual $(\mathrm{kg})^{*}$

3.86

0.09

0.91

0.16

$\top$
9.08
$T$

0.10

0.23

$\mathrm{T}$
$\mathbf{3 . 6 3}$

4.22

27.24

34.00

89

$\mathrm{T}$
0.454

0.23

0.91

3.86

0.68
$T$

0.91

$\mathrm{T}$

0.136

0.136
$T$

25

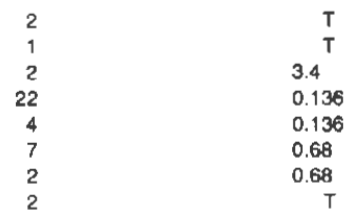

42

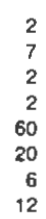

111

$0.454^{\cdots * *}$

$0.454^{* *}$

$T$

0.64

0.227

1.00

3.63
Species Meat

Yield (kg)

\% of Mest

Yield for

Class

6.2

1.6

2.5
3.8

$T^{0.3}$

1.8

T

$T^{0.1}$

2.2

1.7

72.8

100.0

469,04

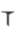

3.6

0.9

77.2

5.4

$\mathrm{T}$

$T^{3.6}$

1.6

$T^{0.5}$

100.0

25.00

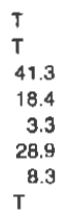

100.0

\begin{tabular}{cc}
$\mathbf{T}$ & \multicolumn{1}{c}{$\mathbf{T}$} \\
$\mathbf{T}$ & $\mathrm{T}$ \\
$\mathbf{8 . 8}$ & 41.3 \\
3.0 & 18.4 \\
0.54 & 3.3 \\
4.76 & 28.9 \\
1.36 & $\mathrm{8.3}$ \\
$\mathrm{T}$ & $\mathrm{T}$
\end{tabular}

16.46

0.9

3.

T

37.9

4.5

10.6

100.0

"Based on Smith (1975) and Smith (1978) for deer

${ }^{*}{ }^{*} T=$ Trace

-.Avereges of the values procented in Smlth (1975:Tables 33 and 34) 
134-137). The presence of dog at the nearby Steck (Fig. 1) and Arnold sites (a contemporaneous occupation $40 \mathrm{~km}$ to the north [Henderson 1978]), does show it was utilized in the region, at least for hunting purposes. Dog burials were common at these sites. Larger mammalian species with low reproductive rates, such as bear, do not seem to have been as frequently utilized during the Mississippian period in the southeastern United States as smaller species (Robison 1982), while bison was never very common in the East and North Texas prairies. In fact, it is only after ca. A.D. 1200 that bison populations seem to have increased in the Blackland Prairie to the west (Lynott 1980:99), or at least that different procurement strategies focusing on bison developed at that time (Ferring 1982). In any case, there is no evidence for the exploitation of bison in the Sabine Basin until the eighteenth century (Lorrain 1967:Table 11), even though the Blackland Prairie is only $25 \mathrm{~km}$ away as the crow flies from these sites.

At Taddlock, the wide and diverse range of species present shows the relative balance in which classes were utilized and a broadspectrum exploitation of the surrounding area. A diversity measure was utilized to quantify the variability in the faunal population: $A_{w}=1.00-S$. The diversity index $A_{w}$ is determined by summing the squared percentage of each variable (S), in this case classes mammals, birds, reptiles, and fish, and subtracting that number from 1.00. The resultant figure will range from 0.0 (homogenous population) to 1.00 (heterogenous population). Using the MNl of the different classes as the variables in the computations, a diversity index of 675 is obtained. This indicates a considerably heterogenous faunal population at the Taddlock site.

The intensity of animal groups exploited varied, however. Fish and turtle were intensively collected as were deer, squirrel, rabbits, and turkey. On the other hand, though many birds were locally available, including migratory fowl, their rarity suggests that they were not even important seasonal resources. Mammals contributed the greatest percentage of total meat to the Early Caddoan population at Taddlock (Table 3), with fish ranked second, followed by birds and amphibians/reptiles. Based on projected meat yields,
Table 3. Estimated Meat Yields, Taddlock Site

$\begin{array}{lrcr}\text { Class } & \text { MNI } & \begin{array}{c}\text { Estimated Meat } \\ \text { Yield }(\mathrm{kg})\end{array} & \begin{array}{r}\text { \% of Total } \\ \text { Meat Yield }\end{array} \\ \text { Mammals } & 89 & 469.04 & 76.6 \\ \begin{array}{l}\text { Birds } \\ \text { Amphibians/ }\end{array} & 25 & 25.00 & 4.1 \\ \begin{array}{l}\text { Reptiles } \\ \text { Fish }\end{array} & 42 & 16.46 & 2.7 \\ \text { TOTAL } & 111 & 101.3 & 16.6 \\ & 267 & 611.8 & 100.6\end{array}$

the ranking of the 10 major animal species at Taddlock is as follows: deer, $55.5 \%$; carp sucker, $7.1 \%$; catfish, $6.3 \%$; opossum, $5.1 \%$; turkey, 3.2\%; squirrel, 3.1\%; jackrabbit, $2.1 \%$; freshwater drum, $1.8 \%$; raccoon, $1.8 \%$; and beaver, $1.5 \%$.

Certain behavioral characteristics of the vertebrates present at the Taddlock site suggest it was utilized on a year-round basis. The gar and hibernation habits of the raccoon and some of the turtles indicates these animais were most likely procured during the late spring, summer, or early fall periods. A young fawn that died around June shows a summer occupation. Deer crania with shed antlers, plus the occurrence of migratory fowl like the grebe, teal, and flicker, point to a late fall, winter, and early spring occupation. In combination, this information is indicative of a yearround permanent settlement, probably over a relatively short span of time, perhaps two to three generations, by occupants of the Pecan Grove phase.

All floral remains recovered from the Spoonbill site were recovered through the flotation of $268,000 \mathrm{~cm}^{3}$ of soil from six features. Evaluation of the data must take into consideration the many different factors pertaining to plant carbonization (see Dennell 1976). The vast majority of carbonized plant remains belong to plant foods with dense, inedible parts such as large fruit pits, nut and acorn shells, and corncobs and/or cupules, rather than to nondense plant foods with a high water content or those plant foods normally ingested in entirety. Determinations of economic importance, as well as quantitative treatments, must therefore be assessed by as many means as possible, including the total range of the plant resources utilized, their context, and the type of inferred activities in- 
volved in collecting and processing specific resources.

The identified floral material from Spoonbill was carbonized through in situ burning and derives from 6 of the 11 cultural features recorded at the site; the flotation residue from the other five features has yet to be studied at this date. Two of the six features are claylined hearths which contained the majority of the nutshell and seeds; three are basinshaped pits between $15-25 \mathrm{~cm}$ in depth, and one resembles a smudge-pit (Binford 1972: 41; Guy 1981:105) and contained the majority of the corn cupules and at least six corncob sections and carbonized cornstalk (Bruseth and Perttula 1981:46).

Quantities of carbonized seeds were recovered from the Spoonbill site (Table 4). Identified forest fruits such as grape, berry, persimmon, and passionflower were probably gathered along streams and in open woods and thickets. The fruits are available in the late summer and fall, and were likely stored and dried for winter use. Persimmon fruits could have been made into beer, bread, or eaten raw. One grain, marsh millet, was recovered. Marsh millet was presumably available during the fall in specific aquatic locations such as sloughs and small remnant channel lakes in the alluvial bottomlands of Lake Fork Creek and the Sabine River.

Knotweed and chenopods are herbaceous annuals that produce an abundance of seeds in the middle to late summer. The small number recovered suggests they may be incidental anthropogenic plants rather than food products. Wild beans are annuals that also grow on disturbed ground and open areas. The seeds could be eaten raw or boiled when available in the summer; roasting and cooking the flour into gruel has also been suggested (Shea 1980). Since beans generally preserve poorly (Gasser and Adams 1981: 183-184), the significant numbers found at Spoonbill probably do represent food remains.

Sunflower and marshelder are present in small numbers. Marshelder is a weedy annual that grows in small, concentrated patches along streams, sloughs, and in disturbed and

Table 4. Identified Floral Material from the Spoonbill Site.

Common Name

Hickory nutshell/kernels

Acorn nutshell/kernels

Black walnut nutshell

Beeweed

Bullnettle seeds

Thistle seeds

Wild lettuce seeds

Persimmon seeds

Passionflower seeds

Plum/Cherry endocarps

Marshmillet grains

Wild bean cotyledons

Morning glory seeds

Sunflawer seeds

Knotweed seeds

Marshelder seeds

Goosefoot seeds

Grape seeds

Grape stems

Unidentified seeds

Corn cupules

Corn kernels
Scientific Name

Carya spp.

Quercus spp.

Juglans nigra

Cleome sp.

Cridoscolus sp.

Cirsium sp.

Lactuca sp.

Diospyros sp.

Passiffora sp.

Prunus sp.

Zizaniopsis miliacea

Strophostyles helvola

Ipomoea sp.

Heliantuhs sp.

Polygonum sp.

Ive sp.

Chenopodium sp.

Vitis sp.

Vitis $\mathbf{s p}$

Zea mays L.

Zes mays L.
N

$325,000^{*}$

$600^{*}$

18

$1 F^{* *}$

3F

$1 \mathrm{~F}$

IW

$1 F$

$1 \mathrm{~W} ; 2 \mathrm{~F}$

$1 F$

$72 W ; 10 F$

3W;22F

$57 W$

$3 W ; 1 F$

$41 W$

$185 W$

$51 W$

$60 \mathrm{~W} ; 13 \mathrm{~F}$

6
7

469

4
Wt (gms)

2145.9
3.9
1.9
$T$
0.1
$T$
$T$
$T$
$T$
$T$
$T$
$T$
$T$
$T$
$T$
$T$
$T$
$T$
$T$
$T$
4.3
$T$

"Estimate based on 150 nutshells per gram

" " $F=$ fragment; $W=$ Whole; $T=$ trace, lese than 0.1 gram 
open ground (Asch and Asch 1978:309). Boiling or roasting the seeds produces a valuable oil high in carbohydrates and fats. The Spoonbill achenes measured have a mean length of $2.9 \mathrm{~mm}$ (Crane 1982), approximately the size of modern sumpweed species rather than cultigens (Yarnell 1978:297, Table 2). Sunflowers have an extremely high calorie, protein, and fat composition, particularly when processed as a flour (Watt and Merrill 1963).

Carbonized nut remains are common at Spoonbill and Taddlock, and at a number of Early Caddoan sites in the Sabine River Basin (Bruseth and Perttula 1981:Table 7-7). Oak, hickory, pecan, and walnuts were utilized, with hickory accounting for over $99 \%$ of the Spoonbill sample by weight. Hickory is the most abundantly represented nut species at the George C. Davis site on the Neches River, occupied ca. A.D. 780-1260 (Jackson 1981).

Acorns are more common only at Taddlock and other Early Caddoan Pecan Grove phase sites dating prior to ca. A.D. 1100. Both black oak (i.e., willow oak and blackjack) and white oak (white oak and post oak) groups were utilized. Since acorn nutshells are less dense than hickory nutshells, their presence is probably well under-represented (cf. Chapman and Shea 1981).

Corn is the only tropical cultigen recovered from Early Caddoan flotation samples in the Sabine Basin; the common bean and squash are present in small quantities at the nearby Late Caddoan Steck site (Fig. 1). Maize is present in flotation samples from every Pecan Grove phase site excavated in the Sabine Basin (Bruseth and Carter 1980; Bruseth and Perttula 1981:Table 7-8), and in context at least, is comparable to the widespread utilization of nuts. Its frequency within sites and features is relatively low, however, suggesting other factors should be taken into consideration in evaluating its importance from the paleobotanical record. Corn may be overrepresented relative to other plant remains when the high correlation between smudge pits and carbonized corn cobs is noted. This points to a higher probability of preservation when the "food stuff" is also used as a fuel. In a preservation context similar to the nutshells, the kernels and cupules seem to represent traces of food preparation/consumption and incidental inclusions resulting from proc- essing activities such as corn parching. In these instances, the quantity and density of nutshells is considerably more than corn at Spoonbill and Taddlock. The fact that only one of the six features from Spoonbill had corn in quantity, while all the features had a considerable amount of nutshells, points to a lesser utilization of corn relative to wild plant foods such as nuts.

The common bean does not preserve very well, so its absence is not unexpected on this basis. The bean was certainly utilized in the region after A.D. 1350 . Since the common bean was apparently the last of the tropical cultigen triad of maize-beans-squash to be successfully introduced and adapted to the environment of the Eastern United States, temporal considerations may also account for its absence. Yarnell $(1976: 272)$ indicates that the earliest evidence for the common bean in the east is about A.D. 1050.

The triad of maize-beans-squash is nutritionally sound, with high protein quality, even though the individual constituents contain incomplete or low values in essential amino acids (Wing and Brown 1979). Corn is high in calories and carbohydrates, while beans are generally high in calcium and phosporus, critical nutrients during pregnancy and lactation.

The Caddo are reported to have cultivated two crops of corn each year. The "little corn" was planted in April and harvested in May, while the "flour corn" was planted in the late spring and harvested at the end of July (Swanton 1942:130). The "little corn" was similar to a popcorn, while the "flour corn" may have been a flint corn. It is unclear what type of corn was utilized during the Pecan Grove phase. No complete cobs were recovered, so patterns of row numbers or cob shapes could not be obtained. Information on kernel shape was prohibited by the fact that only four were recovered. Other than the George C. Davis (Jones 1949; Ford 1974) and Hanna sites (Shea 1980), there is a lack of regional data on Caddoan maize. Both Eastern Eight Row, Midwest 12 Row, and North American Pop have been identified, with 8 and 10-rowed corn most frequent. Until the types of corn present at a series of Caddoan sites can be positively identified, it will be impossible to evaluate subsistence models that rely on the Caddoan ethnographic record 
(Keller 1977).

\section{CONCLUSIONS}

The exploitation of animal food sources was primarily for protein. Animal prote in supplies all of the essential amino acids in about the same proportion as they are needed by the human body, thus promoting the effcient utilization of energy. The variety of protein sources utilized insured an adequate protein supply with little chance of deficiencies.

The acquisition of carbohydrates and fat energy sources comes primarily from the plant foods. Fats, the most concentrated dietary source of energy, come mainly from hickory, pecan, black walnut, and the oily seed plants such as marshelder and sunflower. Nuts and maize occurred in all contexts sampled, but it is probable that the degree of utilization is not comparable even if the amount cannot be quantified. The utilization of maize has been estimated at $30-40 \%$ of the diet of Caddoan groups (Story 1981:148), but it was not specified whether this applied to both the Early and Late Caddoan occupations in East Texas.

It is important to stress the complementary nature of corn and nut utilization (Keller 1977; Perttula 1981). Nuts contain large quantities of calories, protein, and fats, while corn is high in carbohydrates and calories. In addition, the vegetable oil produced by the boiling of hickory nuts is extremely high in calories (Watt and Merrill 1963). The nut resources, importantly, are relatively generalized in nutritive value. They contribute to all the energy classes being considered. Seeds are low-level energy producers, while maize is clearly selected for its abundance in carbohydrate production.

Combined with other plant and animal foods that contribute certain vitamins and other nutrients, the judicious combination of these food sources would result in an extremely well balanced diet. To summarize, the diet of the Early Caddoan inhabitants of the Sabine River Basin depended upon a wide variety of animal and plant foods. The procurement of animal foods was principally during the summer and fall, though some hunting activities were conducted year-round. The procurement of nuts was a fall activity, and a substantial contributor to the diet. Certain native plants like sumpweed and goosefoot were utilized as sources of oil and carbohydrates. Maize was present prior to the eighth century A.D. in the Sabine Basin, but was not the major contributor to the diet until some centuries later, and beans and squash were not apprently utilized at this time.

\section{REGIONAL AND TEMPORAL CONSIDERATIONS}

There is little systematically collected or published paleobotanical and faunal information in the Caddoan area that can contribute to understanding changes in subsistence strategies. Some regions have better faunal and floral records than others, particularly the dry Ozark bluffshelters utilized by the Arkansas and White River Valley Caddoan groups after ca. A.D. 900 (Sabo 1982; Wyckoff 1980), though the majority of this information has only recently been restudied from 1930 s museum-curated food remains (Cleland 1965; Ford 1981; Fritz 1981).

An examination of gram weight percentage compositions of plant foods from selected published Caddoan sites (Table 5) suggests that there is a decrease in the representation of wild plant resources such as nuts, and a corresponding increase in the frequency of cultigens, maize and beans, in the Late Caddoan period (see Chapman and Shea 1981: Table 3 for analogous temporal changes in the Little Tennessee River Valley). Early Caddoan subsistence data from the Hanna and Crenshaw sites (see Byrd 1980; Shea 1980; Perttula 1981) in the Middle Red River Valley are directly comparable to the data from the Sabine River Basin (i.e., a generalized strategy based on wild plants and a wide variety of animal resources, supplemented with cultigens such as maize and squash). In the early Caddoan sites examined, maize accounts for less than $10 \%$ by weight of the total floral samples.

From the Roden site, a fourteenth to seventeenth century settlement on Red River, the subsistence data are very different. The analysis of skeletal lesions, caries frequencies, and the wear patterns on teeth led Rose et al. (1981:125) to conclude that there was "a large carbohydrate component in the diet, while the scanning electron microscope does not indicate the use of nuts and a low 
Table 5. Gram Weight Percentage Compositions of Plant Foods from Caddoan Sites Published in the Literature.

Cultural Period

Early Caddoan Period

Alto Focus Hanna (16RR4)* *

Pecan Grove Spoonbill (41WD109)

Taddlock (X41WD39)

Late Caddoan Period

Titus Focus Steck (41WD125)

"TGW = total gram weight

* "From Shea 1980

consumption of unprocessed plant fiber. These data indicate that maize formed a significant part of the diet at the Roden site."

In the Arkansas Basin and Western Ozark Highlands of Oklahoma, Arkansas, and Southwest Missouri, tropical cultigens such as maize, squash, common bean, and bottle gourd occur more frequently and consistently than wild plant foods after ca. A.D. 900. On this basis, it has been argued that the subsistence strategy of the Caddoan inhabitants of this region was a fully developed agricultural economy supplemented with the exploitation of woodland animal species like deer and turkey (Sabo 1982; Wyckoff 1980). Native cultigens such as sumpweed and sunflower were also utilized, along with other possible native cultigens like goosefoot, amaranth, knotweed, giant ragweed, and maygrass. After ca. A.D. 1300, bison exploitation became more frequent while the evidence of sedentary settlements along the western flanks of the Ozarks became sparse, suggesting the adoption of seasonal bison procurement and semisedentary farming (Wyckoff 1981).

There is every reason to infer that substantial regional differences in the timing and development of horticultural and agricultural strategies exist within the Caddoan area. This is based solely on the considerable regionally specific ecological and environmental diversity within the Trans-Mississippi South. The adoption of an agricultural strategy will be variable in benefits across environmental zones and through time, such that the change to an agricultural economy was probably not synchronic within or between regions in the Caddoan area. Instead, this change occurred at different times in a time-transgressive process as secure yields of cultigens were reached that surpassed the potential of natural resources in the different regions. Therefore, it is entirely possible that agricultural economies may have existed among Caddoan populations in the Western Ozark Highlands at the same time a more generalized horticultural and wild resources strategy was in use in the Western Gulf Coastal Plain.

Returning to the Sabine River Basin, Late Caddoan and historic Caddoan sites like Steck and Gilbert have lower diversity indices, with deer and turkey present in high frequencies. Age culling seems to have been practiced in the exploitation of deer, with primarily the $1 \frac{1}{2}$ to 3 year-old classes being taken. This selection far exceeds the proportion in which this age group occurs in a natural population (Emerson 1980:126) and is more comparable to the pattern of faunal exploitation in the Central Mississippi Valley Mississippian period with the dominance of deer and turkey than to the Lower Valley with its emphasis on fish and a lesser dependence on deer and turkey (Springer 1980:201-202).

The eighteenth century Gilbert site (Fig. 1) further exemplifies the changing cultural strategy of faunal exploitation. The majority of the deer killed at Gilbert were between $11 / 2$ and 3 years of age (+100 MNI); deer, moreover, represented over $80 \%$ of the $\mathrm{MNI}$ and were the major source of food at the site (Lorrain 1967:225, 232).

Obviously, the regional data base is scanty 
and high priority should be placed not only on the excavation of sites with good ecofactual preservation, but also on the systematic analysis and publishing of Caddoan subsistence data. Whether the suggested subsistence strategy changes are accurate can hardly be evaluated at this point, though this should certainly be a priority. The relative utilization and contribution of maize, as well as models that account for the development of agricultural economics (e.g., Rindos 1980), remain to be assessed and tested within any one region of the Caddoan area.

\section{ACKNOWLEDGMENTS}

We would like to thank Dr. Barbara H. Butler for the faunal analysis of the Taddlock material and Ms. Cathy Crane for the floral analyses. Mr. Bob Skiles participated in the excavations at the two sites, and his good spirits and dedication to Wood County archaeology are appreciated. Appreciation also goes to Dr. Laverne Herrington of the Texas Antiquities Committee for her efforts to secure financial assistance for work at Spoonbill and also for her help in the field investigations. Lastly, the comments of the two anonymous reviewers were helpful, but we remain responsible for any errors of interpretation or omission.

\section{REFERENCES CITED}

Asch, Nancy B., and David L. Asch

1978 The Economic Potential of Iva annua and Its Prehistoric Importance in the Lower Illinois Valley. In The Nature and Status of Ethnobotany, edited by Richard I. Ford. Anthropologkal Papers 67. University of Michigan, Ann Arbor.

Bayham, Frank E

1979 Factors Influencing the Archaic Pattern of Animal Exploitation. The Kiva 44(2):219-235.

Binford, Lewis R.

1972 An Anchaoological Perspective. Academic Press, New York.

Bruseth, James E., Joe T. Bagot, Kimball M. Banks, and Mary A. McKinley

1977 Archaeological Research at Lake Fork Reservoir: Site Inventory and Assessment. Southern Methodist University, Archaeology Research Program, Research Report 87.

Bruseth, James E., and Carol Carter

1980 Paleobotanical Assessment. In Archaeological Reseerch at Lake Fork Reservoir: Excavations at the Howle Site and Site Testing, assembled by James E. Bruseth and Timothy K. Perttula. Southern Methodist University, Archeeology Research Program.
Bruseth, James E., and Timothy K. Perttula

1980 Archaeological Research at Lake Fork Reservoir: Excavations at the Howle Site and Site Testing. Southern Methodist University, Archaeology Research Program.

1981 Prehistoric Settlement Patterns at Lake Fork Reservoir. Texas Antiquities Permit Series, Report 2. Archaeology Research Program Press, Southern Methodist University

Butler, Barbara H., and Timothy K. Perttula

1981 Faunal Remains. In Prehistoric Settlement Pattems at Lake Fork Reservoir, by James E. Bruseth and Timothy K. Perttula, pp. 117-125. Texas Antiquities Permit Series, Report 2. Archaeology Research Program Press, Southern Methodist University.

Byrd, Kathleen $M$.

1980 Zooarchaeological Analysis of the Hanna Site: An Alto Focus Occupation in Louisiana. In The Hanna Site: An Alto Village in Red River Parish, edited by Prentice M. Thomas, L. Janice Campbell, and Steven R. Ahler. Louisiana Archaeology 5:235-265.

Chapman, Jefferson, and Andrea B. Shea

1981 The Archaeobotanical Record: Early Archaic Period to Contact in the Lower Little Tennessee River Valley. Tennessee Anthropologist 6(1):61-84

Cleland, Charles E.

1965 Faunal Remains from Blutt Shelters in Northwest Arkansas. The Arkansas Archaoologist 6:39-63.

Crane, Cathy J.

1982 Plant Utilization at Spoonbill, an Early Caddo Site in Northeast Texas. Midcontinental Journal of Archaeology 7:81-97.

Dennell, Robert W.

1976 The Economic Importance of Plant Resources Represented on Archaeological Sites. Journal of Archaeological Science 3(3):229-247.

Doehner, Karen, Duane Peter, and S. Alan Skinner

1978 Evaluation of the Archaeology at the Proposed Cooper Lake. Southern Methodist University, Archaeology Research Program, Ro search Report 114.

Emerson, Thomas E.

1980 A Stable White-Tailed Deer Population Model and Its Implications for Interpreting Prehis toric Hunting Patterns. Midcontinental Journal of Archaeology 5(1):117-132.

Ferring, C. Reid (editor)

1982 The Late Holocene Prehistory of Delaware Canyon, Oklahoma. Contributions in Anchao ology Number One. Institute of Applied Sciences, North Texas State University, Denton. 
Ford, Richard I.

1974 Preliminary Report on the Plant Remains from the Davis Site, Cherokee County, Texas. Ethnobotanical Laboratory Report 462. Museum of Anthropology. University of Michigan.

1981 New Ideas about the Origin of Agriculture Based on 50 Years of Museum-Curated Plant Remains. In The Research Potential of Anthropological Museum Collections, edited by Anne-Marie E. Cantwell, James B. Griffin, and Nan A. Rothschild. The New York Academy of Sciences Annals 376.

Fritz, Gayle J.

1981 Desiccated Botanical Remains from Three Bluff Shelter Sites in the Pine Mountain Project Area, Crawford County, Arkansas. Report submitted to the Arkansas Archeological Survey.

Gasser, Robert E., and E. Charles Adams

1981 Aspects of Deterioration of Plant Remains in Archaeological Sites: The Walpi Archaeological Project. Journal of Ethnobiology 1(1):182-192.

Gould, F. W.

1969 Texas Plants: A Checklist and Ecological Study. Texas A \& M University, Miscellaneous Papers.

Guy, Janice

1981 Cultural Features. In Archaeological Investigations at the George C. Davis Site, Cherokee County, Texas: Summers of 1979 and 1980 , edited by Dee Ann Story, pp. 37-123. Texes Archeological Research Laboratory Occasional Papers 1.

Henderson, Jerry

1978 The Vertebrate Fauna. In Archaeological Re search at Proposed Cooper Lake, Northeast Texas, 1974-1975, edited by Karen Doehner and Richard E. Larson, pp. 99-144. Southem Methodist University, Archaeology Research Program, Research Report 108.

Jackson, Jack $M$.

1981 Floral and Faunal Remains. In Archaeological Investigations at the George C. Davis Site, Cherokee County, Texas: Summers of 1979 and 1980 , edited by Dee Ann Story, pp. 347-360. Texes Archeological Research Laboratory, Occasional Papers 1.

Jones, Volney $H$.

1949 Maize from the Davis Site: Its Nature and Interprelaiion. In The George C. Davis Site, Cherokee County, Texas, edited by H. Perry Newell and Alex D. Krieger, pp. 241-249. Memoirs of the Society for American Archaeology 5.

Keller, John E.

1977 Subsistence Paleoecology at the George C. Davis Site: Strategies and Consequences. The Western Canadian Journal of Anthropology 7(1):100-128.
Krieger, Alex D.

1946 Culture Complexes and Chronology in Northern Texas. University of Texes Publication 4640. Austin.

Küchler, A, W.

1964 Potential Natural Vegetation of the Conterminous United States. American Geographical Society, Spocial Publication 36.

Lorrain, Dessamae

1967 Animal Remains. In The Gilbert Site: A Norteno Focus Site in Northeastern Texas, edited by Edward B. Jelks. Bulletin of the Texas Archeological Society 37:225-243.

Lynott, Mark J.

1980 Prehistoric Bison Populations of Northcentral Texas. Bulletin of the Texas Archeological Society 50:89-101.

Mahler, William F.

1973 Botanical Survey of the Lake Monticello Area. Southern Methodist University, Contributions in Anthropology 9.

Perttula, Timothy $\mathrm{K}$

1981 Caddoan Prehistory: The Evolution ol Agricultural Societies in the Trans-Mississippi South. Paper presented at the 46th Annual Meeting of the Society for American Archaeology, San Diego, California.

Rindos, David

1980 Symbiosis, Instability, and the Origins and Spread of Agriculture: A New Model. Current Anthropology 21(6): 751-772.

Robison, Neil D.

1982 A Critical Review of Mississippian Hunting Patterns and Their Antiquity. Tennessee Anthropologist 7(1):62-74.

Rose, Jerome C., Phyllis M. Clancy, and Peer H. MooreJansen

1981 Bioarchaeology of the Roden Site. In Archaeological Investigations at the Roden Site, McCurtain County, Oklahoma, edited by Gregory Perino, pp. 99-129. Museum of the Red River, Idabel, Oklahoma.

Sabo, George II

1982 The Huntsville Site (3MA22): A Caddoan CivicCeremonial Center in the Arkansas Ozarks. Paper presented at the 47th Annual Meeting of the Society for American Archaeology, Minneapolis.

Shea, Andrea B.

1980 Analysis of Plant Remains from the Hanna Site. In The Hanna Site: An Alto Village in Red River Parish, edited by Prentice M. Thomas, L. Janice Campbell, and Steven R. Ahler. Louisiana Archaeology 5:273-285

Skiles, Bob D., James E. Bruseth, and Timothy K. Perttula

1980 A Synthesis of the Upper Sabine River Basin Culture History. The Record, Newsletter of the Dallas Archeological Society 36(1):1-12. 
Smith, Bruce D.

1975 Middle Mississippi Exploitation of Animal Populations. Anthropological Papers 57. Museum of Anthropology, University of Michigan.

1978 Prehistoric Patterns of Human Behavior: A Case Study in the Mississippi Valley. Academic Press, New York.

Springer, James $W$.

1980 An Analysis of Prehistoric Food Remains from the Bruly St. Martin Site, Louisiana, with a Comparative Discussion of Mississippi Valley Faunal Studies. Midcontinental Journal of Archaeology 5(2):193-223.

Story, Dee Ann

1981 An Overview of the Archaeology of East Texas. Plains Anthropologist 26:139-156.

Story, Dee Ann, and Sam Valastro Jr.

1977 Radiocarbon Dating and the George C. Davis Site, Texas. Journal of Field Archaeology 4(1):63-89.

Swanton, John R.

1942 Source Material on the History and Ethnology of the Caddo Indians. Smithsonian Institution, Bureau of American Ethnology, Bulletin 132.

Watt, B. K. and A. L. Merrill

1963 Composition of Foods. Handbook No. 8. United States Department of Agriculture, Washington, D.C.

Wing, Elizabeth S., and Antoinette B. Brown

1979 Paleonutrition: Method and Theory in Prehistoric Foodways. Academic Press, New York.

Wyckoft, Dan G.

1980 Caddoan Adaptive Strategies in the Arkansas Basin, Eastern Oklahoma. Unpublished Ph.D. dissertation, Washington State University.

1981 Pollen, Plants and People: Some Archaeological Perspectives on Eastern Oklahoma Prehistory. In Ferndale Bog and Natural Lake: Five Thousand Years of Environmental Change in Southeastern Oklahoma, by Lois E. Albert, pp. 101-107. Oklahoma Archeological Survey, Studies in OKlahoma's Past 7.

Yarnell, Richard A.

1976 Early Plant Husbandry in Eastern North America. In Cultural Change and Continuity, edited by Charles E. Cleland, pp. 265-272. Academic Press, New York.

1978 Domestication of Sunflower and Sumpweed in Eastern North America. In The Nature and Status of Ethnobotany, edited by Richard I. Ford. Anthropological Papers 67:289-299. Museum of Anthropology, University of Michigan.
Timothy K. Perttula Institute of Applied Sciences North Texas State University Denton, Texas 76201

James C. Bruseth Archaeology Research Program Southern Methodist University Dallas, Texas 75275

July 1982 


\title{
THE TADDLOCK SITE
}

\author{
Timothy K. Perttula
}

The Taddlock site (41WD482 or $\mathrm{X} 41 \mathrm{WD} 39)^{1}$ is a prehistoric Caddoan ${ }^{2}$ settlement located in the Upper Sabine River Basin, Wood County, Texas. Taddlock lies on a combined upland remnant and alluvial terrace in the Lake Fork Creek valley, a major tributary to the Sabine River.

The site was recorded in 1975 during the survey of Lake Fork Reservoir by Southern Methodist University. ${ }^{3}$ It was then excavated in 1978 as part of the SMU archaeological program to mitigate the effects of reservoir construction on the cultural resources found there. ${ }^{4}$ Controlled surface collections of cultural materials, hand excavated units, and backhoe-aided excavations were employed to investigate the site's archaeological deposits.5 The prehistoric Caddoan occupation was concentrated in a 1,200 square meter area on the highest elevations of the upland remnant. 6

The occupation at Taddlock dates to the Early Caddoan period, and is associated with the Sanders focus or phase 7 , a cultural entity found in Northeast Texas and Southeast Oklahoma between the Sabine and Red River valleys. ${ }^{8}$ The Sanders focus or phase dates from ca. A.D. 900 to A.D. 1350; calibrated radiocarbon dates ${ }^{9}$ for the Sanders focus or phase range from ca. A.D. 900 to A.D. 1320.10 In the Upper Sabine River Basin, sites of the Early Caddoan period are included in the Pecan Grove phase, a local manifestation of the Sanders focus or phase.11 The Taddlock radiocarbon dates suggest

Friends of Northeast Texas Archaeology, Special Publication No. 1 (1995) 
that the occupation dates between A.D. $1037 \pm 74$ and A.D. $1070 \pm$ 77.12

Cartographic representations of artifact densities generated from controlled surface collections 13 indicated that the Caddoan occupational debris was concentrated in a crescent-shape around an area where cultural features and activity areas were not found.14 A storage pit and evidence for a single burial were recorded adjacent to one of two probable house locations. The two house locations were marked by shallow circular middens 9 meters in diameter containing internal features such as postholes and circular burned areas of charcoal and ash interpreted as remains of hearths.

A third midden deposit was in a gully about 10-20 meters downslope from the house locations. This midden was a $50 \mathrm{~cm}$ thick trash deposit where bone, plant remains, broken lithic tools, and ceramic vessels were discarded by the site occupants. ${ }^{15}$ The two house locations and trash midden were occupied contemporaneously. as sherds found in situ in the trash midden were refitted to other sherds from the same broken vessels found in the house deposits. The rapid deposition of trash in the gully created a microaggradational environment conducive to the preservation of faunal and floral remains.

Over 18,000 ceramic sherds were recovered from the Taddlock site. They represent several hundred different vessels, including carinated bowls, simple bowls, large cylindrical jars, and bottles 16 that were used for food storage, preparation, and consumption tasks. Decorated ceramic types include Canton lncised, Sanders Engraved, Davis Incised, East Incised, and Maxey Noded Redware.17 The 
engraved and noded ceramics were frequently covered with a slip of hematite-derived paint as another means of decoration. Additional ceramic artifacts found include pipes ${ }^{18}$, particularly the elbow pipe form and the long-stemmed or Red River pipe style. 19 Native tobacco, or mixtures of tobacco and other plants, may have been used for smoking. 20

The lithic assemblage is dominated by small arrowpoints (used on the bow and arrow), flake tools, and celts, used for hunting, butchering, scraping, and woodworking activities. Most of these tool types were manufactured on cherts available only in Central Texas or in Red River gravels, rather than from the poorer quality local materials. 21

A faunal sample of more than 13,000 identifiable elements was recovered in the trash midden. ${ }^{22}$ Animals from all vertebrate classes are present; a minimum of 267 individuals are represented. Deer contributed the greatest percentage of total meat to the Early Caddoan diet at Taddlock.23 Other important utilized species included the carp sucker, catfish, opossum, turkey, squirrel, jackrabbit, freshwater drum, raccoon, and beaver. Certain behavioral characteristics of the vertebrates present suggest the Taddlock site was used as a year-round permanent settlement. 24

Plant foods found at Taddlock include wild plant seeds, nuts (from black walnut, oak, hickory, and pecan), and the tropical cultigen corn.25 Better preserved floral remains from the nearby Spoonbill site 26 provide additional information about the use of plant species by Early Caddoan populations in the Upper Sabine River Basin. The collection of wild plant foods was important in the 
economy, but was apparently supplemented by the use of seeds of pioneer annuals, and corn. 27

The cultural material, provenience information, and all field notes from Taddlock are curated at Southern Methodist University, Dallas. 28

\section{Bibliography}

Primary Sources

Bruseth, J.E. and T.K. Perttula

1981 Prehistoric Settlement Patterns at Lake Fork Reservoir. Texas Antiquities Permit Series, Report No. 2. Texas Antiquities Committee, Austin, and Southern Methodist University, Dallas.

Krieger, A.D.

1946 Culture Complexes and Chronology in Northern Texas. Publication No. 4640. University of Texas, Austin.

Perttula, T.K., C.J. Crane, and J.E. Bruseth

1983 A Consideration of Caddoan Subsistence. Southeastern Archaeology 1:89-102.

Story, D.A.

1981 An Overview of the Archaeology of East Texas. Plains Anthropologist 26:139-156.

Secondary Sources

Newcomb, W.W., Jr.

1961 The Indians of Texas. University of Texas Press, Austin.

Suhm, D.A., A.D. Krieger, and E.B. Jelks

1954 An Introductory Handbook of Texas Archeology. Bulletin of the Texas Archeological Society 25. 
Swanton, J.R.

1942 Source Material on the History and Ethnology of the Caddo Indians. Bulletin 132. Smithsonian Institution, Bureau of American Ethnology, Washington, D.C.

Wyckoff, D.G.

1974 The Caddoan Culture Area: An Archaeological Perspective. Caddoan Indians, Volume 1:25-279. Garland Publishing, Inc., New York.

\section{FOOTNOTES}

1. The $\mathrm{X}$ prefix with the Smithsonian trinomial system indicates that the site was recorded by Southern Methodist University (SMU). It is the 39th site reported by SMU in Wood County, Texas.

2. For archaeological definitions of Caddo, see Story, D.A., 1978. Some Comments on Anthropological Studies Concerning the Caddo. In Texas Archeology, edited by K.D. House, pp. 46-68. Southern Methodist University Press, Dallas.

3. Bruseth, J.E., J.T. Bagot, K.M. Banks, and M.A. McKinley, 1977. Archaeological Research at Lake Fork Reservoir: Site Inventory and Assessment. Research Report 87, Archaeology Research Program, Southern Methodist University.

4. Bruseth, J.E. and T.K. Perttula, 1981. Prehistoric Settlement Patterns at Lake Fork Reservoir. Texas Antiquities Permit Series, Report No. 2. Texas Antiquities Committee, Austin, and Southern Methodist University, Dallas.

5. ibid., pp. 48-51.

6. op. cit., Figure 3-48.

7. Krieger, A.D., 1946. Culture Complexes and Chronology in Northern Texas. Publication No. 4640. The University of Texas at Austin. Story, D.A., 1981. An Overview of the Archaeology of East Texas. Plains Conference 26:139-156.

8. ibid.

9. Klein, J., J.C. Lerman, P.E. Damon, and E.K. Ralph, 1982. Calibration of Radiocarbon Dates: Tables Based on the Consensus Data of the Workshop on Calibrating the Radiocarbon Time Scale. Radiocarbon 24:103-150.

10. Mallouf, R.J., 1976. Archeological Investigations at Proposed Big Pine Lake, 1974-1975, Lamar and Red River Counties, Texas. Archeological Survey Report 18. Texas Historical Commission, Office of the State Archeologist, Austin. Skinner, S.A., R.K. Harris, and K.M. Anderson (editors), 1969. Archaeological Investigations at the Sam Kaufman Site, Red River County, Texas. Contributions in Anthropology 5. Southern Methodist University, Dallas. 
11. Bruseth and Perttula 1981, pp. 141-142.

12. University of Texas Radiocarbon Laboratory dates Tx-3048 (A.D. $1037 \pm 74$, corrected) and Tx-3046 (A.D. $1070 \pm 77$, corrected).

13. Three-dimensional contour maps depicting relative artifact densities were obtained with the aid of a synagraphic computer mapping program (SYMAP) developed by the Laboratory for Computer Graphics and Spatial Analysis, Harvard University.

14. Bruseth and Perttula 1981, Figure 4-11.

15. ibid., pp. 51.

16. See Suhm, D.A. and E.B. Jelks, 1962. Handbook of Texas Archeology: Type Descriptions. Texas Archeological Society, Special Publication 1, and Texas Memorial Museum, Bulletin 4, Austin.

17. ibid.

18. Bruseth and Perttula 1981, Figure 5-11.

19. Hoffman, M.P., 1967. Ceramic Pipe Style Chronology along the Red River Drainage in Southwestern Arkansas. The Arkansas Archeologist 8(1):4-14.

20. Haberman, T.W, 1984. Evidence for Aboriginal Tobaccos in Eastern North America. American Antiquity 49:269-287.

21. Perttula, T.K., 1984. Patterns of Prehistoric Lithic Raw Material Utilization in the Caddoan Area: The Western Gulf Coastal Plain. In Prehistoric Chert Exploitation: Studies from the Midcontinent, edited by B.M. Butler and E.E. May, pp. 129-148. Occasional Paper 2. Southern Illinois University, Center for Archaeological Investigations, Carbondale.

22. Perttula, T.K. and J.E. Bruseth, 1983. Early Caddoan Subsistence Strategies, Sabine River Basin, East Texas. Plains Anthropologist 28:9-21.

23. ibid: Table 3.

24. Bruseth and Perttula 1981, pp. 124-125.

25. ibid.: Tables 7-6 to 7-8.

26. Crane, C.J., 1982. Plant Utilization at Spoonbill, an Early Caddo Site in Northeast Texas. Midcontinental Journal of Archaeology 7:81-97.

27. Perttula, T.K., C.J. Crane, and J.E. Bruseth, 1983. A Consideration of Caddoan Subsistence. Southeastern Archaeology 1:89-102.

28. This paper was submitted to the managing editor of the Handbook of Texas in 1985. 


\title{
The Carlisle Site (41WD46), a Middle Caddoan Occupation on the Sabine River, Wood County, Texas
}

\author{
Timothy K. Perttula \\ Bob D. Skiles \\ and \\ Bonnie C. Yates \\ INTRODUCTION AND SETTING
}

The Carlisle site (41WD46) is located on the Sabine River near its confluence with Lake Fork Creek in the Upper Sabine River Basin. As defined by Perttula et al. (1986), the Upper Sabine River Basin includes the area from the headwaters of the Sabine River to the mouths of Cherokee Bayou and Hatley Creek at the western edge of the Sabine Uplift (Bureau of Economic Geology 1965). Lake Fork Creek is one of several large southsoutheastward flowing streams within the Upper Sabine River Basin. The town of Mineola is approximately 13 kilometers $(\mathrm{km})$ west of the Carlisle site.

The site is situated at the tip of an upland projection overlooking the Sabine River floodplain, but extends into the floodplain to within ca. 30 meters of the river bank (Figure 1). The Lake Fork Creek channel is approximately one $\mathrm{km}$ east of the site.

While the site was an improved pasture for many years prior to 1975 and to the present, it had been previously cultivated. In fact, this cultivation may have contributed to its initial identification in the early 1930s (see below), as well as its subsequent partial burial. The upland sandy soils derive from the Queen City Formation, and these are highly susceptible to erosion and colluvial downwasting. Colluvial deposition seems to have been a prominent factor in the burial of cultural materials along valley margins and lower footslopes elsewhere in the Upper Sabine Basin (Perttula et al. 1986), and the site's topographic position suggests that both alluvial and colluvial deposition is responsible for the burial of the floodplain cultural deposits at the Carlisle site.

\section{HISTORY OF INVESTIGATIONS}

The Carlisle site was initially recorded in 1930 by A.T. Jackson as a "dense midden deposit; many mussel shells" on the Harry Meredith farm (Wilson and Jackson 1930). When the site was re-recorded in 1975, the midden deposits were not visible on the surface and were exposed only in coring activities near the bank of the Sabine River. The midden deposits (here labelled Area B) were covered with ca. $20 \mathrm{~cm}$ of sterile overburden (Skiles et al. 1980). A second area of concentrated cultural deposits was identified on the adjacent upland projection elevated about five $m$ above the Sabine River floodplain (Area A). 


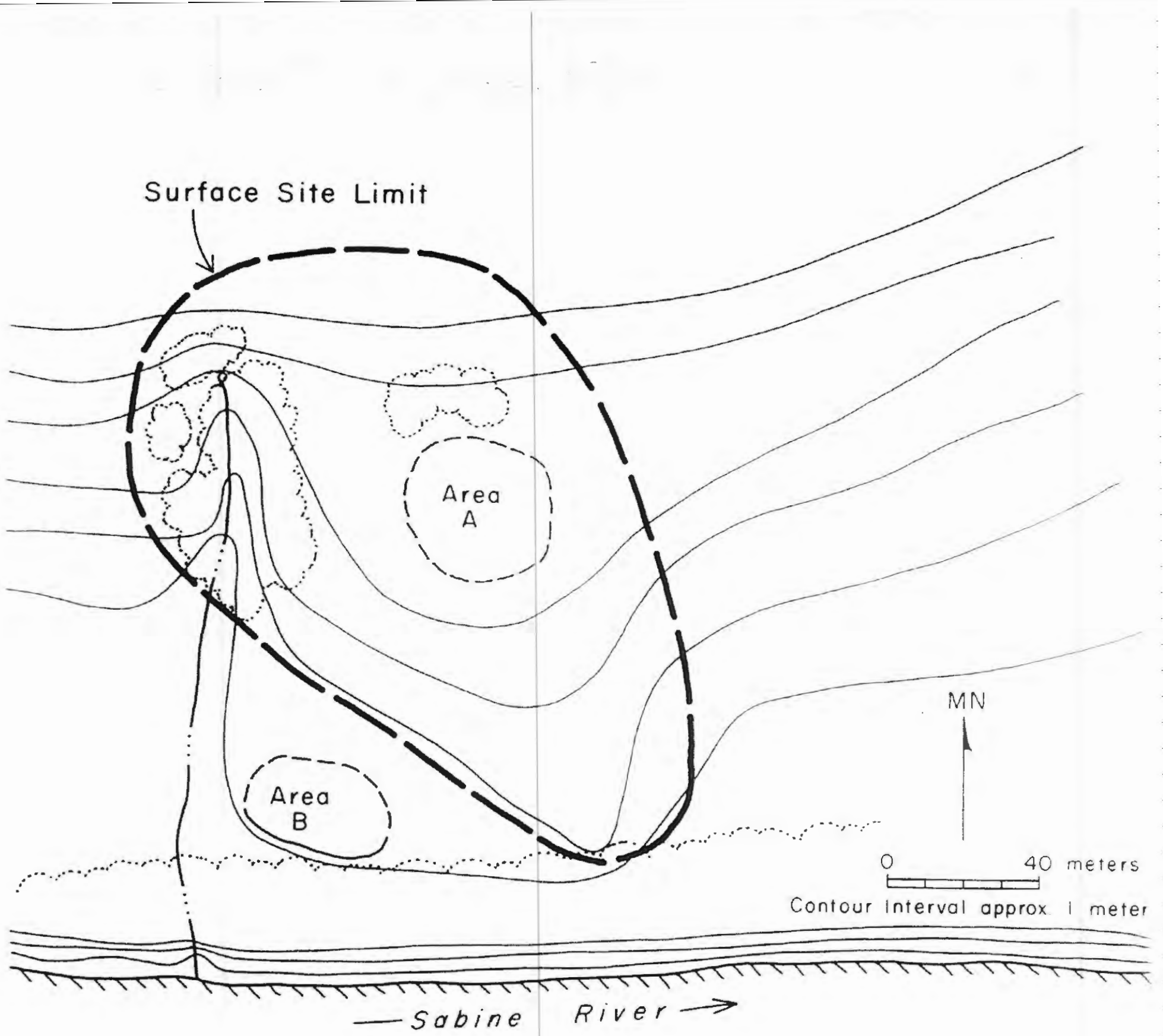

Figure 1. General Map of the Carlisle Site.

Test excavations were carried out in both areas of the site in 1975 by Skiles. In Area A Skiles excavated six $1 \times 1 \mathrm{~m}$ test units to sample the deposits on the upland landform, and two $50 \times 50 \mathrm{~cm}$ shovel tests were also excavated there in 1975 and 1986 (Figure 2). Although no obvious features or concentrations of cultural materials were encountered in the Area A excavations, most of the materials recovered (such as pieces of daub, a mud-dauber nest, and several large sherds from refired brushed and incised vessels) suggest that a Caddoan structure stood upon the crest of the upland projection. 


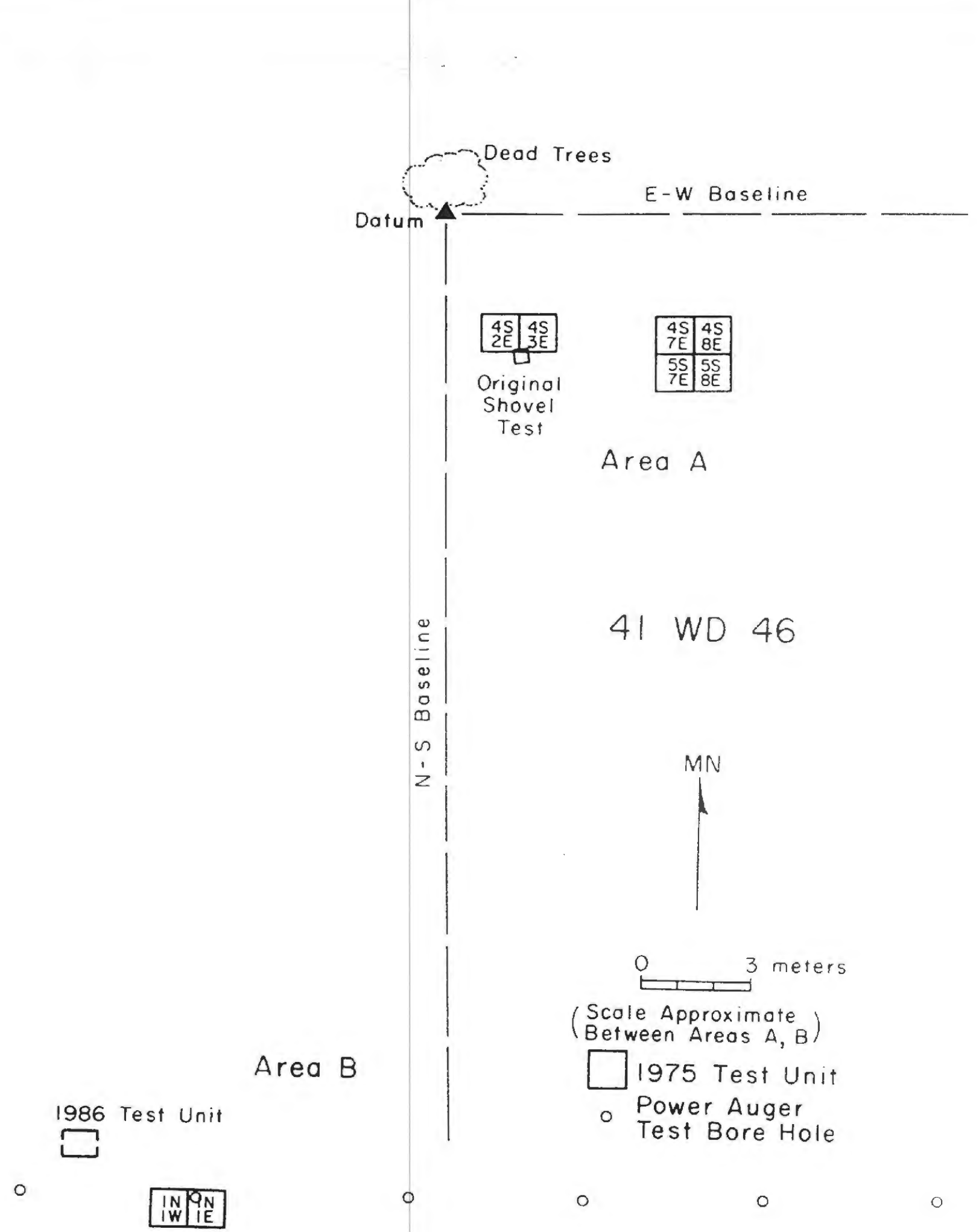

Figure 2. Plan of Site Excavations.

In 1975 a series of power augur holes excavated in Area B located a buried midden deposit at the site. Skiles excavated a 1 2 m unit in the midden in 1975 (see Figure 2), but because of the density of burned and unburned shell, the units were terminated prior to reaching sterile subsoil. Several thousand mussel shells were recovered in the midden, but 
were never properly studied as they were lost after being sent to Southern Methodist University for study.

More recently, the Carlisle site was revisited in January and March of 1986 as part of the archaeological reconnaissance of the proposed Waters Bluff Reservoir (Perttula 1986). As planned, this reservoir would cover a large area of the Sabine River floodplain in Wood and Smith counties, Texas, and at maximum floodpool levels (303 feet msl) would inundate the Carlisle site floodplain midden deposits.

Shovel testing in 1986 suggested that the midden may have been buried by as much as $50 \mathrm{~cm}$ of sand. The completion of an additional 1x1 m unit in March 1986 uncovered midden debris between ca. 20-25 to $55 \mathrm{~cm}$ below surface (Figure 3). Striae of pale brown sand within the midden indicates that alluvial and/or colluvial deposition occurred during the formation of the Caddoan floodplain midden deposits. The vast majority of the Area $B$ cultural materials were recovered in the plow zone and the buried midden. An occupational surface was recognized between ca. $25-35 \mathrm{~cm}$ (labelled Feature 1) in the midden. It was defined by a concentration of large ceramic sherds, many complete mussel shell valves, and turtle shell fragments all lying on a common horizontal plane. Charcoal from Feature 1 was dated to $540+/-60$ years B.P. (Beta-17494). Feature 1 in the 1986 investigations may be part of the larger shell concentration encountered in the 1975 work by Skiles, which is suspected to have been deposited in a large pit.

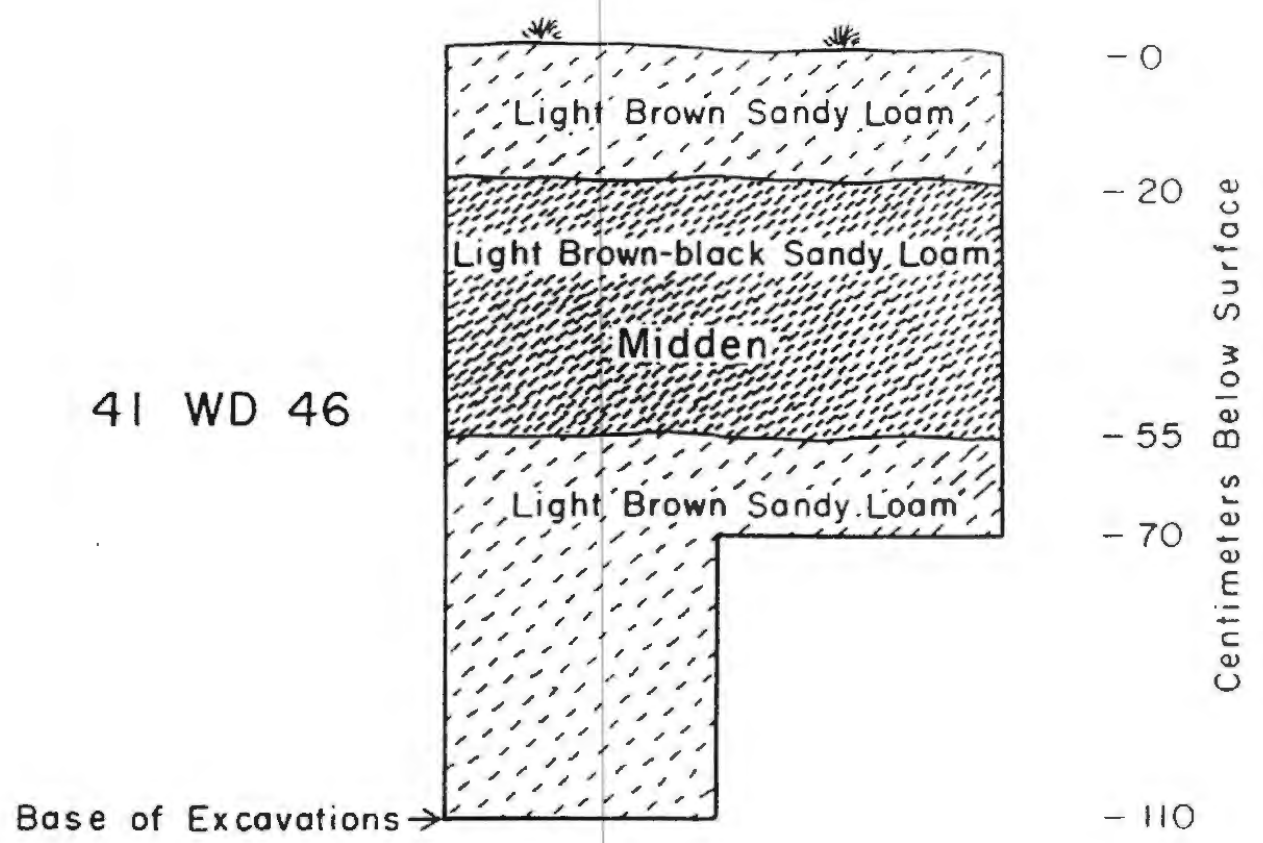

Figure 3. Area B Midden Profile. 
Mussel shells are a consistent component in Caddoan middens in the Upper Sabine River Basin that predate ca. A.D. 1400, with substantial quantities being recovered from excavations at sites such as Taddlock (41WD482), Son Gibson (41WD1), and 41WD36, all dating to the Early Caddoan period. Nevertheless, the absolute quantity and context of the mussel shell at Carlisle (i.e., a $30 \mathrm{~cm}$ thick, homogeneous lens) is very different from other Upper Sabine River basin middens.

\section{ARTIFACT ASSEMBLAGES}

A wide variety of artifacts was found at the Carlisle site in the 1975 and 1986 investigations (Table 1). Plain and decorated ceramic sherds and lithic debitage were the most common types of artifacts present at the site, followed by unifacial lithic tools, bifaces and biface fragments, and dart projectile points. Most of the materials were collected from the Area A knoll and the general surface, particularly the lithic tools and debris, while ceramic sherds and daub comprised 85 percent of the artifacts from the Area B midden (see Table 1).

Table 1. Artifact Assemblages

\begin{tabular}{lc|ccc}
\hline Artifact Classes & Area A & General Surface & Area B & Total \\
\hline Ceramics & 119 & 168 & 329 & 616 \\
Daub & & 3 & 7 & 10 \\
Burned Clay & 1 & & & 1 \\
Cores & 8 & 11 & 3 & 22 \\
Thin Bifaces & 1 & 16 & & 17 \\
Thick Bifaces & 5 & 17 & 1 & 22 \\
Biface Fragments & 7 & 25 & & 35 \\
Dart Points & 10 & 10 & 1 & 15 \\
Arrow Points & 4 & 1 & & 1 \\
Perforator & & 37 & & 65 \\
Piece esquille & & & & 1 \\
Unifacial Tools & 28 & 319 & 38 & 681 \\
Debitage & 324 & & 16 & 18 \\
Fire-cracked rock & 2 & 620 & 395 & 1524 \\
\hline \multicolumn{1}{c|}{ SUMMARY } & 509 & & & \\
\hline
\end{tabular}




\section{Lithics}

Including fire-cracked rock, 838 lithic artifacts were recovered from surface collections and limited excavations in Area A of the Carlisle site. While most of the lithic artifacts are from the surface collections (see Table 1), lithic densities from subsurface contexts are about 70 artifacts per cubic meter.

Dart points, bifaces and biface fragments, and a variety of unifacial tools (three scrapers, two alternately retouched pieces, and 65 unifacially worn flakes) are well represented in the Area A artifact assemblage. In general, the high frequency of bifaces and biface fragments, as well as cores, and the common discarding of broken dart projectile points, indicates that the manufacture and refurbishing of bifacial tools was a common activity at the site.

The types of dart projectile points found at Carlisle (Table 2) suggest considerable use of the site during Archaic and Early Ceramic periods (Figure 4 and 5). Corner-notched, parallel-stemmed, and contracting-stem arrowpoints represent the use of the bow and arrow by the Caddoan occupants of the Carlisle site.

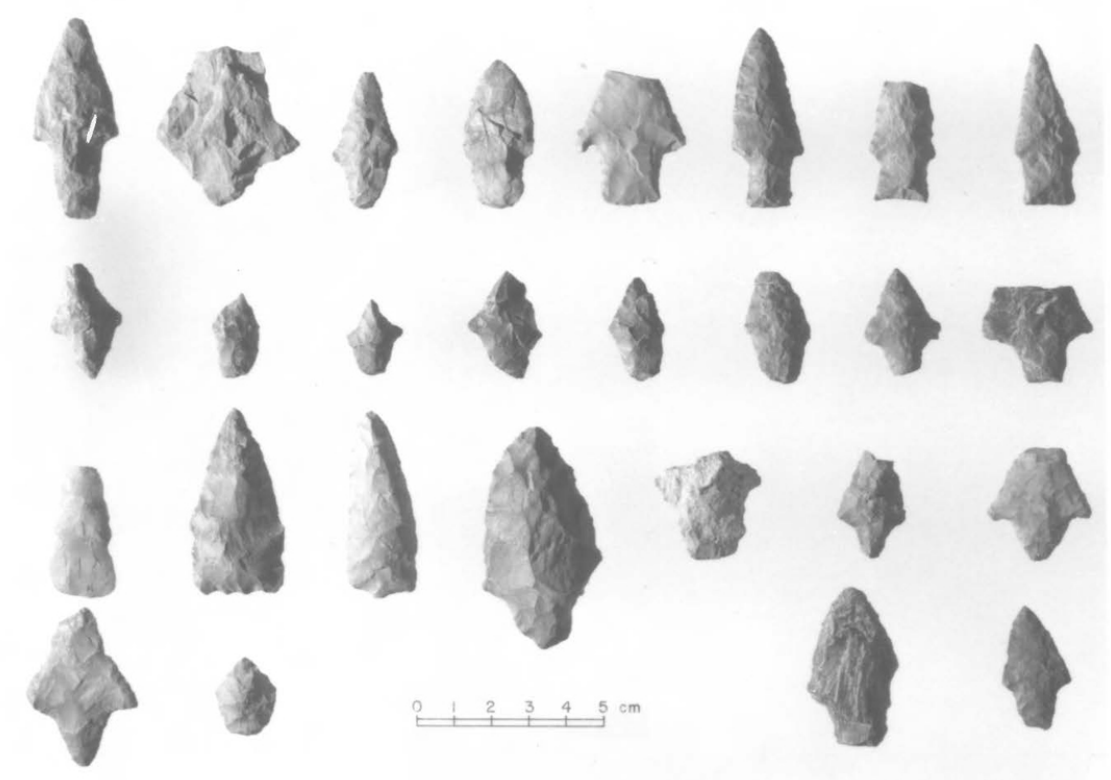

Figure 4. Dart Points from the General Surface: (top row, 1-r) Gary, Bulverde, and Yarbrough types, (second row, l-r) Gary types, (third row, l-r) Unidentified and Gary types, (bottom row, l-r) Gary and Kent types. 


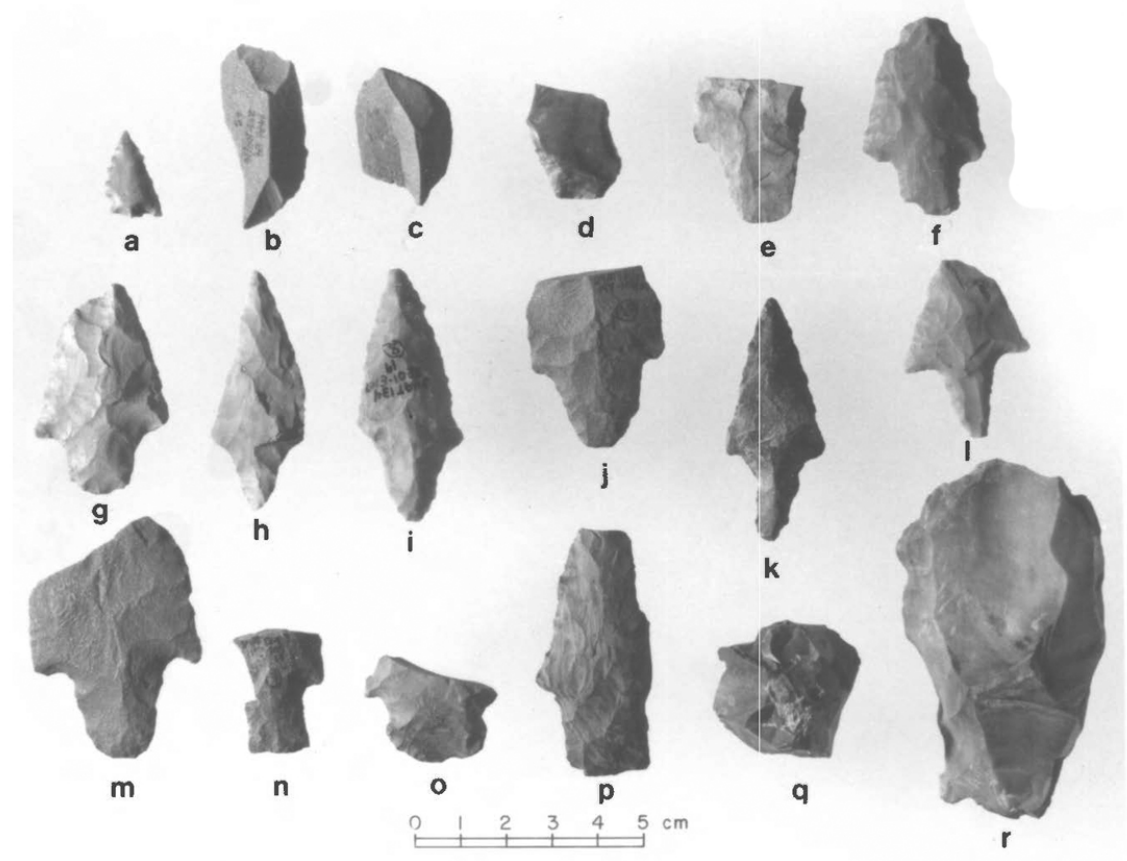

Figure 5. Lithic Tools, Area A.

Table 2. Dart Points.

\begin{tabular}{lcl}
\hline Types/varieties & General Surface & Area A \\
\hline Bulverde & 1 & \\
Wells & 2 & 1 \\
Kent & 3 & 1 \\
Yarbrough & 12 & 2 \\
Gary, var. Camden & 4 & \\
var. LeFlore & 8 & 1 \\
\hline
\end{tabular}

Cutting, scraping, woodworking, and other such activities on bone and wood were also important tasks conducted at the site as based on the flake tools (see Figure 5b-d, q). A single lithic tool used for perforating leather, wood, or bone was found on the site's 
surface (see Table 1); these types of perforators are common on Caddoan sites in the Upper Sabine River basin (Bruseth and Pertula 1981).

Most of the flake tools (about 65 percent) were on pieces of chert collected from local Sabine River gravels. Another 27 percent of these tools were on quartzite, and the remainder were on petrified or fossil wood; both these materials were also available in local gravels (Perttula 1984). The analysis of the types of flakes selected for tool use indicates that flakes with a point of applied force (i.e., complete or broken flakes) were preferred, along with flake fragments (flakes with a discernable ventral surface but lacking the point of applied force [Sullivan and Rozen 1985:759]). The debris flake type--that is, flakes lacking a striking platform, a bulb of percussion, and with margins that are not intact-comprises less than 10 percent of the unifacial/utilized pieces.

Broken flakes and flake fragments dominate the unused flakes in the Area $A$ assemblage (Table 3). Debris is also common from this part of the site, and complete flakes account for only 15.7 percent of the Area A flakes. The high proportions of broken flakes, flake fragments, and debris, along with the low number of cores, suggest that tool manufacturing activities were important compared to core reduction. The frequency of broken bifaces also hints at the frequency of manufacturing failures.

Unlike the flake tools, where chert was the preferred material, the unused flakes are primarily of coarse and fine-grained quartzites. These quartzites comprise between 63-73 percent of each of the four flake types in the debitage sample from Area A, which indicates their reduction during all phases of tool manufacture (Table 4).

Table 3. Percentages of Flake Types.

\begin{tabular}{lcc}
\hline Flake Types & Area A/General Surface & Area B \\
\hline Complete & 15.7 & 21.1 \\
Broken & 30.1 & 7.9 \\
Fragment & 31.3 & 36.8 \\
Debris & 22.8 & 34.2 \\
\hline TOTALS & 643 & 38 \\
\hline
\end{tabular}


There was a clear selectivity by the Carlisle site inhabitants for chert in tool use. Chert raw materials were about three times as likely to be selected for tools than the other raw materials in the lithic assemblage.

Table 4. Percentage of Flake Raw Materials.

\begin{tabular}{lcc}
\hline Raw Materials & Area A/General Surface & Area B \\
\hline Chert & 23.1 & 21.1 \\
Coarse-grained & 37.8 & 44.7 \\
Quartzite & & \\
Fine-grained & 26.6 & 21.1 \\
Quartzite & 8.4 & 2.6 \\
Petrified of Fossil Wood & 4.2 & 10.5 \\
Ferruginous Sandstone & & 38 \\
\hline TOTALS & 643 & \\
\hline
\end{tabular}

Two small unprovenienced pieces of fire-cracked ferruginous sandstone were found in one of the 1975 test pits at Carlisle. Ferruginous sandstone is available locally in bedrock outcrops of the Queen City Formation.

Few lithics were recovered from the buried Caddoan midden in Area B except for fire-cracked rock, a small assortment of cores, a biface fragement, and 38 pieces of lithic debitage. One fine-grained quartzite Scallorn arrowpoint was found at $80-90 \mathrm{~cm}$ below: surface, about $30 \mathrm{~cm}$ below the buried midden (see Table 1).

The Area B cores include core fragments of chalcedony, petrified wood, and a finegrained quartzite. The debitage was dispersed through a meter of alluvial sediments, with about 65 percent of it deriving from the buried midden deposits. The types of flakes present are again suggestive of tool manufacturing byproducts in that fragments and debris account for 71 percent of the Area B flakes (see Table 3). The use of raw materials for tool manufacture is similar between Areas A and B at Carlisle, with quartzites comprising 65.8 percent of the debitage in Area B (see Table 4). The petrified wood biface fragment was found between $40-50 \mathrm{~cm}$.

Sixteen pieces of ferruginous sandstone fire-cracked rock were found in Area B. The small pieces were all recovered in association with the buried midden, being most common $20-40 \mathrm{~cm}$ below surface. 


\section{Ceramics}

A total of 119 sherds were recovered from the test excavations at Area $\mathrm{A}$, along with another 168 sherds from the surface of the upland knoll. About five percent of these ceramics were tempered with bone, with the remainder being grog-tempered. Of the 83 decorated sherds, 51 percent have brushed bodies, 19 percent are incised, 14 percent are punctated, 7 percent are engraved, 4 percent are neck-banded, 2 percent have appliqued designs, and one decorated sherd has both incised and punctated designs. In the main, the brushed sherds derive from the body of everted rim jars with parallel or cross-hatched incised lines, but a brushed carinated bowl is also present (Table 5); this particular vessel has been refired. One characteristic decorative motif for the large jars at Carlisle include cross-hatched incised rims with a horizontal row of punctations on a clay-appliqued fillet at the body/rim juncture, and then vertical brushing on the body (see Figure 14).

Table 5. Ceramic Decorative

Elements.

\begin{tabular}{|c|c|c|c|c|c|}
\hline Decoration & Element & Surface & A & B & Vessel/Rim Forms \\
\hline Red-slipped & $\begin{array}{l}\text { Plain } \\
\text { Noded }\end{array}$ & & & $\begin{array}{l}5 \\
7\end{array}$ & $\begin{array}{l}\text { Carinated bowl } \\
\text { Bottle }\end{array}$ \\
\hline Neck-banded & $\begin{array}{l}\text { Regular crimped } \\
\text { Smoothed coil }\end{array}$ & 1 & 2 & 2 & Jar/Standing rim \\
\hline Appliqued & $\begin{array}{l}\text { Linear with } \\
\text { brushing/incision } \\
\text { Curvilinear } \\
\text { Curvilinear with } \\
\text { brushing } \\
\text { Linear with } \\
\text { punctation }\end{array}$ & $\begin{array}{l}1 \\
1\end{array}$ & & 1 & \\
\hline Engraved & $\begin{array}{l}\text { Diagonal and/or } \\
\text { triangles } \\
\text { Cross-hatched } \\
\text { Zoned Diagonal } \\
\text { Ladders } \\
\text { Broad-line } \\
\text { Curvilinear A } \\
\text { Curvilinear B } \\
\text { Below rim only }\end{array}$ & 2 & 1 & $\begin{array}{l}1 \\
1 \\
1\end{array}$ & $\begin{array}{l}\text { Standing rim } \\
\text { Bowl/Standing to } \\
\text { flaring } \\
\text { Carinated bowl/ } \\
\text { Standing-inverted } \\
\text { Carinated bowl/ } \\
\text { Standing rim } \\
\text { Carinated bowl } \\
\text { Shallow bowl }\end{array}$ \\
\hline
\end{tabular}


Table 5. cont.

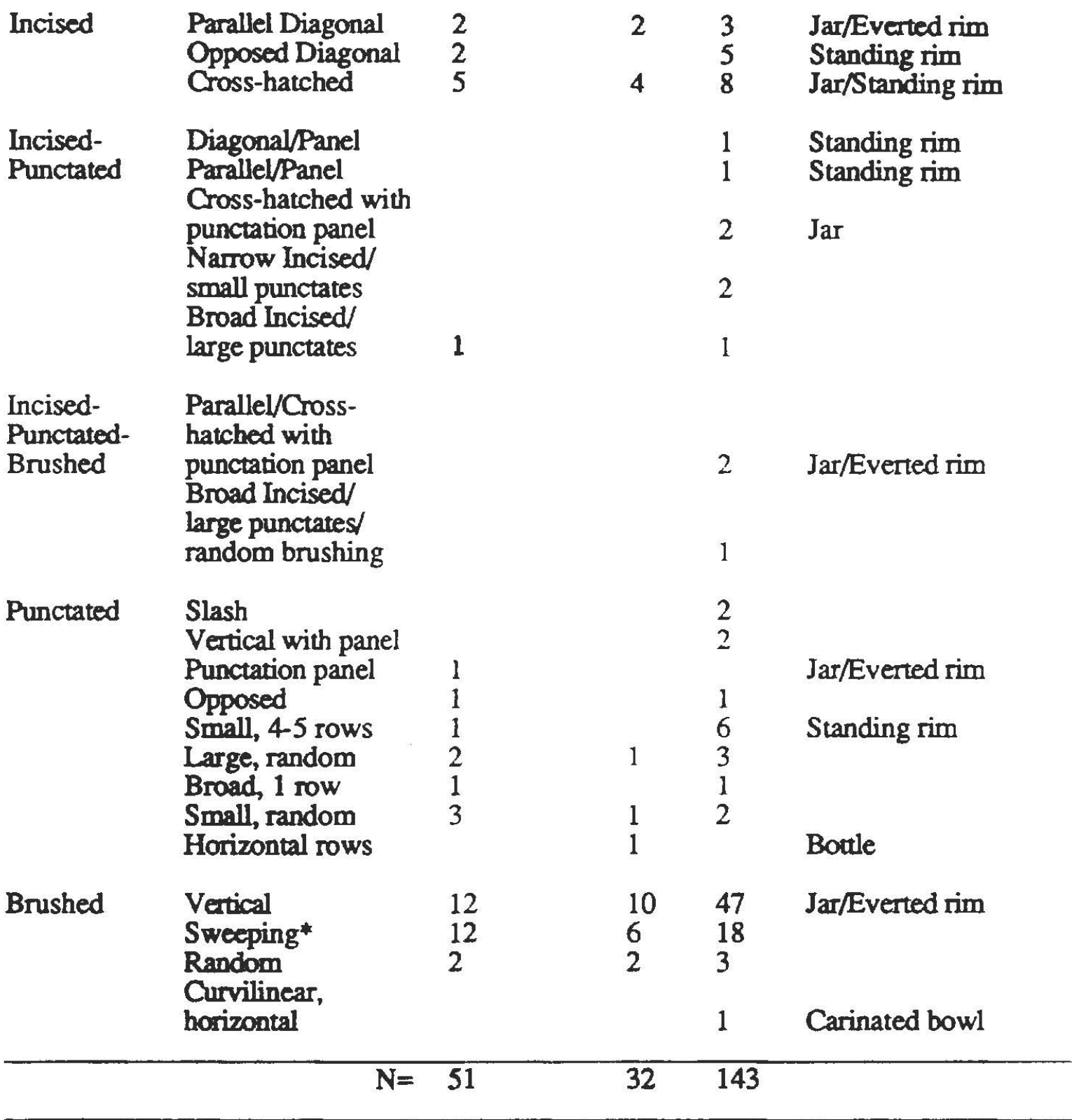

* Bone-tempered

Initially, we were inclined to associate the brushed sherds and brushed-incised jars with a limited Late Caddoan use of the site (Perttula 1986a). It has usually been assumed that brushing is a Late Caddoan vessel surface treatment in Northeast Texas, and the vertical association between the brushed sherds and the rest of the ceramics was poorly known from the 1975 work. The recovery in 1986 in Area B of Maxey Noded Redware bottle sherds found in association on the same occupational surface as a large rim section of an incised-brushed jar with the punctated fillet makes it evident that the brushed ceramics at Carlisle are not from a separate, Late Caddoan, component. 
The neck-banded sherds from Area A are from one or two possible LaRue Neckbanded vessels; the regularly crimped neck-banded coils have been partially smoothed but are still visible (Figure 6a-d). The appliqued sherds have linear and curvilinear designs, and in one case the applique ridge separates fine incised lines and parallel brushed elements on a jar form (see Figure 6e, g). The decorative treatment resembles that seen on Pease Brushed-Incised jars. The engraved sherds from Area $\mathrm{A}$ include a pendant triangle motif on a possible Ripley Engraved bowl, as well as curvilinear and "ladder" motifs from sherds in Unit 4S 2E. The engraved sherds are from straight rim bowls and carinated bowls (Figure 7).

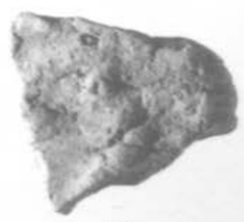

a

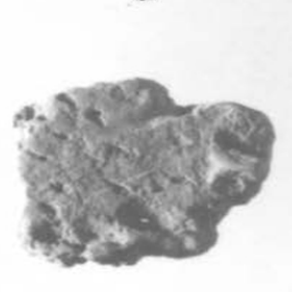

d

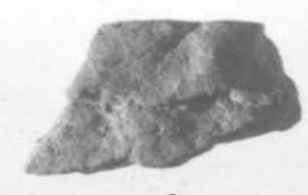

b

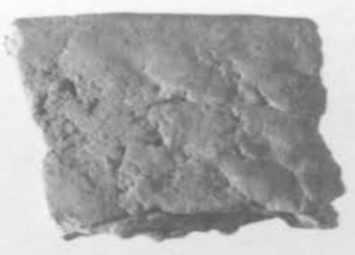

C

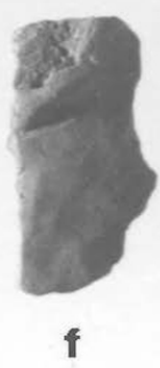

e
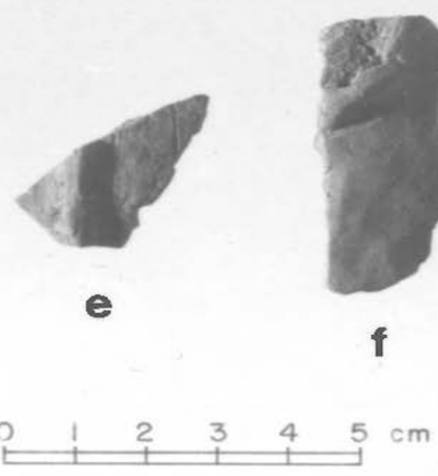

Figure 6. Neck-banded and appliqued sherds.

Incised sherds are relatively common in the Area A ceramic assemblage (see Table 5). Both cross-hatched and diagonal incised decorative elements are represented, with cross-hatched sherds accounting for 60 percent of the incised pieces (Figure 8). In general, the incised vessels are large jars with both standing and everted rims.

Unlike in Area B, incised-punctated or incised-punctated-brushed sherds are very rare in Area A at the Carlisle site. The single incised-punctated sherd from Area A has broad incised lines with large fingernail or tooled punctations. 

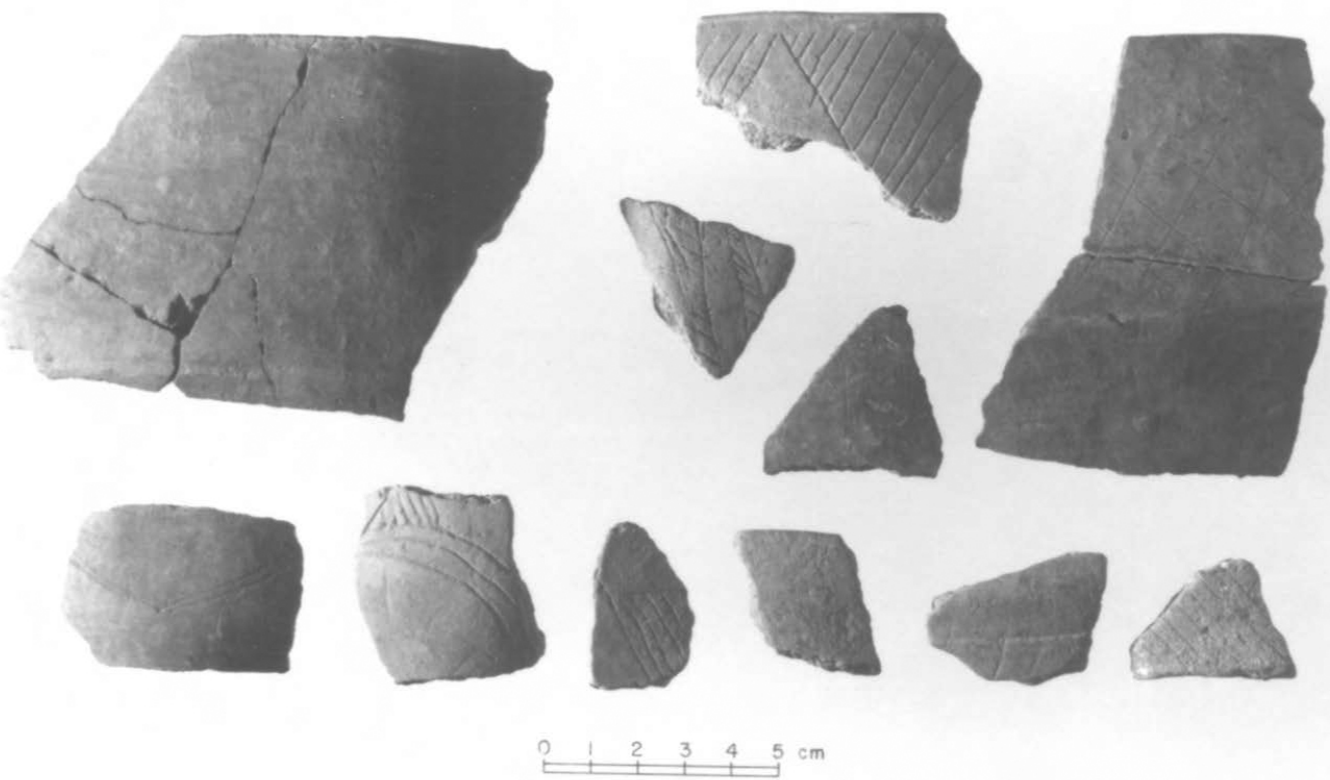

Figure 7. Engraved Sherds.
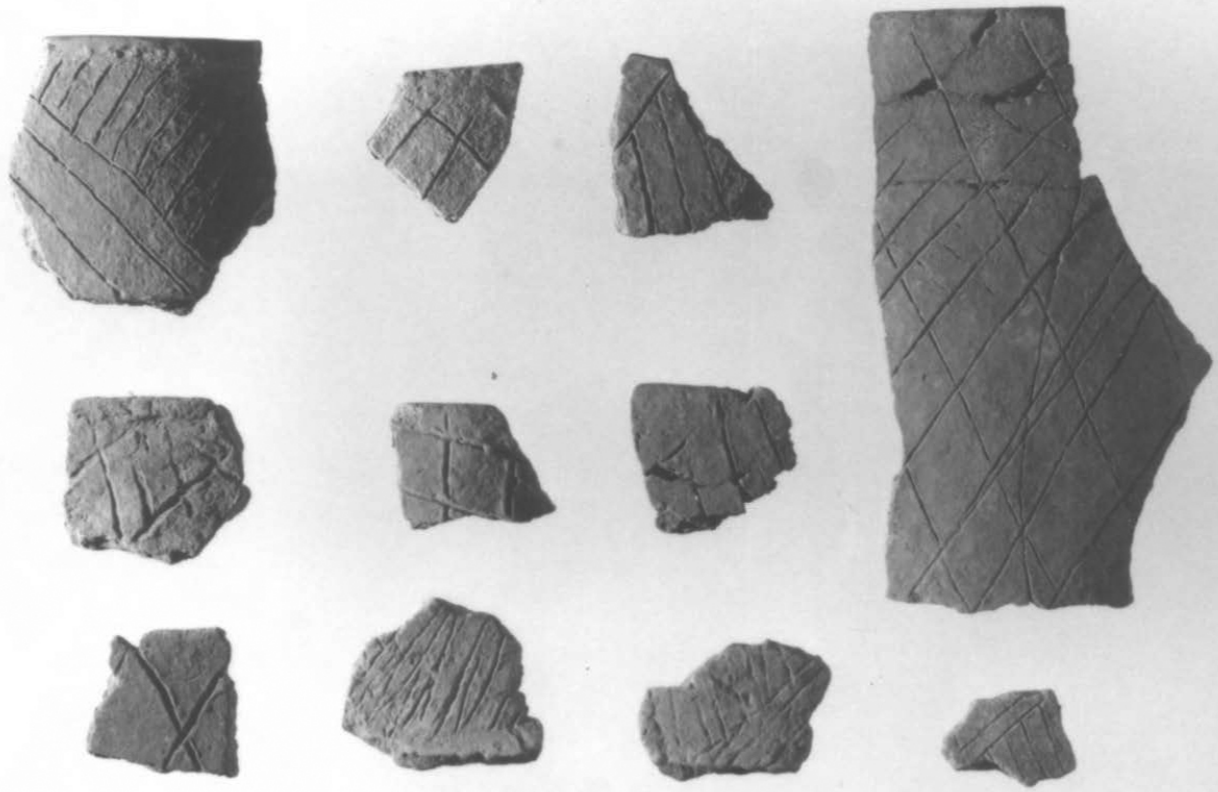

$\begin{array}{r}0 \quad 2 \quad 45 \\ 1 \quad 1 \quad 15 \\ \hline\end{array}$

Figure 8. Incised rim and body sherds. 
A variety of punctated sherds are seen in the Area A collection (see Table 5). Most occur in random orientation on the body and/or rim of standing and everted rim jars, with small, large, and broad sizes in the tool or finger punctations themselves (Figure 9). One sherd represents the punctated fillet panel at the base of the rim of large incised-brushed jars; this type of vessel decoration is apparently much more common in Area B (see Table 5). Rows of rim punctations are present on only three sherds from Area A, one from a standing rim jar and another from a bottle.
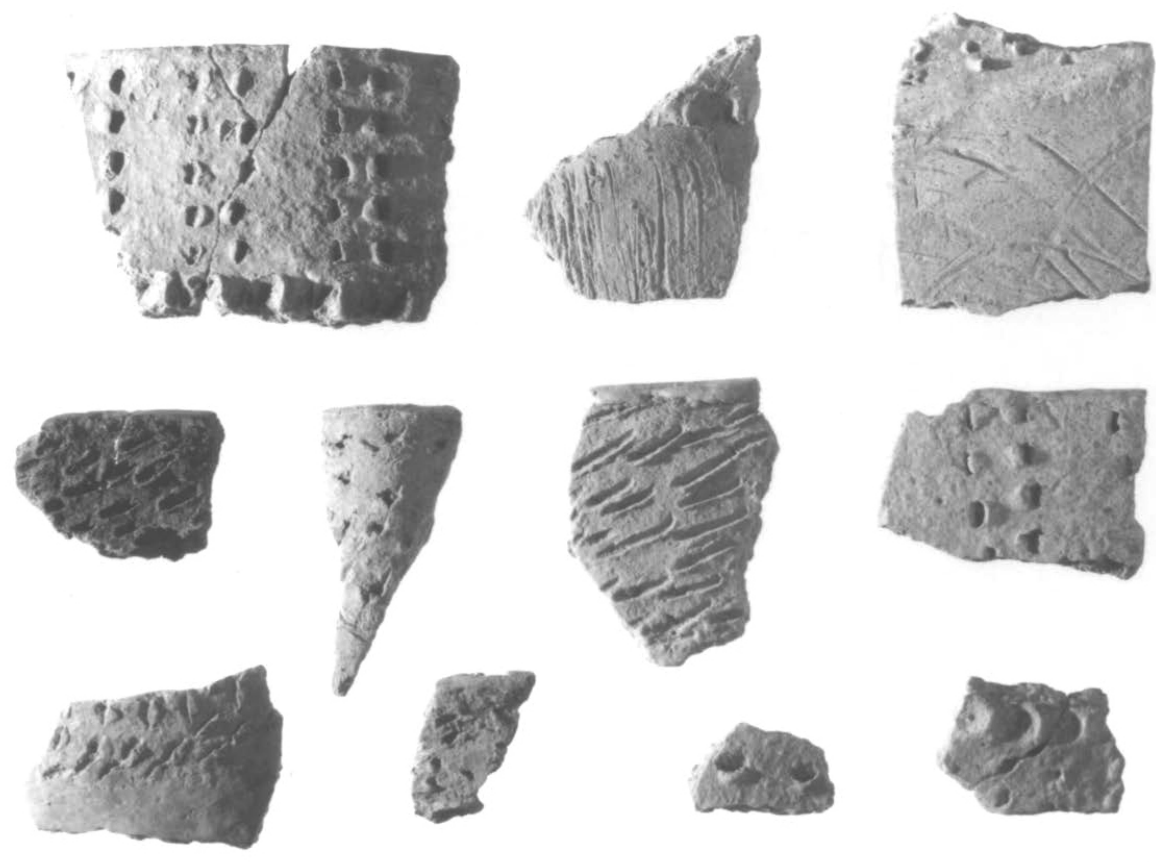

Figure 9. Punctated sherds.

Brushed sherds are well-represented in surface and excavated contexts at Area A. Generally, the brushed sherds represent the bodies of everted rim jars with incised and/or punctated rims (Figure 10). Over thirty sherds of a large cross-hatched incised/brushed jar were recovered from Unit 4S 7E. The vessel body brushing was commonly applied vertically with swaths of grasses before the vessel was fired, but sweeping, curvilinear brush marks account for about 40 percent of the brushed sherds (Figure 11). In a few instances, the brushing was rather randomly placed on the vessel body, and then partially obliterated through vessel finishing and/or use. 

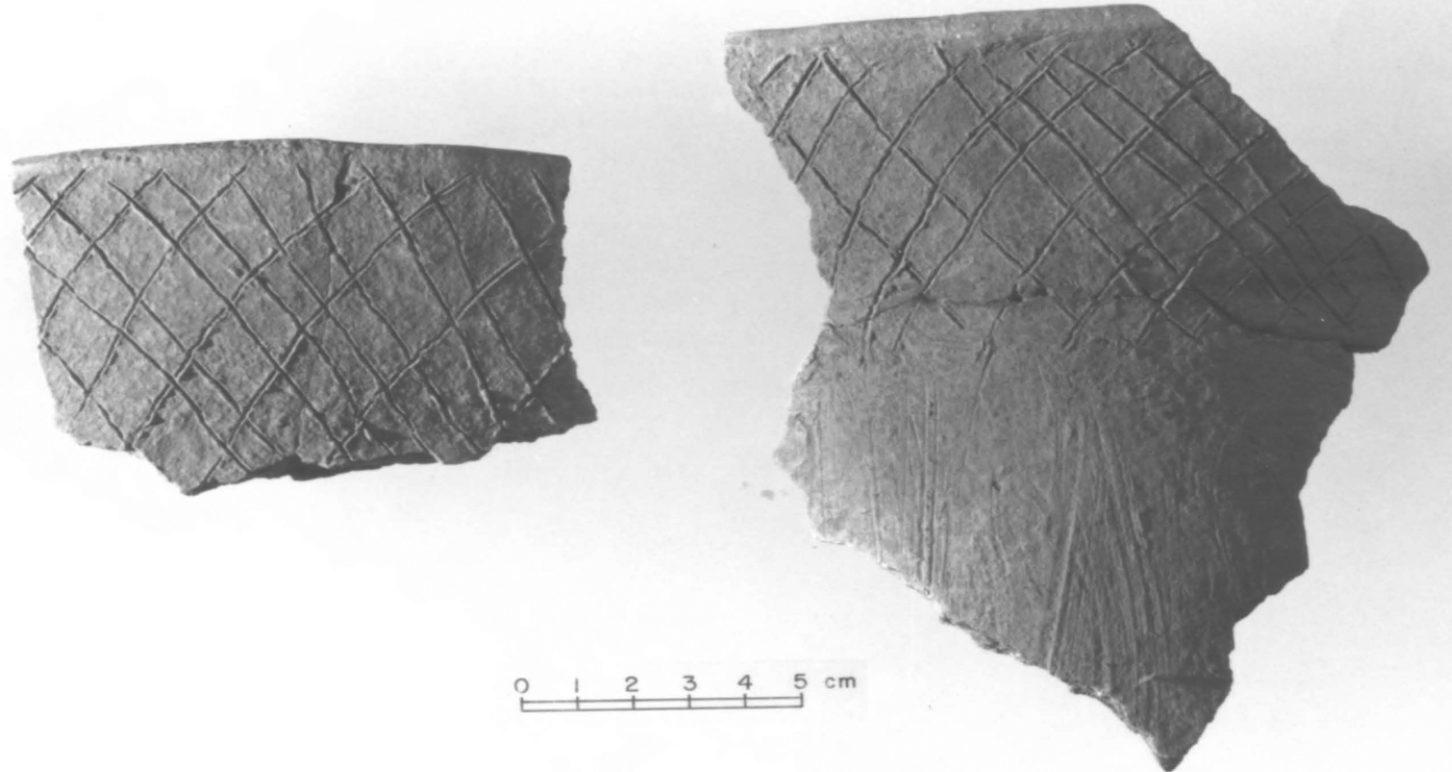

Figure 10. Large incised-brushed jar from Area A.
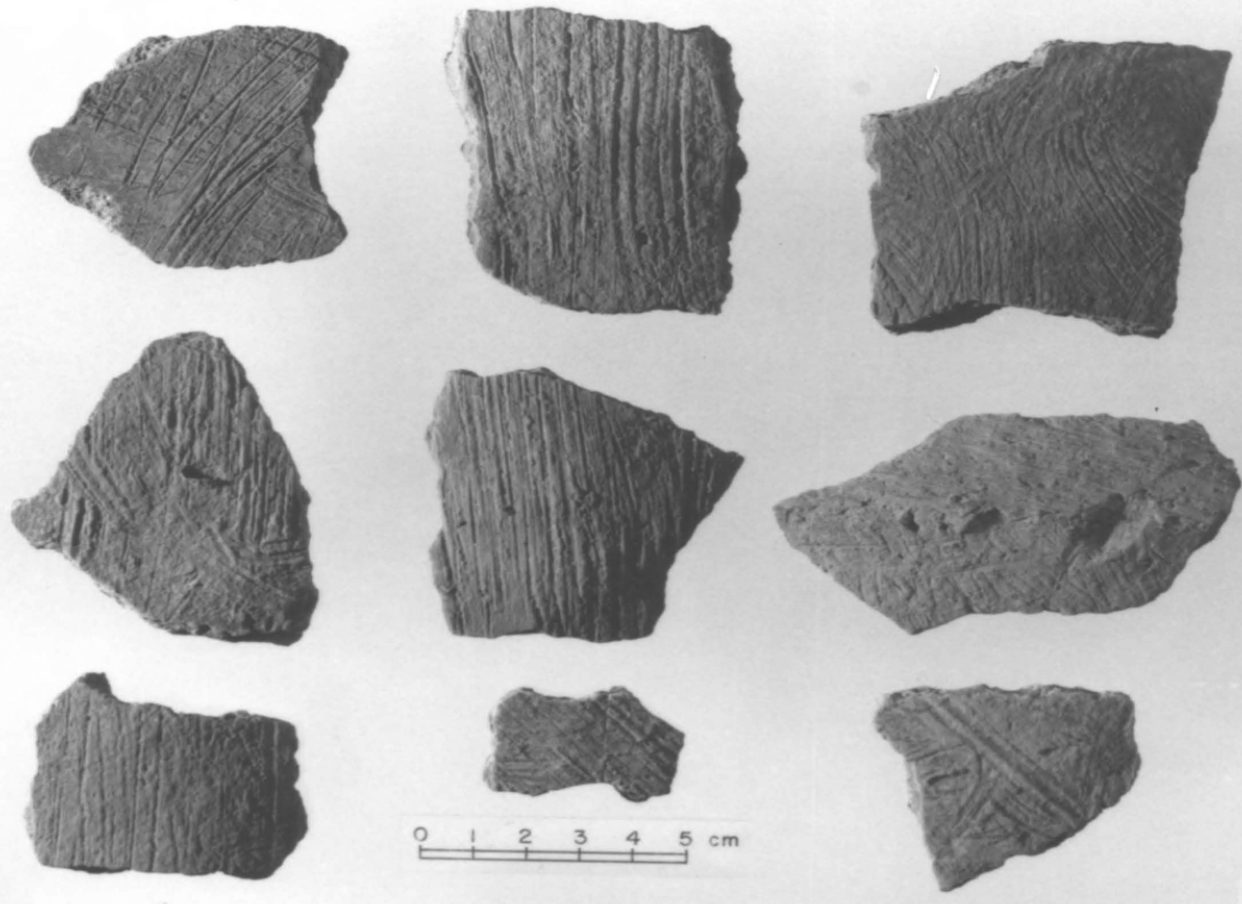

Figure 11. Brushed Sherds. 
The large incised-brushed jars frequently have smudging areas and patches of carbonized organic residue from their apparent use as cooking jars (e.g., Skibo 1992). Analyses of these residues are planned to identify what foodstuffs may have been cooked in these vessels, and thus gain information on vessel contents and possible uses (e.g., Heron and Evershed 1993).

Among the plain rims, standing and rolled rims were the two most common forms (Table 6). These derive from deep bowls and jars, and bowls or carinated bowls, respectively (Figure 12). Other plain rims have lip notching, small nodes, or are interior thickened. The latter type of rim form occurs on certain bowls and carinated bowls.

Table 6. Plain rims.

\begin{tabular}{lllll}
\hline Rim Type & Surface & Area A & Area B & Vessel Form \\
\hline $\begin{array}{l}\text { Standing-direct } \\
\text { Lip Notched }\end{array}$ & 6 & 2 & 4 & $\begin{array}{l}\text { Deep bowls } \\
\text { and jars }\end{array}$ \\
$\begin{array}{l}\text { Rim Node } \\
\text { Scalloped }\end{array}$ & 1 & 1 & 1 & \\
$\begin{array}{l}\text { Interior Thickened } \\
\text { Rolled }\end{array}$ & 3 & 2 & 1 & $\begin{array}{l}\text { Bowls and } \\
\text { carinated } \\
\text { bowls } \\
\text { Bowls and } \\
\text { carinated } \\
\text { bowls }\end{array}$ \\
\hline $\mathrm{N}=$ & 10 & 6 & 8 & \\
\hline
\end{tabular}

Characteristics of the Carlisle site, Area B ceramic assemblage include: (1) the motif of cross-hatched engraved triangles pendant from the rim, (2) horizontal engraving, (3) scalloped and interior thickened rims, (4) plain and Sanders Plain carinated bowls and Maxey Noded Redware bottles, and (5) a high frequency of diagonal and cross-hatched incised and incised-punctated vessels. Brushed sherds account for about 48 percent of the decorated sherds.

Plain and noded red-slipped sherds account for about eight percent of the Area B decorated sherds. The plain red-slipped sherds are from carinated Sanders Plain bowls. 
The red-slip was derived from pulverized hematite materials added to a clay wash, then applied to the vessel surface prior to firing. Petrographic and thin-section analyses indicate that these vessels were smoothed and burnished prior to the application of the slip, then burnished and polished after firing (Ferring and Perttula 1987).
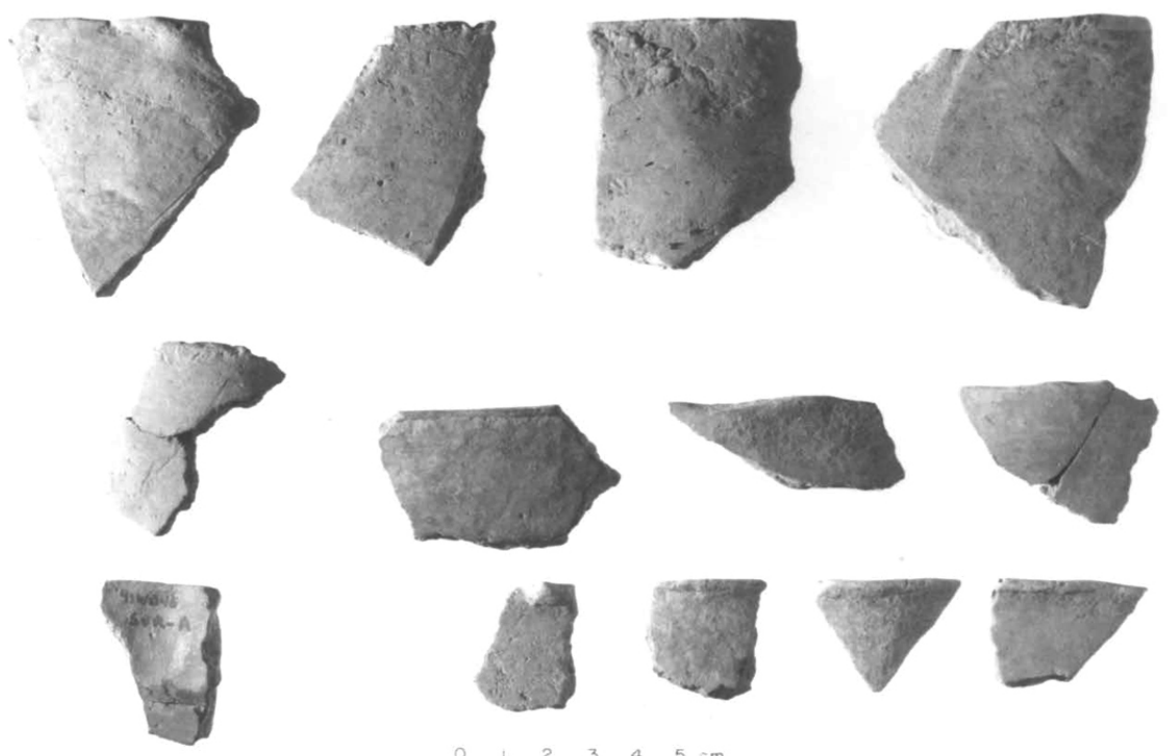

Figure 12. Plain Rims.

The red-slipped noded sherds are from two separate Maxey Noded Redware bottles. These are grog-tempered, squat, long-necked bottles decorated with parallel lines of applique nodes and a red slip added to the exterior vessel surface. The nodes are placed below the neck of the bottle and run vertically from there to just above the base in two to four sets of parallel lines. Another variety of Maxey Noded Redware has sets of fingernail punctates below the bottle neck to replace the nodes (Krieger 1946).

Maxey Noded Redware is an uncommon, but distinctive, Middle Caddoan ceramic type estimated to have been manufactured between about A.D. 1200-1400 (Thurmond 1985:189). At the Sanders site (41LR2), Maxey Noded Redware accounted for only about eight percent of the vessels (Krieger 1946:Table 5). The type appears to have been made by Caddoan peoples living in the area from the Upper Sabine River basin to the Middle Red River. 
Neck-banded and appliqued sherds from Area B account for 3.5 percent of the decorated sherds (see Table 5). The neck-banded sherds are from jars with standing rims. The neck-banding is characterized by regularly crimped, but unsmoothed, coils that overlap to create a shingle-like effect (see Figure 6a-d). In the Upper Sabine River basin neckbanded sherds resembling those from Carlisle have been noted at several sites in Lake Fork Reservoir (Bruseth and Perttula 1981:Table 5-3,5-8) and the Fred Yarbrough site in Van Zandt County (Johnson 1962:206).

Linear and curvilinear appliqued ridges occur on a few Area B sherds. The applique is typically added to vessel exteriors to divide parallel brushing on vessel bodies.

An interesting assortment of engraved bowl and carinated bowl sherds were recovered from Area B at the Carlisle site (see Table 5 and Figure 7). Decorative elements \#9 and \#10 are from Sanders Engraved bowls; one of the cross-hatched engraved rims has lip notching. Curvilinear and ladder engraved motifs are harder to characterize typologically, but similar decorative elements are seen on pottery from undated Caddoan sites in the Upper Sabine and Upper Neches river basins.

Decorative element \#11 is the most common engraved design in Area B. Represented by five sherds from one carinated bowl, the design consists of fine, zoned diagonal, engraved lines on the rim (Figure 13). Small excised triangles are nested in the angles of the diagonal engraved lines, and the broad lip has diagonal notched lines on it.

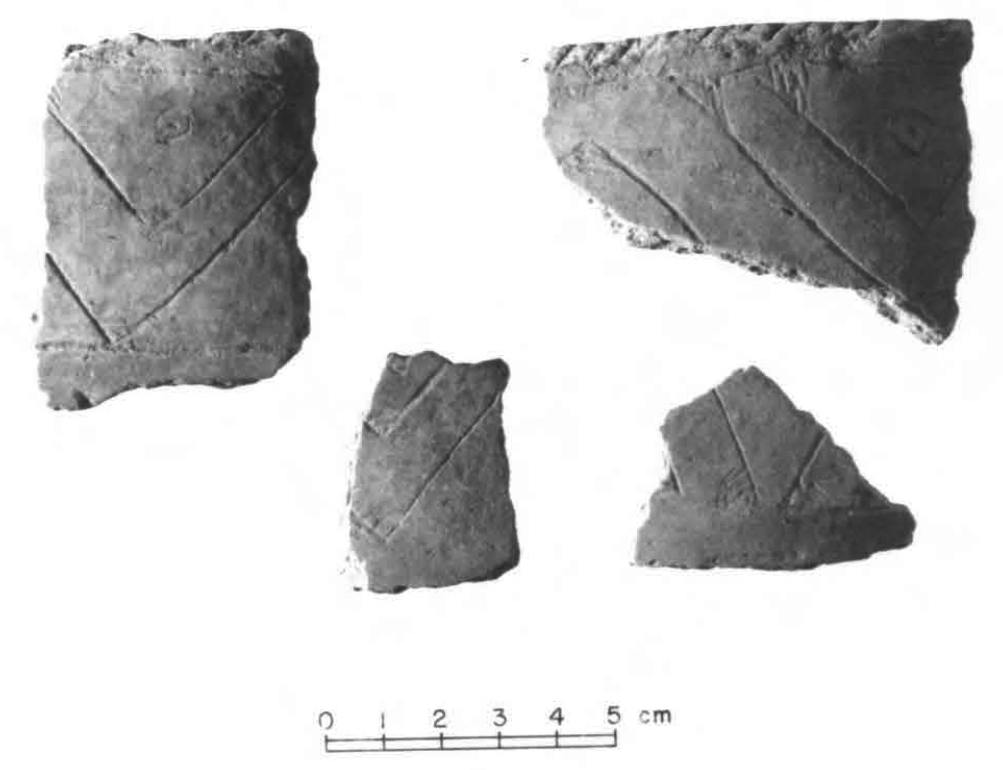

Figure 13. Engraved Vessel, Decorative element \#11. 
Both diagonal and cross-hatched incised sherds from straight and everted rim jars are represented in the Area B ceramic assemblage (see Figure 9). These are probably from Canton Incised and/or Maydelle Incised types.

The majority of the incised-punctated and incised-punctated with vertical brushed sherds, as well as a few of the punctated sherds (decorative element \#28), are from the most diagnostic Carlisle ceramics: the large jars with cross-hatched or parallel-opposed incised lines on the rim, a punctated applique fillet at the rim/body juncture, and a vertical brushed body (Figure 14). Other incised-punctated sherds consist of incised zones at the rim filled with either large or small circular punctations. These sherds are from standing rim jars.
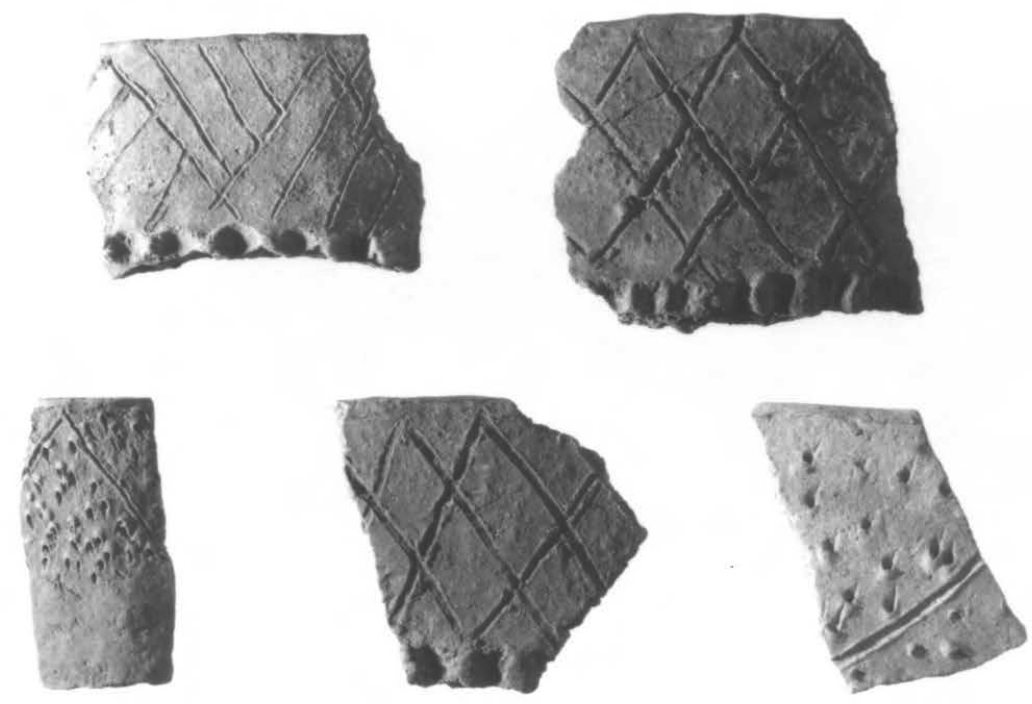

Figure 14. Incised-punctated sherds with appliqued panels.

In addition to the punctated panels on the aforementioned jars (see Table 5), other types of punctated sherds from Area B include a diagonal fingernail-slashed variety from a simple bowl, four to five horizontal rows of small punctations, and random punctations of various sizes (see Figure 9). The horizontal and random punctations are the two most frequent punctate elements. 
About 68 percent of the brushed sherds have vertical brushing marks on the bodies of everted rim jars (see Figure 11) decorated with broad-line incisions and punctations. Sweeping, curvilinear brushing is present on another 26 percent of the brushed sherds, and all these are from a distinctive vessel heavily tempered with bone (instead of the grog used with almost all the rest of the sherds from Carlisle). Finally, one carinated bowl was decorated with curvilinear and horizontal brushing marks on the rim.

Plain rims from Area B are predominantly standing and direct types (see Table 6). Lip-notched and scalloped-rim bowls are also present; these types of lip and rim treatment are notable in Middle Caddoan ceramic assemblages in the Upper Sabine River basin.

Small pieces of burned clay and daub were recovered from both Areas A and B at Carlisle (see Table 1). These are generally rounded and eroded pieces of clay that had been applied to the walls of structures, or were used to line hearths, and became fire-hardened through hearth cooking and/or structure burning. The daub has grass and stick impressions on them.

\section{FAUNAL ANALYSES}

A small but extremely diverse faunal assemblage was obtained in the excavations of Area A and B at the Carlisle site. Represented in the 258 identifiable specimens are eleven species of mammals, one bird species, five species of reptiles, and five fish species:

$\begin{array}{lll}\text { Mammals } & \text { Birds } & \text { Reptiles } \\ \text { Deer } & \text { Turkey } & \begin{array}{l}\text { Box turtle } \\ \text { Sofishell turtle } \\ \text { Swampljackrabbit }\end{array} \\ \begin{array}{l}\text { Fox Squirrel } \\ \text { Opossum }\end{array} & \text { Fish } & \begin{array}{l}\text { Red-eared turtle } \\ \text { Map turtle }\end{array} \\ \begin{array}{l}\text { Pocket Gopher } \\ \text { Cottonrat }\end{array} & \text { Bowfin } & \text { Slider } \\ \text { Raccoon } & \text { Drum } & \\ \text { Skunk } & \text { Bass/Sunfish } & \\ \text { Gray Squirrel } & \text { Gar } & \\ \text { cf.Dog } & \text { Catfish } & \\ \text { Vole } & & \end{array}$

Most of the faunal remains were recovered in the Area B midden deposits and Feature 1, with about 18 percent recovered from general proveniences in the 1975 investigations (most of this material is also from the Area B midden deposits). In terms of identifiable faunal elements, deer, box turtle, and drum are most common, followed by swamp or jackrabbit, opossum, red-eared turtle, and gar. Fish remains were particularly 
abundant in Feature 1, and in the middle part of the midden deposits (Table 7), as were reptile faunal elements. Mammal remains were particularly common in the general midden deposits.

Table 7. Faunal Analyses.

\begin{tabular}{|c|c|c|c|c|c|c|c|c|c|c|}
\hline & & & & & & ier & eve & fea & & \\
\hline Lv & $2^{*}$ & 3 & 4 & 5 & 6 & 7 & 8 & Fl & ST1 & General \\
\hline ID mammal & 0 & 7 & 8 & 6 & 1 & 0 & 0 & 2 & 0 & 12 \\
\hline ID bird & 0 & 0 & 0 & 0 & 0 & 0 & 0 & 0 & 0 & 1 \\
\hline ID reptile & 1 & 24 & 19 & 5 & 4 & 1 & 0 & 7 & 4 & 8 \\
\hline ID fish & 1 & 8 & 31 & 1 & 0 & 0 & 0 & 20 & 2 & 9 \\
\hline $\begin{array}{l}\text { UID non- } \\
\text { mammal }\end{array}$ & 0 & 0 & 0 & 2 & 0 & 0 & 0 & 0 & 0 & 0 \\
\hline UID medium & & & & & & & & & & \\
\hline $\begin{array}{l}\text { mammal } \\
\text { UID small }\end{array}$ & 0 & 3 & 9 & 0 & 0 & 0 & 0 & 0 & 0 & 16 \\
\hline $\begin{array}{l}\text { mammal } \\
\text { UID deer- }\end{array}$ & 0 & 1 & 0 & 0 & 0 & 0 & 0 & 0 & () & 0 \\
\hline sized & 1 & 8 & 5 & 4 & 1 & 0 & 1 & 0 & 1 & 0 \\
\hline UID mammal & 0 & 0 & 5 & 4 & 0 & 0 & 0 & 15 & 0 & 0 \\
\hline TOTALS & 3 & 51 & 77 & 22 & 6 & 1 & 1 & 44 & 7 & 46 \\
\hline
\end{tabular}

${ }^{*} \mathrm{Lv} .=$ levels, $\mathrm{F} 1=$ Feature $1, \mathrm{ST} 1=$ shovel test $1, \mathrm{ID}=$ identifed, and UID=unidentifed

In general character, the Carlisle faunal assemblage resembles that noted in Formative-Middle Caddoan archaeological sites in the Upper Sabine and Sulphur River basin of Northeast Texas (Perttula and Bruseth 1983; Perttula 1993). The assemblages are diverse, indicating that an assortment of upland, riverine, and aquatic species were exploited for food, with deer the most important mammal species, but turtles and fishes also were valued supplements to the Caddoan diet.

\section{MUSSEL SHELL ANALYSES}

A total of 133 identifiable mussel shells were recovered from the Area B midden. About 60 percent of the mussel shell were not identifiable to species, being represented only by pseudocardinal teeth. The most common mussel shell species included Amblema plicata, Quadrula quadrula, and Tritogonia verrucosa, but a number of other species were identified in the assemblage (Table 8). 
In general, the mussel shell species represented at the Carlisle site preferred muddy and slow moving water from medium-sized streams and rivers, although a few species preferred clear water with sandy bottoms. Both stream conditions can be found on both the Sabine River and Lake Fork Creek.

Table 8. Mussel Shell Analysis

$\begin{array}{lllllllllllll}\text { Species Level } 1 & 2 & 3 & 4 & 5: & 6 & 7 & 8 & 9 & \text { FEA. } 1 & \text { ST } 1 & \text { TOTAL }\end{array}$

Amblema plicata Quadrula quadrula Lampsilis hydiana Lampsilis radiata Lampsilis sp. Fusconia flava Obliquaria reflexus Tritogonia verrucosa Proptera purpurata

Pseudocardinal teeth

$\begin{array}{lllllllllllll}\text { Level } 1 & 2 & 3 & 4 & 5: & 6 & 7 & 8 & 9 & \text { FEA. } 1 & \text { ST } 1 & \text { TOTAL }\end{array}$

\section{SUMMARY}

This section summarizes the areal contexts and artifact associations from the Carlisle site based on 1970s surface collections and limited test excavations in 1975 and 1986. Since much of the material derives from surface collections, chronological and functional relationships between material remains are based in large measure upon the regional overview of artifact sequences for Northeast Texas proposed by Story (1990).

\section{AreaA}

The earliest occupation at the Carlisle site occurs on the upland projection (Area A). A small Middle Archaic period occupation (ca. $3500-2500$ B.C.) is represented by single examples of Bulverde and Wells projectile points, but a Late Archaic component with considerable subsurface depth is probably represented by the Yarbrough darts. One Yarbrough point was recovered in Unit $5 S 7 \mathrm{E}$ between $80-90 \mathrm{~cm}$ below surface.

Over 51 percent of all the dart points from the Carlisle site are Gary var. LeFlore (dated ca. 450 B.C. to A.D. 250 by Schambach [1982]) and var. Camden (ca. A.D. 250750) projectile points from Area A (see Table 2). This suggests that a fairly substantial 
Early Ceramic period occupation was present on the upland landform. No features were noted in the Area A excavations that relate to the Early Ceramic occupation, but much of the lithic debris, broken and finished tools, as well as the unifacial tools, probably can be associated with this occupation. Similar types of Early Ceramic period components are common in the Sabine and Sulphur River drainages, namely archeological deposits with large numbers of Gary points and other lithic tools, no ceramics, and no features (see Fields et al. 1992; Perttula et al. 1993). They appear to represent intensively, but intermittenly, utilized places where tool manufacture and refurbishing activities took place along with the procurement and processing of animal and plant food resources.

A more substantial Caddoan occupation is also present in Area A of the Carlisle site. The test excavations there encountered evidence that a structure probably stood on the upland projection: pieces of daub, a mud-dauber's nest, and several large sherds from brushed vessels that appear to have been refired during structure burning. Additionally, 31 sherds from a large incised/brushed jar were found on what appears to have been a living surface (or house floor?) at about $30-40 \mathrm{~cm}$ below surface (see Figure 11). Ninety percent of the vessel is present, and all of the sherds were recovered at a common depth in Unit $4 S$ 7E. The Area A Caddoan occupation probably represents a small farmstead or houseplace. with the Area B midden as its related trash dump; in fact, several sherds from both areas are conjoinable. Ceramic decorative similarities, and conjoined ceramic pieces, indicate that the Caddoan occupations were generally contemporaneous in Area A and B. The functional character of the Caddoan component at Carlisle is basically the same as that noted throughout the Upper Sabine River Basin.

\section{Area B}

This area contains a buried Caddoan midden dated to A.D. $1410+/-60$ (uncorrected). The midden was concentrated between $20-55 \mathrm{~cm}$ below surface and contained an abundance of mussel shell, faunal remains, carbonized seed fragments and nutshells, and ceramic sherds. ${ }^{1}$

The same types of ceramic decorative styles and vessel forms noted in Area A are present in Area B (see Table 5). By far the most common vessel form present was a cooking jar with an everted rim, and these were decorated with cross-hatched incised lines and punctated marks on the rim and vertically brushed bodies. The punctated marks were commonly applied on an appliqued fillet at the rim/body juncture (see Figure 12). Plain

1 This ecofactual material has not been thoroughly examined by a paleobotanist to date. 
carinated bowls and noded bottles with a hematite slip were represented only in Area B, while a variety of carinated and shallow bowls were found in both Area A and B that had mainly diagonal or cross-hatched engraved lines on them.

Scallorn and Bassett arrowpoints were recovered from both Areas A and B.

\section{CHRONOLOGICAL AND CULTURAL AFFILIATION OF THE CADDOAN OCCUPATION}

Because of the limited amount of archaeological research conducted on the Sabine River, the few available radiocarbon dates from the region, and the nature of the Carlisle site ceramic assemblage itself, the chronological and cultural affiliations of the Caddoan occupation at the site are not clear. Of particular significance is the high frequency of brushed cooking jars from the site.

Admittedly, the absolute percentage of brushed sherds is skewed due to the recovery of most of a large brushed-incised jar in situ in Area A; nevertheless, brushed sherds are common in the Area A and B ceramic assemblages (see Table 5). In nearby Three Basins subcluster sites of the Titus phase, like Goldsmith (41WD208) and Steck (41WD529), brushed utility wares are not particularly common (Thurmond 1990; Perttula, Skiles, and Yates in press), and engraved sherds are four to five times more common in sherd assemblages. In Lake Fork Reservoir, brushed utility wares are extremely rare, and occur only in Late Caddoan Titus phase contexts (Bruseth and Perttula 1981).

On the south side of the Sabine River, however, at sites such as Bryan Hardy (41SM55) (only $25 \mathrm{~km}$ from Carlisle) and Emma Sanford (41SM57), excavated by Mr. Sam Whiteside in the 1950s, brushed ceramics are quite common. Indeed, they are as frequent as any other decorated sherds in the ceramic assemblages. Sites 41WD245 and CXA (41WD507) on the north side of the Sabine River also have similar ceramic assemblages, particularly with respect to the numbers of brushed sherds and to some of the distinctive styles of engraved ceramics.

One of the engraved carinated bowls from Carlisle has an alternating triangular motif, and the lip has been regularly notched. A very similar carinated engraved bowl was uncovered in Burial 2 at the Bryan Hardy site by Sam Whiteside, along with a pinched pedestaled jar (Killough Pinched?) with strap handles, a plain bowl, and a tiny effigy bowl. The Bryan Hardy site is undated, but an initial examination of the excavated ceramic assemblage suggests a probable date range between about A.D. 1200-1400 (Perttula et al. 1986:81).

The A.D. $1410+/-60$ date from the Carlisle site seems consistent with the frequency of brushed ceramics, the presence of interior thickened rims, and the recovery of 
Maxey Noded Redware vessels from the site. A thermoluminescence (TLM) date of ca. A.D. 1280 (Alpha-2398) was obtained from an interior thickened Sanders Plain vessel at site 41WD117 on Big Sandy Creek, while another TLM date of ca. A.D. 1400 (Alpha2397) was secured on a Maxey Noded Redware vessel from another site in that drainage (Perttula et al. 1986:484). Similar interior thickened rims and lip notches have also been noted in the ceramics at the nearby Yarbrough (41VN6) and Limerick (41RA8) sites in the Upper Sabine River basin (Johnson 1962:Figure 23i; Duffield 1961:88).

Radiocarbon and TLM dates on Titus phase sites in the Upper Sabine River basin fall after about A.D. 1450 (Bruseth and Perttula 1981; Perttula et al. 1986), and it is possible that the occupation at Carlisle is not contemporaneous with the Titus phase. Perhaps, then, the affiliation of the Caddoan component at Carlisle lies with the heretofore poorly known occupations along and parallel to the Sabine River valley, and not with Titus phase Three Basin subcluster groups on Caney, Dry, and Big Sandy creeks in the Upper Sabine River basin, or with Sanders phase groups along the woodland border areas of Northeast Texas. Among the latter groups, settlements are distributed almost exclusively along tributaries and headwater areas of streams rather than to the major streams such as the Sabine River.

\section{CONCLUSIONS}

Caddoan middens roughly contemporaneous with the Carlisle site are known throughout the Upper Sabine River basin, all located on major streams like the Sabine River, Lake Fork Creek, and Caney Creek. These middens represent small habitation areas of fairly brief occupational span, and usually occur as related house and trash midden components at hamlets and probable farmsteads. Sites such as 41WD245, CXA (41WD507), Son Gibson (41WD1), Yarbrough, Area B (Johnson 1962), Taddlock (41WD482), and Spoonbill (41WD109) are only a few of the middens that have been excavated over the last 50 years in the region. The Carlisle Caddoan occupation generally resembles these sites in functional character, although the geomorphological context/location on the floodplain, the relative abundance of freshwater mussel shell, and the frequency of brushed sherds are specific differences between Carlisle and these other sites.

The Carlisle occupation represents a ca. A.D. 1400 small farmstead or houseplace that shares more similarities in ceramic styles with sites on the Sabine River than it does with generally contemporaneous Titus phase occupations upstream in the Lake Fork Creek drainage. Considerable refinement in cultural assemblage character and chronological 
sequences are still necessary, however, to understand more adequately the regional significance and social differentiation of the Caddoan use on this part of the Sabine River itself.

There is still a great need for the development of a reliable chronological framework for the Caddoan period occupations in the Upper Sabine River basin (see Story 1990). Isolating distinctive chronological components in space and time, combined with the identification of discrete single component assemblages, has to be done if archaeological units are to be related to regionally meaningful socio-cultural entities (Johnson 1987), and if we are to move past simple and basic settlement patterning questions.

Every effort should be made to investigate depositional contexts such as those at Carlisle where ecofactual remains might be preserved in cultural association. Certainly sites such as Taddlock, Spoonbill, and Carlisle exist where well-preserved subsistence data can be obtained, but these types of sites have not really been the focus of intensive study in the Upper Sabine River basin. Obviously, the systematic recovery and analysis of faunal and floral remains will contribute immeasurably to the full consideration of Upper Sabine River basin Caddoan lifeways.

Finally, an understanding of the regional paleoenvironmental and geomorphological record is an integral aspect of attempts to conceptualize prehistoric cultural adaptions. Moreover, these types of investigations may help to locate contexts such as those at Carlisle where buried archaeological deposits are present. Currently, the overall paleoenvironmental record for Northeast Texas is poorly known (Bryant and Holloway 1985; Story 1990), although the potential to recover significant information on Late Holocene environments for the basin is good (e.g., Perttula et al. 1986:322).

In each case, the potential exists with the data base already in hand to carry through exciting and useful research endeavors in Caddoan archaeology in the Upper Sabine River basin. The problem now is to turn that potential into reality by considering broader concepts of cultural change beyond simply basic temporal-spatial analyses. The Carlisle site contains much of the data we need to forge new understandings of Northeast Texas prehistory.

\section{REFERENCES CITED}

Bruseth, James E. and Timothy K. Perttula

1981 Prehistoric Settlement Patterns at Lake Fork Reservoir. Report No. 2. Texas Antiquities Committee, Texas Antiquities Permit Series. Texas Historical Commission, Austin. 
Bryant, Vaughn M. and Richard G. Holloway

1985 A Late Quaternary Paleoenvironmental Record of Texas: An Overview of the Pollen Evidence. In Pollen Records of Late-Quaternary North American Sediments, edited by Vaughn M. Bryant and Richard G. Holloway, pp. 3970. American Association of Stratigraphic Palynologists Foundation, Dallas.

Bureau of Economic Geology

1965 Geologic Atlas of Texas, Tyler Sheet. Bureau of Economic Geology, The University of Texas, Austin.

Duffield, Lathel F.

1961 The Limerick Site at Iron Bridge Reservoir, Rains County, Texas. Bulletin of the Texas Archeological Society 30:51-116.

Ferring, C.Reid and Timothy K. Perttula

1987 Defining the Provenance of Red Slipped Pottery from Texas and Oklahoma by Petrographic Methods. Journal of Archaeological Science 14:437-456.

Fields, Ross C., Eloise F. Gadus, L. Wayne Klement, C. Britt Bousman, and Jerrilyn B. McLerran

1992 Excavations at the Tick, Spike, Johns Creek, and Peerless Bottoms Sites, Cooper Lake Project, Delta and Hopkins Counties, Texas. Reports of Investigations No. 91. Prewitt and Associates, Inc., Austin. Review Draft.

Heron, Carl and Richard P. Evershed

1993 The Analysis of Organic Residues and the Study of Pottery Use. In Archaeological Method and Theory, Volume 5, edited by Michael B. Schiffer, pp. 247-284. The University of Arizona Press, Tucson.

Johnson, Leroy, Jr.

1962 The Yarbrough and Miller Sites of Northeastern Texas, with a Preliminary Definition of the LaHarpe Aspect. Bulletin of the Texas Archeological Society 32:141-284.

1987 A Plague of Phases:Recent Sociocultural Taxonomy in Texas Archeology. Bulletin of the Texas Archeological Society 57:1-26.

Krieger, Alex D.

1946 Culture Complexes and Chronology in Northern Texas. Publication No. 4640. The University of Texas, Austin.

Perttula, Timothy K.

1984 Patterns of Prehistoric Lithic Raw Material Utilization in the Caddoan Area: The West Gulf Coastal Plain. In Prehistoric Chert Exploitation- Studies from the Midcontinent, edited by B.M. Butler and E.E. May, pp. 129-148. Occasional Paper No. 2. Center for Archaeological Investigations, Southern Illinois University, Carbondale.

1986 Archeological Reconnaissance in the Waters Bluff and Upper Little Cypress Reservoirs, Gregg, Harrison, Smith, Upshur, and Wood Counties, Texas. Report submitted to the Bureau of Reclamation by Prewitt and Associates, Inc., Austin. 
Perttula, Timothy K.

1986a The Carlisle Site (41WD46) in the Upper Sabine River Basin. Paper presented at the 1986 Caddo Conference, Little Rock, Arkansas.

1993 The Development of Agriculture in Northeast Texas before A.D. 1600. In Archeology of the Eastern Planning Region, Texas: A Planning Document, edited by Nancy Adele Kenmotsu and Timothy K. Perttula. Cultural Resource Management Report No. 3. Department of Antiquities Protection, Texas Historical Commission, Austin. In press.

Perttula, Timothy $\mathrm{K}$. and James E. Bruseth

1983 Early Caddoan Subsistence Strategies, Sabine River Basin, East Texas. Plains Anthropologist 28:9-21.

Perttula, Timothy K., Bob D. Skiles, and Bonnie C. Yates

in press The Goldsmith Site (41WD208): Investigations of the Titus phase in the Upper Sabine River Basin, Northeast Texas. Bulletin of the Texas Archeological Society 61.

Perttula, Timothy K., Ross C. Fields, James E. Corbin, and Nancy A. Kenmotsu

1993 The Emergence of Sedentism in the Northeast Texas Archeological Region, ca. 500 B.C. to A.D. 1000. In Archeology of the Eastern Planning Region, Texas: A Planning Document, edited by Nancy Adele Kenmotsu and Timothy K. Perttula. Cultural Resource Management Report No. 3. Department of Antiquities Protection, Texas Historical Commission, Austin. In press.

Perttula, Timothy K., Bob D. Skiles, Michael B. Collins, Margaret C. Trachte, and Fred Valdez, Jr.

1986 "This Everlasting Sand Bed": Cultural Resources Investigations at the Texas Big Sandy Project, Wood and Upshur Counties, Texas. Reports of Investigations No. 52. Prewitt and Associates, Inc., Austin.

Schambach, Frank F.

1982 An Outline of Fourche Maline Culture in Southwest Arkansas. In Arkansas Archeology in Review, edited by N.L. Trubowitz and M.D. Jeter, pp. 132197. Arkansas Archeological Survey, Research Series No. 15. Fayetteville.

Skibo, James

1992 Pottery Function: A Use-Alteration Perspective. Plenum Press, New York.

Skiles, Bob. D., James E. Bruseth, and Timothy K. Perttula

1980 A Synthesis of the Upper Sabine River Basin Culture History. The Record (Newsletter of the Dallas Archeological Society) 36 (1):1-12.

Story, Dee Ann

1990 Cultural History of the Native Americans. In The Archeology and Bioarcheology of the Gulf Coastal Plain, by Dee Ann Story, Janice A. Guy, Barbara A. Burnett, Martha Doty Freeman, Jerome C. Rose, D. Gentry Steele, Ben W. Olive, and Karl J. Reinhard, pp. 163-366. Arkansas Archeological Survey, Research Series No. 38. Fayetteville. 
Sullivan, Alan P. and Kenneth C. Rozen

1985 Debitage Analysis and Archaeological Interpretation. American Antiquity 50:755-779.

Thurmond, J. Peter

1985

Late Caddoan Social Group Identifications and Sociopolitical Organization in the Upper Cypress Basin and Vicinity, Northeastern Texas. Bulletin of the Texas Archeological Society 54:185-200.

$1990 \quad$ Archeology of the Cypress Creek drainage basin, Northeastern Texas and Northwestern Louisiana. Studies in Archaeology No. 5. Texas Archeological Research Laboratory, The University of Texas, Austin.

Wilson, A.M. and A.T. Jackson

1930 Reconnaissance in Wood County, Texas, August 10 to 24, 1930: Field Notes. MS on file, Texas Archeological Research Laboratory, The University of Texas at Austin. 


\title{
Caddoan Mound Sites in the Sabine River Basin \\ of Northeast Texas
}

\author{
Timothy K. Perttula \\ Department of Antiquities Protection \\ Texas Historical Commission \\ Austin, Texas 78711
}

\begin{abstract}
Caddoan tradition mound sites in the Sabine River basin of Northeast Texas, and Northwest Louisiana, likely represent some of the better archaeological evidence for the existence of social and settlement hierarchical differentiation during the late prehistory (ca. A.D. 800-1600) of the area. Both structural and burial mounds are known in a ca. 300 kilometer stretch of the Sabine River basin between Lake Tawakoni and Toledo Bend Reservoir, particularly being constructed and used during the period between ca. A.D. 1000-1400. The larger mound sites, containing multiple mounds and associated settlements, are apparently regional civic-ceremonial centers. However, whether a hierarchy of contemporaneous civic-ceremonial centers existed at any time during the Caddoan settlement of the Sabine River basin is still a matter of speculation because only one (the Hudnall-Pirtle site) of the known mound centers have been dated by absolute methods.
\end{abstract}

\section{Introduction}

Mound groups constructed and used by Caddoan groups represent a unique but poorly studied cultural resource in Northeast Texas. Important prehistoric Caddoan social, ceremonial, and political centers in the region may be represented by as many as 105 single and multiple mound sites (Perttula 1993a, 1993b). Both structural and burial mounds occur as distinct mound types, with burial mounds the mortuaries for the elite members of Caddoan cultural groups, and the structural mounds served as platforms for the 
construction (and deliberate destruction) of specialized structures or dwellings (Story 1990:340-341). The study of the civic and ceremonial nature of the Caddoan mound centers is important for understanding the development of Caddoan culture because they can provide us with data on how the emergence and elaboration of socio-political complexity is related to cultural change over time in the region.

Although Caddoan mound sites have been reported in the Sabine River Valley since the early 1900s (Pearce 1920), the only professional investigations of such sites has been primarily restricted to relatively unsophisticated trenching of the mound deposits carried out by A.T. Jackson in the 1930s for the University of Texas (see Guy 1990). Since that date, new mound sites have been reported (see Malone 1972; Webb et al. 1969; Perttula et al. 1986; Jensen 1968a, 1968b; Perttula and Skiles 1987; Bruseth 1991), but with the exception of investigations at Coral Snake (16SA48) [an Early Ceramic Period mound] and Hudnall-Pirtle (41RK4) [Jensen 1968a, 1968b; Bruseth 1991), these have been only cursorily examined.

The present research on Caddoan mound groups in the Sabine River Valley and tributaries is thus a first step towards developing a sound data base on the location, character, contextual integrity, and current preservation condition of known and potential mound sites, especially the important multiple mound groups. This data base serves as an integral part of the Northeast Texas Preservation Plan for archeological resources (e.g., Kenmotsu and Perttula 1993), will help to document and support National Register nominations for mound complexes in the Sabine River Valley, and will be important for focusing study on the broader questions concerning the complex socio-political developments of prehistoric Caddoan societies in the Sabine River Valley (cf. Story 1990; Perttula 1989a, 1993a).

The records and collections at the Texas Archeological Research Laboratory and the University of North Texas were reviewed, and interviews were conducted with local avocational archaeologists and collectors, to develop an initial inventory of known and 
potential Caddoan mound groups in the Sabine River Valley. Based on leads gathered in those repositories, such as landowner names of farms provided in manuscripts and land survey field notes, a cursory examination of county records and archives (such as the land deed records of the 1920s-1930s), as well as local histories (e.g., Woldert 1932), the inventory process was considered to be relatively comprehensive for Northeast Texas. Information on selected Northwest Louisiana mound sites in the Sabine River Valley was supplied by the Louisiana Department of Culture, Recreation and Tourism, Office of Cultural Development, Division of Archaeology, and from published sources (e.g., Girard 1991).

This work was supplemented by relocating known and recorded mound sites in the Sabine River Valley. This was done to obtain more detailed locational information on the mounds, as well as gather data on associated material culture assemblages. The multiple mound sites, or potential multiple mound sites, known in the Sabine River Valley were given precedence in guiding the survey effort because of their regional archaeological significance (Perttula 1989a:1, 4).

Limited subsurface testing was conducted at four mound sites (41PN8, 41SM54, 41SY46, and 41UR30) to obtain, if feasible, temporally and functionally diagnostic prehistoric artifacts from selected sites and/or specific areas within sites, and also to obtain suitable materials such as charcoal or thermoluminescence samples for dating (see Perttula 1989a:35-40). Where possible, surface collections were made at individual sites, and notes were maintained for each site specifying the location and extent of surface-exposed artifactual materials.

\section{Discussion of Results}

A total of 37 possible mound sites have been identified in the Sabine River Basin of Northeast Texas and Northwest Louisiana, three in Louisiana and the remainder in Texas (see also Pertula 1989a:43-91; Girard 1991). They are distributed over a ca. 300 kilometer 
stretch of the Sabine River Valley and its tributaries, from Lake Tawakoni in the west to below Toledo Bend Reservoir in the south (Figure 1). The potential and known mound sites represent a significant span of the regional prehistoric archaeological record, from ca. 200 B.C. to ca. A.D. 1600 . However, approximately 90 percent of the mounds appear from the aboriginal ceramic evidence to date after ca. A.D. 800 , and thus can be assigned to the Late Prehistoric Caddoan Period Tradition (Table 1).

One of the earliest episodes of mound exploration in the Sabine River Valley of Northeast Texas took place ca. 1865, and was described in the WPA slave narratives: ...we niggers wuz helping dig in de big ole Indian mound down near the Sabine River...De ole mound is down near de ole Alligator Hole in de Sabine River bottom. It is one of de ole Civil War plantations, but is all growed up wid trees now. Us niggers wuz digging a hole in de top of de ole mound. It wuz easy digging, as it wuz white sand all de way down. We wuz digging a hole twelve feet square right on de top of dis mound. We wuz down in de mound 'bout 22 feet...De last bucket dey brought up I'se noticed lots of little white balls in de sand. Fse picked up a few of dem and wuz looking at dem wen de sand come off, and I saw it wuz man's teeth. I tol' de white man who had us wo'kin' in de mound I was not goin' to work in dat place any mo' for it wuz a grave yard...De teeth dat we got wuz all we found in dat ole place (Rawick 1979:2936-2937).

A.T. Jackson and his associate A.M. Wilson investigated several mounds in Van Zandt and Wood County in the early 1930s (including 41VN2, 41VN7, I.M. Counts (no site trinomial was assigned to this mound), 41VN13, 41WD7, 41WD9, and 41WD11), and avocationalist Sam Whiteside, from Tyler, Texas, excavated at mound sites 41SM54, 41SM55, and 41UR30 in the latter 1950s-early 1960s in Upshur and Smith counties 
g

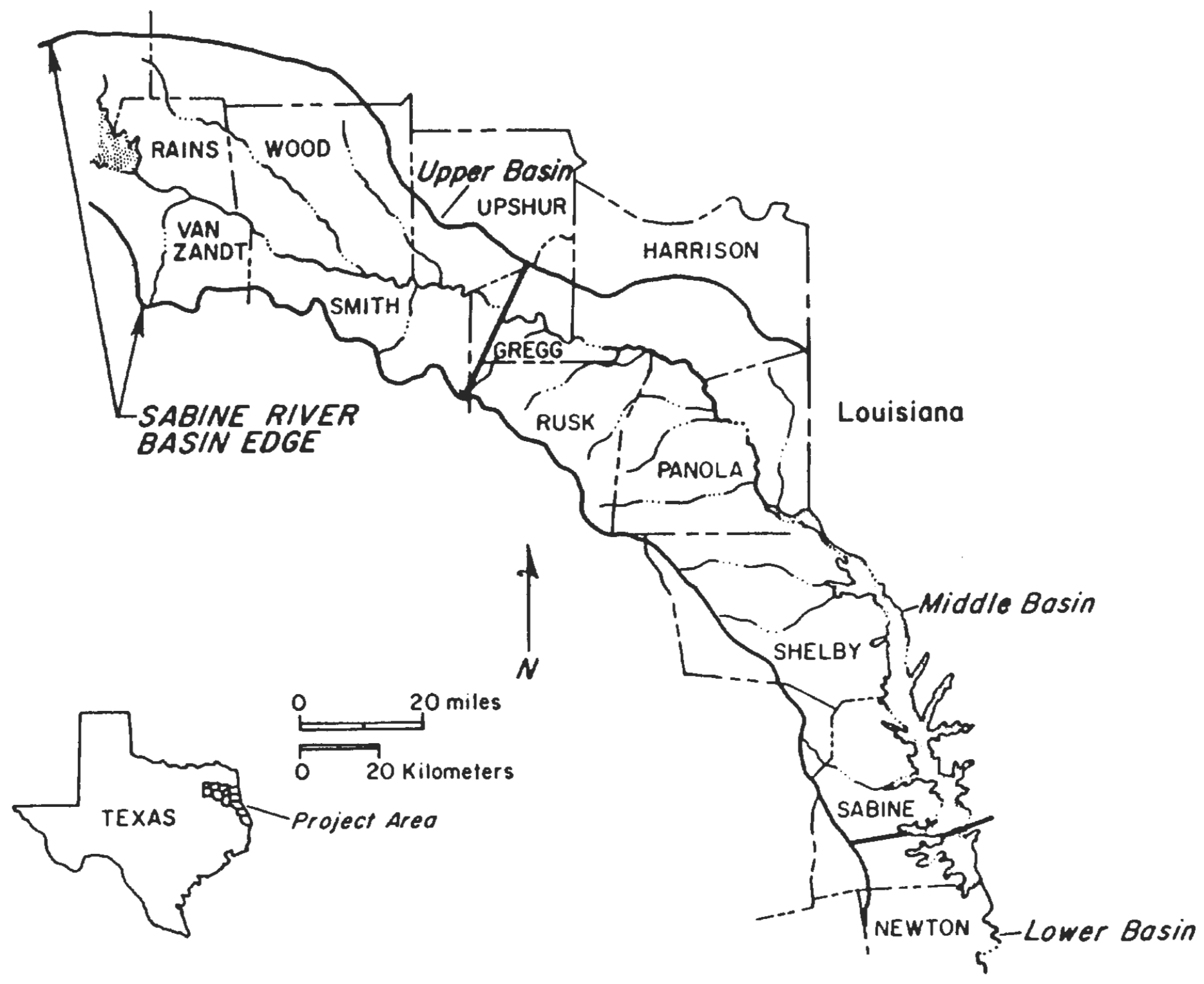

Figure 1. The Sabine River Basin, Northeast Texas. 
Table 1. Tabulation of known or Potential Mound Sites in the Sabine River Valley, Northeast Texas and Northwest Louisiana.

\begin{tabular}{ccccccccccc}
16 & 16 & 16 & 41 & 41 & 41 & 11 & 11 & 41 & 11 & 41 \\
OSIO & SA1O & SA48 & HS4 & HSIS & HS233 & HY16 & PHI & PHB & RA31 & RAJ8 \\
\hline
\end{tabular}

\begin{tabular}{|c|c|c|c|c|c|c|c|c|c|c|c|}
\hline Landf orm & $\mathrm{Qt}^{*}$ & Qt & Qt & $\mathbf{F l}$ & Up & $U_{p}$ & $\mathbf{F} \mathbf{1}$ & 11 & MI & at & Up \\
\hline Dralnage & Sabine & Caney & Sabine & $\begin{array}{l}\text { Yerds } \\
\text { Creek }\end{array}$ & $\begin{array}{l}\text { Storkey } \\
\text { Creek }\end{array}$ & $\begin{array}{l}\text { Mat ley } \\
\text { Creek }\end{array}$ & Sebine & Sablne & Sebine & $\begin{array}{c}\text { Oig } \\
\text { Creek }\end{array}$ & Sabine \\
\hline Rank & 1 & 2 & 1 & 3 & 3 & 2 & 1 & 1 & 1 & $2 / 3$ & 1 \\
\hline \multicolumn{12}{|l|}{ Distance } \\
\hline $\begin{array}{l}\text { to Sablne } \\
\text { River (km) }\end{array}$ & 1.5 & 5.0 & 0.5 & 10 & 8 & 1.6 & 0.9 & 0.1 & 1.2 & 7.0 & 1.0 \\
\hline \multicolumn{12}{|l|}{ No. of } \\
\hline Mounds & 1 & 1 & 1 & 4 & 2 & 4 & 1 & 1 & 1 & 2 & 1 or 2 \\
\hline Mound Ares & unknown & 256 & 900 & 162 & unknown & unknown & unknown & 100 & 110 & 500 & $224^{\circ 1}$ \\
\hline Est Imated & unknown & 461 & 2100 & unknown & unknown & unknown & unknown & 1000 & 110 & 500 & $224^{* 1}$ \\
\hline & & & ca. 1200 & A.D. & A.D. & A.0. & & & A.O. & A.D. & A.D. \\
\hline $\begin{array}{l}\text { Age of } \\
\text { Component }\end{array}$ & $\begin{array}{l}\text { A.D. } \\
100-800\end{array}$ & unknown & $\begin{array}{l}\text { B.C. . } \\
\text { A.0. } 100\end{array}$ & $\begin{array}{l}-1400- \\
1600^{\circ}\end{array}$ & $\begin{array}{l}1400- \\
1600^{+}\end{array}$ & $\begin{array}{l}1400- \\
1600^{\circ}\end{array}$ & unknown & unknown & $\begin{array}{l}1000- \\
1600\end{array}$ & $\begin{array}{l}1000- \\
1100\end{array}$ & $\begin{array}{l}1000- \\
1400\end{array}$ \\
\hline Mound & & & & $x$ & $?$ & 1 & & & & $?$ & $?$ \\
\hline \multicolumn{12}{|l|}{ Structures } \\
\hline \multicolumn{12}{|l|}{ Mound } \\
\hline Burlals & & & $x$ & & & & & & & & \\
\hline
\end{tabular}


Table 1. Tabulation of known or Potential Mound Sites in the Sabine River Valley, Northeast Texas and Northwest Louisiana (continued).

\begin{tabular}{|c|c|c|c|c|c|c|c|c|c|c|c|}
\hline & $\begin{array}{r}41 \\
\text { RK3 }\end{array}$ & $\begin{array}{r}11 \\
\text { RK4 }\end{array}$ & $\begin{array}{c}41 \\
\text { SM54 }\end{array}$ & $\begin{array}{c}41 \\
\text { SN55 }\end{array}$ & $\begin{array}{c}11 \\
\text { SM62 }\end{array}$ & $\begin{array}{c}41 \\
\text { SY15 }\end{array}$ & $\begin{array}{c}11 \\
\text { SY27 }\end{array}$ & $\begin{array}{c}115 Y \\
42\end{array}$ & $\begin{array}{c}41 S Y \\
46\end{array}$ & $\begin{array}{c}\text { A1UR } \\
30\end{array}$ & $\begin{array}{l}11 \\
\text { VN2 }\end{array}$ \\
\hline \multirow[t]{3}{*}{ Landform } & $Q t$ & $Q t$ & Up & Up & F1 & Up & Up & $Q t$ & Up/Qt & $Q t$ & FI \\
\hline & & & & & & & & & Beau - & & \\
\hline & Mart ín & & Village & Ray & Simpson & & Chicken & Bayou & champ & & M111 \\
\hline Dralnage & Creek & Sabine & Creek & Creek & Creek & Sabine & Bayou & Siepe & Creek & Sabine & Creek \\
\hline Rank & 2 & 1 & 2 & 3 & 3 & 1 & 4 & 2 & 3 & 1 & 2 \\
\hline \multicolumn{12}{|l|}{ Distance } \\
\hline River(km) & 25 & 1.0 & 5.5 & 14.0 & 15.0 & 2.0 & 30 & 10 & 30 & 0.1 & 18 \\
\hline \multicolumn{12}{|l|}{ Wo. of } \\
\hline Mounds & 1 & 6 & 7 & 1 & 1 & 2 & 1 & 1 & 1 or 2 & 4 & 1 \\
\hline \multicolumn{12}{|l|}{ Mound } \\
\hline Area $\left(m^{2}\right)$ & 3700 & unknown & $2474^{* * *}$ & 225 & 1500 & 306 & $B 2$ & 75 & 225 & $144^{a n+m k}$ & 207 \\
\hline \multicolumn{12}{|l|}{ Estimated } \\
\hline \multirow[t]{2}{*}{ Volume $\left(m^{3}\right)$} & 17000 & unknown & $7886^{* * *}$ & 225 & 4500 & 302 & 100 & $112-150$ & 337 & 132 & 207 \\
\hline & & & A.D. & A.D. & & A.D. & A.D. & & & A.D. & \\
\hline $\begin{array}{l}\text { Age of } \\
\text { Component }\end{array}$ & unknown & $\begin{array}{c}\text { A.D. } \\
B 00-1200\end{array}$ & $\begin{array}{l}1000- \\
1400\end{array}$ & $\begin{array}{l}1200- \\
1400\end{array}$ & unknown & $\begin{array}{l}1400- \\
1600\end{array}$ & $\begin{array}{l}1400- \\
1600\end{array}$ & Ca. A.D. & unknown & $\begin{array}{l}B 00- \\
1200\end{array}$ & unknown \\
\hline \multicolumn{12}{|l|}{ Mound } \\
\hline Structures & & $?$ & $x$ & $x$ & & $?$ & & & $x$ & $x$ & \\
\hline \multicolumn{12}{|l|}{ Mound } \\
\hline Burials & $?$ & $?$ & $?$ & & & & & $x$ & & $x$ & $x$ \\
\hline
\end{tabular}


Table 1. Tabulation of Known or Potential Mound Sites in the Sabine River Valley, Northeast Texas and Northwest Louisiana (continued).

\begin{tabular}{|c|c|c|c|c|c|c|c|c|c|}
\hline & $\begin{array}{r}41 \\
\text { VM7 }\end{array}$ & $\begin{array}{c}11 \\
\text { Vพ35 }\end{array}$ & $\begin{array}{c}\text { I.K. } \\
\text { Counts }\end{array}$ & $\begin{array}{c}11 \\
V M 13\end{array}$ & $\begin{array}{c}41 M 0 \\
7\end{array}$ & $\begin{array}{r}41 \\
\text { Yo9 }\end{array}$ & $\begin{array}{c}\text { 41Yo } \\
11\end{array}$ & $\begin{array}{l}\text { A1VD } \\
55\end{array}$ & $\begin{array}{r}11 \text { W0 } \\
349\end{array}$ \\
\hline \multirow[t]{2}{*}{ Landform } & Af & Up & F) & $g t$ & Up & $U_{p}$ & Up & $\mathbf{F} 1$ & Up \\
\hline & Sabine & $\begin{array}{l}\text { Mill } \\
\text { Creek }\end{array}$ & $\begin{array}{l}\text { Crooked } \\
\text { Creek }\end{array}$ & Sabline & $\begin{array}{l}\text { Caney } \\
\text { Cröek }\end{array}$ & $\begin{array}{l}\text { Litt le } \\
\text { Caney } \\
\text { Creek }\end{array}$ & $\begin{array}{l}\text { Caney } \\
\text { Creek }\end{array}$ & $\begin{array}{l}\text { Honey } \\
\text { Creek }\end{array}$ & $\begin{array}{l}\text { Lake } \\
\text { Fork }\end{array}$ \\
\hline Rank & 1 & 2 & 3 & 1 & 3 & 3 & 4 & 3 & 2 \\
\hline \multicolumn{10}{|l|}{ Distance to } \\
\hline Sabine Riv. & 0.9 & 6 & 19 & 0.8 & 32 & 33 & 23 & 20 & 3.0 \\
\hline $\begin{array}{l}\text { Mo. of } \\
\text { Mounds }\end{array}$ & 6 & 1 & 1 & 3 & 1 & 1 & 2 & 1 & 2 \\
\hline Area $\left(m^{2}\right)$ & unknown & 58 & 225 & unknown & 216 & 144 & 83 & 324 & unknown \\
\hline \multicolumn{9}{|l|}{ Est imated } & unk nown \\
\hline $\begin{array}{l}\text { Age of } \\
\text { Component }\end{array}$ & unknown & unknown & unknown & $\begin{array}{l}\text { A.D. } \\
1000= \\
1400\end{array}$ & $\begin{array}{l}1.0 \\
1000= \\
1400\end{array}$ & $\begin{array}{c}\text { A.0. } \\
1000- \\
1400\end{array}$ & unk nown & $\begin{array}{c}\text { A.D. } \\
1200- \\
1500\end{array}$ & $\begin{array}{l}\text { A.D. } \\
1000= \\
1400\end{array}$ \\
\hline \multicolumn{10}{|l|}{ Mound } \\
\hline Structures & $x$ & & $?$ & & $?$ & $x$ & $?$ & $x$ & $x$ \\
\hline \multicolumn{10}{|l|}{ Mound } \\
\hline
\end{tabular}

"Qt-Quaternary alluvlal terrace: Flafloodplain: Up=Upland: Ml=hatural levee: Af-alluvlal fan

"Based only on Mound 1. The other mound has not been conclusively identlfled as artificial in construction.

a.e.

Based only on Mounds A-C. The dimenstans of the other mounds are not known.

Based on ly on Mound $A$. 
(Figure 2). Significant pothunting has occurred at $41 U R 30$ in the last five years, and a large Early Caddoan cemetery has been destroyed through this work.

One of the mounds at the Hudnall-Pirtle site (41RK4), then known as the BivinsFlanagan mound, was investigated about 1960 by Buddy C. Jones (see Davis et al. 1971), now of the Florida Bureau of Historical Research. None of that work was ever published, and any materials recovered during Jones' work is apparently now for sale along with the rest of his large collection accumulated in the 1950s-1960s. More recent investigations at the site have been conducted by the Texas Historical Commission with the sponsorship of The Archaeological Conservancy (Bruseth 1991).

In the 1960s the University of Texas and Southem Methodist University conducted testing and excavation projects at several mound sites at Toledo Bend Reservoir, most notably at the Lafitte (41SY15) [Scurlock 1964] and the Coral Snake Mound (16SA48) sites. The latter is an Early Ceramic or Woodland Period burial mound (McClurkan et al. 1966, 1980; Jensen 1968a; Story 1990).

Three mound sites, 41RA31, 41RA38, and 41VN35, were recorded during a 19701971 Texas Historical Commission survey of proposed Carl Estes Lake in the Upper Sabine River basin (Malone 1972), and 41WD7 and 41WD9, mound sites initially recorded by A.T. Jackson in 1930 (Wilson and Jackson 1930), were relocated by Southern Methodist University during the Lake Fork Reservoir project (see Skiles and Perttula 1989). Limited test excavations were conducted in 1978 at one of the sites, J.O. McCreight (41WD9), on Little Caney Creek in the Upper Sabine River Basin (see Figure 2). Southern Methodist University also conducted minimal excavations at the Jamestown (41SM54) and Cox (41WD349) mound sites in the late 1970s, but the notes, artifacts, and photographs from that work have been lost or misplaced.

In the early 1980s, the Brittain (41SY42) and Beauchamp Creek (41SY46) mound sites were reported in or adjacent to the U.S. Forest Service's Sabine National Forest in Shelby County, Texas (see Figure 2). A small test hole was excavated by John Ippolito 


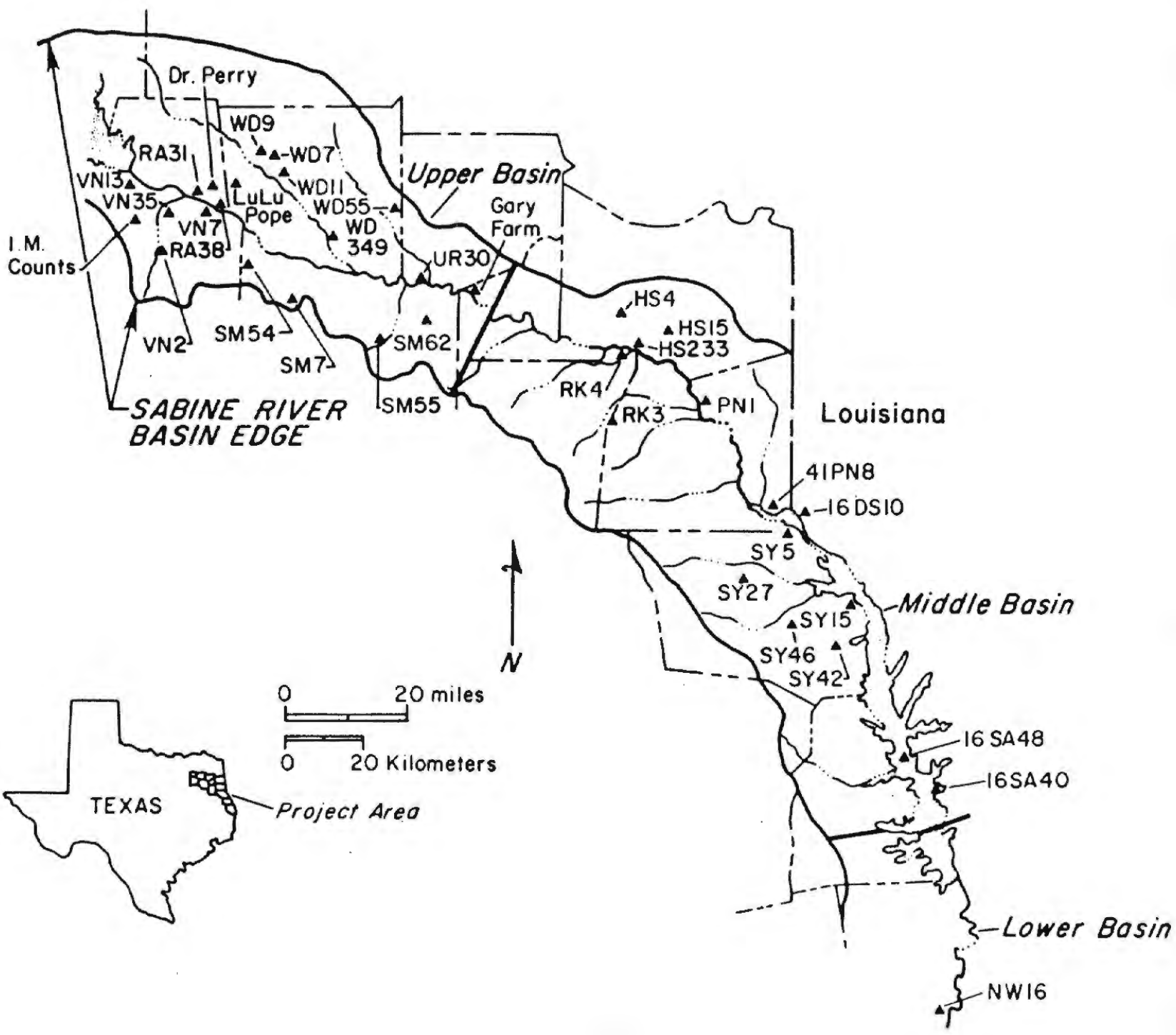

Figure 2. The Distribution of known and potential mound sites in the Sabine River Valley. 
(1988), Forest Archeologist, in one of the reported mounds at the Beauchamp Creek site, but nothing of significance was apparently recovered from this work other than to demonstrate that it was of artificial construction.

Almost all the Sabine River Basin mound sites have been potted or vandalized at one time or another from the late nineteenth through the twentieth century. However, few have been as extensively disturbed by looters as have Caddoan cemetery sites throughout the region (Perttula 1989b), with the notable exception of the above-mentioned looting at the Boxed Springs (41UR30) mound site where a cemetery containing more than 125 individuals was found adjacent to one of the mounds.

Consequently, many of the mounds themselves still possess some degree of overall contextual integrity, and in cases where off-mound habitation areas exist, they have not yet been seriously damaged by looting activities. Apparently, with the exception of the Boxed Springs cemetery, cemetery areas in off-mound habitation settings are relatively uncommon on Sabine River Valley mound sites.

\section{Regional Spatial Patterns}

The Sabine River Basin is divided into Upper, Middle, and Lower basins utilizing physiographic, geomorphological, and geological criteria (e.g., Kier et al. 1977). The Upper Basin, part of the East Texas Embayment, includes the area from the headwaters of the Sabine River to the western edge of the Sabine Uplift, while the Middle Basin is entirely within the area effected by the Sabine Uplift. The Lower Basin is that part of the Sabine River Valley below the Sabine Uplift and extending to the Gulf of Mexico (see Gibson 1978) [Figure 3].

With the exception of one possible mound site in Newton County, Texas, in the Lower Basin, the Goode Newton site (41NW16), all the other known or possible mounds recorded in the Sabine River Valley are located in the Upper and Middle Basins (Table 2). In the Upper Sabine Basin, mound sites are concentrated on the Sabine River, Lake Fork 


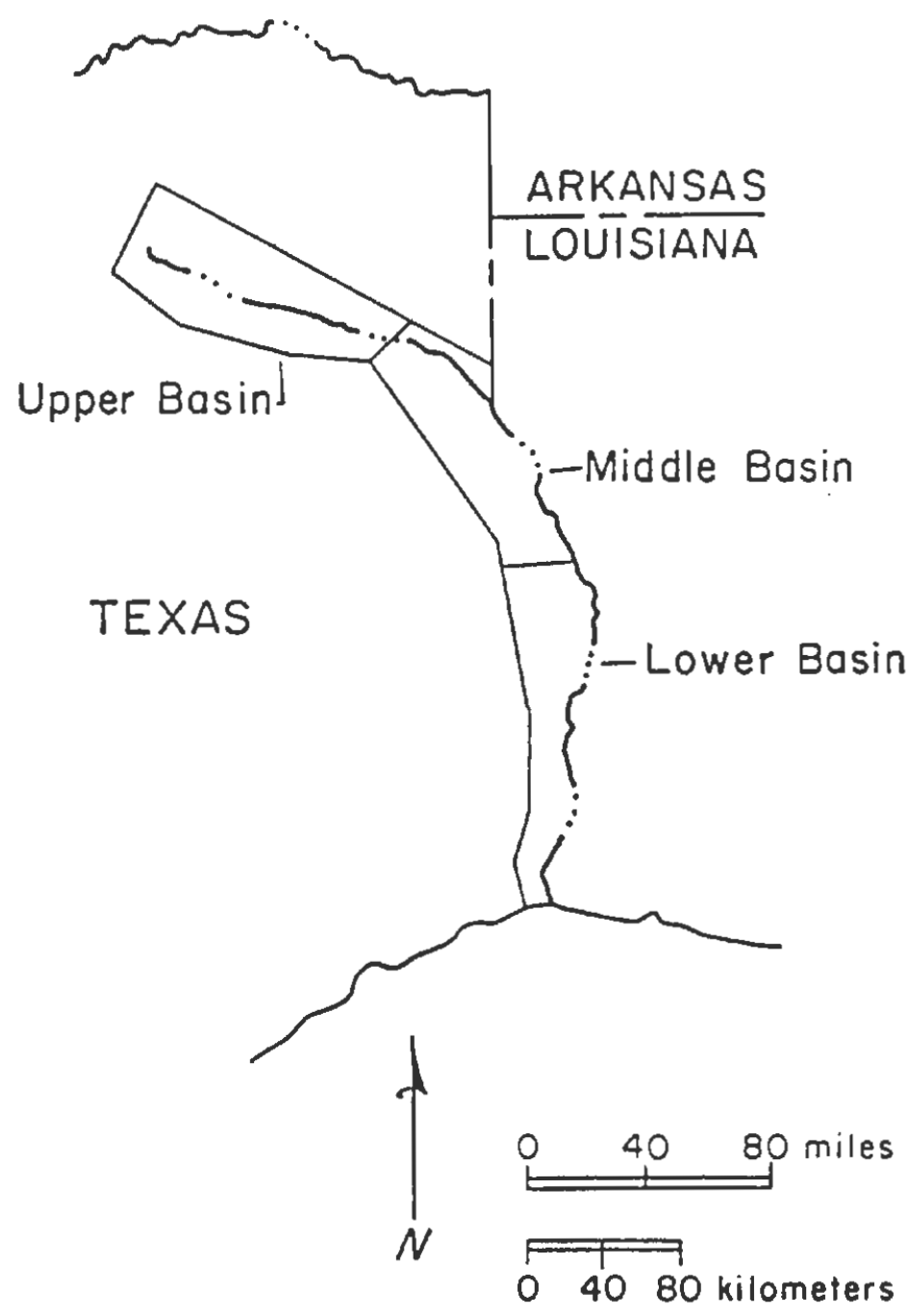

Figure 3. The intra-basin divisions of the Sabine River Basin, Northeast Texas and Northwest Louisiana. 

and selected Parameters.

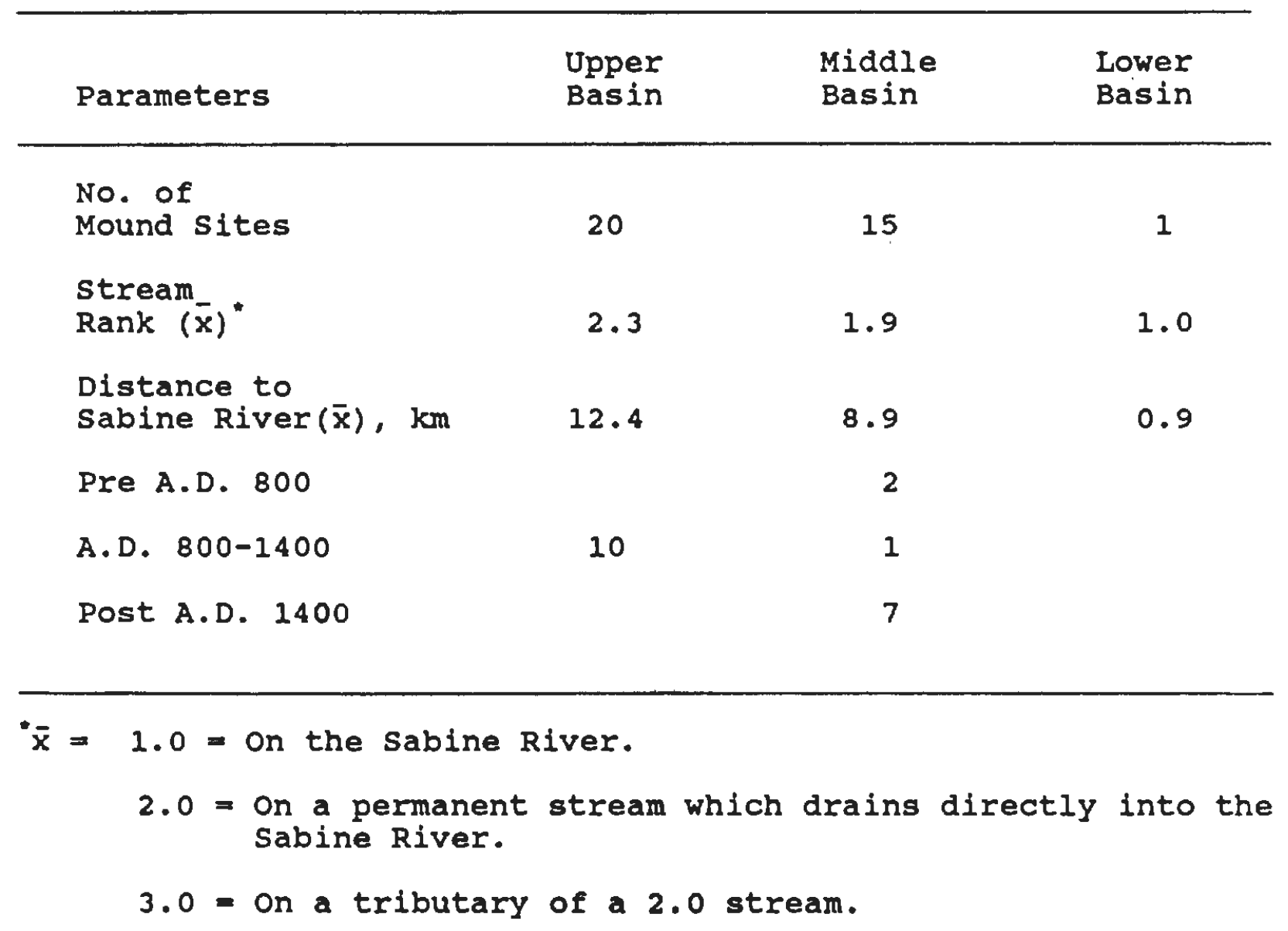


Creek and tributaries, and on north-flowing tributaries of the Sabine River such as Mill Creek, Crooked Creek, and Village Creek (Figure 4). Mound sites are particularly common in the Post Oak Savannah ecotone, and one of the sites thought to have been a premier or key mound site in the Upper Basin (see below), the Jamestown site (41SM54), is situated along the probable edge of the Post Oak Savannah and the Pineywoods (see Figure 4). No mound sites in the Upper Basin are situated in the Blackland Prairie, and with the exception of the Lee Joyner Farm (41VN13), they are at least 10 to 20 kilometers east of the tall grass prairie habitat (see Figure 4).

Multiple mound sites in the Upper Sabine Basin include the Boxed Spring (41UR30), Cox (41WD349), Jamestown (41SM54), Colony Church (41RA31), M.J. Speers (41VN7), and Lee Joyner (41VN13) sites. With the exception of the latter two sites, where evidence of mound-building activities is still circumstantial and the number of deliberately constructed mounds has not been clearly established, the other multiple mound sites contain between two and seven mounds per site (see Table 1). Both the Jamestown (41SM54) and Boxed Springs (41UR30) sites contain evidence for extensive settlements associated with the mounds, and thus were clearly not vacant Caddoan community centers (see Story 1990:341).

The key multiple mound sites in the Upper Sabine Basin are the Jamestown (41SM54) and Boxed Springs (41UR30) sites. This is suggested based on the number, size, internal arrangement and spacing, and presumed character of the mounds at each of the sites, as well as the extent of the associated settlements $(+15$ acres) [Perttula 1989a:67-70, 78-80). The regular spacing of mound centers along the major streams and tributaries in the Upper Sabine Basin also hints at the existence of locally integrated and culturally associated Early and Middle Caddoan Period (ca. A.D. 800-1400) communities or networks (see below) which may have been part larger social and culturally related regional community or population group that extended into the Middle Sabine Basin. 


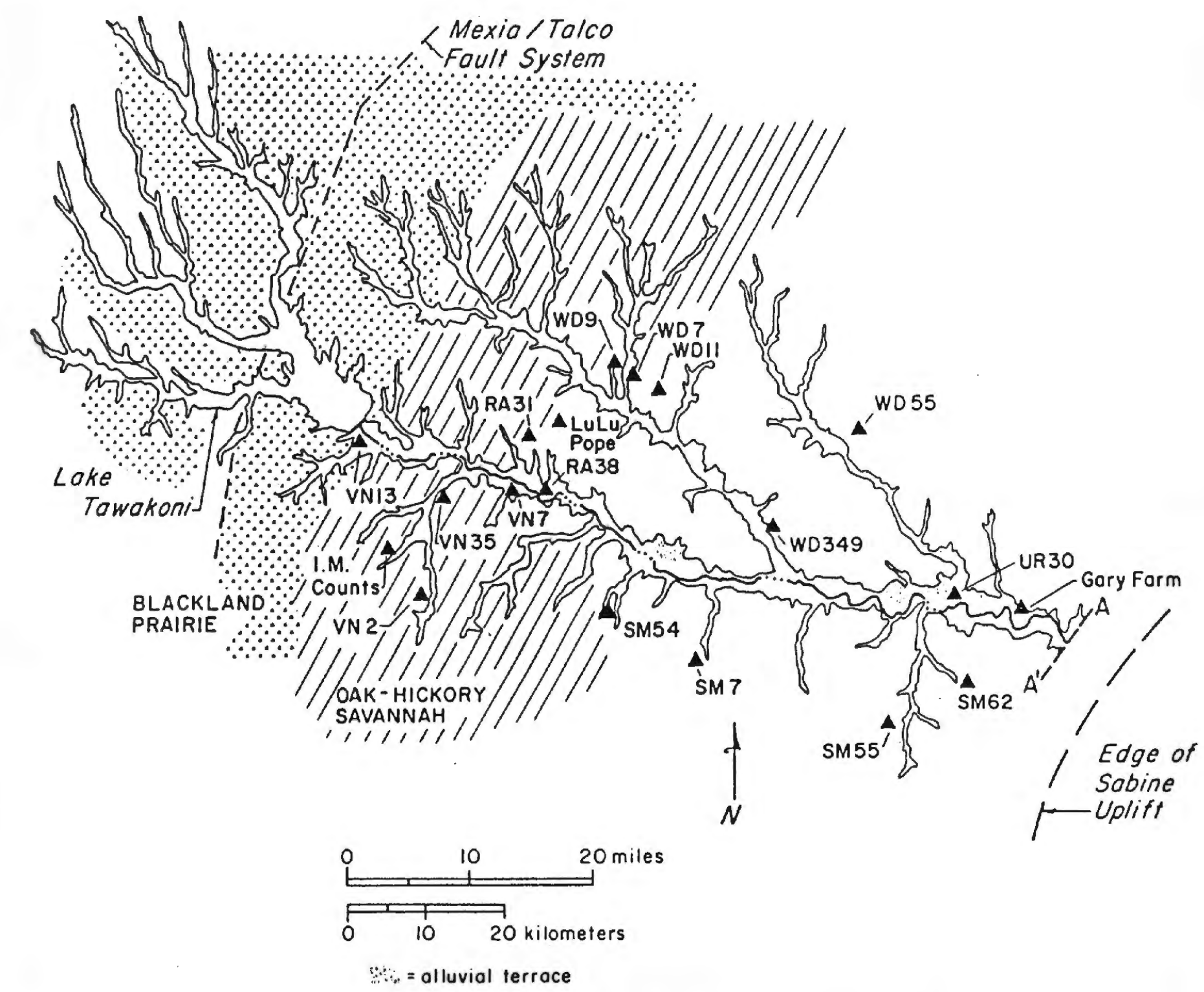

Figure 4. The location of mound sites in the Upper Sabine River Basin. 
Mound sites in the Middle Sabine Basin (Figure 5) are distributed in a spatial pattern quite similar to that noted in the Upper Basin. That is, mound sites are located on the Sabine River floodplain or alluvial terraces, but they are more common on permanent streams which are tributaries to the Sabine River, such as Hatley Creek, Potter's Creek, Martin Creek, and Flat Fork Creek (see Table 2). All mound sites in the Middle Sabine Basin are situated in the Pineywoods.

Multiple mound sites in the Middle Sabine Basin include the Hudnall-Pirtle (41RK4), Lane Mitchell (41HS4), 41HS233, Lafitte (41SY15), and possibly the Gus Jones (41HS15) sites (see Table 1). On the basis of the ceramic assemblage and calibrated radiocarbon dates of A.D. $1158+/-70$ (Beta-43539) and A.D. 1174 +/- 70 (Beta-43540), the Hudnall-Pirtle mound site was apparently occupied during the Early Caddoan Period (Bruseth 1991), but all the others were probably constructed and utilized during some portion of the Late Caddoan Period (ca. A.D. 1400-1600) [see Table 1].

Few other mound sites in the Middle Sabine Basin can be positively identified as having an Early or Middle Caddoan Period occupation, and thus the Hudnall-Pirtle mound center is clearly an isolated premier or key mound group in this part of the basin. Indeed, the size of the site and its associated settlement ( +60 acres), the number of flat-topped platform mounds and conical mounds (three and five, respectively), and the likely presence of a plaza area (Bruseth 1991), all indicate that the Hudnall-Pirtle site is the most prominent Caddoan mound center in the Sabine River Basin of Northeast Texas and Northwest Louisiana. Story (1990:325) suggests that the George C. Davis mound site on the Neches River was colonized from the area of the Hudnall-Pirtle site in the Middle Sabine Basin. The Hudnall-Pirtle site is situated in the Sabine River floodplain on a prominent alluvial terrace, located in the approximate middle of the $\mathbf{3 0 0}$ kilometer stretch of the Sabine River Valley that was occupied by mound-building Caddoan groups (see Figure 2).

Only a single possible Caddoan mound site is known in the Lower Sabine River basin (Figure 6). The Goode Newton site (41NW16) is located on an alluvial knoll in the 


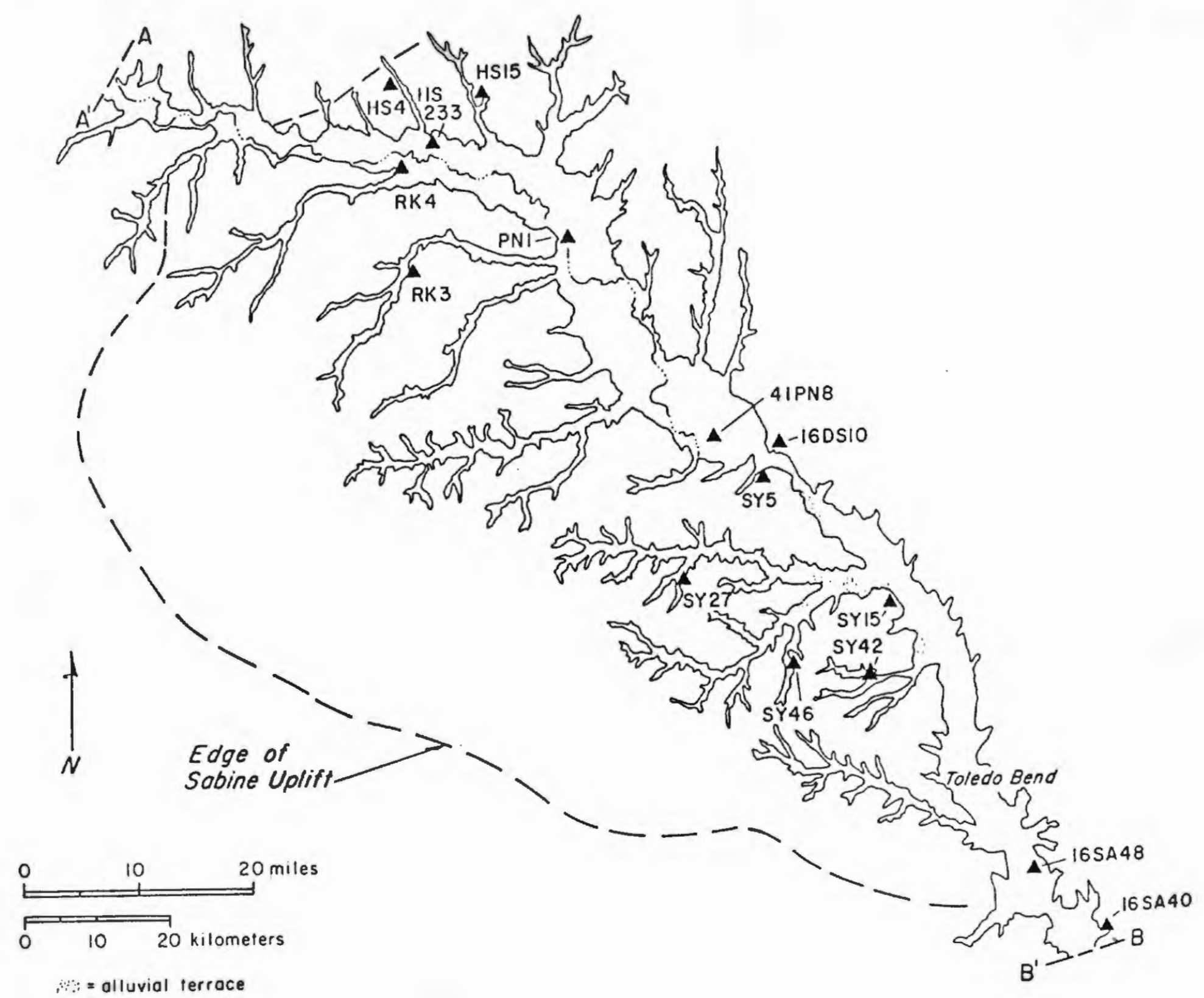

Figure 5. The location of mound sites in the Middle Sabine River Basin. 


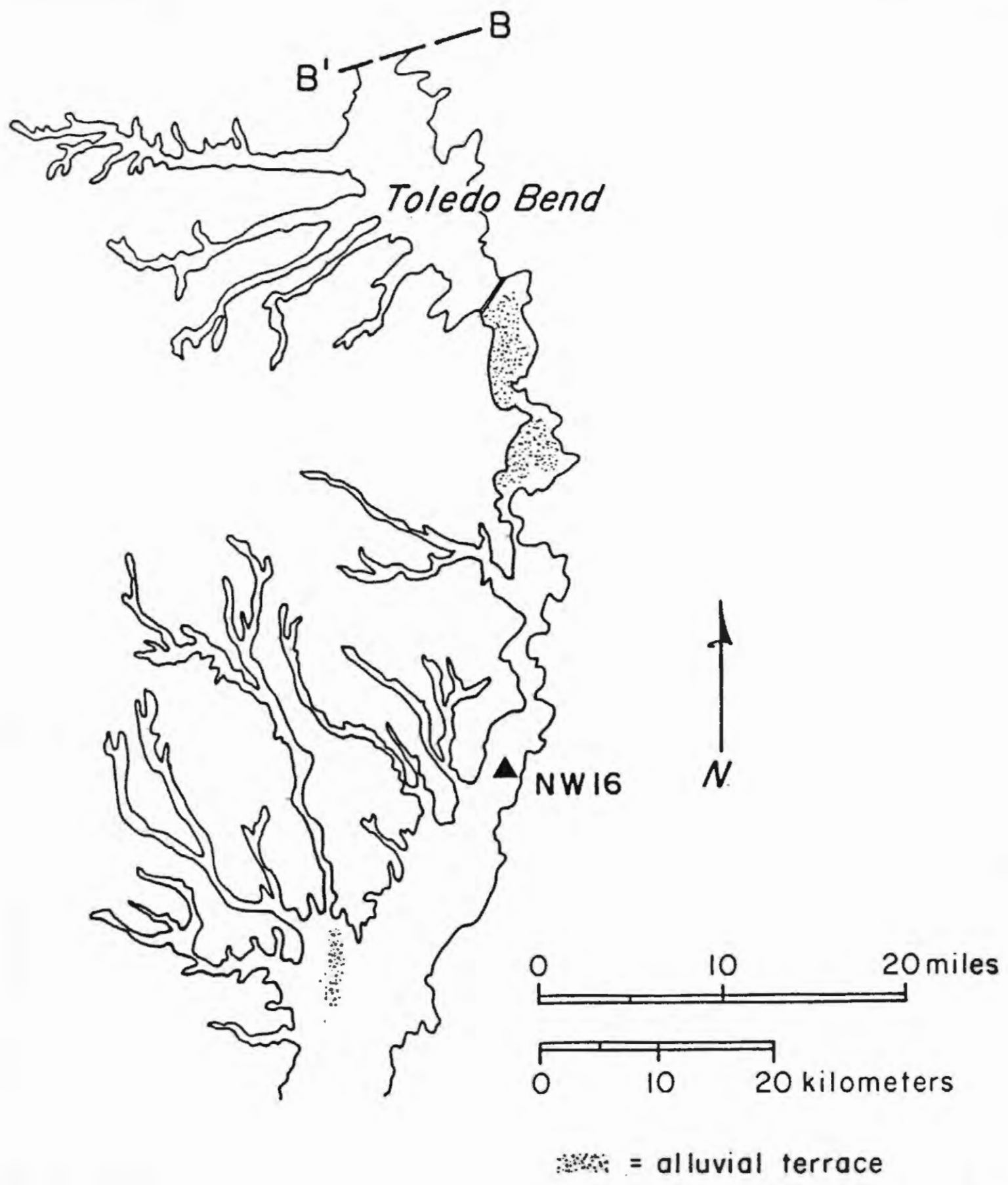

Figure 6. The location of mound sites in the Lower Sabine River Basin. 
Sabine River floodplain, more than 60 kilometers south of the next nearest mound, the Anthony site (16SA7 or X16SA40). Neither site has been professionally investigated, and the available information about them is rather limited (Perttula 1989a:47, 56-57; Story 1990:279).

\section{Social and Temporal Considerations}

It is presumed that the use of mounds by Caddoan peoples represents deliberately patterned cultural behavior expressing social, religious, and symbolic principles shared by related groups and communities (see Rogers 1989; Kay et al. 1989). For instance, Sabo and Early (1988:98) suggest that:

social or ceremonial activity at these individual centers [Caddoan mound sites in the Arkansas River and tributary valleys] promoted the solidarity of the local communities responsible for the construction and maintenance of these centers, in addition to providing contexts for the expression of important aspects of social structure such as systems of ranking (e.g., Brown 1971; Rogers 1982, 1983). We may suggest also that the Network of mound centers... promoted socially integrative activity on a larger level than the local corporate group; that is, solidifying geographically separated, small corporate groups into a single, regional community [brackets added; emphasis in the original].

Possible premier or key mound centers and subsidiary mound centers are identified in the Upper and Middle Sabine Basin that are suggestive of the existence of a hierarchical social, political, and religious structure behind the temporal and spatial patterning noted for mound groups in both Early/Middle and Late Caddoan Period occupations (Figure 7). In the Early Ceramic Period (ca. 200 B.C.-A.D. 800), only a single mound site is known in 


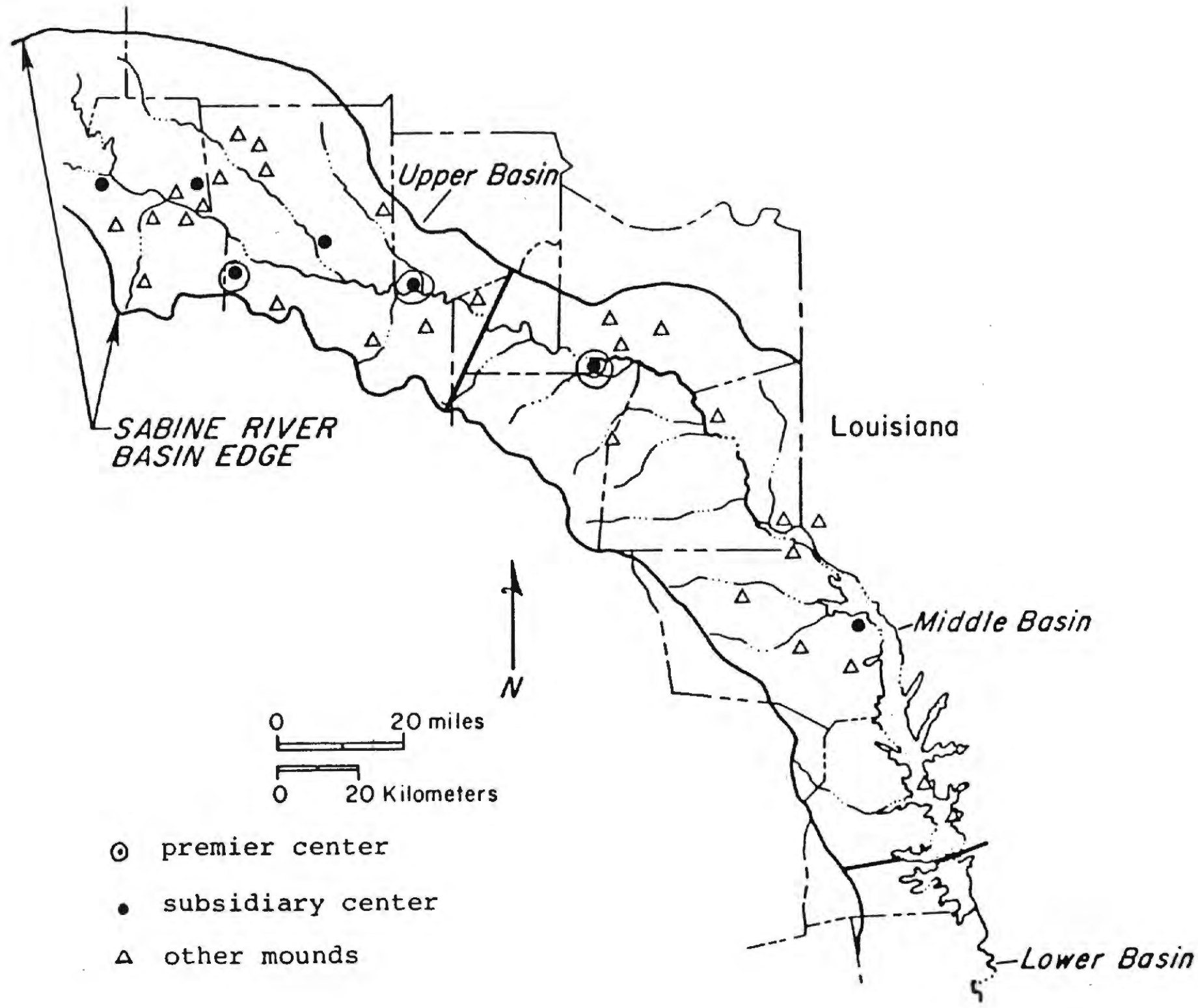

Figure 7. The distribution of possible premier and subsidiary mound sites. 
the Sabine River Basin, the Coral Snake burial mound site (16SA48) [see Jensen 1968a, 1968b; Story 1990:282-289 for further details].

The identifications of premier or key mound centers is based on a number of variables, including: mound sizes, internal mound arrangement and spacing, the existence of plazas, and inferred mound functions (i.e., as mantles over burials, as bases for specialized buildings such as charnel houses or temples, or to mantle sub-surface features). The large and internally complex mound centers at the Jamestown, Boxed Springs, and Hudnall-Pirtle sites are considered the premier centers in the Sabine River Valley. They are Early to Middle Caddoan Period mound centers with four to eight mounds each (Figure 8).

Possible contemporaneous Early to Middle Caddoan Period mound centers that are considered subsidiary or secondary nodes in such a hypothetical hierarchical system are the Cox and Colony Church (41RA31) sites, and possibly the Lee Joyner or Seaton Bros. (41RA38) sites (see Figure 7). Subsidiary mound centers are identified as those sites containing multiple mounds, but lacking the complex internal arrangements and spacing of mounds and plaza noted for the premier or key mound centers, nor do they have the variety of mound types identified or postulated for the Jamestown, Boxed Springs, or Hudnall-Pirtle sites (see Table 1).

Late Caddoan Period mound sites are common in the Middle Sabine River Basin, particularly in southwestern Harrison County and Shelby County, Texas (see Figure 8). Mound types represented include possible substructural mounds, and a possible burial mound at the Brittain site (41SY42). Since they have multiple mounds, the Lafitte site (41SY15), and possibly Lane Mitchell (41HS4), may represent one of the civic-ceremonial foci of the local Late Caddoan groups living in this area of the Sabine River Basin. The mounds are in the vicinity of numerous Late Caddoan Period habitation sites along the Sabine River and eastward flowing tributaries. These Late Caddoan Period settlements may be related to the Titus phase Cypress Cluster (cf. Thurmond 1985, 1990; Perttula 1992, 


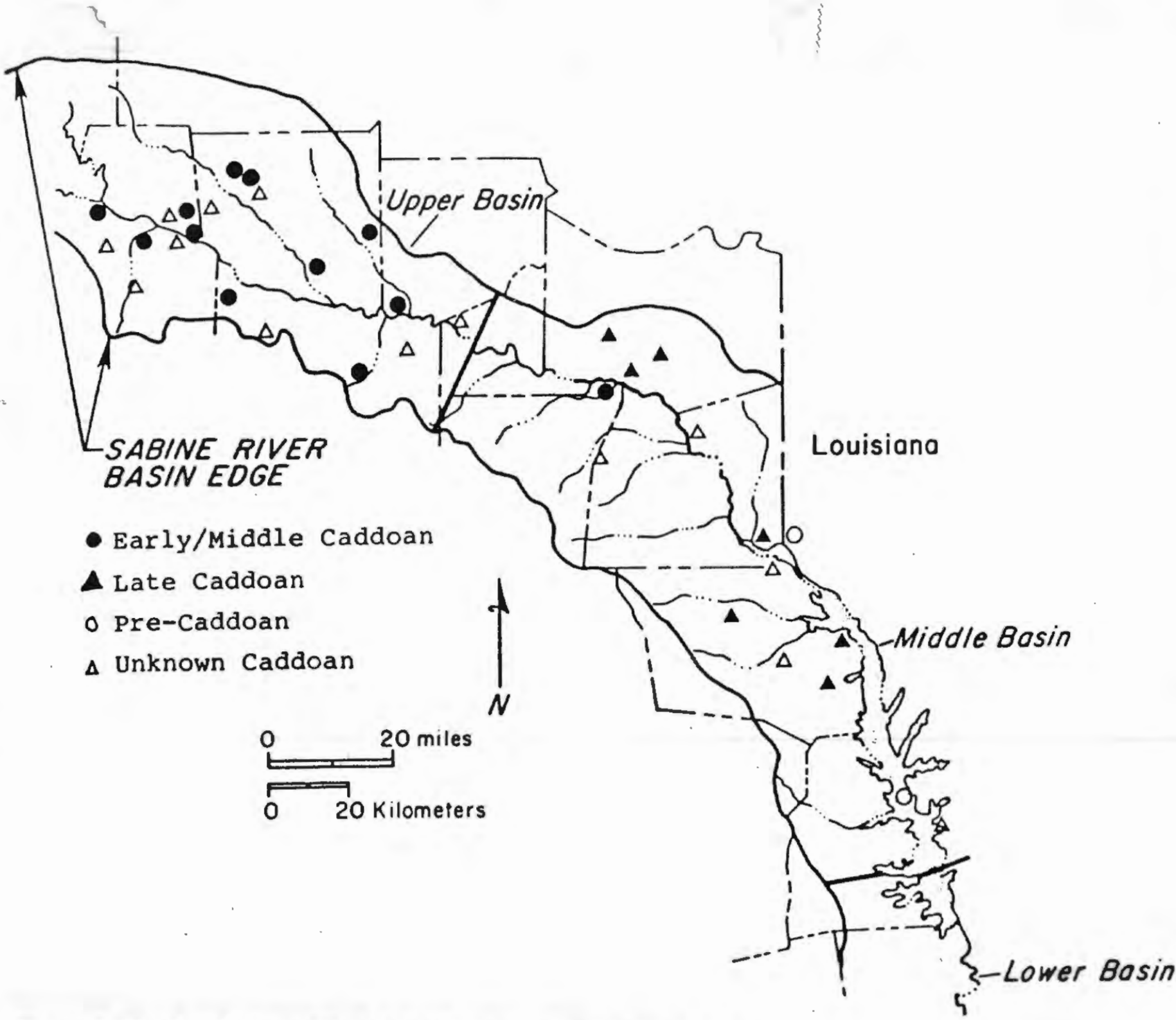

Figure 8. The distribution of Early/Middle and Late Caddoan Period mound sites. 
1993a), but the cultural-taxonomic systematics in this part of Northeast Texas require considerable refinement and redefinition (Story 1990:167-168 and Table 43).

No Late Caddoan Period mound groups are known in the Upper Sabine River basin, although Perttula et al. (1986:57) suggest on the basis of limited ceramic evidence that the A.N. Vickery site (41WD11) may have been occupied during this period. The lack of mounds in this part of the basin does not mean that the area was unoccupied ca. A.D. 1400-1600, because the regional density of Late Caddoan habitation sites is much more substantial in parts of the Lake Fork and Big Sandy Creek drainages within the basin than was the Early and Middle Caddoan Period settlement (e.g., Bruseth and Perttula 1981; Perttula and Gilmore 1988; Perttula et al. 1986, 1993; Thurmond 1985, 1990).

Figure 9 presents a hypothetical picture of the extent and distribution of possible Early/Middle Caddoan and Late Caddoan Period local networks of socially integrated groups in the Upper and Middle Sabine River Basins. It is based on the identification of basin-wide premier mound centers, which are assumed to be the nodes of a local community, and the regular geographic spacing between the premier mound centers and other possible contemporaneous subsidiary mound sites (Figure 10 and 11). The pattern of mound spacing is consistent across at least the upper 120 kilometer stretch of the Sabine River Valley, irrespective of the local geography, topography, or stream drainage patterns.

During the Early/Middle Caddoan periods, the premier centers within the valley are ca. 50 kilometers apart, and the subsidiary centers are ca. 25 kilometers from the premier centers. Based on these distances, and clusters of settlements, the local networks of contemporaneous Caddoan mound-building groups in the Sabine River Basin may be estimated to be on the order of between ca. 1000 to 2000 square kilometers (see Figure 9). The one likely Late Caddoan Period local network of mounds and settlements which can be identified using available information covers ca. 1000 square kilometers, with subsidiary mound sites within 15 to 30 kilometers of the suspected Key center, the Lafitte site (41SY15) [see Figure 11]. 


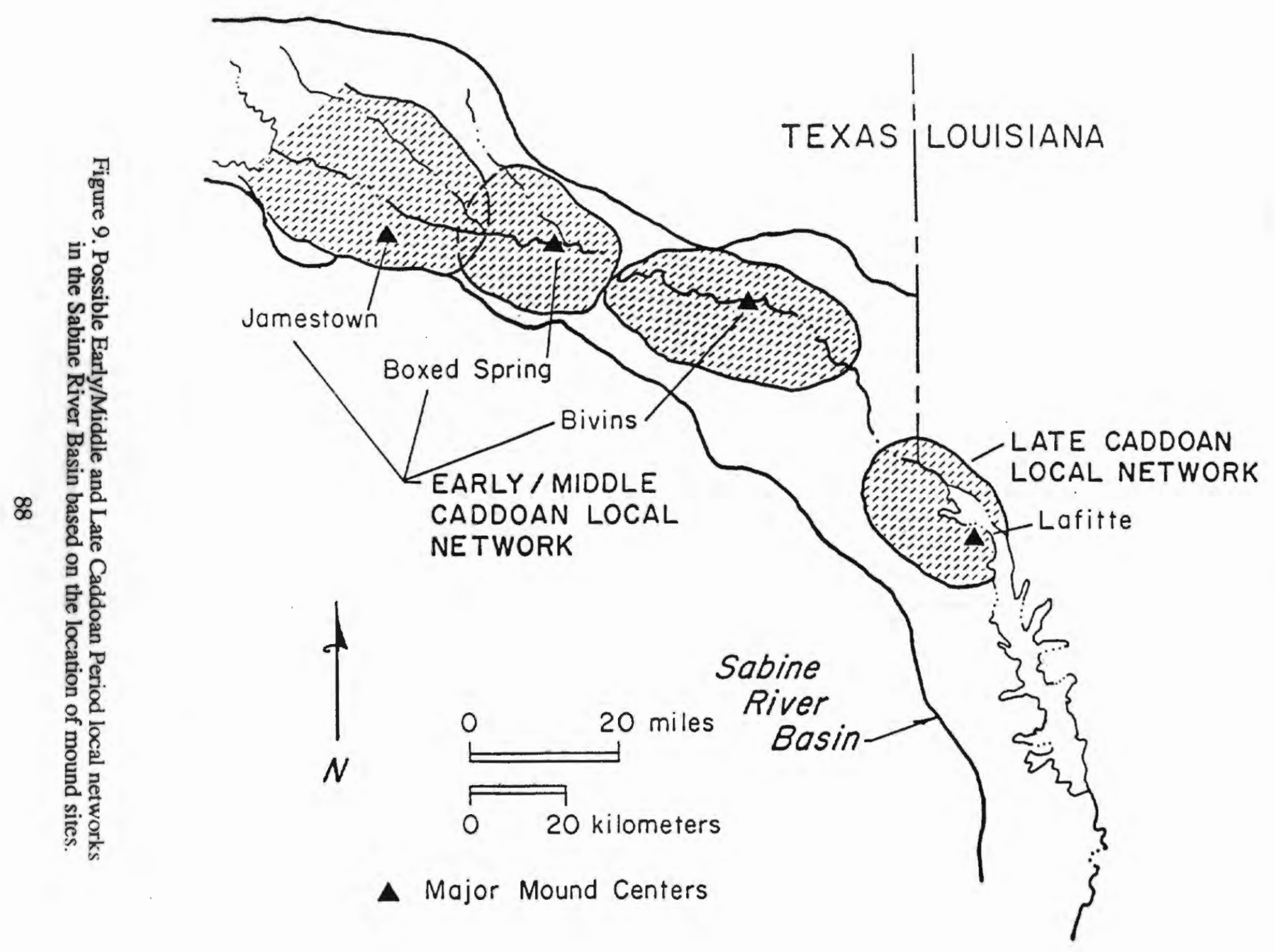



a. Cox (WD349)
b. Colony Church (RA31)
c. Lee Joyner (VN13)
d. Shuart (SM7)
e. B.G. Price (WD7)
f. Fruitvale (VN35)

g. McKenzie (WD55)

h. John T. Cox (VN2)

i. Bryan Hardy (SM55)

j. 41 SM62

k. Prairie Creek

1. Grand Bluff (PN1)

m. Millsey Williamson (RK3)
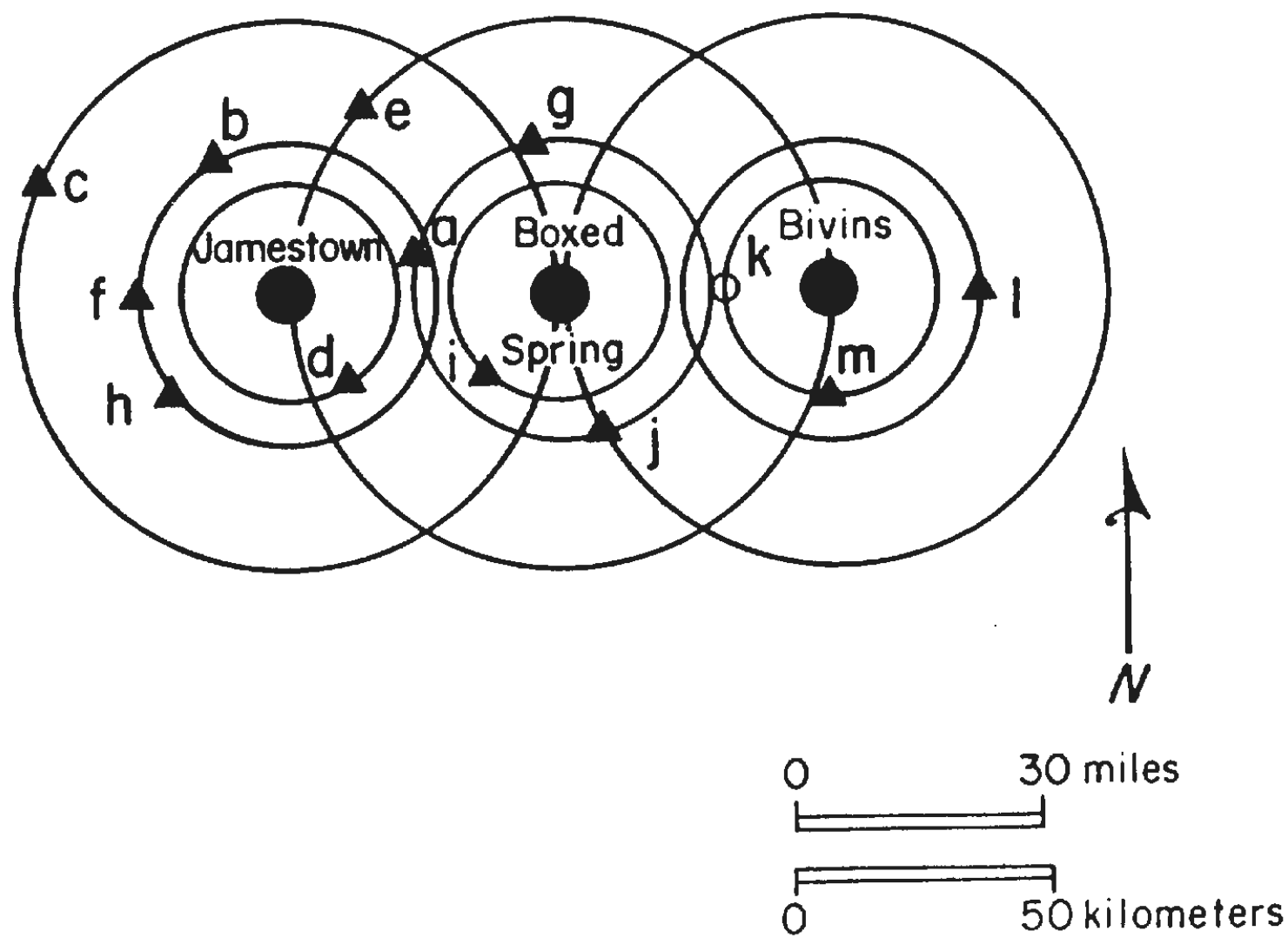

Figure 10. Caddoan mound site distributions in the Sabine River Basin compared to three potentially Key central mound groups. 


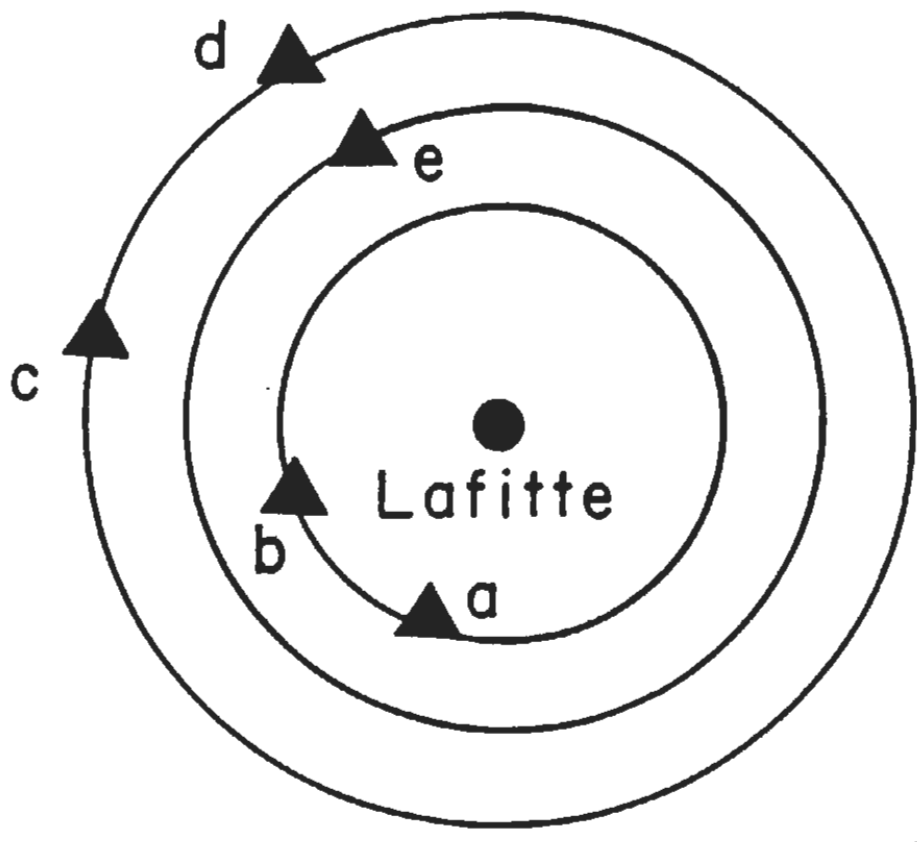

a. Brittain (SY42)

b. Beauchamp Creek (SY46)

c. Chicken Bayou (SY27)

d. Clear Lake (PN8)

e. T.A. King (SY5)

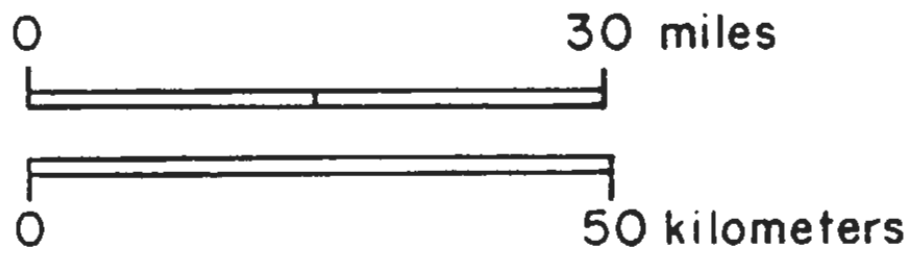

Figure 11. Possible Late Caddoan mound site distributions in the Middle Sabine River Basin compared to one potentially Key central mound group. 
Trends in mound construction and use in the Sabine River Basin are similar to those outlined by Thurmond (1990:234-235) for the Cypress Creek Basin (immediately to the north of the Sabine River Basin) of Northeast Texas and Northwest Louisiana. In the Cypress Creek Basin there is a general decrease through time in the size and complexity of mound centers, and only in the Red River floodplain area of Northwest Louisiana could it be demonstrated that mound building activities continued after ca. A.D. 1500-1600 (cf. Webb 1959).

In the period between ca. A.D. 800-1200 in the Cypress Creek Basin, mound groups were classified by Thurmond (1990:234) into large, multi-mound centers and small single-mound components. Thurmond (1990:234) states that: "It seems quite possible that a hierarchical system of centers is represented, with each succeeding level serving a broader area, and the whole integrated into a regional network of interaction and redistribution."

Such a hierarchical system of mound centers is also postulated in the Sabine River Basin between ca. A.D. 800-1200 (or as late as A.D. 1400), with the Jamestown, Boxed Springs, and Hudnall-Pirtle sites representing the apex or top level of the hierarchical system. The regional network may have included groups in both the Upper and Middle Sabine River Basins, based on the spacing considerations discussed above (see Figure 9), but was also integrated as well into a broader system of interaction and redistribution that probably extended throughout larger portions of Northeast Texas and Northwest Louisiana. It is interesting to note, therefore, that the spacing between the major Early Caddoan Period mound centers of Crenshaw, Gahagan, and Mounds Plantation on the Red River in Northwestern Louisiana and Southwestern Arkansas is about $80 \mathrm{~km}$ (Webb and McKinney 1975:122), and that the Hudnall-Pirtle site, the premier Early Caddoan Period mound center in the Sabine River Basin, is about the same distance from both Mounds Plantation and Gahagan. 
The term local network employed herein is analogous to the affiliated group defined by Story and Creel (1982:32 and Figure 8) for the Neches River Late Caddoan Period archaeological record. According to Story and Creel (1982), the affiliated group represents the archaeological concept of a number of constituent groups who shared a similar socio-political organization, had similar intergroup interaction and settlement patterns, and were integrated in a hierarchical structure by the temple-residence complex center. This center contained an earthen mound where the paramount leader of the affiliated group resided. The constituent group would consist of the lesser centers (without mounds), domiciles, cemeteries, farmsteads, hamlets, and villages that are socio-politically unified into the affiliated group. With the exception that the subsidiary centers in the Sabine River Basin during the Early, Middle, and Late Caddoan Periods have at least one earthen mound, they may be considered to be representative of a level of socio-political integration generally compatible with Story and Creel's (1982) model of a constituent group lesser center.

The patterned arrangement of mounds within a site, consistent means or methods of mound construction, the recurrent use of a restricted space for mound construction, structure dismantling, as well as other ritualized activities in Caddoan mound centers, highlight the contextual importance of mound use in Caddoan culture (e.g., Sabo and Early 1988:99; Story 1990:339-342; Perttula 1992). One particularly intriguing aspect of the use and patterned arrangement of mounds in the Southeastern United States is the correlation of mounds with celestial orientations, and with a consistent unit of spacing referred to as the Toltec module (Sherrod and Rolingson 1987).

Some of the major Caddoan mound sites studied by Sherrod and Rolingson (1987:Table 16) exhibit celestial alignments, principally the winter and summer solstice sunrises. In the Sabine River Valley, the only multiple mound centers with fairly accurate maps of mound placement and spacing are the Jamestown and Hudnall-Pirtle sites. At the Jamestown site, both the summer solstice (the year's midpoint) and winter solstice 
(beginning of the annual cycle or year, and the time of the longest night) alignments are apparent using the large Mound $\mathrm{A}$ as the primary point (Figure 12). There is also a stellar alignment with Vega, "one of the brightest stars seen from the northern hemisphere" (Sherrod and Rolingson 1987:29). The Toltec module standard of measure, 47.5 meters, correlates well with the spacing of only three of the other six mounds at the Jamestown site (see Figure 12).

Other evidence of a complex hierarchical structure beyond the number, size, plan, and complexity of mound centers is obtained by examining mortuary behavior in mound contexts (see Thurmond 1990:235). The recovery of burials with elaborate funerary offerings and exotic goods as grave associations with paramount individuals, typically adult males, in mound contexts has been argued by Caddoan archaeologists (see Brown 1971; Rogers 1982; Sabo and Early 1988) to represent high-status burials and the existence of a ranked class structure. With the exception of the centrally located sub-mound burial pit from one mound at the Boxed Springs site (see Perttula 1989a:78-80; Story 1990), which because of its position and burial accompaniments has been interpreted to be a high status burial, it is not possible at present to conclusively demonstrate either that the premier centers in the Sabine River Basin all contain evidence of high status burials, or that the sociopolitical interpretations embedded in the hierarchical classification of mounds are realistic. Attempts to demonstrate that the temporal, spatial, and functional differences in mound centers within the Sabine River Basin are the result of sociopolitical distinctions will require a more comprehensive investigation of these mound sites before these proposed archaeological units can be fully related to regionally and locally meaningful cultural variability (e.g., Johnson 1987). 


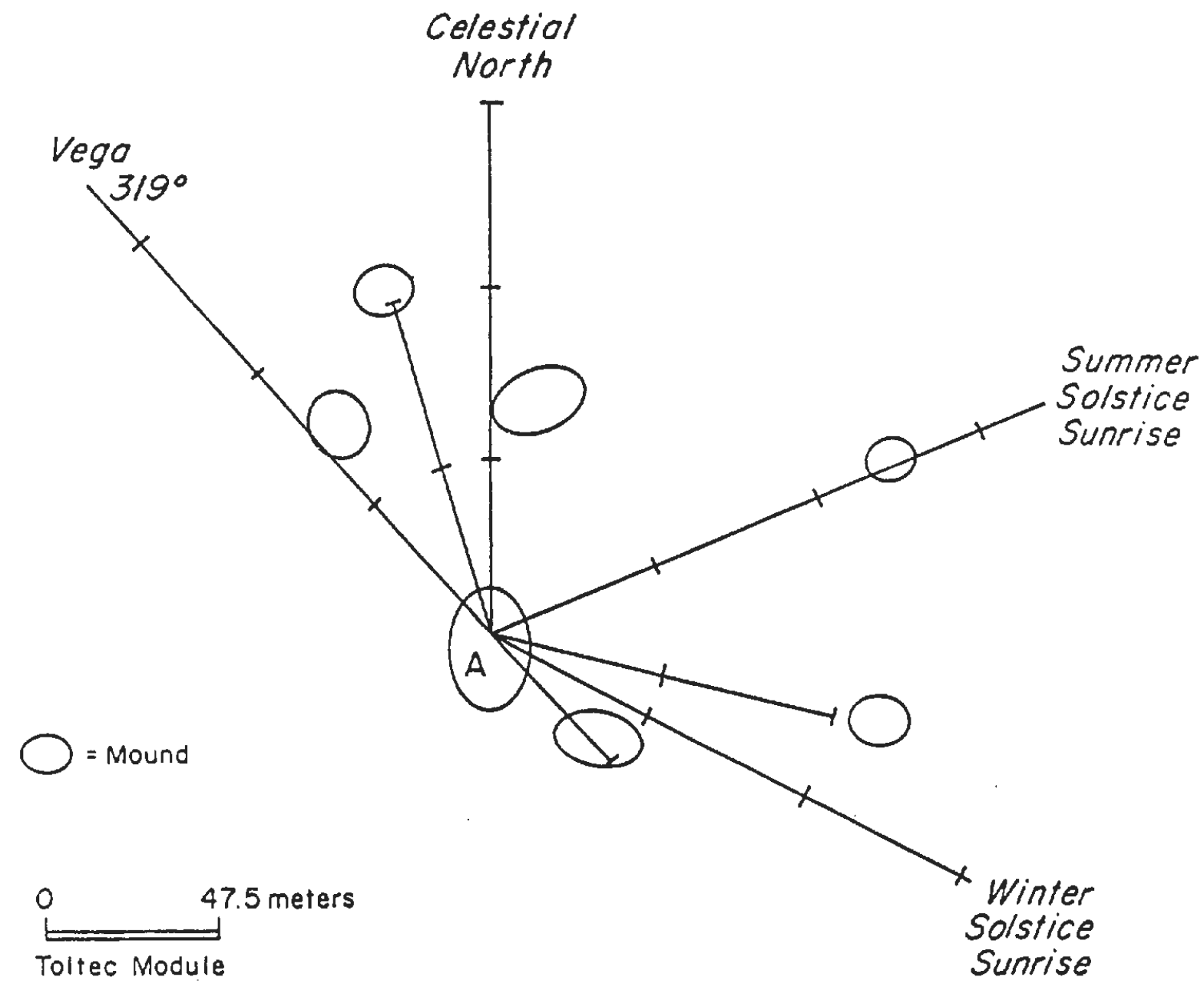

Figure 12. Celestial and Stellar Alignments and the Toltec Module Standard of Measure at the Jamestown Site (41SM54). 


\section{Conclusions}

A substantial body of information exists about prehistoric mound sites in the Sabine River Valley of Northeast Texas and Northwest Louisiana. Previous sections of this paper summarized the more significant aspects of patterning in the mound sites from the valley, including Caddoan Period intra-regional spatial distributions, social and temporal considerations, and celestial and stellar alignments. Three key multiple mound centers are identified for the Early/Middle Caddoan Period occupation of the basin, namely Jamestown (41SM54), Boxed Springs (41UR30), and Hudnall-Pirtle (41RK4), while the Lafitte site (41SY15) is provisionally identified as the key local Late Caddoan Period mound center.

It is important to reiterate that the majority of the mound sites known and/or investigated in the Sabine River valley appear to be generally intact. Although it is the case that these Caddoan mound sites have been cleared and plowed over the last 100 years or so, and have been the scene of occasional vandalism and looting activities, they have not as a group been subjected to the intensive and systematic disturbances caused by looting on Caddoan cemetery sites that contain certain artifacts which garner a high price on the antiquities market in Texas, Arkansas, and other states (e.g., Early 1989; Perttula 1989b). The reasons behind why Caddoan mound sites are not extensively disturbed have not been thoroughly studied, but one primary reason may be the pothunter's perception that these mound sites generally do not contain the types of easily worked archaeological deposits common at aboriginal cemeteries, nor do they necessarily contain the number and variety of contexts from which high-priced lootable goods can be quickly obtained.

Since Caddoan mound sites as a group appear to retain a measure of integrity not typically held by other types of Caddoan sites in Northeast Texas and Northwest Louisiana, it is critical that measures be implemented by State and Federal agencies, the professional archaeological community, avocational archaeologists, and interested landowners, to insure the preservation and protection of as many of these important sites as possible. A site protection and preservation plan for Caddoan mounds in the Sabine River 
Valley, and indeed for all of Northeast Texas and Northwest Louisiana, should develop goals and policies that will help determine which are the mound sites most vulnerable to destruction, and which are the sites of most importance for immediate, short-term, and long-term protection.

The Jamestown (41SM54) and Boxed Springs (41UR30) sites, two of the three premier Caddoan mound centers in the Sabine River Valley of Northeast Texas, need top priority actions to insure that they will be protected and preserved, if at all feasible. The other premier mound center, Hudnall Pirtle (41RK4), is owned by The Archaeological Conservancy.

Hand in hand with the development of a protection and preservation plan is the development of an active research program at these Caddoan mound sites (cf. Story 1991; Perttula 1993a). The research program should consist of excavations at a sample of the different types of Caddoan mound sites in the Sabine River Valley as a means to assess their internal character and integrity, and also to examine the temporal, functional, and cultural context of the mounds, middens, borrow pits, and other types of features preserved in the archaeological record.

It is also important that these research efforts include the development of contemporary maps depicting the current condition of the properties, and these maps should be bolstered with the analysis of previous and recent aerial photographs of the sites. The research efforts need to be of sufficient scale that radiocarbon or thermoluminescence dates from interpretable mound or nonmound, fill zone, or sealed contexts be obtained from as many Caddoan mound sites as possible.

Known collections of cultural materials from Caddoan mound sites in the Sabine River Valley need to be thoroughly reanalyzed, photographed, and described so that this updated information becomes a useful aspect of the data base for the study of Caddoan archaeology in Northeast Texas and Northwest Louisiana. Along with the research efforts proposed for the Caddoan mound sites themselves, it is important to initiate intensive 
survey investigations in the areas immediately proximal to the mound sites to identify the contemporaneous Caddoan villages, hamlets, and farmsteads of those groups who constructed and used the mound sites for civic and ceremonial purposes. The intensity and scope of such a survey should be addressed as an aspect of the protection and preservation plan which may need to be developed for specific Caddoan mound sites in the region.

\section{Acknowledgments}

The work reported on herein was funded by the Texas Historical Commission pursuant to a Historic Preservation Fund grant made by the U.S. Department of the Interior, National Park Service to the Institute of Applied Sciences, University of North Texas; the author was Principal Investigator for the project.

Randy Nathan, Steve Gaither, Robert Cast, and Bob Skiles assisted the project through records searches, artifact analyses, surveying, and report preparation. Bonnie Yates contributed to the report editing, and was a great help in many other ways, as were Wanda Cast, Pam Carmichael, and Gerald Blow of the Institute of Applied Science's support staff.

I want to thank Mr. Sam Whiteside (now deceased) and Mr. Forrest Murphey for their willingness to discuss their work in the Sabine River Valley, and appreciate the help interested landowners, amateur archaeologists, and others provided in the study.

The Texas Archeological Research Laboratory, particularly Carolyn Spock, and the Louisiana Division of Archaeology, particularly Dr. Katherine Byrd and Philip G. Rivet, were most gracious in supplying copies of site forms and other inaccessible records on Sabine River mound sites for the project. John Ippolito provided useful background information on mound sites in the Sabine National Forest. Finally, Dr. James E. Bruseth and Ms. Nancy Kenmotsu of the Texas Historical Commission administered the project, and provided direction from its inception to completion. 
Brown, J.A.

1971 The Dimensions of Status in the Burials at Spiro. In Approaches to the Social Dimensions of Mortuary Practices, edited by J.A. Brown, pp. 92-112. Memoir No. 2. Society for American Archaeology.

Bruseth, J.E.

1991 Hudnall-Pirtle: An Early Caddoan Mound Complex in Northeast Texas. Caddoan Archeology Newsletter Volume II (No. 3), pp. 9-15. Austin. Bruseth, J.E. and T.K. Perttula

1981 Prehistoric Settlement Patterns at Lake Fork Reservoir. Texas Antiquities Permit Series Report No. 2. Southern Methodist University, Dallas, and Texas Antiquities Committee, Austin.

Davis, H.A., D.G. Wyckoff, and M.A. Holmes (editors)

1971 Proceedings of the Seventh Caddo Conference. Occasional Publications No. 1. Oklahoma Archeological Survey, University of Oklahoma, Norman.

Early, A.M.

1989 Profiteers and Public Archaeology: Antiquities Trafficking in Arkansas. In The Ethics of Collecting Cultural Property: Whose Culture? Whose Property?, edited by P.M. Messenger, pp. 39-50. University of New Mexico Press, Albuquerque.

Gibson, J.L.

1978 An archaeological reconnaissance of the Lower Sabine River Valley, Toledo Bend Dam to Gulf Intracoastal Waterway, Louisiana and Texas.University of Southwestern Louisiana, Center for Archaeological Studies, Report 4. Lafayette. 
Girard, J.

1991 Northwest Regional Archaeologist Studies Toledo Bend Area. Archaeology News, Vol. 8, No. 1, pp. 2-3. State of Louisiana, Division of Archacology, Office of Cultural Development, Department of Culture, Recreation and Tourism. Baton Rouge.

Guy, J.A.

1990 Previous Archeological Investigations. In The Archeology and Bioarcheology of the Gulf Coastal Plain, by D.A. Story et al., pp. 27-130. Arkansas Archeological Survey, Research Series No. 38. Fayetteville.

Ippolito, J.

1988 Personal communication with the author, October 25, 1988.

Jensen, H.P.

1968a Archeological Investigations in the Toledo Bend Reservoir 1966-1967. Report submitted by Southern Methodist University to the National Park Service, Contract No. 14-10-3:930-1.

1968b Coral Snake Mound, X16SA48. Bulletin of the Texas Archeological Society $39: 9-44$.

Johnson, L., Jr.

1987 A Plague of Phases: Recent Sociocultural Taxonomy in Texas Archeology. Bulletin of the Texas Archeological Society 57:1-26.

Kay, M., G. Sabo III, and R. Merletti

1989 Late Prehistoric Settlement Patterning: A View from Three Caddoan CivicCeremonial Centers in Northwest Arkansas. In Contributions to Spiro Archeology: Mound Excavations and Regional Perspectives, edited by J.D. Rogers, D.G. Wyckoff, and D.A. Peterson, pp. 129-157. Studies in Oklahoma's Past No. 16. Oklahoma Archeological Survey, Norman. 
Kenmotsu, N. and T.K. Perttula (editors)

1993 Archeology in the Eastern Planning Region, Texas: A Planning

Document. Cultural Resource Management Report 3. Texas Historical

Commission, Department of Antiquities Protection, Austin.

Kier, R.S., L.E. Garner, and L.F. Brown

1977 Land Resources of Texas: A Map of Texas Lands Classified According to Natural Suitability and Use Considerations. Land Resources Laboratory Series. Bureau of Economic Geology, The University of Texas at Austin.

Malone, J.

1972 Archeological Reconnaissance at Proposed Mineola Reservoir. Archaeological Survey Report 10. Texas Historical Survey Committee and Texas Water Development Board, Austin.

McClurkan, B.B., W.T. Field, and J.N. Woodall

1966 Excavations in Toledo Bend Reservoir, 1964-1965. Papers of the Texas Archeological Salvage Project, No. 8. Texas Archeological Salvage Project, University of Texas at Austin.

McClurkan, B.B., E.B. Jelks, and H.P. Jensen

1980 Jonas Short and Coral Snake Mounds: A Comparison. Louisiana Archaeology 6:173-206.

Pearce, J.T.

1920 Early Work in East Texas. MS on file, Texas Archeological Research Laboratory, Austin.

Perttula, T.K.

1989a A Study of Mound Sites in the Sabine River Basin, Northeast Texas and Northwest Louisiana. Final Report submitted to the Texas 
Historical Commission by the Institute of Applied Sciences, University of North Texas. Denton.

1989b The Looting and Vandalism of Archaeological Sites in East Texas: A Status Report. Texas Historical Commission, Office of the State Archeologist and Department of Archeological Planning \& Review. Austin.

1992 "The Caddo Nation": Archaeological and Ethnohistoric Perspectives. University of Texas Press, Austin.

1993a The Development of Agriculture in Northeast Texas before A.D. 1600. In Archeology in the Eastern Planning Region, Texas: A Planning Document, edited by N.A. Kenmotsu and T.K. Perttula, pp. 121-146. Cultural Resource Management Report 3. Texas Historical Commission, Department of Antiquities Protection, Austin.

1993b Mound Sites in Northeast Texas and Northwest Louisiana. In Archeology in the Eastern Planning Region, Texas: A Planning Document, edited by N.A. Kenmotsu and T.K. Perttula, pp. 251-252. Cultural Resource Management Report 3. Texas Historical Commission, Department of Antiquities Protection, Austin.

Perttula, T.K. and K.K. Gilmore

1988 Archaeological Survey along Mill Race Creek and Tributaries, Wood County, Texas: 1987-1988. Contributions in Archaeology No. 6. Institute of Applied Sciences, University of North Texas. Denton.

Perttula, T.K. and B.D. Skiles

1987 Cultural Resources Survey of the Darco Mine Permit Extension Area, Harrison County, Texas. Prewitt \& Associates, Inc., Reports of Investigations No. 58. Austin.

Perttula, T.K., B.D. Skiles, and B.C. Yates 
1993 Excavations at the Goldsmith Site (41WD208): Investigations of the Titus Phase in the Upper Sabine River Basin, Wood County, Texas. Bulletin of the Texas Archeological Society, Vol. 61. In press.

Perttula, T.K., B.D. Skiles, M.B. Collins, M.C. Trachte, and F. Valdez, Jr.

1986 "This Everlasting Sand Bed": Cultural Resources Investigations at the Texas Big Sandy Project, Wood and Upshur Counties, Texas.

Prewitt \& Associates, Inc., Reports of Investigations No. 52. Austin.

Rawick, G.P. (editor)

1979 The American Slave: A Composite Autobiography. Series 2 Supplement. Greenwood Press, Westport.

Rogers, J.D.

1982 Spiro Archeology: 1980 Research. Studies in Oklahoma's Past No. 9. Oklahoma Archeological Survey, Norman.

1983 Social Ranking and Change in the Harlan and Spiro Phases of Eastern Oklahoma. In Southeastern Natives and Their Pasts, edited by D.G. Wyckoff and J.L. Hofman, pp. 17-128. Studies in Oklahoma's Past No. 11. Oklahoma Archeological Survey, Norman.

1989 Settlement Context for Shifting Authority in the Arkansas Basin. In Contributions to Spiro Archeology: Mound Excavations and Regional Perspectives, edited by J.D. Rogers, D.G. Wyckoff, and D.A. Peterson, pp. 159-176. Studies in Oklahoma's Past No. 16. Oklahoma Archeological Survey, Norman.

Sabo III, G. and A.M. Early

1988 Prehistoric Culture History. In Human Adaptation in the Ozark-Ouachita Mountains, by G. Sabo II, A.M. Early, J.C. Rose, B.A. Burnett, L. Vogele, Jr., and J.P. Harcourt, pp. 34-120. Arkansas Archeological Survey, Research Series No. 31. Fayetteville. 
Scurlock, J.D.

1964 Archeological Reconnaissance at Toledo Bend Reservoir, 1962-1963

Season. Texas Archeological Salvage Project, University of Texas at Austin.

Submitted to the National Park Service, Contract 14-10-0333-956.

Sherrod, P.C. and M.A. Rolingson

1987 Surveyors of the Ancient Mississippi Valley: Modules and

Alignments in Prehistoric Mound Sites. Arkansas Archeological Survey, Research Series No. 28. Fayetteville.

Skiles, B.D. and T.K. Perttula

19891978 Archeological Investigations at the B.G. Price (41WD7) and J.O. McCreight (41WD9) Mounds, Wood County, Texas. In A Study of Mound Sites in the Sabine River Basin, Northeast Texas and Northwest Louisiana, by T.K. Perttula, pp. 93-98. Final Report submitted to the Texas Historical Commission by the Institute of Applied Sciences, University of North Texas. Denton.

Story, D.A.

1990 Cultural History of the Native Americans. In The Archeology and Bioarcheology of the Gulf Coastal Plain, by D.A. Story, J.A. Guy, B.A. Burnett, M.D. Freeman, J.C. Rose, D.G. Steele, B.W. Olive, and K.J. Reinhard, pp. 163-366. Arkansas Archeological Survey, Research Series No. 38.

Fayetteville.

1991 Some Comments on the Status of Caddoan Archeology. APR News \& Views, Volume 3, No. 2, pp. 17-18. Texas Historical Commission, Department of Archeological Planning and Review, Austin. 
Story, D.A. and D.G. Creel

1982 The Cultural Setting. In The Deshazo Site, Nacogdoches County, Texas, Volume 1: The Site, Its Setting, Investigation, Cultural Features, Artifacts of Non-Native Manufacture, and Subsistence Remains, edited by D.A. Story, pp. 20-34. Texas Antiquities Permit Series, No. 7. Texas Antiquities Committee, Austin.

Thurmond, J.P.

1985 Late Caddoan Social Group Identifications and Sociopolitical Organization in the Upper Cypress Basin and its vicinity, Northeastern Texas. Bulletin of the । Texas Archeological Society 54:185-200.

1990 Archeology of the Cypress Basin, Northeast Texas and Northwest Louisiana. Studies in Archeology 5. Texas Archeological Research Laboratory, The University of Texas at Austin.

Webb, C.H.

1959 The Belcher Mound, a Stratified Caddoan Site in Caddo Parish, Louisiana. Society for American Archaeology, Memoirs No. 16.

Webb, C.H. and R.R. McKinney

1975 Mounds Plantation (16CD12), Caddo Parish, Louisiana. Louisiana Archaeology 2:39-127.

Webb, C.H., F. Murphey, W.G. Ellis, and H.R. Green

1969 The Resch Site, 41HS16, Harrison County, Texas. Bulletin of the Texas Archeological Society 40:3-106.

Wilson, A.M. and A.T. Jackson

1930 Reconnaissance in Wood County, Texas August 10 to 24, 1930. Field notes on file, Texas Archeological Research Laboratory, Austin.

Woldert, W.A.

1932 East Texas. Four volumes, typescript on file. Tyler Public Library, Tyler, Texas. 


\title{
Patterns of Prehistoric Lithic Raw Material Utilization in the Caddoan Area: The Western Gulf Coastal Plain
}

\author{
TIMOTHY K. PERTTULA
}

\author{
Introduction
}

The prehistoric inhabitants of the Caddoan area utilized a wide variety of raw materials in the manufacture of lithic tools. Raw materials from as far away as the Texas Panhandle (Alibates chert and Tecovas jasper), southern Kansas (Kay County chert and Flint Hills chert), Nebraska (Nehewaka chert), and Tennessee (Dover chert) have been recovered in excavated lithic assemblages. Only in the last few years. however, have archaeologists begun to study the variability in Caddoan raw material types as a key to understanding prehistoric behavior (e.g., Banks and Winter 1975; Mallouf 1976; Vehik and Galm 1979; Wright 1980; Wyckoff 1963, 1965, 1967, 1968). This paper examines the lithic raw material data from a series of sites in the Lake Fork Reservoir in the Western Gulf Coastal Plain of Texas (Bruseth and Perttula 1979, 1981). The differential utilization of local versus nonlocal raw materials is evaluated, and the patterns of raw material use in Archaic and Caddoan lithic assemblages are examined to elucidate questions of regional interaction and tool use.

\section{Background}

Those areas characterized by a lack of naturally occurring lithic raw materials (Mississippi Valley lowlands) or by their presence in redeposited gravel beds (the Western Gulf Coastal Plain) are particularly suitable for the study of lithic raw material utilization. Local raw materials occur in gravel deposits of the Uvalde Gravels. These gravels were derived from extensive erosion of the High Plains in the Pleistocene and are composed principally of small quartzites, chert, and petrified wood cobbles. Nonlocal raw materials are easily isolated through visual inspection, and locations of local raw material outcrops or gravel deposits, if present, can be predicted if the area geomorphology is known.

There are four particular uplift areas adjacent to the Western Gulf Coastal Plain that provide a number of lithic raw materials pertinent to this study. They are the Ozark, Ouachita, Arbuckle, and Edwards areas (Figure 7.1). Within each area there exists a relatively discrete and homogeneous set of lithic raw materials available and suitable for prehistoric exploitation. Excavations of sites within these different physiographic and geological regions have demonstrated that raw

Friends of Northeast Texas Archaeology, Special Publication No. 1 (1995) 


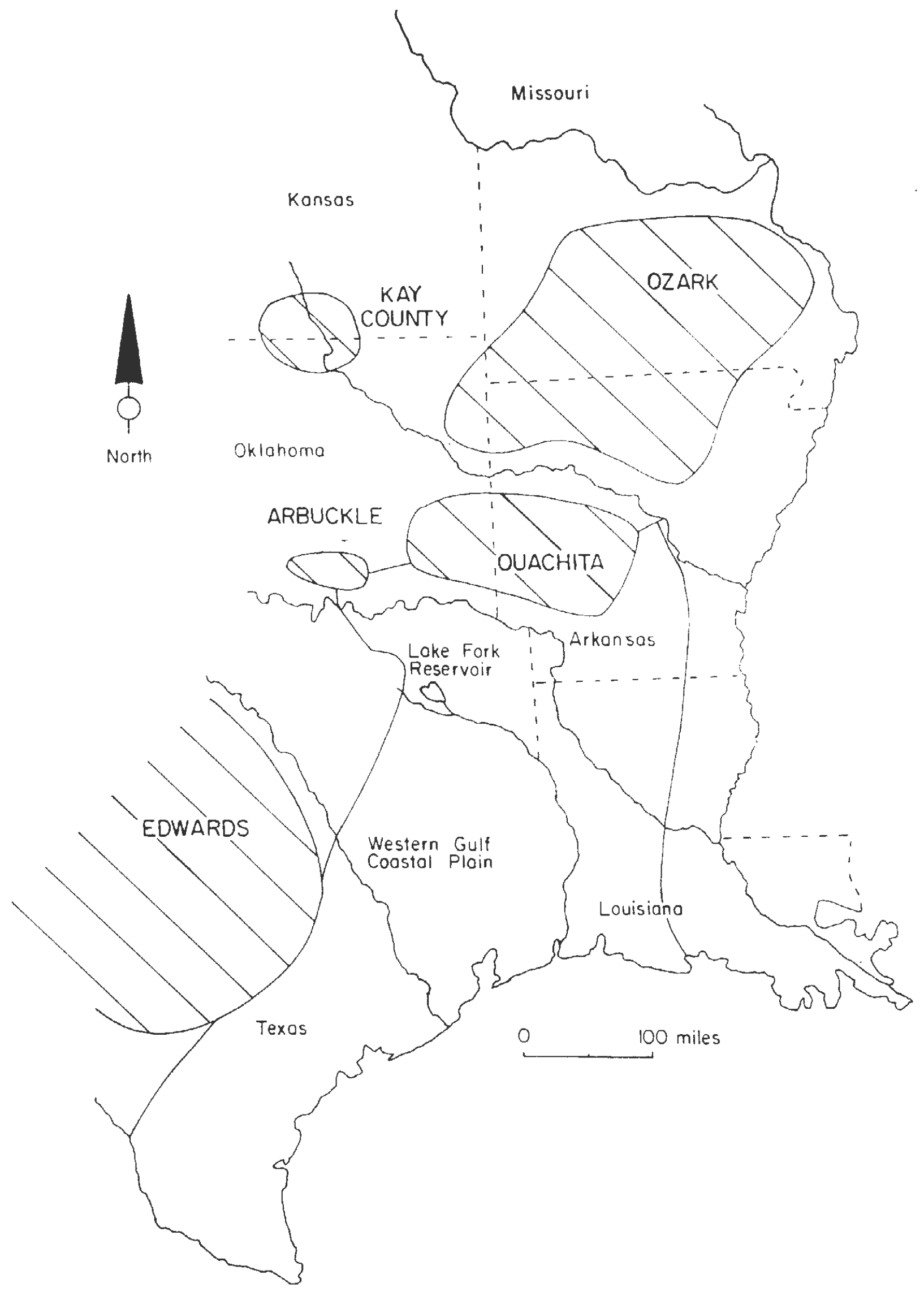

Figure 7.1 Lithic raw material source areas. 
material utilization was relatively homogeneous temporally and spatially (e.g., Vehik 1979:490,494).

A Model Of Nonlocal Lithic Raw Material Utilization

At present, prehistoric lithic raw material utilization in the Caddoan area, as for most other areas of the Southeast, is imperfectly understood. More detailed raw material identification procedures need to be implemented (cf. Luedtke 1979) across a wide area of the Gulf Coastal Plain and adjacent uplifts to confirm the visual identifications presented in most recent Caddoan studies (Bobalik 1977; Calm 1978; Mallouf 1976). Refinements in data are necessary. but perhaps of equal importance are developments in model building.

The model that follows is concerned with the relationship between changes in lithic raw material utilization and changes in settlementsubsistence systems. Following precepts initially suggested by Grady (1978) for the Archaic period in Texas, the model is further expanded to deal with the Early Ceramic and Caddoan occupations of the Western Gulf Coastal Plain (see Bruseth and Perttula 1981:111 and Table 6-8). Grady (1978) has argued that differences in lithic raw material utilization in the Archaic period in east central Texas relate directly to the establishment of more regionally specialized exchange systems through time. He postulates that during the Late Archaic period ( $c a$. 2000 B.C. - A.D. 1) exchange occurred among cultural groups and communities within one overall exchange network, while during the Early and Middle Archaic (ca. 8000-2000 B.C.) exchange took place within several distinct networks. For this discussion, an exchange network refers to the specific exchange of goods, information, etc., between linked groups or series of groups.

This pattern is seen by Grady to be the result of the evolutionary development of a Primary Forest Efficiency economic strategy (Caldwell 1958) in the area during the Archaic Period. In the Early and Middle Archaic, the generalized economy of hunting and gathering involved a wide territory of effective group exploitation. Interaction with adjacent groups therefore involved the incorporation of larger areas into an overall exchange network composed of a number of cultural groups.

The effective network was synonymous with the maximum range of preferred exploitation, which was a geographically extensive area. The generalized nature of these Early and Middle Archaic economies, combined with a mobile settlement system and a flexible exchange system, allowed a simple linear exchange pattern to develop with members of adjacent interaction spheres. Some of these areas would have possessed fine-grained silicates--superior to local cherts--that the exchange network would have made available. Assuming that lithic raw materials were critical resources and high quality cherts were preferred for tool manufacture because of their ease of working, then Early/Middle Archaic tool assemblages would be expected to include significant percentages of nonlocal raw materials.

During the Late Archaic in the Western Gulf Coastal Plain, native economies were expanding and diversifying (e.g.. Christenson 1980). Exotic cucurbits and wild plant foods may well have been incorporated into the diet, since they were in adjacent areas at this time. The intensive foraging characteristics of this adaptation (Winters 1974) combined with apparent population growth resulted in definable terri- 
tories within the major streams in the area. Thus, a relatively stable and compact pattern of less mobile populations may be characteristic.

The reduction of exploited territory had ramifications in the exchange system. Whereas Early/Middle Archaic period exchange was suggested to have taken place across larger areas and different exchange systems, Late Archaic exchange became more regionally oriented, less flexible, and generally confined within a common economic sphere composed of a series of territorial groups with complementary adaptive strategies (Grady 1978). Thus, exchange of nonlocal lithic raw materials and tool forms would be replaced by materials that reflect the raw materials available within a much-reduced area. Less access to nonlocal materials is compensated for by a more well-developed, stabilized pattern of exchange that ensures constant access to local critical resources. Exchange patterns during this period should emphasize local raw materials, and it is expected that tool assemblages will consist of higher percentages of local materials and tool forms than the preceding periods.

In the Midwest, a highly developed pattern of exchange of trade goods is characteristic of the Late Archaic period (Winters 1968). Marine shell, nonlocal cherts, and elements of the lapidary industry occur in burial associations and indicate occasional wide-ranging interregional exchange. Whether such a pattern of exchange also exists in the Late Archaic in the Western Gulf Coastal Plain is not known (Story 1981).

Early Ceramic (A.D. 1-800) raw material utilization patterns are suggested to be comparable to Late Archaic components primarily as a result of the same restricted territorial exploitation/exchange relationships and territorial autonomy characteristic of both periods. No centralized loci for the handling, controlling, and dispersing of nonlocal materials are known, and it is likely that the generally low degree of hierarchical differentiation reflected in the archaeological record will correlate with lower frequencies of exchanged valuables (e.g.. Hodder 1980). Of course, where there is a greater burial and/or settlement evidence of hierarchy, higher frequencies of nonlocal goods will be expected. Such would seem to be the case along the lower Sabine and Angelina rivers (Jelks 1965).

The innovation of mound construction in the Early Caddoan period had an important effect on the character of exchange in the Western Gulf Coastal Plain. Evidence of elaborate ceremonial activities in east Texas around A.D. 800 (Story 1972) indicates the development of a highly sophisticated and well-organized exchange network. This network probably encompassed the majority of the Caddoan area. The increased organizational complexity and hierarchical differentiation within this period, and the well-developed sociopolitical integration so characteristic of the Early Caddoan period, are reflected in the archaeological record by elaborations in social and ceremonial activities in which the procurement of nonlocal raw materials (at least in the major mound centers) plays a large role. While it is not clear how raw materials were exchanged on an intraregional basis, it is likely that the mound centers had a vital function in their procurement and ultimate distribution to lower-level components (villages and hamlets) within the overall system.

On an interregional level, exchange was probably between distinct territorial units (phases?) within the larger regional area of cultural groups with similar adaptive strategies (Brain 1976; Perttula 1980), as well as with different cultural groups (e.g.. The Mississippi Valley). 
With the cessation of most mound construction in east Texas in the Late Caddoan Period (Ca. A.D. 1300-1400) it is presumed that exchange once again became more localized (Story 1981). Without the mound centers' functioning as foci of resource procurement and redistribution, particularly from distant (i.e.. Ozark Highlands) resource locations, a more localized and intraregionally based, but not necessarily less complex, exchange network developed. The shift toward a smaller network had its basis in the relatively specialized nature of Late Caddoan agricultural economies. These economies stressed cohesive social networks with strong, intraregional community ties geared to the development of local economic security. Intraregional exchange was both necessary and sufficient, while interregional exchange controlled by local and/or regional elites remains characteristic only in the major alluvial valleys. Hence, it is to be expected that in those areas where mound construction ceased, such as the area under consideration here. local assemblages should exhibit higher frequencies of local raw materials than in the preceding Early Caddoan phase. Within the major river systems of the Caddoan area, such as the Red, Ouachita, and Little Rivers, the exchange network presumably remained unchanged up to about A.D. 1700, judging from the continuation of earthwork construction and elaborate ceremonial activities (Wyckoff 1974; Webb 1959).

Nonlocal lithic raw materials are very common in historic components in the Western Culf Coastal Plain (Mallouf 1976:44). Materials such as Alibates and Kay County cherts are well known in southerr: Plains late prehistoric and historic occupations (Cooper 1975:185-194). This distribution indicates a much wider exchange network than existed during all previous periods except for the Early and Middle Archaic. Without detailed knowledge of how horses affected exchange patterns or the supposed role of the Wichita and Plains Apache as middlemen, distributors, and procurers of these nonlocal raw materials, (see Hofman 1978), the exact nature of the exchange process cannot now be specified. Nevertheless, it appears that the exchange network during the historic period may be of a different order of magnitude than that of preceding periods. This is reflected in the wider movement of $\mathrm{re}^{-}$ sources and in the differences in the resources being exploited.

There were two main patterns in the historic exploitation and exchange of lithic materials in the southern Plains and adjacent woodlands. The first is the direct exploitation of a lithic raw material source by a small segment of a larger cultural group, with exchanges of lithic materials taking place as groups met at particular prescribed times of the year (see Hartley and Miller 1977:258; Reher and Frison 1980:130; Stanford 1978). The second pattern consists of indirect exploitation and localized exchange within particular expanded networks and zones of distribution.

The first pattern seems to be characteristic of the more mobile bison-hunting inhabitants of the mixed-grass and short-grass high plains of Texas and Oklahoma, and the second pattern of the sedentary bison and/or deer hunting horticulturists of the prairie-woodland interface (Norteno focus). The former pattern would be manifest in the archaeological record as site assemblages where distant nonlocal lithic materials occur predominantly or exclusively (see Ferring and Vernon 1978:346; Hughes and Willey 1978:253, 281-282). The latter pattern would be much like that of earlier ceramic phases with high percentages of local raw materials and corresponding lower frequencies of nonlocal materials when compared to the more mobile populations. 
In summary, a cyclical pattern of nonlocal raw material utilization is envisioned, with quantitative changes through time. Higher percentages of nonlocal materials are expected, then, in Archaic II (late Middle Archaic), Early Caddoan, and Historic components, and correspondingly lower in Late Archaic, Early Ceramic, and Late Caddoan components in the Lake Fork area specifically. The applicability of such a model to the Western Gulf Coastal Plain as a whole will be considered below.

These changes are argued to be the result of corollary developments in subsistence strategies, elaborations in social and ceremonial activities and related exchange activity, and territorial constraints.

Utilizing only sites from a limited area, the present analysis essentially provides sufficient control over the range of raw materials (both local and nonlocal sources) available for utilization at any one temporal period. Granted that local raw materials were abundant and apparently easily procured from within a $10-15 \mathrm{~km}$ radius from any site in the Lake Fork Reservoir, general changes in raw material utilization between and within particular periods are most likely the result of prescribed patterns of resource utilization and exploitation.

The Lake Fork Area

The archaeological assemblages considered herein consist of a series of spatially and temporally discrete components of Archaic through Late Caddoan period occupations recovered from 1976 and 1978 excavations at Lake Fork Reservoir in northeast Texas (Figure 7.1), on Lake Fork Creek, a major tributary to the Sabine River. The project was conducted by the Archaeology Research Program, Southern Methodist University, and was funded by the Sabine River Authority and the Texas Antiquities Committee under a state of Texas Antiquities Permit. A complete description of the project area, the sites, and the field and laboratory methods has been provided elsewhere (Bruseth and Perttula 1979, 1980, 1981).

The analysis of lithic raw materials from Lake Fork archaeological assemblages began with a preliminary sorting of lithic tools and debris. A number of working raw material categories were established. These categories were checked by consultations with Larry D. Banks, U.S. Army Corps of Engineers Archaeologist in Dallas, Texas. Banks pointed out raw material identification errors, provided descriptive and geological information, and indicated source locations.

Following this, relevant literature concerning lithic raw materials was examined to specify, where possible, the area of natural occurrence (e.g., certain river gravels, formation outcrops, or quarries), within particular regional lithic raw material areas, of each of the defined stone types.

Twenty raw material types were identified in the Lake Fork archaeological assemblages. On the basis of macroscopic observation, each type was separated by color, texture and grain size, translucency, and inclusions. It was possible to specify natural source distributions for most raw material types and to suggest probable natural source distributions for the remainder. However, the degree of confidence in assigning source areas varies somewhat with raw material categories. Thirteen types are categorized as nonlocal, given the location of the Lake Fork area relative to natural source distributions. The remaining seven raw material types are locally available in Yalde gravels. 
Two raw material types each have been identified in Lake Fork assemblages from the Ozark and Arbuckle regions, one type from the Edwards Plateau region, and eight types from the Ouachita Mountain region (Table 7.1). Except for the chert types in the Edwards Plateau and Ozark regions, the remainder of the nonlocal raw materials could be obtained in Red River gravels approximately $100 \mathrm{~km}$ north of the Lake Fork Creek area. The Boggy, Washita, Kiamichi, Little, and Red Rivers carry Ouachita and Arbuckle lithic raw materials as gravels. Edwards Plateau chert outcrops are approximately 200-250 km or more southwest (Henry et al. 1980), while Ozark lithic raw materials are carried in Arkansas River (and related stream) gravels 250-300 km north of Lake Fork Creek Reservoir. Raw material descriptions of the nonlocal types are provided in Table 7.1.

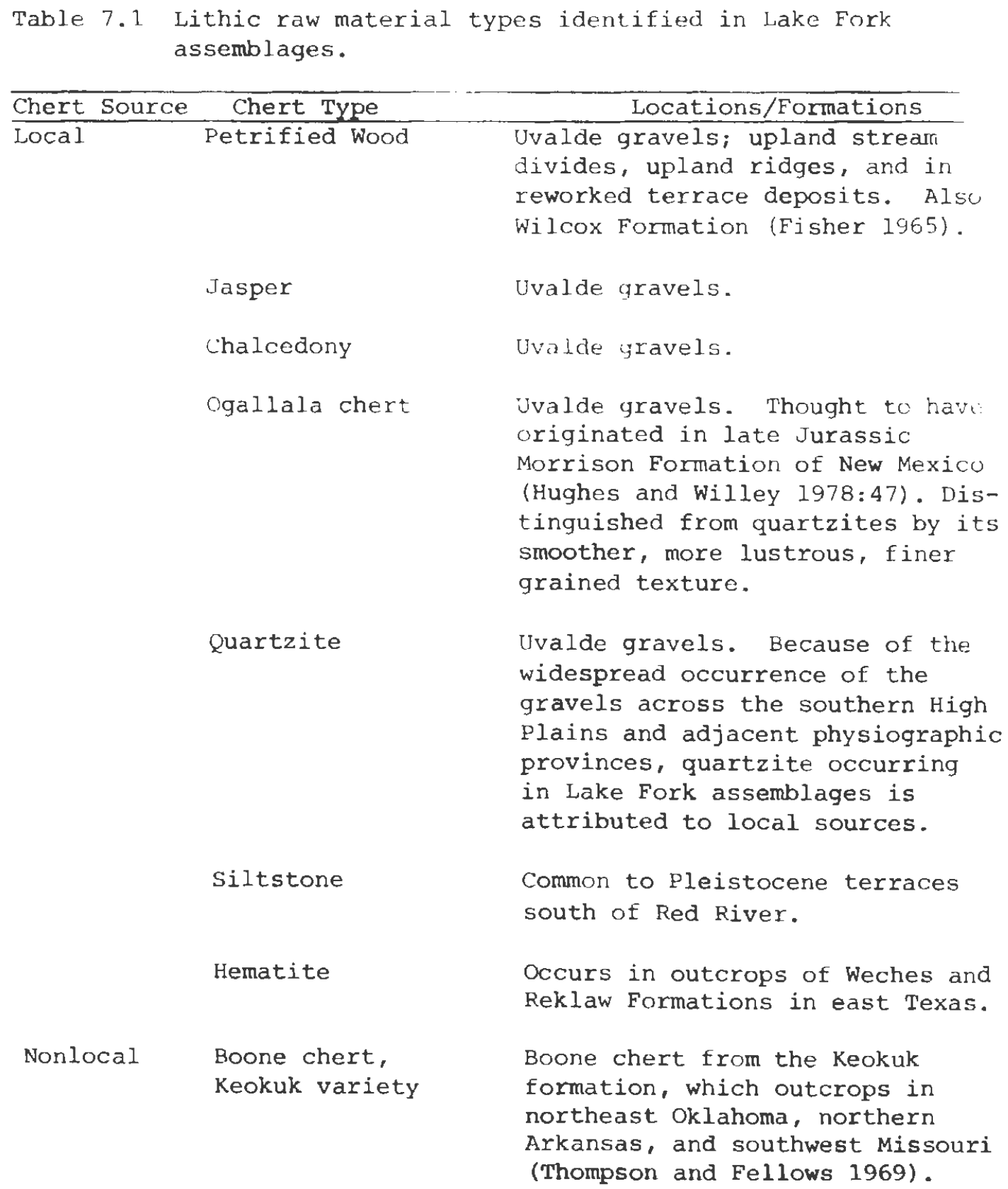

Boone chert from the Keokuk formation, which outcrops in northeast Oklahoma, northern Arkansas, and southwest Missouri (Thompson and Fellows 1969). 
Table 7.1 Lithic raw material types identified in Lake Fork assemblages (continued).

\begin{tabular}{|c|c|c|}
\hline Chert Source & Chert Type & Locations/Formations \\
\hline \multirow[t]{5}{*}{ Nonlocal } & Gray chert & $\begin{array}{l}\text { Northeast Oklahoma (Illinois } \\
\text { River); possibly Ouachita } \\
\text { Mountains as well (Lintz 1979: } \\
\text { 30). }\end{array}$ \\
\hline & Novaculite & $\begin{array}{l}\text { The Arkansas Novaculite forma- } \\
\text { tion which runs from Hot Springs, } \\
\text { Arkansas, to the Little River } \\
\text { and Glover Creek areas of south- } \\
\text { east oklahoma. Outlier outcrops } \\
\text { occur along Muddy Boggy Creek } \\
\text { in Atoka County, oklahoma, and } \\
\text { in the Potato Hills area north } \\
\text { of the Kiamichi River. }\end{array}$ \\
\hline & Woodford chert & $\begin{array}{l}\text { Ouachita Mountains; known to } \\
\text { outcrop in five localities in } \\
\text { the western Winding stair } \\
\text { Mountains in southeast } \\
\text { oklahoma and in gravel bars of } \\
\text { the Red River. }\end{array}$ \\
\hline & $\begin{array}{l}\text { Big Fork chert, } \\
\text { Black and } \\
\text { Green varieties }\end{array}$ & $\begin{array}{l}\text { Ordovician Big Fork Formation, } \\
\text { which outcrops in various } \\
\text { sections in southeast Oklahoma } \\
\text { and on Kiamichi and Red River } \\
\text { gravel bars. }\end{array}$ \\
\hline & Black chert & $\begin{array}{l}\text { This chert occurs as gravels in } \\
\text { the Ouachita Mountain drainages } \\
\text { and in Red River gravels ( } \mathrm{L} \text {. } \\
\text { Banks, personal communication). } \\
\text { Stanley Shale Formation, which } \\
\text { outcrops from the Little River } \\
\text { in Oklahoma east-northeast to } \\
\text { the Arkansas state line. }\end{array}$ \\
\hline \multirow[t]{3}{*}{ Nonlocal } & $\begin{array}{l}\text { Quartzitic sand- } \\
\text { stone and } \\
\text { weathered } \\
\text { metamorphic rock }\end{array}$ & $\begin{array}{l}\text { Outcrops in the Stanley Shale and } \\
\text { Jack Fork Sandstone formations } \\
\text { (Flawn et al. 1961). }\end{array}$ \\
\hline & Quartz & $\begin{array}{l}\text { Occurs in a } 40-50 \mathrm{~km} \text { wide belt } \\
\text { from Little Rock, Arkansas, to } \\
\text { Broken Bow, Oklahoma (Rolingson } \\
\text { 1978). }\end{array}$ \\
\hline & Frisco chert & $\begin{array}{l}\text { Frisco Limestone Formation of } \\
\text { Pontotoc and Coal counties in } \\
\text { south-central oklahoma in the } \\
\text { Arbuckle Mountain region. It } \\
\text { also occurs more rarely in } \\
\text { Sequoyah County in northeast } \\
\text { oklahoma (Amsden } 1961: 25 \text { ). }\end{array}$ \\
\hline
\end{tabular}


Table 7.1 Lithic raw material types identified in Lake Fork assemblages (continued).

\begin{tabular}{|c|c|c|}
\hline Chert Source & Chert Type & Locations/Formations \\
\hline & $\begin{array}{l}\text { Honey-colored } \\
\text { chert }\end{array}$ & $\begin{array}{l}\text { Derived from a number of Arbuckle } \\
\text { Mountain rock formations ( } \mathrm{L} \text {. } \\
\text { Banks, personal communication). } \\
\text { Occurs as river-gravels of the } \\
\text { Boggy, Washita, and Red Rivers. } \\
\text { Lowrance chert (e.g., Wyckoff } \\
\text { 1973:70) closely resembles this } \\
\text { material. }\end{array}$ \\
\hline & Edwards chert & $\begin{array}{l}\text { Outcrops in the Lower Cretaceous } \\
\text { Edward Formation of the Edwards } \\
\text { Plateau and southern Llano } \\
\text { Estacado. This chert does not } \\
\text { occur or outcrop within the en- } \\
\text { tire extent of the Edwards Forma- } \\
\text { tion but is present predominantly } \\
\text { south and southwest of the Brazos } \\
\text { and Bosque Rivers (Henry et. al. } \\
\text { 1980). }\end{array}$ \\
\hline
\end{tabular}

Temporal Trends

Based on the analysis of over 25,000 pieces of lithic debris and 1,000 tools from 30 prehistoric components, clear trends in the differential utilization of nonlocal raw materials are evident. Though the representation of nonlocal lithic raw materials differs from tools to lithic debris in absolute frequency for all components, the same general trends are shown (Tables 7.2 and 7.3 ).

All Archaic components have low percentages of nonlocal lithic debris $(X=108)$; much lower than for tools at each component. There is an absolute decrease in the utilization of nonlocal raw materials from the Late Archaic period (ca. 2000 B.C.- 1 A.D.) through the Early Ceramic period (1-800 A.D.), when the trend reaches its nadir. The differential representation of nonlocal raw materials from tools to lithic debris is also present in Early Ceramic components but is not as pronounced as in Late Archaic (Archaic II1) components. An absolute increase in nonlocal raw materials is clearly correlated with Early Caddoan (ca. A.D. 800-1350) components, generally two or three times higher in magnitude. In fact, approximately half of the raw material utilized in tool production is nonlocal, and up to 808 of the small projectile points were manufactured from nonlocal materials. From other lines of evidence, it is suggested that nonlocal raw material utilization peaks ca. A.D. 1250, or the later part of the Early Caddoan period as defined here (e.g.. Perttula 1981). The utilization of nonlocal lithic raw materials decreases again in the Late Caddoan period (A.D. 1350-1600). The analysis of the lithic raw materials from the Gilbert site, located in the upper portion of Lake Fork Reservoir, indicates an increase in the utilization of nonlocal materials from the 
Table 7.2 Lithic raw material data for all the assemblages.

Temporal Period,

Components

Cores Tools

Debris

\begin{tabular}{|c|c|c|c|c|c|c|c|c|c|c|c|c|}
\hline & 8 & $\begin{array}{c}8 \\
\text { Non- }\end{array}$ & 8 & & 8 & $\begin{array}{c}8 \\
\text { Non- }\end{array}$ & 8 & & 8 & $\begin{array}{c}8 \\
\text { Non- }\end{array}$ & 8 & \\
\hline Archaic II & Local & local & UID & $\mathbf{N}$ & Local & local & UID & $\mathbf{N}$ & Local & local & UID & $\mathbf{N}$ \\
\hline Wd 19 II $^{\mathrm{a}}$ & 93.0 & 7.0 & & 57 & 69.3 & 28.5 & 2.2 & 186 & 91.5 & 5.4 & 3.1 & 4195 \\
\hline \multicolumn{13}{|l|}{$\begin{array}{l}\text { Archaic } \\
\text { III }\end{array}$} \\
\hline WD $64 / 69 \mathrm{H}$ & 94.4 & 5.6 & & 18 & 69.6 & 26.1 & 4.3 & 69 & 82.7 & 15.5 & 1.8 & 651 \\
\hline WD 16 D & & N/A & & & 76.0 & 20.0 & 4.0 & 25 & 85.9 & 12.2 & 1.9 & 581 \\
\hline WD $95 \mathrm{E}$ & 100.0 & & & 3 & 85.7 & 9.5 & 4.8 & 21 & 85.7 & 12.3 & 2.0 & 452 \\
\hline WD $16 \mathrm{C}$ & 100.0 & & & 1 & 70.0 & 30.0 & & 10 & 86.5 & 11.4 & 2.1 & 423 \\
\hline WD $87 \mathrm{C}$ & 100.0 & & & 1 & 83.3 & 16.7 & & 6 & 92.6 & 6.2 & 1.2 & 162 \\
\hline \multicolumn{13}{|l|}{$\begin{array}{l}\text { Early } \\
\text { Ceramic }\end{array}$} \\
\hline WD $39 \mathrm{E}$ & & $\mathrm{N} / \mathrm{A}$ & & & 76.4 & 17.7 & 5.9 & 17 & 92.1 & 6.6 & 1.3 & 379 \\
\hline WD $39 \mathrm{~F}$ & & $\mathrm{~N} / \mathrm{A}$ & & & 75.0 & 25.0 & & 12 & 90.3 & 8.3 & 1.4 & 145 \\
\hline RA 20 & 85.7 & & 14.3 & 7 & 83.1 & 16.9 & & 71 & 90.2 & 7.4 & 2.4 & 1741 \\
\hline WD $16 \mathrm{~A}$ & 94.7 & 5.3 & & 19 & 66.2 & 21.4 & 12.4 & 178 & 84.3 & 13.5 & 2.2 & 4098 \\
\hline WD $16 \mathrm{~B}$ & 100.0 & & & 1 & 71.3 & 28.7 & & 7 & 89.6 & 12.9 & 2.5 & 487 \\
\hline WD $19 \mathrm{I}$ & 98.4 & 1.6 & & 63 & 90.3 & 9.1 & 0.6 & 154 & 89.0 & 9.2 & 1.8 & 2471 \\
\hline \multicolumn{13}{|l|}{$\begin{array}{l}\text { Early } \\
\text { Caddoan }\end{array}$} \\
\hline WD $39 \mathrm{~A}$ & 100.0 & & & 4 & 52.9 & 37.8 & 9.3 & 140 & 58.9 & 29.0 & 12.1 & 5772 \\
\hline WD $39 \mathrm{~B}$ & & $\mathrm{~N} / \mathrm{A}$ & & & 44.4 & 50.0 & 5.6 & 18 & 65.7 & 29.2 & 5.1 & 611 \\
\hline WD $39 \mathrm{C}$ & 80.0 & 20.0 & & 5 & 47.6 & 52.4 & & 21 & 61.8 & 34.7 & 3.5 & 665 \\
\hline WD $64 / 69 \mathrm{C}$ & 100.0 & & & 1 & 60.0 & 40.0 & & 10 & 62.7 & 33.0 & 4.3 & 299 \\
\hline WD $64 / 69 \mathrm{E}$ & 100.0 & & & 2 & 30.0 & 66.7 & 3.3 & 30 & 53.8 & 40.5 & 5.7 & 493 \\
\hline WD $64 / 69 \mathrm{~F}$ & & 100.0 & & 1 & 33.3 & 66.7 & & 3 & 67.1 & 30.2 & 2.7 & 73 \\
\hline WD 87 A & 85.7 & 14.3 & & 7 & 61.1 & 27.8 & 11.1 & 18 & 84.3 & 13.2 & 2.5 & 159 \\
\hline WD $95 \AA$ & & $\mathrm{N} / \mathrm{A}$ & & & 57.1 & 28.7 & 14.3 & 7 & 74.2 & 22.0 & 3.8 & 132 \\
\hline WD $95 \mathrm{~B}$ & & $N / A$ & & & 100.0 & & & 2 & 64.7 & 30.2 & 5.1 & 136 \\
\hline WD $95 \mathrm{C}$ & & $\mathrm{N} / \mathrm{A}$ & & & 50.0 & 50.0 & & 6 & 80.0 & 18.5 & 1.5 & 130 \\
\hline WD $95 \mathrm{D}$ & 100.0 & & & 1 & 33.3 & 66.7 & & 6 & 71.3 & 25.1 & 3.6 & 303 \\
\hline WD 50 & 100.0 & & & & 43.7 & 50.0 & 6.3 & 16 & 59.6 & 38.5 & 1.9 & 208 \\
\hline \multicolumn{13}{|l|}{$\begin{array}{l}\text { Late } \\
\text { Caddoan }\end{array}$} \\
\hline WD $64 / 69$ A & & $\mathrm{N} / \mathrm{A}$ & & & 50.0 & 50.0 & & 2 & 82.6 & 13.3 & 4.1 & 46 \\
\hline WD $64 / 69 \mathrm{~B}$ & 100.0 & & & 1 & 100.0 & & & 2 & 73.0 & 24.9 & 2.1 & 96 \\
\hline WD $64 / 69 \mathrm{D}$ & 100.0 & & & 2 & 40.0 & 60.0 & & 10 & 76.0 & 20.1 & 3.9 & 179 \\
\hline WD $83 \mathrm{~A}$ & 100.0 & & & 1 & 40.0 & 60.0 & & 5 & 78.8 & 16.5 & 4.7 & 85 \\
\hline WD $83 \mathrm{~B}$ & & $\mathbf{N} / \mathbf{A}$ & & & 80.0 & 20.0 & & 5 & 82.9 & 12.4 & 4.7 & 64 \\
\hline WD $99 / 100$ & 100.0 & & & 4 & 65.4 & 19.2 & 15.4 & 26 & 76.6 & 20.4 & 3.0 & 265 \\
\hline
\end{tabular}

${ }_{\text {Al1 }}$ components are preceded by the prefix $\mathrm{x} 41$. $\mathrm{x}$ refers to sites in the state of Texas recorded by SMU, and 41 is the state number. WD is Wood County, RA is Rains County. 
Table 7.3 Sumary data on the 11thic materials by temporal period.

\begin{tabular}{|c|c|c|c|c|c|c|c|c|c|}
\hline \multirow[t]{4}{*}{ Temporal Period } & \multicolumn{3}{|c|}{ Cores $(\bar{x})$} & \multicolumn{3}{|c|}{ Tools $(\bar{X})$} & \multicolumn{3}{|c|}{ Debr1s $(\bar{X})$} \\
\hline & 8 & 8 & 8 & 8 & 8 & 8 & 8 & 8 & 8 \\
\hline & \multicolumn{3}{|c|}{ Non- } & \multicolumn{3}{|c|}{ Non- } & \multicolumn{3}{|c|}{ Non- } \\
\hline & Local & local & UID & Local & local & UID & Local & $10 \mathrm{cal}$ & UID \\
\hline Archalc II & 93.0 & 7.0 & & 69.3 & 28.5 & 2.2 & 91.5 & 5.4 & 3.1 \\
\hline $\begin{array}{l}\text { Archaic III } \\
\text { (Late Archaic) }\end{array}$ & 95.7 & 4.3 & & 74.1 & 22.1 & 3.8 & 85.6 & 12.5 & 1.9 \\
\hline Early Ceramic & 96.7 & 2.2 & 1.1 & 78.1 & 16.4 & 5.5 & 88.5 & 9.5 & 2.1 \\
\hline Early Caddoan & 86.4 & 13.6 & & 49.4 & 43.7 & 6.9 & 63.2 & 29.7 & 9.1 \\
\hline Late Cađdoan & 100.0 & & & 62.2 & 34.9 & 2.9 & 78.3 & 17.9 & 3.8 \\
\hline
\end{tabular}

Late Caddoan period to the Historic period comparable, if not greater, to that from the Early Ceramic to Early Caddoan period. Only 2.88 of the small projectile points and about 128 of the lithic debris were of local gravel materials (Allen et al. 1967: Table 9).

Trends in Use of Raw Materials from Different Regional Sources

Nonlocal Raw Materials

The utilization of raw materials from the different lithic regions shows a number of apparent changes through time (Table 7.4). First, Edwards and Ouachita materials dominate every temporal period. Ozark region cherts have the lowest representation, which is not unexpected given the long distance $(300 \mathrm{~km})$. from Lake Fork. Nevertheless, Ozark materials are a consistent component in all assemblages with mediocre to good sample sizes. Cherts from the Arbuckle region, which would be available in the Red River gravels downstream from the Washita and Blue Rivers (ca. $100 \mathrm{~km}$ north of Lake Fork), consistently rank third in utilization behind Edwards and Ouachita types. While sample sizes obviously have an influence on fluctuations, the presence of Ozark region materials, especially Keokuk chert, does seem to be more frequent in the later portions (after A.D. 1200) of the Early Caddoan period, and the Late Caddoan period, while Arbuckle material in general seems to increase at the beginning of the Early Caddoan period (Bruseth and Perttula 1981: Tables 6-10).

It would be worthwhile to consider what these fluctuations represent in terms of interregional exchange and cylical patterns of raw material availability (e.g.. Wright and Zeder 1977:238). Such patterns of different regional emphasis should become more apparent when better dated, and larger and comparable samples can be obtained. 
Table 7.4 Ut111zation of nonlocal lithic raw material by regional areas.

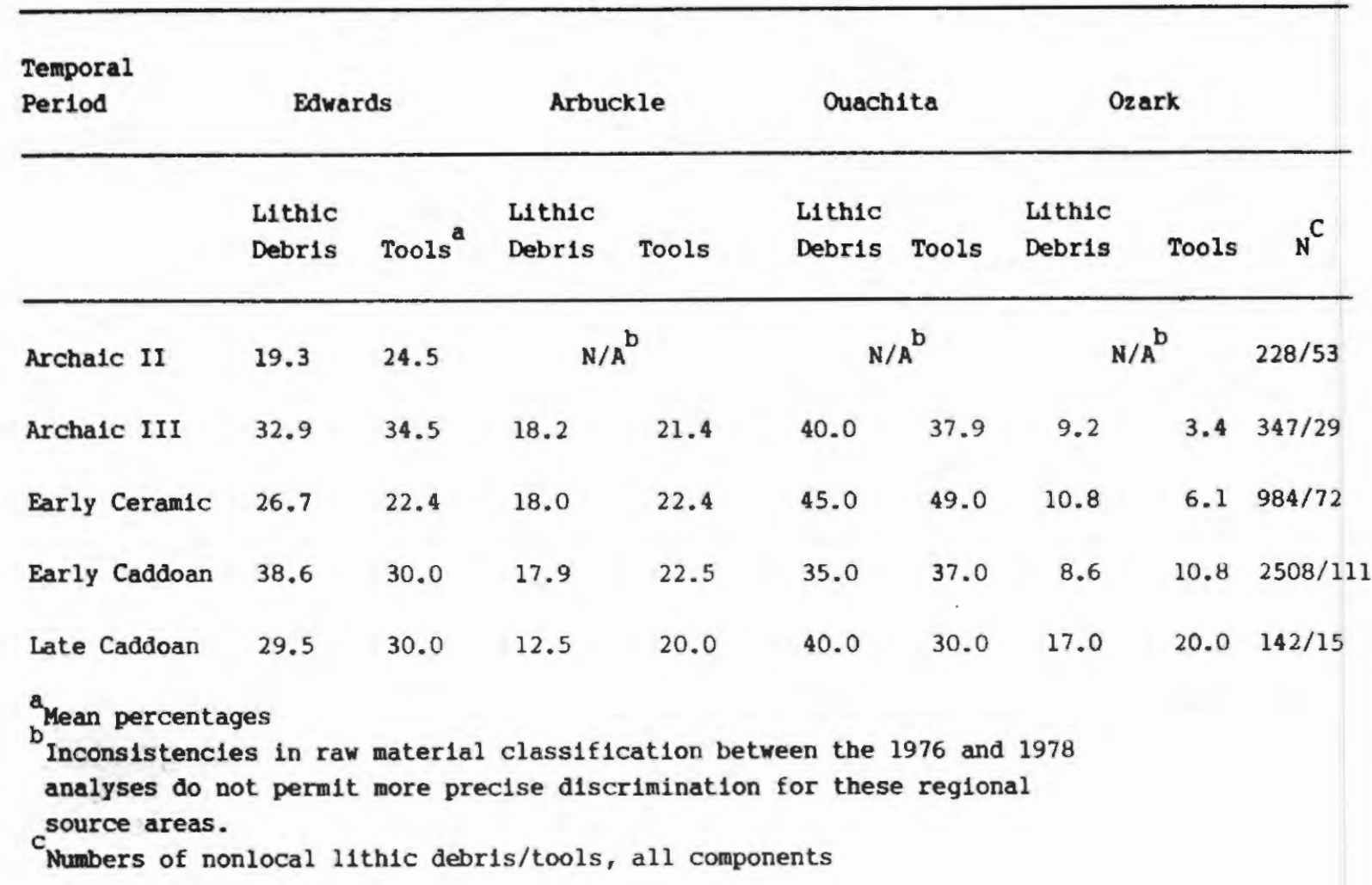

\section{Local Raw Materials}

Ogallala chert, quartzite, and petrified woods are the three commonly utilized local raw materials throughout all temporal periods at Lake Fork (Table 7.5). Jasper and chalcedony are only infrequently represented, primarily during the Early Caddoan period. It is likely that the low representation of jasper and chalcedony is due, in part, not to their absolute frequency in Uvalde Gravels, but to the fact that most pebbles are too small for effective prehistoric utilization. The notable increase in the frequency of jasper utilization during the Early Caddoan period may reflect procurement from another nonlocal source. Jasper, both red and yellow, is common in Red River gravels (Mallouf 1976:51) and could have been included in transactions involving other nonlocal materials traded from the Red:River Valley to the interior areas of East Texas. Except for the apparent higher utilization of petrified wood during the Archaic II period, the utilization of the three main local raw material types is consistent through time. However, differences in frequency representation between components demonstrated to be contemporan wous parts of a larger site cluster (i.e.., WD 39A/WD39B and WD 83A/WD83B) indicate that diferences in utilization of local materials were also, in part, the result of functional parameters and different disposal modes rather than solely temporal factors.

Functional and Morphological Considerations in the Differential Utilization of Raw Materials

Different tool classes appear to be correlated with particular raw material varieties. The majority of cores and large bifacial tools 
Table 7.5. Ot1lization of local raw waterials in Lake Fork 11thic debris.

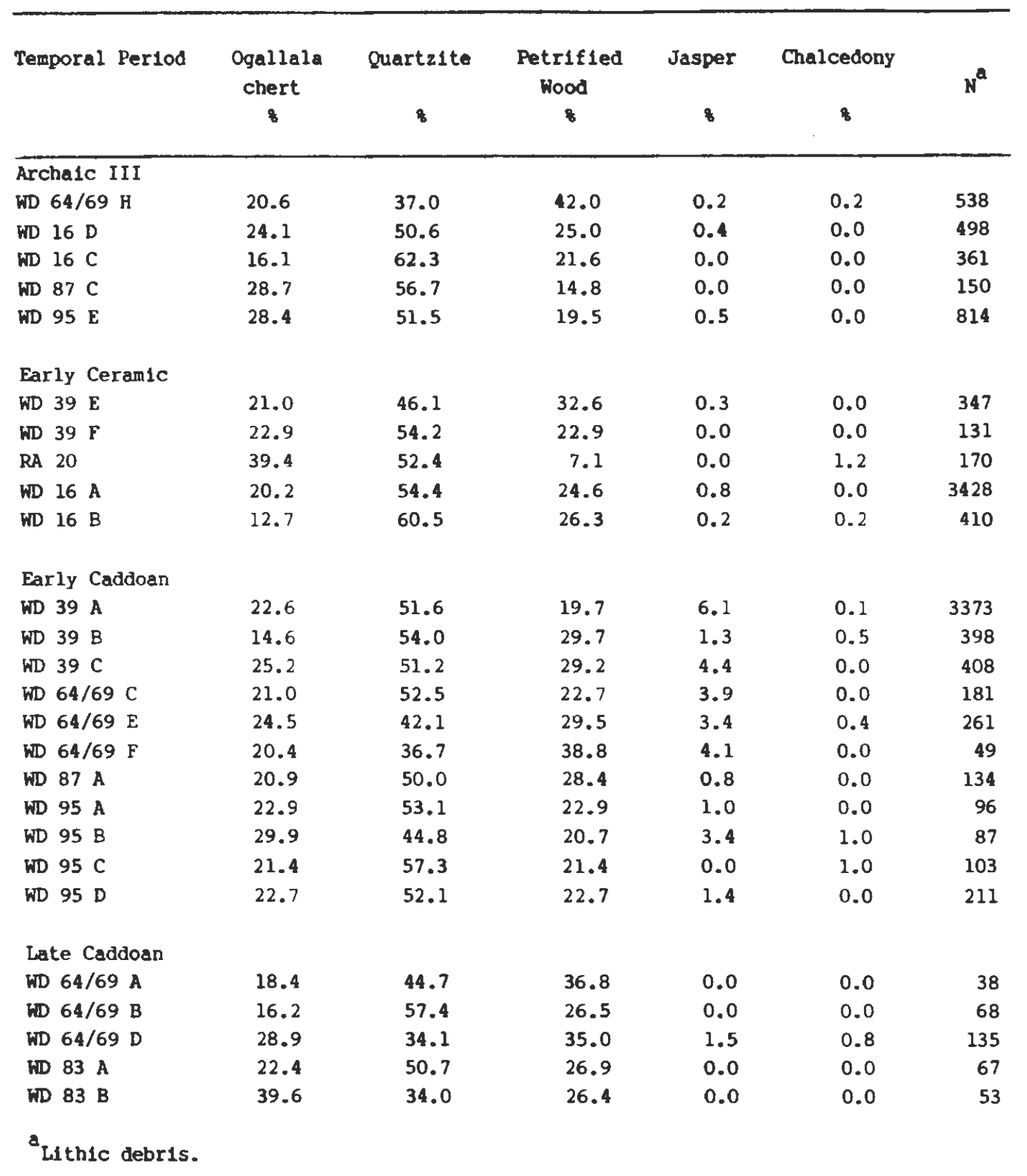

(bifaces, axes, etc.) are manufactured from local coarse-grained cherts, quartzite, and petrified wood, while the tool classes requiring sharp edges were mainly manufactured from fine-grained cherts. The differences in the utilization of raw materials seem to relate to the kind of durability of the cutting edge desired. An edge produced on coarsegrained material is more durable than an edge produced on fine-grained material.

The utilization of nonlocal raw material is such that the majority of tools requiring a sharp cutting edge (retouched pieces, flake tools, projectile points, etc.) are expected to be of this material. Furthermore, the relative scarcity of nonlocal material should result in the maximization of its use through resharpening and/or secondary tool utilization. Tools requiring a more durable edge would be expected to be made of local materials such as quartzite and petrified wood. 
To investigate the correlation of raw material types with particular tasks, each defined tool class was examined in terms of local versus nonlocal raw material. The consideration of raw material differences by tool types is complementary to the functional analyses also carried out as part of the lithic analysis (Bruseth and Perttula 1979:214-263) since the results can be applied to further test the initial inferences about the functional variability in Lake Fork lithic assemblages (e.g., Greiser and Sheets 1979). The mechanisms of resource procurement and the consequent availability of the "most" suitable raw material greatly depends on prevalent patterns of exchange. While some raw materials appear to have been more suitable for particular tasks than others, the predictable availability of various raw materials influenced the ultimate selection of cherts.

\section{Chipped Stone Tool Types}

The patterns of raw material utilization by defined tool types is comparable through all temporal periods in the Lake Fork area. Particular assemblage data are summarized in Table 7.6. Retouched pieces are predominantly nonlocal materials capable of producing a sharp cutting edge (cf. Wright 1980:212). Large projectile points (projectile points and/or hafted cutting tools), on the other hand, were predominantly manufactured from coarse-grained quartzites, Ogallala chert, and petrified wood. Even within the Ceramic phase components, large projectile points were consistently manufactured from local materials.

Table 7.6 The correlation of nonlocal raw materials with tool types.

\begin{tabular}{|c|c|c|c|c|c|}
\hline Tool Types & $\begin{array}{l}\text { Archaic III } \\
\text { WD } 64 / 69 \mathrm{H}\end{array}$ & $\begin{array}{l}\text { Early } \\
\text { Ceramic } \\
\text { WD } 16 \mathrm{~A}\end{array}$ & $\begin{array}{l}\text { Early } \\
\text { Caddoan } \\
\text { WD } 39 \text { A }\end{array}$ & WD $64 / 69 \mathrm{E}$ & $\begin{array}{l}\text { Late } \\
\text { Caddoan } \\
\text { WD } 99 / 100 \\
\end{array}$ \\
\hline Retouched plece & $46.0^{\mathrm{a}}$ & 40.0 & 38.4 & 80.0 & 62.5 \\
\hline B1face & 5.3 & 7.4 & 12.5 & 0.0 & 0.0 \\
\hline Small arrow point & & 55.0 & 49.2 & 92.3 & 40.0 \\
\hline Large dart point & 26.3 & 21.4 & 15.8 & 0.0 & \\
\hline Drill & & 100.0 & 100.0 & & \\
\hline Notch & & 100.0 & & 100.0 & \\
\hline End Scraper & & & 100.0 & & \\
\hline Perforator & & & 75.0 & & \\
\hline Celt & & 100.0 & 100.0 & & 100.0 \\
\hline Axe & & 100.0 & & & \\
\hline Pitted Stone & 0.0 & 0.0 & 0.0 & 0.0 & 0.0 \\
\hline Mano & 0.0 & 0.0 & 0.0 & 0.0 & 0.0 \\
\hline${ }^{a}$ Percentage & & & & & \\
\hline
\end{tabular}

There are no major differences in the utilization of nonlocal raw materials for the manufacture of small projectile points from the Early Ceramic through the Late Caddoan period; however, the frequency of its use is approximately 4 to 8 times as high as for bifaces, and 2 to 3 times as high as for large projectile points (Table 7.6). Bifaces are uniformly manufactured from local raw materials (approx. 758-1008) for all temporal periods. The functional analysis indicated that bifaces were utilized in a variety of ways (tasks), all probably of a generalized nature, and bifaces were probably designed to have a durable working 
edge suitable for multiple functions. The local raw materials are most adequate for this type of edge. Other tool forms such as drills, notches, perforators, and scrapers begin to appear after the Early Ceramic period, and they are almost exclusively made of nonlocal materials.

The dependence on local raw materials for both utilized bifaces and large projectile points, combined with the variety of functions represented by these tools (Bruseth and Perttula 1981:Table, 6-6), argues for a relatively generalized pattern, one not altered even in the Early Caddoan period when the utilization of nonlocal raw materials is at a maximum. Large "projectile points" were designed to be equally useful in both projectile and cutting functions. The choice of raw materials for these forms (i.e., local coarse-grained materials) was thus a compromise to accomodate multiple functions. The specialized nature of small projectile points contrasts with bifaces/large projectile points not only in function but also in the utilization of nonlocal raw materials. The small points from all ceramic components are predominantly nonlocal raw materials. The factors that contribute to the overall stability of the system are more than purely functional considerations, i.e., selection for different edge characteristics.

There is no reason to infer that the criteria for choice of raw material for projectile point manufacture were solely functional. The piercing quality of locally produced projectile points is probably comparable to those made on nonlocal materials, at least judging from the presence of locally made small projectile points throughout all components and temporal periods in Lake Fork and other adjacent areas (Doehner and Larson 1978; Lynott 1975). It could be suggested that nonlocal raw materials were easier to manipulate than local materials. However, the presence of locally manufactured small projectile points of coarse-grained quartzites and petrified woods indicate that this is not necessarily the case.

It may be that when a cobble or blank of nonlocal raw material was secured, the design was to maximize its utilization by manufacturing a number of flakes suitable for use as cutting tools, rather than manufacturing a limited number of large tools. Thus, with limited availability of an exotic raw material, its use is primarily restricted to those tool forms that most efficiently utilize this material, while other tool forms will continue to be manufactured on local materials.

The importance of unretouched and retouched cutting tools in a total tool assemblage has been aptly commented upon by Callahan in his Living Archaeology project:

Aside from hafted knives and celts, our most useful little tool was the so-called "waste" flake. We used biface thinning flakes for stripping bark for our packs and gathering baskets, for processing. cordage for fishline, for cutting meat and wild vegetal goods to size, for skinning and butchering small game, for scraping deer hides, for processing bark strip cordage for our shelter and raft, for carving our bone harpoons and fish hooks, for arrow shaft and foreshaft modification, for bow stave planing and scraping, and for gathering virtually all the sweet flag thatching for our shelter. For those jobs, such flakes were in most cases the only tools used. That is to say, unmodified or slightly modified biface thinning flakes were a primary priority of our camp (1974:7). 
With the advent of small projectile points, multiple tool needs could be satisfied with one blank or cobble; particularly so when the availability of nonlocal raw materials increased during the Early Caddoan period. In summary, it is suggested that the raw material arrays during the different periods in the Lake Fork area reflect functional and maximization considerations in conjunction with increased availabllity of nonlocal materials. Local materials were consistently utilized for large tools such as bifaces and projectile point/hafted cutting tools, while nonlocal materials were utilized for smaller tools with sharper, but less durable, cutting edges. Differences in the presence and availability of nonlocal raw materials through time did not significantly modify this pattern.

Groundstone Tools

Only celts were manufactured of exotic raw materials, primarily from quartzitic sandstone from the Jack Fork Formation in the Ouachita Mountains. The remainder of the groundstone tools were manufactured exclusively from local ferriginous sandstone, hematite, and quartzite (Table 7.6).

The similarity of celts from Early and Late Caddoan components to celt forms at the Sam Kaufman Site (Ferring 1969:89), the lack of spalls indicative of initial manufacturing processes, and the extensive reworking, all argue for the celts entering Lake Fork assemblages in a blank or finished state (see also Wright 1980:226). Type 2 celt forms at Sam Kaufman (the forms found in Lake Fork Reservoir) are not common nor extensively worked, perhaps indicating that the majority of these forms were carried elsewhere, while the more common Type 1 celts at Sam Kaufman were those locally favored and not considered exchangeable goods.

\section{Conclusions}

A tentative model of lithic raw material utilization applicable to the non-Red River watersheds of the Gulf Coastal Plain of the Caddoan Area has been outlined. The model is based on assumptions concerning interareal exchange, hypothesized subsistence and territorial changes through time, and preliminary evidence about the utilization of nonlocal raw materials in lithic assemblages. The lithic raw material data from Lake Fork assemblages were reviewed with regard to the requirements of the model parameters and ancillary functional considerations.

Many factors influence the kind and quantity of stone tools that appear at a given component within any one temporal period. Comparability between assemblages is essential to properly evaluate the changes in lithic raw material utilization through time. Differing emphases on tool maintenance or tool manufacture at components can also skew lithic raw material representation. All Caddoan period components seem, based on flake size (e.g.. Raab et al. 1979) and lack of cores, to have emphasized tool maintenance rather than on-site manufacture. Higher frequencies of cores and petrified wood at Archaic components may indicate slightly different emphases; i.e., different reductive strategies suitable for the hard-to-work silicified woods. Debitage:tool ratios (Table 7.7) are consistent within all temporal periods for both local debitage:tool and nonlocal debitage:tool components. This suggests similar patterns of maintenance and stone 
Table 7.7 Debitage:tool ratios by raw material type.

Local Debitage:Tool

Nonloca1 Debitage: Tool

\begin{tabular}{|c|c|c|}
\hline \multicolumn{3}{|l|}{ Archaic II } \\
\hline WD 19 B II & $29.7: 1$ & $4.3: 1$ \\
\hline \multicolumn{3}{|l|}{ Archaic III } \\
\hline HD $64 / 69 \mathrm{H}$ & $10.6: 1$ & $5.6: 1$ \\
\hline WD $16 \mathrm{D}$ & $25.0: 1$ & $16.4: 1$ \\
\hline WD $95 \mathrm{E}$ & $41.9: 1$ & $58.5: 1$ \\
\hline WD $16 \mathrm{C}$ & $52.3: 1$ & $16: 1$ \\
\hline WD $87 \mathrm{C}$ & $30.0: 1$ & $10: 1$ \\
\hline \multicolumn{3}{|c|}{ Early Ceramic } \\
\hline RA 20 & $26.6: 1$ & $4.9: 1$ \\
\hline WD $39 F$ & $14.5: 1$ & $4.0: 1$ \\
\hline WD $19 \mathrm{BI}$ & $15.4: 1$ & $15.0: 1$ \\
\hline WD $39 \mathrm{D}$ & $24.9: 1$ & $8.3: 1$ \\
\hline WD $16 \mathrm{~B}$ & $82.4: 1$ & $31.5: 1$ \\
\hline WD $16 \mathrm{~A}$ & $24.6: 1$ & $14.7: 1$ \\
\hline \multicolumn{3}{|c|}{ Early Caddoan } \\
\hline WD $39 \mathrm{~A}$ & $39.1: 1$ & $31.2: 1$ \\
\hline WD $39 \mathrm{~B}$ & $44.7: 1$ & $19.8: 1$ \\
\hline WD $39 \mathrm{C}$ & $41.1: 1$ & $21.5: 1$ \\
\hline WD $64 / 69 \mathrm{C}$ & $31.3: 1$ & $24.5: 1$ \\
\hline WD $64 / 69 \mathrm{E}$ & $29.4: \frac{1}{7}$ & $9.5: 1$ \\
\hline WD $64 / 69 \mathrm{~F}$ & $n / a^{a}$ & $7.3: 1$ \\
\hline WD $87 \mathrm{~A}$ & $10.3 \div 1$ & $4.2=1$ \\
\hline WD $95 \mathrm{~A}$ & $19.6: 1$ & $14.5: \frac{1}{2}$ \\
\hline WD $95 \mathrm{~B}$ & $44.0: 1$ & $\mathrm{n} / \mathrm{a}^{\bar{a}}$ \\
\hline WD $95 \mathrm{C}$ & $34.7: 1$ & $8.0: 1$ \\
\hline WD $95 \mathrm{D}$ & $107.5: 1$ & $19.3: 1$ \\
\hline WD 50 & $17.7: 1$ & $10: 1$ \\
\hline \multicolumn{3}{|c|}{ Late Caddoan } \\
\hline WD $64 / 69 \AA$ & $38: 1$ & $6: 1$ \\
\hline WD $64 / 69 \mathrm{~B}$ & $35: 1$ & $\mathrm{n} / \mathrm{a}$ \\
\hline WD $64 / 69 \mathrm{D}$ & $27.2: 1$ & $7.2: 1$ \\
\hline WD $83 \mathrm{~A}$ & $33.5: 1$ & $4.3: 1$ \\
\hline WD $83 \mathrm{~B}$ & $13.3: 1$ & $8.1: 1$ \\
\hline WD $99 / 100$ & $11.9: 1$ & $10.8: 1$ \\
\hline
\end{tabular}

tool working at all sites through most, if not all, temporal periods for both nonlocal and local materials. In addition, the consistently low debitage: tool ratios of nonlocal raw materials, when compared to local materials, indicate that nonlocal raw material arrived at sites in blank or finished form and was subjected to little additional alteration or recycling. Further research on the problem of lithic raw material utilization changes needs to take all these considerations into account, particularly comparability, adequate temporal control, and small sample sizes. Our research procedure could certainly have benefited from better control over these parameters. 
The study of procurement patterns and modes of transportation of local and nonlocal materials has deliberately not been stressed in the Lake Fork study. No clear differentiation between direct and indirect procurement processes (cf. Klinger and Mathis 1978:61) is known because of the many intervening and unknown factors that affect formation of the archaeological record. The process of reduction conducted at outcrop locales, the possibility of finished forms or preforms being introduced into sites, and the differing manufacturing processes occurring at sites due to functional reasons (Raab et al. 1979) all need to be considered before probable procurement methods can be specified.

Only one outcrop locale of local material is known in the Upper Sabine River Basin, approximately $40 \mathrm{~km}$ south of Lake Fork Creek: there are probably many others that have gone unnoticed. Malone states that

The coarse-grained, sugarlike quartzite occurs in outcrop areas in the form of large boulders. These cover 3 or 4 acres in several places near the center of the reservoir (Mineola Reservoir) areas. Site $41 \mathrm{VN} 39$ shows signs of removal of considerable amounts of material. Partially decorticated cores, as well as numerous flakes, were present (1972:32).

It is unclear how applicable the proposed lithic raw material utilization model is to East Texas. High-quality, fine grained silicates are common only at the northern end of the area, especially in the gravels of the Red River and on its terraces. Stream valleys to the south and west of the Red River, however, are primarily within the area of the Uvalde gravels.

Not only are Uvalde Gravels dispersed throughout upland gravel deposits and Pleistocene terrace remnants, but drainage systems cutting across the area carry this reworked material as river gravels. It is not known how far east this sheet wash material was carried during the Pliocene and Early Pleistocene. Menzer and Slaughter (1971:220) suggest the border was possibly the Mississippi Embayment. Gravel deposits in western Louisiana are not comparable in composition to Uvalde Gravels, being made up of 908 chert pebbles that come primarily from Paleozoic outcrops in the Ouachita Mountains (Woodward and Gueno 1941:37). Tertiary uplands from Natchitoches to Shreveport, Louisiana, are barren of gravel. Quite possibly then, the Sabine Uplift of eastern Texas (Sellards et al. 1932), which partly separates the East Texas embayment from the Mississippi Embayment, provided the limiting factor to the eastward spread of Uvalde Gravels, except for material later carried as river gravels. This area, then, is suspected to be the area of primary relevance for further testing and revising of the model.

The prehistoric inhabitants of Lake Fork utilized varying quantities of nonlocal high-quality cherts mainly available within a $100 \mathrm{~km}$ radius (Table 7.8). Nearby areas such as Lake Lavon on the East Fork of the Trinity River (Lynott 1975), Cooper Lake on the Upper Sulphur (Doehner. Peter and Skinner 1978), Cedar Creek Lake on Cedar Creek (Story 1965), and areas on the upper and middle Sabine (Duffield 1959; Malone 1972:34) utilized approximately 908-988 local Ogallala chert, quartzite, and petrified wood. The high quality cherts, available only 50-100 km away in Red River Gravels, are noticeably absent during the Early Caddoan (or Neo-American) period. Surrounding areas of high 
Table 7.8. Presence of nonlocal rav material types by temporal periods in the Lake Fork assemblages.

\begin{tabular}{|c|c|c|c|c|c|}
\hline Types & $\begin{array}{c}\text { Archaic } \\
\text { II }\end{array}$ & $\begin{array}{c}\text { Late } \\
\text { Archaic }\end{array}$ & $\begin{array}{c}\text { Early } \\
\text { Ceramic }\end{array}$ & $\begin{array}{r}\text { Early } \\
\text { Caddoan }\end{array}$ & $\begin{array}{l}\text { Late } \\
\text { Caddoen }\end{array}$ \\
\hline Novaculite & $x$ & $\mathrm{x}$ & $\mathbf{x}$ & $x$ & $\mathrm{x}$ \\
\hline Edwards & $\mathrm{x}$ & $x$ & $\mathbf{x}$ & $\mathbf{x}$ & $\mathbf{x}$ \\
\hline Keokuk & & $\mathrm{x}$ & & $\mathrm{x}$ & \\
\hline Woodford & & & $\mathbf{x}$ & $x$ & $\mathrm{x}$ \\
\hline B1g Fork black & & $\mathrm{x}$ & $\mathbf{x}$ & $\mathrm{x}$ & \\
\hline B1g Fork green & & $\mathrm{x}$ & $x$ & $x$ & $\mathbf{x}$ \\
\hline \multicolumn{6}{|l|}{ Weathered } \\
\hline Hetamorphic & & & $\mathrm{x}$ & $\mathrm{x}$ & \\
\hline \multicolumn{6}{|l|}{ Quartzit1c } \\
\hline Sandstone & & $\mathrm{x}$ & $\mathrm{x}$ & $x$ & $x$ \\
\hline \multicolumn{6}{|l|}{ Honey-colored } \\
\hline Chert & $x$ & $\mathrm{x}$ & $x$ & $x$ & $\mathrm{x}$ \\
\hline Gray chert & $x$ & $x$ & $x$ & $x$ & $x$ \\
\hline Quartz & & & & $x$ & \\
\hline Black chert & $\mathrm{x}$ & $\mathrm{x}$ & $\mathrm{x}$ & $\mathrm{x}$ & $x$ \\
\hline Frisco chert & $x$ & $\mathrm{x}$ & & $\mathrm{x}$ & $x$ \\
\hline
\end{tabular}

utilization of nonlocal materials have been described (Briggs and Malone 1970:27-29; Mallouf 1976:45) that pertain to this temporal period.

Occupants within the Blackland Prairie during the A.D. 800-1300 period thus had limited interaction with prehistoric Caddoan and Austin/Toyah phase cultural groups who inhabited areas with high-quality cherts. Evidence of interaction (the presence of sherds) is more common, but in no case abundant. In any event, what interaction there was probably ended by approximately A.D. 1000 (M. Lynott, personal communication). A tentative "boundary" between Caddoan groups and the occupants of the Blackland Prairie can be suggested from this evidence. High-quality cherts were distributed from the Red River area and Central Texas to the Caddoan groups farther south and east, such as Lake Fork, bypassing the intermediate and adjacent groups.

The lowland areas of eastern Arkansas have been the focus of research efforts dealing with the procurement and utilization of nonlocal lithic raw materials (House 1977: Klinger and Mathis 1978:59-63). Coming to grips with basic questions, such as the function of exchange in adaptive strategies, i.e.. why exchange occurs or why there were different emphases in the utilization of raw materials during certain periods, are only some of the research problems that can be dealt with in the study of lithic raw materials (House 1977:375-376).

Raw material studies comparable to Webb's (1977:53) for the Poverty Point complex will be necessary within this region of the Southeast before some of the apparently shifting patterns in resource procurement are clarified. Brain's (1976) discussion of the varying emphasis on social and ceremonial activities over time in the Southeast is pertinent to any evaluation of what factors contributed to cultural decisions concerning lithic raw material utilization and exchange in general. The exchange network for Poverty Point, for example, is much more expanded than the Caddoan network discussed in this paper. Lithic materials from Missouri, Illinois, Ohio, Tennessee, and other distant sources, such as the Great Lakes, seem to be common at the Poverty Point Site (Webb 1977: Fig. 28). However, more recent study 
of the Poverty Point lithic material (S. Bass 1981) suggests that the variety of lithic raw materials present at the site results not from the procurement of nonlocal materials but from the wide variety of lithics found in local Pleistocene gravels. No comprehensive study of nonlocal materials from the primary Caddoan centers, such as Spiro, Battle, or Davis, have been conducted, so this picture may be illusionary. Spiro appears to have a high variability of raw materials from sources such as Missouri and Tennessee and may be comparable to Poverty Point when fully studied (cf. Brown 1976). Nevertheless, the implications of this behavior in studies of exchange and adaptation will remain unclear until such analysis is begun. Hopefully, this study will contribute to further and more detailed studies, which, by taking a perspective that relates processes of subsistence, settlement, lithic assemblages, and changes in adaptation, may eventually lead to a more refined and comprehensive understanding of the archaeological record in the Caddoan area.

\section{Acknowledgments}

I would like to thank James E. Bruseth for his comments and advice on the lithic analysis of the Lake Fork material, and the initial opportunity to work on the Lake Fork project. Dr. S. Alan Skinner served as Principal Investigator for the project. Without the cooperation and assistance of Larry Banks and Kate Huckabay in the sorting and classification of lithic raw material types, this study would not have been possible. I would also like to thank Kathy Boswell for typing this paper. Any errors of interpretation are a result of this author's shortcomings. 


\title{
The Goldsmith Site (41WD208): Investigations of the Titus Phase in the Upper Sabine River Basin, Wood County, Texas
}

\author{
Timothy K. Perttula, Bob D. Skiles, and Bonnie C. Yates
}

\begin{abstract}
Salvage and test excavations at the Goldsmith site (4 IWD208), on Dry Creek in the Upper Sabine Basin of East Texas, yielded significant information on a Late Caddoan Titus phase house site with an associated trash midden and cemetery. On the basis of similarities in material culture and stylistic ceramic motifs, the site may be but one in a cluster of comparable and contemporaneous sites nearby that are considered part of the Three Basins subcluster. Single homestead/farmsteads are the most common type of Late Caddoan setulements in the Upper Sabine Basin. However, the scrutiny of professional and avocational archeologists has been concentrated on the cemeteries associated with the homesteads and has overlooked sites such as Goldsmith, which also hold consider able potential for the investigation of Late Caddoan subsistence systems, local and regional settlement patterns, and changes in sociopolitical organization.
\end{abstract}

\section{INTRODUCTION}

The Goldsmith site, a Late Caddoan Titus phase hamlet in the Upper Sabine River Basin, Wood County, Texas, was discovered in the fall of 1984 when a service road was cut through the area to a well pad in the Quitman Oil Field. During construction of the well platform, which had been built up from fill dirt bulldozed from a deep road cut, disturbed archeological materials were found, and a local collector reported that large fragments of ceramic vessels had been found on the surface.

On close examination of the cut, the collector found a pottery vessel in situ in the bank. Subsequent digging by the collector exposed nine more pottery vessels and two greenstone celts that were in an ENE-WSW-oriented burial pit. As is typical for Caddoan burials excavated in the highly acidic, sandy soils of the Piney Woods, no traces of human bone were preserved in the burial pit. Other burials or clusters of pottery vessels were removed in random potholing by unknown individuals who dug in an area about a meter north of the first burial; these discoveries stimulated a spate of pothunting at the site. Within a few days, a 10-meter-wide area around the first burial and a nearby midden had been pockmarked by dozens of potholes.

Skiles made a reconnaissance of the site more than a month after the initial disturbances in order to assess the condition and character of the archeological

Friends of Northeast Texas Archaeology, Special Publication No. 1 (1995) 
deposits. At that time, it was noted that the roadcut had bisected a small, dense midden deposit about 30 meters to the southeast of the area where the ceramic vessels and burials had been disturbed (Figures 1, 2). Many potholes had been dug along the edges of the midden, but, because of a large pile of trees that had been put there when the roadway was cleared, most of the midden was protected by its inaccessibility.

Pothunting apparently subsided after the initial discoveries. However, in the interest of preserving the midden and remaining cemetery areas, the owner of the property agreed to try to curb further vandalism by installing a locked gate and No Trespassing signs on the road to the site. Unfortunately, though, within the month many additional potholes had been dug in the cemetery area and the midden, and it became clear that the site could not be adequately protected or preserved by these measures. Considering the likelihood that the site would be destroyed by uncontrolled pothunting, due in part to its ready accessibility, it was decided to recover as much data on the site as was possible in lieu of preservation. These limited investigations, in which Dr. James Bruseth, then Director of the Archaeology Research Program at Southern Methodist University, played an integral role by devising a field strategy and encouraging the work, were carried out in January and September 1985, by Skiles and Perttula, with volunteer assistance from Mr. Robert Turbeville and Ms. Peggy Trachte.

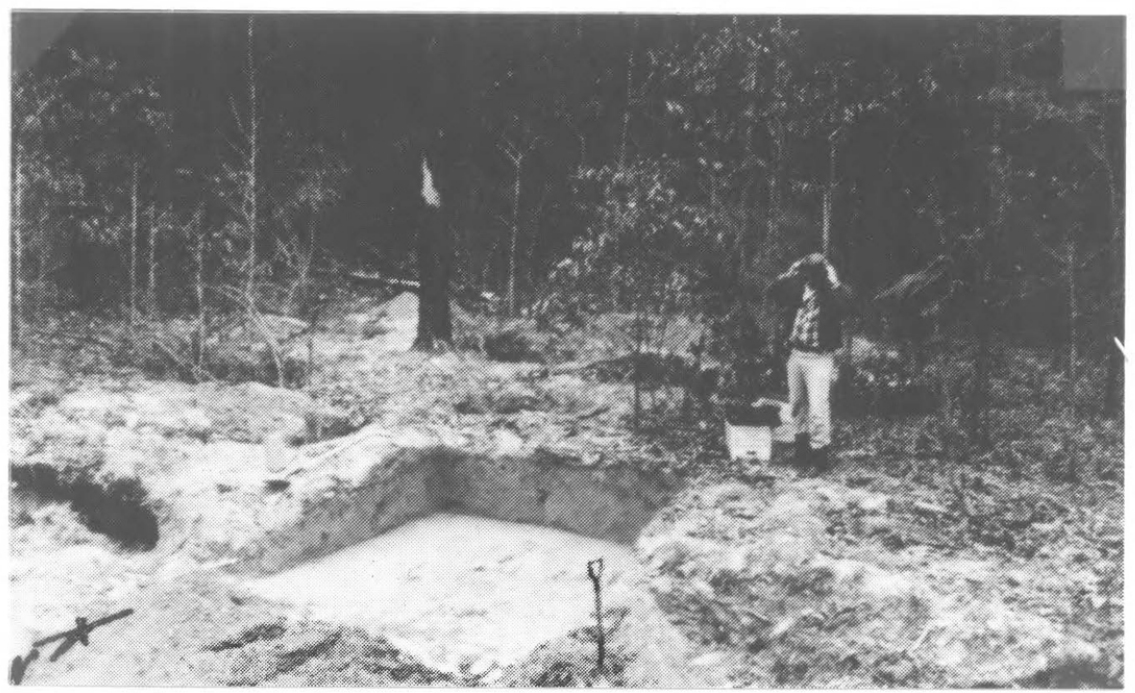

Figure 1. The cemetery area at the Goldsmith Site (41WD208). 


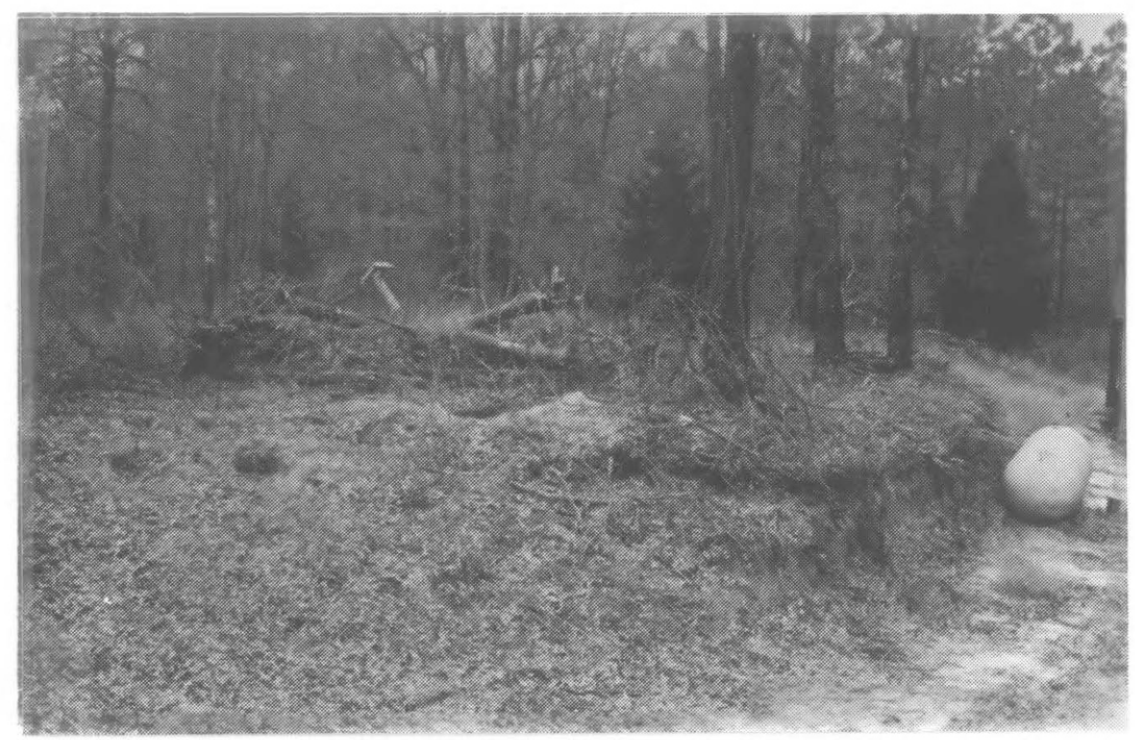

Figure 2. The midden area at the Goldsmith Site.

\section{NATURAL SETTING}

The Goldsmith site is on Dry Creek, a permanent tributary of Lake Fork Creek, in the westem part of the Gulf Coastal Plain of Texas. The floodplain of Lake Fork Creek is about $7 \mathrm{~km}$ downstream from the site, and it is $20 \mathrm{~km}$ further from the floodplain to the confluence of Lake Fork Creek with the Sabine River in southcentral Wood County. The headwaters of Dry Creek and its tributaries are 5 to 10 $\mathrm{km}$ to the north-northwest of Goldsmith; the creek flows generally southward from Coke, Texas to its confluence with Lake Fork Creek due south of the town of Quitman, Texas (Figure 3).

Three major biotic communities have been recognized on the western part of the Gulf Coastal Plain in East Texas: the Oak-Hickory or Post Oak Savannah, the Blackland Prairie, and the Oak-Hickory-Pine forest or Piney Woods (Blair 1950). The Post Oak Savannah is a narrow southwest-northeast-trending belt of woodland that appears to mark a natural transition zone between the more xeric (drier) Blackland Prairie to the west and the Oak-Hickory-Pine Forest to the east (Küchler 1964). The Goldsmith site is within the modern boundary of the Piney Woods.

The Piney Woods consist of medium tall to tall deciduous trees with shortleaf and loblolly pines; they are typically on upland fine sandy loam soils with adequate moisture storage. In some cases, the presence of pine represents a subclimax vegetational association or fire disclimax (Gould 1969). Poorly drained soils in the biotic community may create a favorable habitat for prairie, dominated by big bluestem, little bluestem, switchgrass, and Indiangrass (Marietta and Nixon 1984). 


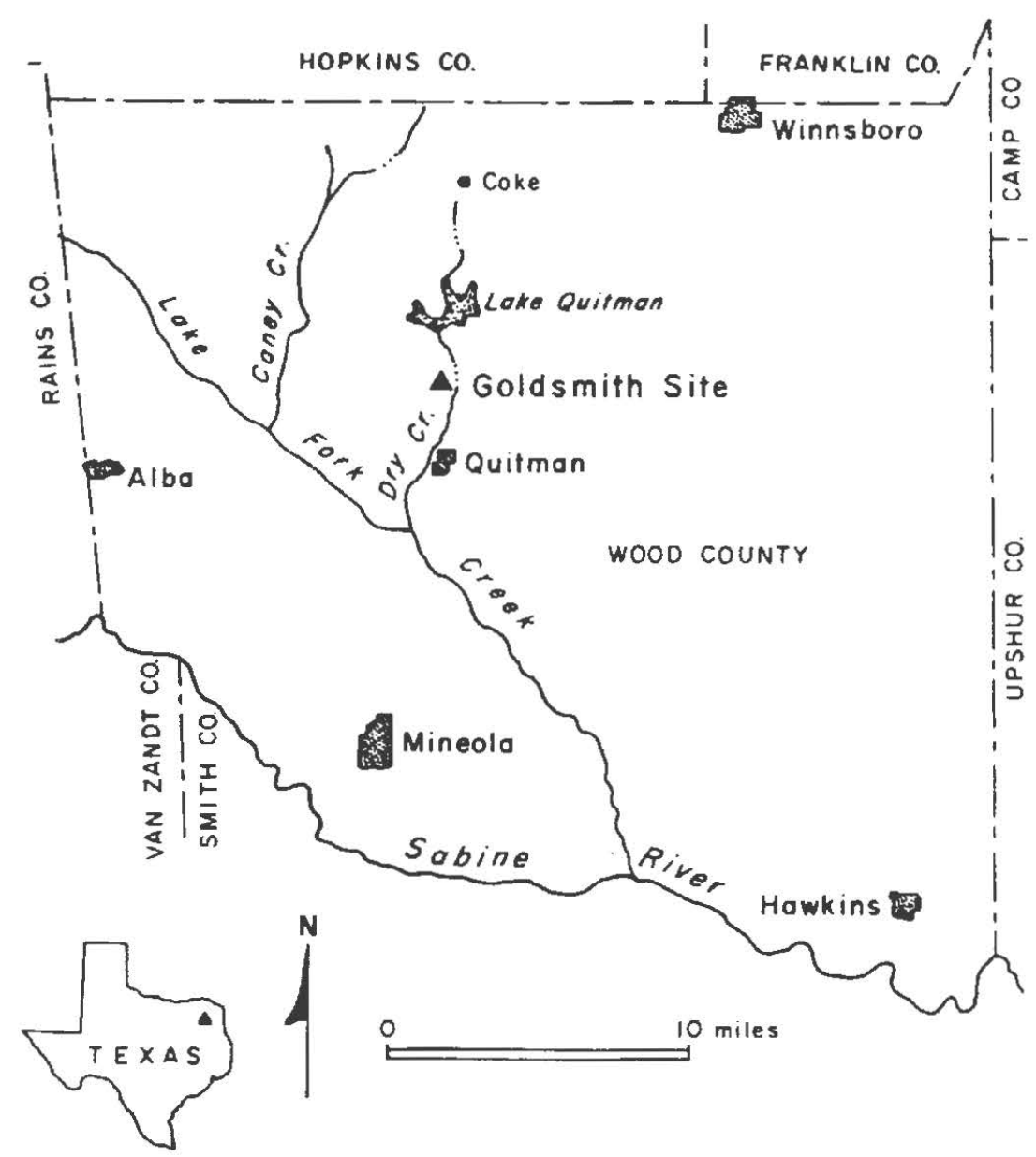

Figure 3. Map of Wood County, Texas, showing the location of the Goldsmith site.

The Sabine River and its tributary floodplains form bottomland communities of hardwood and swamp forests. Basic components of the floodplain hardwood forests are sweetgum, water oak, overcup oak, willow oak, and cottonwood. Other trees commonly found in the alluvial floodplain are green ash, black willow, Amcrican elm, river birch, and American hombeam (U.S. Army Corps of Engineers 1975). Swamp forests on the floodplain have overstories of black tupelo, elm, overcup oak, and grcen ash. These areas are inundated, except during periods of prolonged drought. This swamp forest is most extensive in the floodplain of the Sabine River, but patches of it also grow on the very wet tributary creekbottoms (e.g., Nixon et al. 1983). 
The East Texas part of the western Gulf Coastal Plain is within the Austroriparian province defined by Blair (1950). Included in the 47 species of mammals, 39 species of reptiles, and 17 species of amphibians are many that reach the limits of their ranges in the southeastern United States. Exploitable species have been generally summarized by Thurmond (1981:Table 2), Bruseth and others (1977:Tables 4, 5), and, for the Big Cypress and Upper Sabine basins, by Espey, Huston and Associates, Inc. (1984).

The climate of the Upper Sabine River Basin is humid, with average winter temperatures of $8^{\circ} \mathrm{C}\left(47^{\circ} \mathrm{F}\right)$ and summer temperatures of $28^{\circ} \mathrm{C}\left(83^{\circ} \mathrm{F}\right)$; droughts are not uncommon. The first freeze in winter usually comes between mid-November and December 1, and the last freeze, in mid-March (Arbingast et al. 1973:19). Mean annual precipitation varies from about 115 to $125 \mathrm{~mm}$ in the Upper Sabine Basin (Texas Almanac 1986). Periods of maximum rainfall comc in the spring and fall seasons.

East Texas paleoenvironmental and climatic conditions are poorly known, and only limited evidence of past environments has been acquired that is pertinent to reconstructing the Late Holocene (2000-200 years B.P.) environmental setting at the Goldsmith site (e.g., Bryant and Holloway 1985). Preliminary analyses of Late Holocene pollen samples suggest a dry-moist-dry episodic pattern in the Late Holocene comparable to the Northeast Oklahoma data from the Cross Timbers, Osage Savannah, and Cherokee Prairie districts (Hall 1982; Reid and Artz 1984). Pine, in particular, becomes one of the major constituents of the pollen record at Ferndale Bog in Southeast Oklahoma about 1000 B.P., invading the area at about 1800 B.P. (Albert 1981). Pollen records from the Buck Creek Marsh in the Big Sandy Creek basin of Wood County suggest that pine invaded the valley between 1810 and 1130 B.P. and was the dominant overstory species by about A.D. 500 (Holloway 1987).

Dendroclimatic reconstructions are more specific than pollen records in determining proxy climatic data from the last 500 years and have the potential to be extended to the period between 1,000 and 5,000 years ago (Stahle, Cook, and White 1985). Drought reconstructions using annual tree ring chronologies from old-growth baldcypress indicate that there were many wet and dry spells comparable to twentieth century events between about A.D. 1500 and 1700, the estimated range of time when the Goldsmith site was occupied. In particular, droughts of more than 10 years have been estimated around A.D. 1555, 1570, 1595 , and 1670, separated by wetter periods around 1540,1600,1620, and 1665 (Stahle, Cleaveland and Hehr 1985:Figure 3b). The period between A.D. 1549 and 1577 has been suggested as representing the worst June drought in the past 450 years (Stahle, Cleaveland and Hehr 1985:532). The variation and intensity of climatic fluctuations is of singular importance to the Late Caddoan inhabitants of the Goldsmith site because of their presumed dependence upon maize agriculture as a subsistence base (Perttula et al. 1983:96).

The Goldsmith site is on the edge of an upland landform overlooking the Dry Creek floodplain. A relict channel of Dry Creek, called Blue Lake by local 
residents, runs along the base of the steep upland slope about 100 meters southeast of the site. Blue Lake is a permanent water source that has never completely evaporated even in the hottest and driest summers (H. B. Goldsmith, personal communication).

\section{PREVIOUS RESEARCH AND CULTURAL SETTING}

Archeological research in the Caddoan area, of which the Upper Sabine Basin is a part, has a lengthy history that is impractical to summarize here (see Story 1978; Webb 1978). The reader is referred to Pertula et al. (1986:35-59) for an overview of the history of previous archcological research investigations in the Upper Sabinc River Basin.

In the immediate vicinity of the Goldsmith site, the University of Tcxas conducted investigations between 1930 and 1934, led by A. T. Jackson, M. M. Reese, and A. M. Wilson. The fieldwork concentrated primarily around Quitman in the Dry Creck and Lake Fork Creek basins (Reese 1931; Wilson and Jackson 1930). Eighty-two sites were identified, 12 of which were the subject of burial excavations and midden and structural mound trenching (Table 1). Several of the sites, particularly J. H. Reese (41WD2) and L. L. Winterbauer (41WD6), closely resemble Goldsmith in ceramic assemblages and community/settement patterning, and all three arc now recognized as generally contemporaneous Titus phase occupations. What was evident even in research sponsored by the University of Texas was the concentration of archeological sites in the Dry Crcek-Little Dry Creek basins, a situation that has not been altered since in the years of archeological research conducted in Wood County.

Not until the 1950s did Late Caddoan settements in the area around Quitman receive renewed attention. In 1959 Rober Turbeville, an avocational archeologist in Mincola, Texas, excavated 15 burials from a Titus phase ccmctcry at 41 WD19 on Dry Creek, $1.2 \mathrm{~km}$ west-southwest of Goldsmith. This led to further work by Turbeville in Wood County at 41WD44 and 41WD206, Titus phase middens and cemeteries on Dry and Muddy creeks, 0.6 and $2.5 \mathrm{~km}$ north and northeast of Goldsmith, respectively (Figure 4). This work has provided significant information on Late Caddoan settlement patterns in the Upper Sabine River Basin (Skiles et al. 1980).

In 1975, Southern Methodist University's Archacology Research Program began fieldwork in the proposed Lake Fork Rescrvoir on Lake Fork Creek and tributaries in Wood, Rains, and Hopkins countics, about 25 to $40 \mathrm{~km}$ from Goldsmith. Several of the sites chosen for excavation in 1976, 1978, and 1979 had Late Caddoan components, including the Glen (41WD524), Gilbreath (4 1WD538), Killebrew (41WD495), Sandhill (4IWD108), and Spoonbill (41WD109) sites (Bruseth et al. 1977:127-138; Bruseth and Pertula 1980, 1981).

Sites of this period were classified as components of the Forest Hill phasc, a local manifestation of the Titus phase in the Caney Creek drainage system (Bruseth and Perttula 1981:142). The only absolute date obtained on a Forest Hill phase 
Table 1. Excavations of Titus Phase Sites in Wood County, Texas by The University of Texas, 1930 to 1934

\begin{tabular}{|c|c|c|c|}
\hline Location & Site & Features & $\begin{array}{c}\text { Estimated Period } \\
\text { of Occupation }\end{array}$ \\
\hline Little Dry Cr. & J. H. Reese (41WD2) & $\begin{array}{l}\text { Trash midden, } \\
3 \text { burials }\end{array}$ & $\begin{array}{l}\text { Late Caddoan, } \\
\text { Titus phase }\end{array}$ \\
\hline Little Dry Cr. & Earl Jones (41WD3) & Midden mound & $\begin{array}{l}\text { Late Caddoan, } \\
\text { Titus phase }\end{array}$ \\
\hline Lake Fork Cr. & $\begin{array}{l}\text { L. L. Winterbauer } \\
\text { (41WD6) }\end{array}$ & $\begin{array}{l}\text { Trash midden, } \\
\text { Dog burials }\end{array}$ & $\begin{array}{l}\text { Late Caddoan, } \\
\text { Titus phase }\end{array}$ \\
\hline Dry Creek & $\begin{array}{l}\text { A. N. Vickery } \\
\text { (41WD11) }\end{array}$ & Mound & Uncertain \\
\hline Little Dry Cr. & M. E. Day (41WD10) & $\begin{array}{l}\text { Trash midden, } \\
\text { Dog burials }\end{array}$ & $\begin{array}{l}\text { Late Caddoan, } \\
\text { Titus phase }\end{array}$ \\
\hline Brushy Creek & $\begin{array}{l}\text { Minnie Garrison } \\
\text { (41WD16) }\end{array}$ & $\begin{array}{l}\text { Trash midden, } \\
\text { Mound }\end{array}$ & $\begin{array}{l}\text { Early Caddoan } \\
\text { and Late Caddoan, } \\
\text { Titus phase }\end{array}$ \\
\hline
\end{tabular}

setulement is a radiocarbon date of A.D. $1470 \pm 80$ (TX-3473, uncorrected) (J. Bruseth, personal communication) from the nearby Steck site (41WD529) midden.

As an adjunct to the fieldwork in Lake Fork Reservoir, several sites in the Lake Fork Creek Basin outside the project area have been investigated by Southem Methodist University. The Steck (41WD529), Burks (41WD52), and Pine Tree (41WD51) sites have well-preserved Late Caddoan habitation features and both faunal and floral remains that have provided useful comparative information for understanding the Late Caddoan archeological record in the Upper Sabine River Basin (Hockensmith 1977; Pertula et al. n.d.).

\section{INVESTIGATION OF THE CEMETERY AREA}

We decided to concentrate our work at the Goldsmith site first on the cemetery area (Figure 5), because most of the surreptitious digging had been done there, and more vandalism was anticipated. The midden was at least partially protected by the trees that were piled upon it.

We probed the cemetery area systematically on a closely spaced grid before any excavating, in order to locate any remaining burials and to plan future work. Pothunters were so active that it was not deemed advisable to leave burials partly excavated, and, since the amount of work planned had to be limited in accordance with our resources, a stainless steel "whip antenna" about 2 meters long was used to probe randomly in the areas directly adjacent to the first burial 


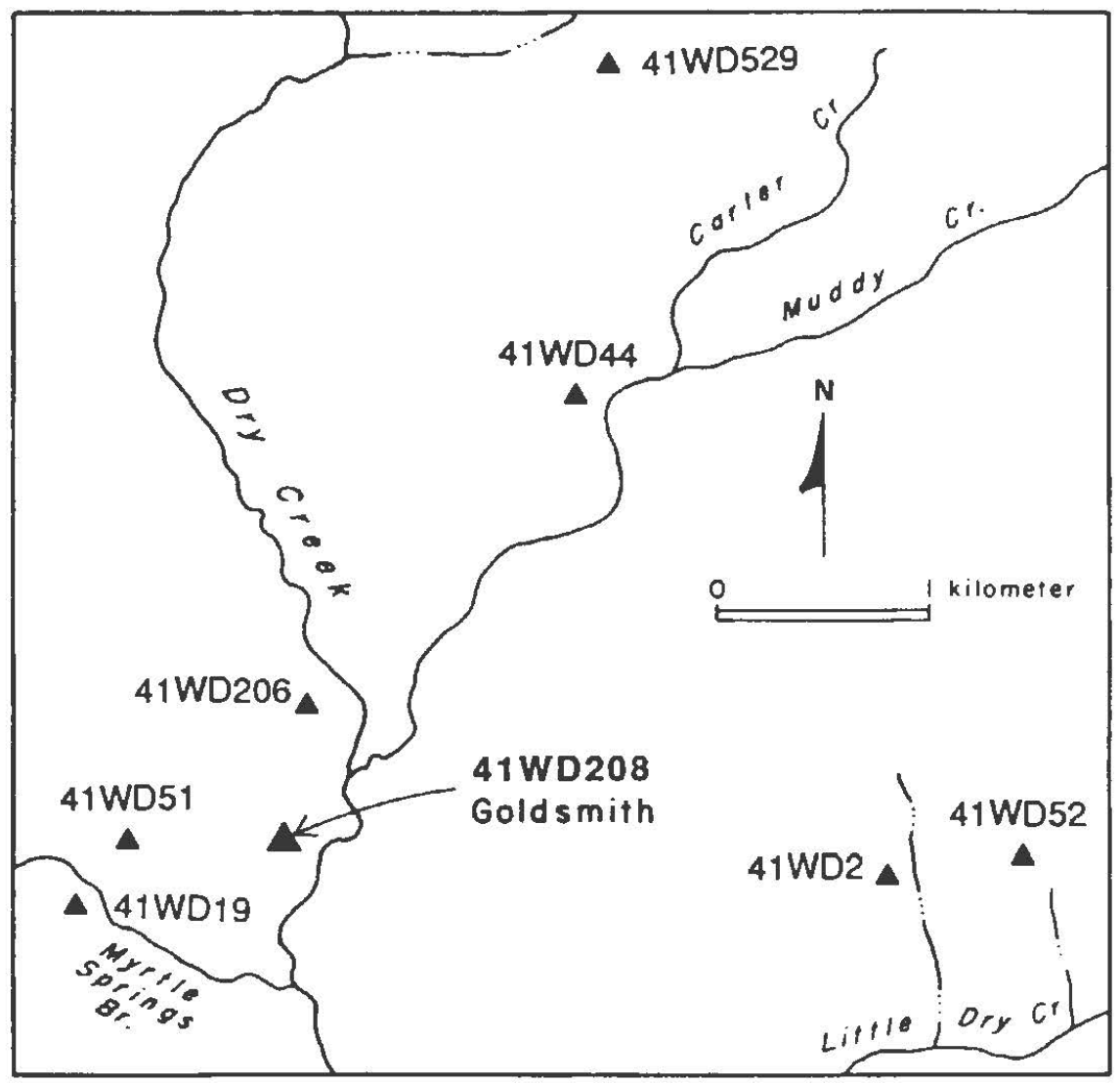

Figure 4. Map of the Dry Creek Basin showing the location of the Goldsmith and other Late Caddoan Titus phase sites.

removed by the collector. This was simply a test to ascertain the suitability of the soil for probing, but within 15 minutes a ceramic vessel was detected about 2 meters northeast of the first burial removed by the collector. A shovel test about $30 \mathrm{~cm}$ in diameter was excavated to a depth of about 1 meter to confirm the existence of the vesscl. Further concentrated probing revealed a subsurface declivity in the clayey sand B-horizon that was a pit feature oriented generally east-west with several other vessels in it. In this area the A-horizon is a tan sand about $80 \mathrm{~cm}$ thick, and the underlying B-horizon subsoil is a mottled yellow clayey sand.

A 2.40-by-2.40-meter unit was centercd over the burial pit and pottery vessels of Burial No. 1 (Figure 6). After removing pothole backdirt piles from the surface, the unit was excavated by shovel skimming in about 2.5 -cm-thick levels. No pit outline was detected in the light tan, coarse loamy sand A-horizon until just above the B-horizon at about $78 \mathrm{~cm}$ below the surface. The upper parts of several vessels 


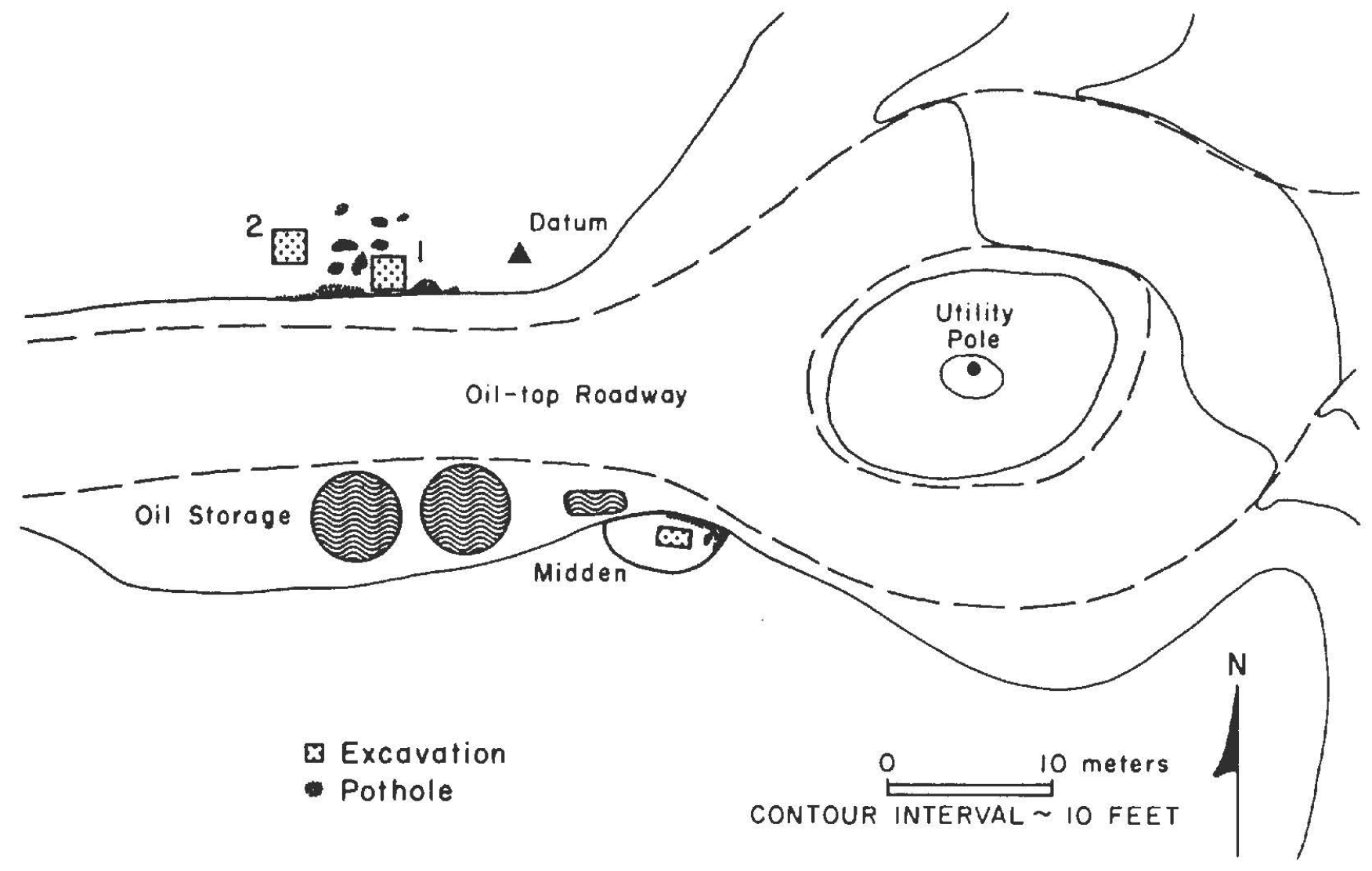

Figure 5. Topographic sketch map of the Goldsmith site. 


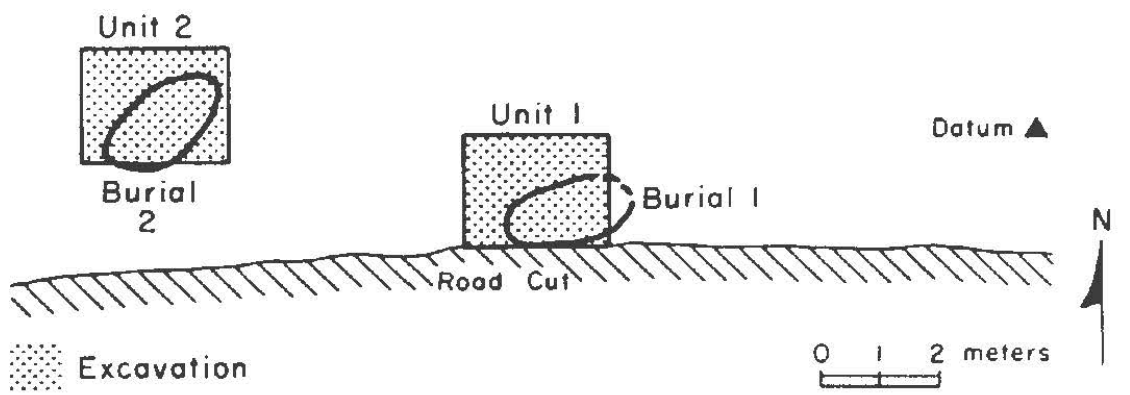

Figure 6. Plan of excavations in the cemetery area.

wcre also reached at this level. The bottom of the burial pit extended $35 \mathrm{~cm}$ into the B-horizon subsoil (Figure 7).

The burial pit, which measures 1.85 by 1.00 meters, contained seven ceramic vessels distributed over the chest area and along each side of the individual (Figurc 8). No traces of bone were noted, but on the basis of several studies of Late Caddoan Titus phase mortuary patterning (Thurmond 1981; Turner 1978; Bell 1981) it was assumed that the individual was placed in extended, supine position and oricnted with the feet to the west. With the burial were seven vessels: one Harleton Appliquc jar (Vessel 1), four Ripley Engraved carinated bowls (Vessels 2-4, 6), one Nash Neck-Banded jar (Vessel 5), and a single Wilder Engraved bottle (Vessel 7). A large part of Vessel 4 had been freshly broken and was missing. Several recently broken sherds from a large red-slipped Ripley Engraved carinated bowl were underneath the remaining fragments of Vessel 4. This comer of the burial pit apparently had been recently disturbed, although the nature of the disturbance could not be determincd.

After Burial No. 2, about 5 meters west-northwest of Burial No. 1 (see Figure 6), was located, a 2-by-2-meter unit was laid out over the burial pit. No burial pit outline could be detected until, at $70 \mathrm{~cm}$ below the present ground surface, the B-horizon, into which the burial extended about $10 \mathrm{~cm}$, was reached. The burial pit measured 2.25 by 1.15 meters, and was oriented NE-SW (Figure 9). Again, no bone was preserved in the pit, but it is assumed that the head was oriented roughly toward the northeast in conformance with Burial No. 1 and all known adult Titus phase burials in the Dry Creck drainage.

Grave goods were distributed irregularly throughout the Burial No. 2 pit below presumed shoulder level. Two greenstone celts were in the pelvic area, and a group of four arrowpoints (three Maud and one Bassett type), and an engraved ceramic elbow pipe with a flaring bowl, were between the legs at about the knee level (sec Figure 9). Two roughly shaped tools of locally available ferruginous sandstonc were at the feet; these may have been used as digging tools in the preparation of the burial pit. Another group of four Maud arrowpoints was placed along the left (east) cdgc of the burial pit. A possible Talco arrowpoint was recovered on the B-horizon 


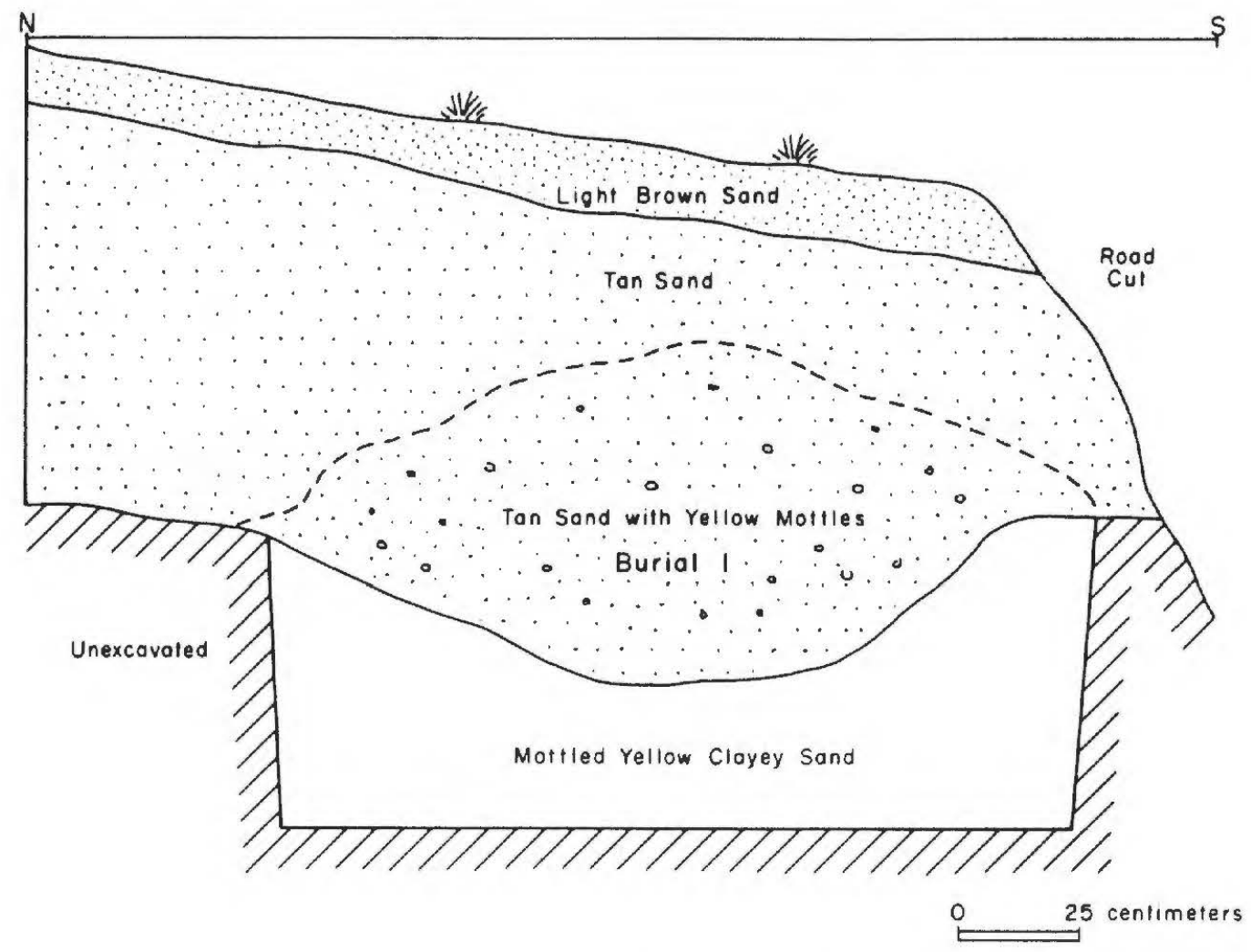

Figure 7. Profile of the west wall of Unit 1 showing the motled fill in the Burial 1 pit. 


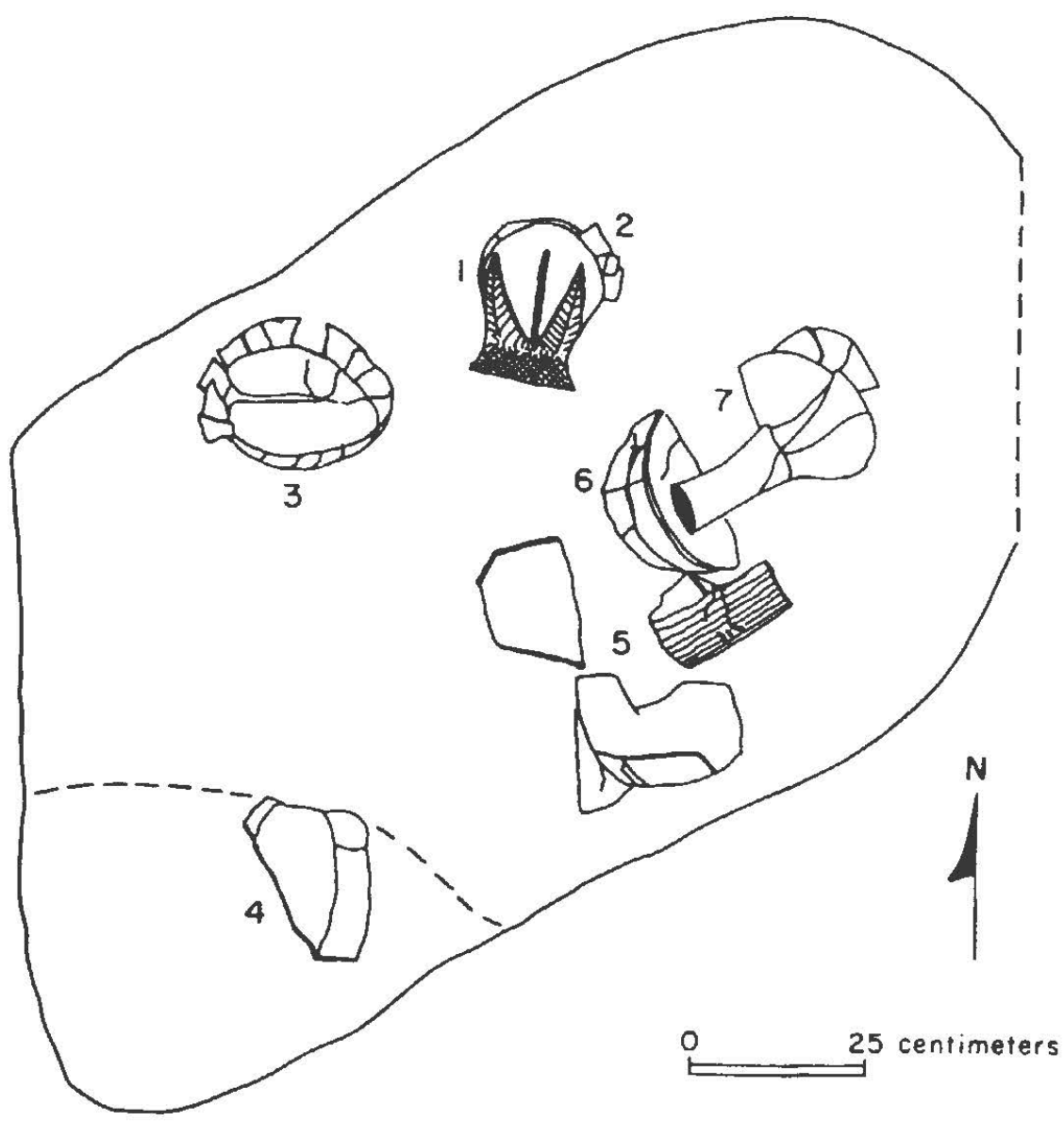

Figure 8. Plan of Burial No. 1, showing locations of grave goods. Numbers refer to vessels listed in Table 9.

contact level only $50 \mathrm{~cm}$ outside the burial pit, and a Maud arrowpoint was found on backdirt from the burial pit. Both are assumed to be displaced from Burial No. 2 (Table 2).

All of the pottery vessels in Burial No. 2 were substantially complete except for Vessels No. 5 and 6. These two vessels had apparenuly been stacked or nested near the feet, and were crushed when a large tree root grew through them, for large parts of these vessels are missing. Vessels were in the shoulder and feet areas of the burial pit. 


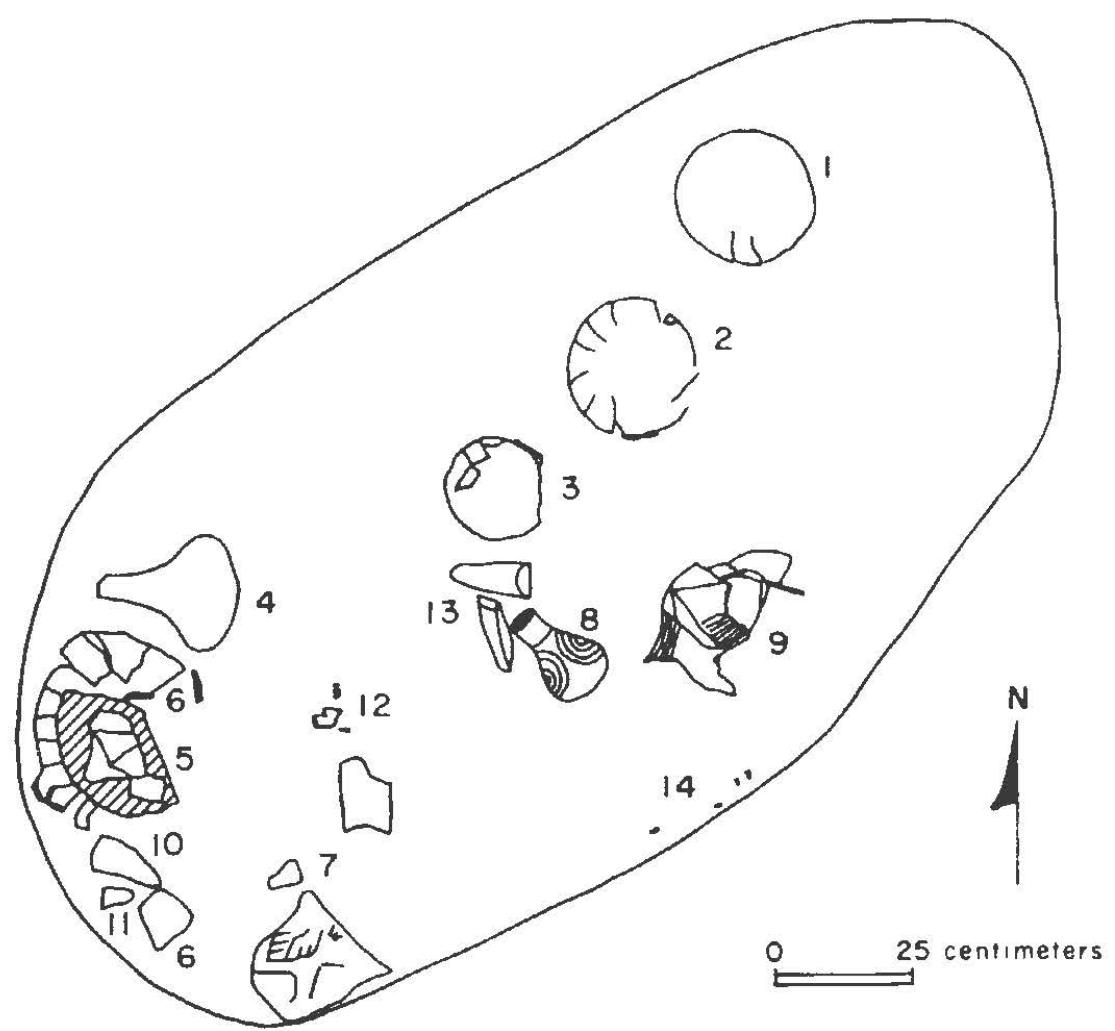

Figure 9. Plan of Burial Pit 2, showing locarions of Grave Goods. Numbers 1-9 refer to vessel numbers listed in Table 11. Numbers 10 and 11 are ferruginous sandstone tools, Number 12 refers to an engraved flaring bowl ceramic elbow pipe and four arrowpoints, Number 13, to two greenstone celts, and Number 14, to four Maud arrowpoints.

\section{Cemeteries of the Dry Creek Drainage}

Cemeteries of the Dry Creek drainage are usually small in size, averaging 10 individuals (subadults and adults) each; children were placed in pits below house floors. Cemeteries in Dry Creek are small when compared to Late Caddoan cemeteries along Big Cypress Creek and its tributaries (Tumer 1978; Thurmond 1981). Burials are single, extended inhumations with burial goods-ceramic vessels, petaloid celts, ceramic elbow pipes, and arrow points-at the sides, 
1 Engraved ccramic elbow pipe

5 Ripley Engraved carinated bowls

1 Wilder Engraved botule

1 Taylor Engraved boutle

2 Nash Neck-Banded jars
2 Ferruginous sandstone tools

2 Greenstone celts

8 Maud arrowpoints

1 Talco arrowpoint

1 Bassett arrowpoint

shoulders, and about the heads of the individuals. Ceramic vessels used as grave goods include not only locally manufactured Ripley Engraved, Wilder Engraved, McKinney Plain, and Maydelle Incised, but also wares such as Avcry Engraved and SimmsEngraved that may have bcen manufactured on the Red River and exchanged with Titus phase groups in the Upper Sabine River Basin (Thurmond 1985:193).

The small size of the cemeteries, their demographic profiles of roughly equal adult male and female representation, few adolescents, and no children, plus limited evidence for internal rank differentiation, all are indicative of the type of mortuary population expected in family units occupying a household for only a short period of time (Rose 1984:240; Shafer 1981:156). Burials in the household cemeteries occur as single interments in patterned arrangements of burials oriented and placed by spacing considerations that are duplicated in cemeteries from each of the Titus phase spatial clusters (e.g., Thurmond 1981, 1985).

According to Thurmond (1981:455-456),

adolescents were buried with more offerings than children or infants, and with fewer offerings than adults. The graves of males often contain clusters of arrowpoints in patterns suggesting quivers of arrows, and those of females contain polishing stones or more numerous pottery vessels. Items of exotic material ... are extremely rare. The occurrence of graves containing very large numbers of artifacts is also quite limited.

In the absence of identifiable skeletal remains from the Goldsmith site, the grave goods suggest that Burial No. 1 was probably an adult female and Burial No. 2 was an adult male. However, without a body of data on grave goods associations in cases where skeletal material permits determination of age and gender, this can be considered only the merest suggestion.

Because grave goods at Goldsmith are comparable wo those in more intensively investigated Titus phase cemeteries (Table 3), monuary practices are probably the same throughout the Cypress Cluster, as noted earlier by Thurmond (1981). Included in the total of artifacts at the Goldsmith site are data from a local collector on a third burial that had been exposed in the road cut. That burial contained one small plain jar, one large utility jar with incised lines at the rim/body juncture, five 
Ripley Engraved bowls, one Simms-like bowl form, a plain compound bowl similar in shape to some of the Avery Engraved and Ripley Engraved forms noted in the Dry Creek basin (e.g., Suhm and Jelks 1962: Plates 2B, 64,65), and one greenstone celt.

Table 3. Grave Goods From Four Titus Phase Cemeteries

\begin{tabular}{lccccl}
\hline \multicolumn{1}{c}{ Site } & $\begin{array}{c}\text { Mean No. } \\
\text { Ceramic } \\
\text { Vessels } \\
\text { Per Burial }\end{array}$ & $\begin{array}{c}\text { Mean No. } \\
\text { Projectile } \\
\text { Points } \\
\text { Per Burial }\end{array}$ & $\begin{array}{c}\text { Mean No. } \\
\text { Total } \\
\text { Speci- } \\
\text { mens }\end{array}$ & Burials & Reference \\
\hline Tuck Carpenter & 9.2 & 4.34 & 14.8 & 44 & Turner 1978 \\
Taylor & 8.3 & 5.09 & 14.5 & 71 & Thurmond 1981 \\
Alex Justiss & 7.3 & 6.88 & 15.4 & 25 & Bell 1981 \\
Goldsmith & 8.66 & 3.33 & 13.7 & 3 & This repon \\
\hline
\end{tabular}

\section{TEST EXCAVATIONS AT THE GOLDSMITH SITE TRASH MIDDEN}

Test excavations were conducted at the Goldsmith site trash midden in an attempt to obtain a controlled sample of artifacts and ecofacts associated with the nonmortuary life of the people who used the cemetery. Midden excavations in Titus phase occupations in the Upper Sabine River Basin are still rather limited, compared to cemctery excavations, but they are obviously a necessary priority in attempts to arrive at a balanced understanding of Titus phase lifeways.

The midden, which was estimated to cover about a 50-square-meter area, had been partially disturbed by road construction and illegal digging, and many sherds, fragments of bone and mussel shell, and charcoal flecks were noted on the backdir of the potholes.

The goals of the test excavations were (1) examine the subsurface context of the archeological deposit and assess its integrity, (2) obtain stratigraphic artifactual data, and (3) find in situ ceramic sherds of suitable size for thermoluminescence dating. Only a few areas in the midden were accessible for test excavations because of pothunter disturbances along the midden edge exposed in the roadcut. However, an area near the roadcut that was outside these disturbed areas and did not require extensive clearing (see Figures 2 and 5) was chosen, and two 1-by-1-meter units were cleared and excavated in arbitrary $10-\mathrm{cm}$ levels to 40 to $50 \mathrm{~cm}$ below the surface.

\section{Stratigraphy and Character of the Midden}

Stratigraphy was relatively simple in the midden (Figure 10). Exposed first was a 9-to-14-cm thick, gray, organic-rich A-horizon plow zone in which cultural 
materials, particularly ceramic artifacts, occur in quantity. Underlying the plow zone is a dark gray to black (10YR3/2-10YR2/2) charcoal- and ash-mottled midden deposit 12 to $23 \mathrm{~cm}$ thick. The midden contains extensive amounts of ceramics and bone, as well as charred nutshells and fragments of freshwater mussel shell. Ceramics in the midden are larger than in the plow zone, but are not necessarily more common by number or weight. The densest accumulation of cultural materials is at the base of the midden, which is extensively disturbed by rodent krotovinas (burrows) and root action as well. A thermoluminescence sample of a Ripley Engraved bowl with a scroll motif was recovered from $28 \mathrm{~cm}$ below the surface in the midden, but a date could not be obtained because the sherd had anomalous fading (e.8., Aitken 1985:54-59). The midden rests on a gray-yellow sand subsoil in which cultural materials are quite common; sterile deposits were not reached in these limited test excavations.
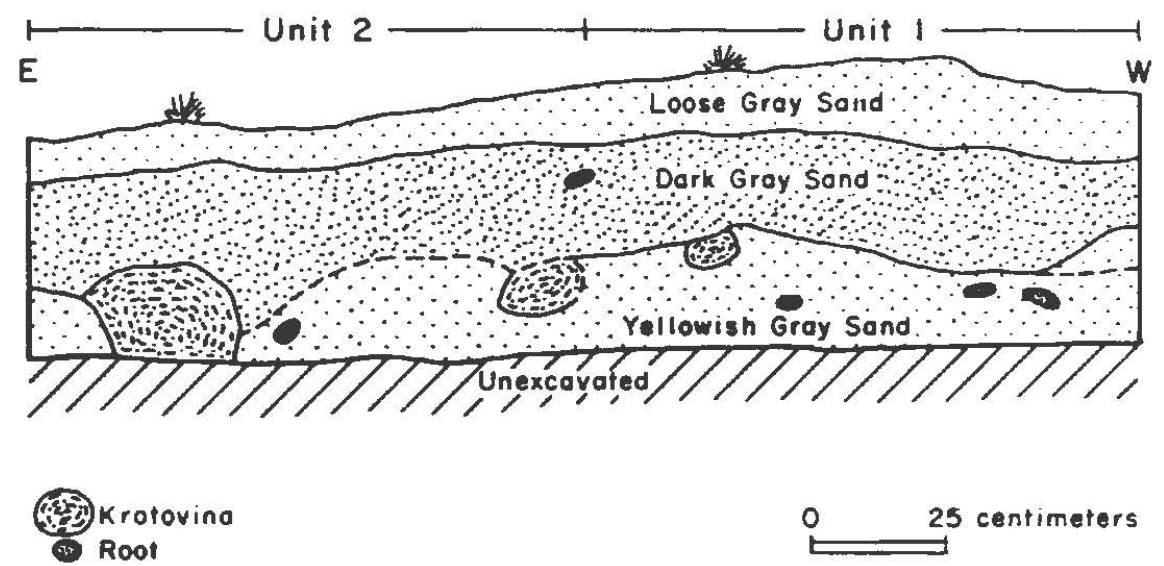

Figure 10. Stratigraphic profile in the midden at the Goldsmith site.

\section{Zooarcheological Remains in the Upper Sabine Basin}

Zooarcheological assemblages recovered from the Taddlock (4 1WD482) and Steck (41WD529) sites in the Upper Sabine Basin document the fact that considerably heterogenous faunal populations were present about A.D. 1000 to 1600 (Perttula and Bruseth 1983; Perttula et al. 1983). Recovered from Taddlock were faunal elements from 16 species of mammals, 12 species of birds, 8 species of reptiles or amphibians, and 9 species of fish. Several of the bird species were not permanent East Texas residents, including the pied-bill grebe, green-wing teal, and yellow-shafted flicker, but the majority of the animals recovered from Taddlock are year-round inhabitants of East Texas. The habitat range of species indicates that most animals were associated with an open oak-hickory forest with many grassland 
areas, which is to be expected, since the Taddlock site is in the Post Oak Savannah (Pertula and Bruseth 1983:11). The most common species represented at Taddlock are deer, racoon, beaver, squirrel, jackrabbit, opossum, turkey, carp sucker, freshwater drum, and catfish. Similar arrays of exploitable species can be expected in the Dry Creek basin, since both the Piney Woods and discrete stands of pine are typically faunal-poor habitats, and the majority of species hunted would be in upland hardwoods and bottomland forests.

Dog was recovered at the Steck site in the Piney Woods (Perttula et al. 1983) and was an important component of prehistoric and historic hunting forays in the region (Yates 1986). Bear and bison, utilized historically by Caddoan peoples in East Texas (Swanton 1942:134-137), were present in the western part of the Gulf Coastal Plain. Bison were never very common in the East and North Texas prairies, however, until the late 1700s (see Flores 1985:114), and there is no concrete evidence of the exploitation of bison in the Upper Sabine Basin until the eighteenth century (Lorrain 1967:Table 11).

\section{Faunal Remains in the Goldsmith Site Midden}

Faunal remains were common throughout the Goldsmith site midden deposit, averaging 143 elements per $\mathrm{m}^{3}$. Species identified are white-tailed deer, dog, pocket gopher, turkey, and land turtle. In character, the faunal assemblage from Goldsmith resembles that recovered from the nearby Steck site, a single component Late Caddoan occupation (Perttula et al. 1983:Table 4).

All of the six identified deer elements are burned or charred and represent parts of the carcass that have very little meat (i.e., the distal metapodial, a calcaneum with butcher marks, astragalus, and phalanx 1). These elements are lower leg bones that may have sustained fire damage when exposed to roasting of a hind leg. Long-bone fragments of deer-sized mammals constitute the majority of the unidentified faunal elements, and 83 percent of these are also burned. Only two deer are indicated in the small sample: an adult individual, represented by the lower leg bones and a vertebral fragment, and an immature individual represented by a scapula fragment that was also bumed.

The canid remains indicate three individuals. Each identified element is from an individual of a different age group based on skeletal development. A fetal or neonatal canid is represented by an unburned left distal humerus, an immature but older $\mathrm{dog}$ is identified by an unfused proximal metapodial (burned), and a small but fully adult individual is represented by an unburned lumbar vertebra. None of these elements is directly assignable to the domestic dog, but dog remains have been recorded in burials from several Late Caddoan sites in Wood County, including Steck, L. L. Winterbauer, M.E. Day, Pine Tree Farm, and the Dog site (Hockensmith 1977; Wilson and Jackson 1930; Robert Turbeville, personal communication).

Two elements—a left coracoid process and a left tarsometatarsus — of a single wild turkey (Meleagris gallopavo) were recovered in the midden; both elements have been burned. Based on the size of the coracoid process it seems likely that the 
turkey was a small female; turkey-size burned and unbumed faunal clements were also noted in the zooarcheological assemblage.

One box turtle (Terrapene sp.) is represented by 14 elements, 10 of which have been burned. Both carapace and plastron fragments were recovered in the midden. The pocket gopher (Geomys bursarius) is represented by a relatively complete and unburned skull; this individual, a burrowing animal, is probably the result of postoccupational intrusion.

Mussel shell and gastropods were present throughout the midden in small quantities; the mussel shells, most likely procured from Dry Creek, were primarily fragmented valves that cannot be identified to species.

\section{Floral Remains}

Charred hickory and pecan nutshells were observed in the coarse-screened (quarter-inch) debris. Flotation samples were not obtained during this phase of excavations, but would be essential to an accurate characterization of the paleobotanical assemblage at the Goldsmith site (e.g., Perttula et al. 1983).

\section{Artifact Assemblage in the Midden and Burials}

Considering the limited extent of the investigations at the Goldsmith site, a substantial amount of cultural debris was recovered in the midden deposits and burials. Plain and decorated sherds were especially common, but lithic debris and ecofactual remains were also present throughout the midden (Table 4), and whole vessels and complete, unbroken stone tools were found in the burials.

\section{Lithic Artifacts}

A small lithic assemblage of unmodified debris, fure-cracked rock, and several modified or completed tools has been recovered from the midden. Lithic tools and debris occur at a density of about 80 artifacts $/ \mathrm{m}^{3}$, which is low compared to Archaic and Early Caddoan occupations in the Upper Sabine River Basin. Other Late Caddoan assemblages in the basin, however, share this functional/technological characteristic with the Goldsmith site (see Bruseth and Pertula 1981:Table 6-4; Perttula 1984). Most of the lithic debris and fire-cracked rock is probably associated with a Late Archaic occupation rather than with the Titus phase occupation, since lithic artifacts are scarce in Late Caddoan sites in the Upper Sabine River Basin.

The lithic debris is dominated by raw materials that are locally available, including Ogallala quartzite from upland gravel sources. Other quartzites constitute 7.6 percent of the assemblage, and cherts, another 9.1 percent. Chert raw materials are gray, tan, and brown cherts of local origin, and a creamy white chert of unknown provenience. This white chert, with discernible black inclusions, closely resembles the Frisco chert (Banks 1984:85) that comes from the Arbuckle Mountains of southeastem Oklahoma and is available as close as the gravels of the Red River below the mouths of the Blue River and Clear Boggy Creek in Lamar and Fannin counties, Texas. Inspection of Frisco chert from Marshall County, Oklahoma, in 
Table 4. Distribution of Cultural Materials From the Goldsmith Site Midden

\begin{tabular}{|c|c|c|c|c|c|c|c|c|c|c|c|}
\hline Context & $\begin{array}{l}\text { Lthic } \\
\text { Debris }\end{array}$ & Tools & FCR* & Fauna & $\begin{array}{l}\text { Mussel } \\
\text { Shell } \\
\text { Frag- } \\
\text { ments }\end{array}$ & $\begin{array}{c}\text { Gastro- } \\
\text { pods }\end{array}$ & $\begin{array}{c}\text { Charred } \\
\text { Nut- } \\
\text { shells }\end{array}$ & $\begin{array}{l}\text { Plain } \\
\text { Sherds }\end{array}$ & $\begin{array}{l}\text { Decorated } \\
\text { Sherds }\end{array}$ & $\begin{array}{c}\text { Burned } \\
\text { Clay/ } \\
\text { Daub }\end{array}$ & $\mathbf{N}$ \\
\hline Surface & 9 & 3 & 1 & 3 & 2 & - & - & 11 & 2 & 1 & 32 \\
\hline $\begin{array}{l}\text { Unit 1, } \\
0-10 \mathrm{~cm}\end{array}$ & 9 & - & - & 10 & 4 & 1 & 1 & 53 & 10 & 11 & 99 \\
\hline $10-20 \mathrm{~cm}$ & 6 & - & - & 17 & - & 4 & - & 23 & 11 & 2 & 63 \\
\hline $20-30 \mathrm{~cm}$ & 4 & - & - & 18 & 5 & 1 & 4 & 37 & 14 & - & 83 \\
\hline $30-40 \mathrm{~cm}$ & 10 & 1 & 2 & 28 & 3 & 1 & - & 59 & 22 & 1 & 127 \\
\hline $\begin{array}{l}\text { Unit 2, } \\
0-10 \mathrm{~cm}\end{array}$ & 7 & . & - & 5 & 2 & - & 1 & 22 & 6 & 1 & 44 \\
\hline $10-20 \mathrm{~cm}$ & 7 & 1 & 1 & 9 & 3 & - & 1 & 17 & 2 & 2 & 43 \\
\hline $20-30 \mathrm{~cm}$ & 7 & 1 & - & 10 & 4 & 3 & 3 & 20 & 10 & - & 58 \\
\hline $30-40 \mathrm{~cm}$ & 7 & - & 2 & 14 & 4 & 1 & 1 & 39 & 10 & 1 & 79 \\
\hline TOTALS & 66 & 6 & 6 & 114 & 27 & 11 & 11 & 281 & 87 & 19 & 628 \\
\hline
\end{tabular}

*FCR = Fire-cracked rock. 
collections at the Oklahoma Archeological Survey confirmed the similarity. This raw material is found in a number of assemblages, primarily of Middle-Late Archaic attribution, in the Upper Sabine River Basin (Pertula et al. 1986).

Eighty-two percent of the lithic debris consists of noncortical tertiary elements; only one primary element (cortex covering the entire dorsal surface) and 11 secondary elements (cortex present on the dorsal surface of the piece) were noted. The high frequency of tertiary elements and the small size of the lithic debris indicate that tool maintenance and resharpening activities are primarily responsible for the composition of the lithic debris assemblage. This is consistent with the probable functional nature of the Late Archaic occupation at Goldsmith.

Tools identified from the surface and the midden excavations are one ferruginous sandstone mano, one quartzite hammerstone, one unifacially modified piece made of a local gray chert, one chert straight-stemmed dart point (or projectile point/ knife), and two arrowpoints. The dart point is a resharpened implement, possibly of the Yarbrough type (Johnson 1962). The arrowpoints, manufactured of local cherts from the Uvalde gravels, resemble the Maud and Bassett types common in the Titus phase, and were also recovered in Burial 2 (Figure 11, $c-n$ ).

In Burial No. 2 were found eight Maud, one Talco, and one Bassett arrowpoint (Table 5). A few pieces of lithic debris were also recovered in the burial fill, including five chert (four of which were noncortical), one Ogallala quartzite (a cortical element), two quartzite (one of which is a cortical element), and one ferruginous sandstone cortical element. In shovel skimming above Burial No. 1, a Gary variety Camden (see Schambach 1982:Table 7.2) projectile point was found (Figure 11, A), together with a single, small (less than $4 \mathrm{~cm}$ long and wide) quartzite bumed rock, five tertiary elements of chert (two of which have use-wear patterns), and a fragment of a pitted hematite stone. None of this lithic material found while excavating Burials No. 1 and 2 seems definitely relatable to the Titus phase occupation at the Goldsmith site.

The two celts from Burial No. 2 were made by pecking and/or flaking large cobbles of greenstone (a siliccous shale lithic raw material available only in the Ouachita Mountains of southeastern Oklahoma [Banks and Winter 1975:27]), then grinding and polishing the face and bit of the tool. They have tapered poll ends, convex bit profiles with angles between 65 and 75 degrees, and bit widths ranging from 4.6 to $5.1 \mathrm{~cm}$. The celts (Figure 12, A, B) are $9.8 \mathrm{~cm}$ and $12.6 \mathrm{~cm}$ long and resemble the Type I and II celts defined at the Roitsch (Sam Kaufman) site in Red River County (Ferring 1969:88-89); Type II ceIts were the most common type at Lake Fork Reservoir Caddoan sites (Bruseth and Perttula 1981). The ferruginous sandstone tools are cobble-sized pieces of raw material that have been minimally shaped by percussion-flaking along the edges of the piece (Figure 12, C, D). Some cortex remains on both tools, but only remnants are visible on the circular, more extensively worked example. No use-wear can be scen along the worked cdges to indicate that they might be digging tools.

The high frequency of the use of local lithic raw materials, the recovery of Archaic Period projectile points (including those found by collectors), the presence 


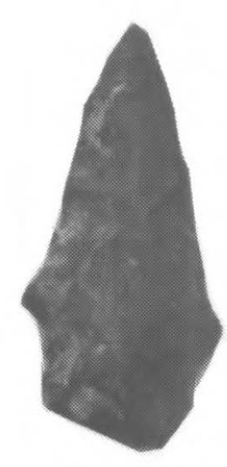

A

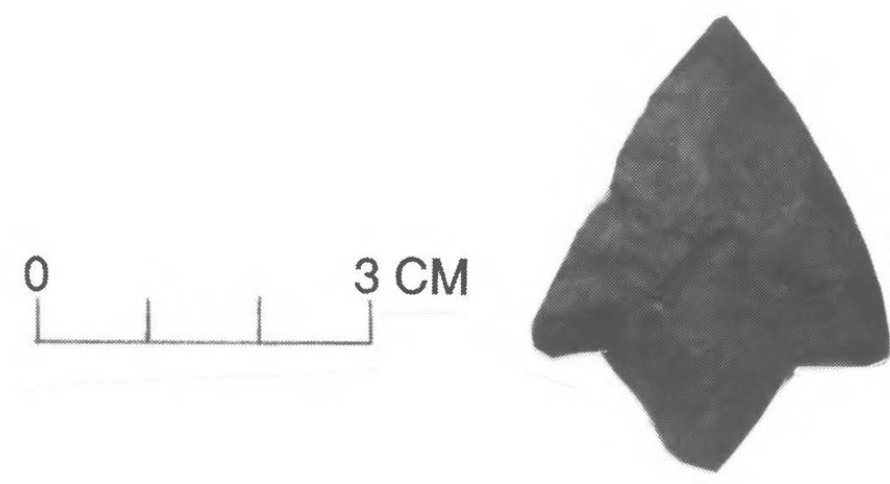

B
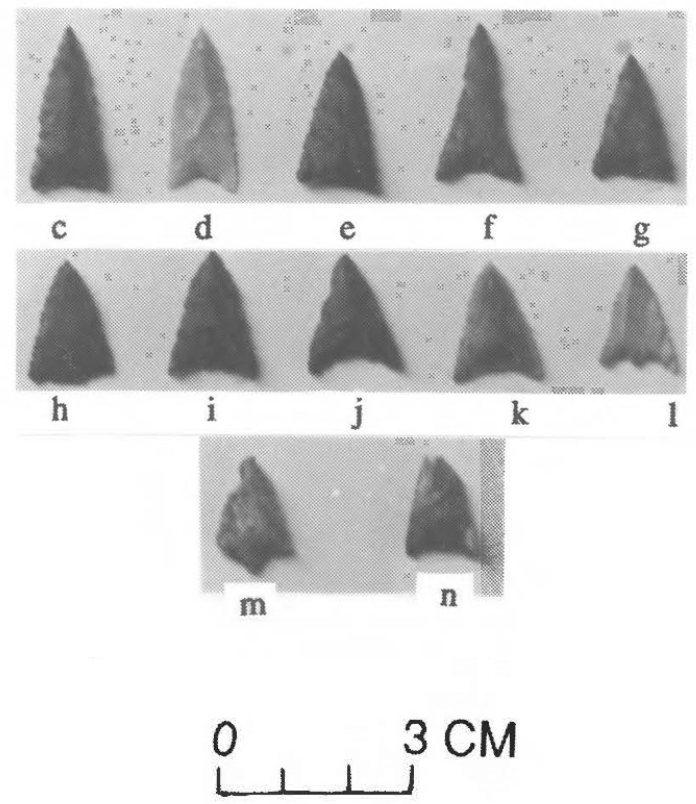

Figure 11. Chipped stone tools from the Goldsmith site.

of fire-cracked rock, and the appearance of a Frisco-like white chert in a nonburial context all point primarily to an Archaic age. Middle and Late Archaic assemblages in Lake Fork Reservoir, $20 \mathrm{~km}$ to the west, are notable for the use of local materials 
Table 5. Projectile Point Attribute Data.

\begin{tabular}{|c|c|c|c|c|c|c|c|c|c|c|c|}
\hline Context & $\begin{array}{l}\text { Max. } \\
\text { Length }\end{array}$ & $\begin{array}{l}\text { Max. } \\
\text { Width }\end{array}$ & $\begin{array}{c}\text { Max. } \\
\text { Thick- } \\
\text { ness }\end{array}$ & $\begin{array}{c}\text { Blade } \\
\text { Length }\end{array}$ & $\begin{array}{l}\text { Blade } \\
\text { Width }\end{array}$ & $\begin{array}{c}\text { Haft } \\
\text { Length }\end{array}$ & $\begin{array}{c}\text { Haft } \\
\text { Width }\end{array}$ & $\begin{array}{c}\text { Serra. } \\
\text { ted }\end{array}$ & $\begin{array}{c}\text { Heat } \\
\text { Treated }\end{array}$ & Raw Material & Type \\
\hline Unit 1, Level 4 & 17.0 & 10.5 & 2.5 & 14.5 & 10.5 & 2.5 & 3.0 & & & Gray chert & Bassett \\
\hline Unit 2, Level 2 & - & 10.2 & 2.5 & - & 10.2 & - & 10.2 & & & Black-gray chert & Maud \\
\hline Burial No. 2 & 16.5 & 11.0 & 1.3 & 16.0 & 11.0 & 0.5 & 2.0 & + & & Gray chert & Bassett \\
\hline Burial No. 2 & 26.1 & 10.5 & 2.0 & 26.1 & 10.5 & - & 10.5 & + & + & Chalcedony & Talco \\
\hline Burial No. 2 & 20.2 & 11.8 & 2.8 & 20.2 & 11.8 & - & 11.8 & + & & Ogallala quartzite & Maud \\
\hline Burial No. 2 & 20.2 & 12.9 & 3.3 & 20.2 & 12.9 & - & 12.9 & + & & Red-gray quartzite & Maud \\
\hline Burial No. 2 & 26.0 & 12.6 & 2.2 & 26.0 & 12.6 & - & 12.6 & & & Red quartzite & Maud \\
\hline Burial No. 2 & 19.0 & 12.8 & 2.7 & 19.0 & 12.8 & - & 12.8 & + & + & Chalcedony & Maud \\
\hline Burial No. 2 & 18.5 & 12.2 & 2.5 & 18.5 & 12.2 & - & 12.2 & + & & Ogallala quartzite & Maud \\
\hline Burial No. 2 & 27.0 & 11.0 & 3.0 & 27.0 & 11.0 & - & 11.0 & + & & Ogallala quartzite & Maud \\
\hline Burial No. 2 & 23.0 & 11.8 & 2.9 & 23.0 & 11.8 & - & 11.8 & + & & Red quartzite & Maud \\
\hline Burial No. 2 & 19.1 & 13.1 & 3.0 & 19.1 & 13.1 & - & 13.1 & + & & Gray quartzite & Maud \\
\hline Surface & 39.0 & 19.2 & 9.0 & 30.2 & 19.2 & 8.8 & 14.3 & & & Ogallala quartzite & Yarbroug \\
\hline Above Burial \# 1 & 42.5 & 31.8 & 6.5 & 32.5 & 31.8 & 10.0 & 14.0 & + & & Ogallala & Gary \\
\hline
\end{tabular}

$+=$ present 
Perttula, Skiles, and Yates - Goldsmith Site

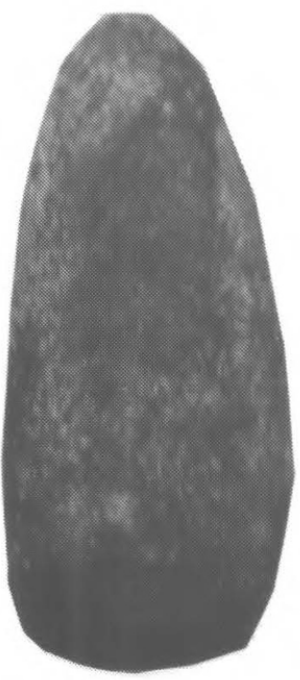

A

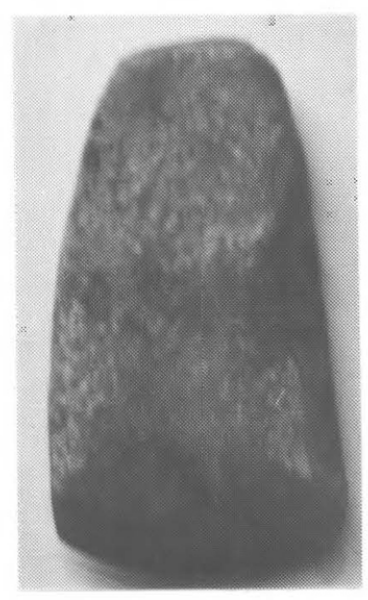

B
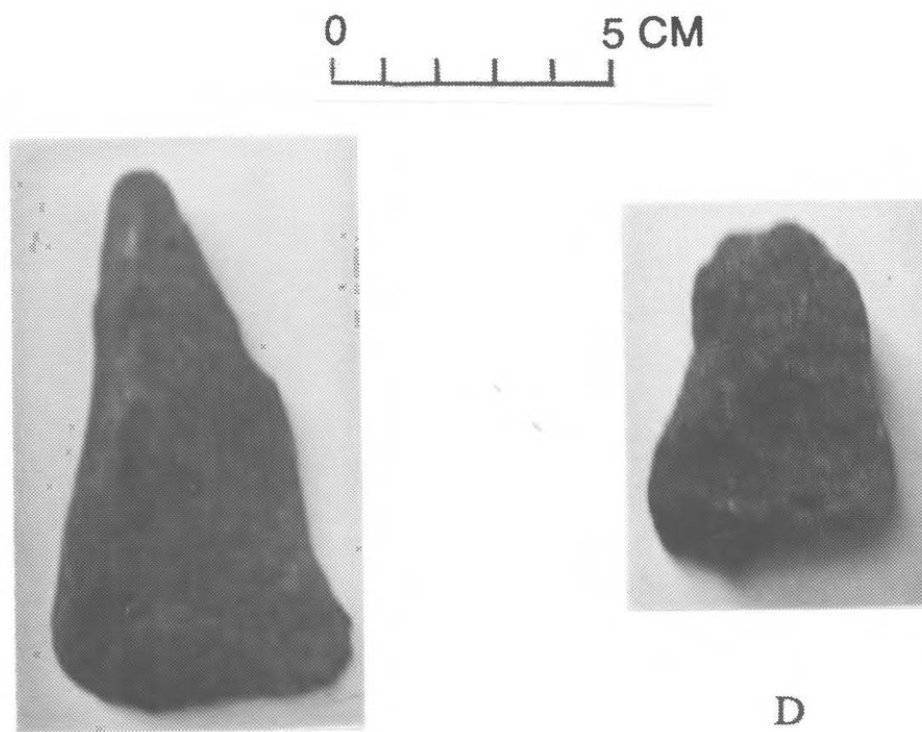

D

C

Figure 12. Celts and ferruginous sandstone tools from Burial No. 2. 
in the reduction and production of lithic tools (Bruseth and Perttula 1981:Table 69; Perttula 1984:Table 7.3), particularly in comparison to Caddoan assemblages dating between A.D. 1000 and 1400. Densities of fire-cracked rocks decrease noticeably after about A.D. 800 in the same set of sites. The Frisco-like white chert has been identified in Early Archaic to Late Archaic contexts in several sites in the Big Sandy Creek basin east of the Goldsmith site (Pertula et al. 1986), most noticeably in putative Early and Middle Archaic components at the Trammell Crow Pond site (41WD185). The Frisco-like white chert is not a common raw material in the Big Sandy Creek basin, but its periods of use may well aid in the chronological ordering of Archaic assemblages in the absence of datable materials.

\section{Ceramic Artifacts}

Ceramic sherds are the most common artifacts in the Goldsmith midden, occurring in quantities of as many as $460 \mathrm{sherds} / \mathrm{m}^{3}$. Considering this estimated density, the midden probably contains about 9,000 sherds, all probably deposited within a relatively short time span.

Three hundred sixty-eight sherds have been recovered from the midden or its surface (Table 6). Grog-tempered sherds comprise 93 percent of the assemblage, followed by grog/grit-tempered sherds ( 3 percent), and grog/bone and bonetempered specimens ( 2 percent). Five sherds have no discernible temper. These differences in temper correspond to those in Late Caddoan occupations at Lake Fork Reservoir and in the Dry Creek basin in Wood County. Bone is most commonly used as an aplastic in Early Ceramic period and Early Caddoan period occupations, ranging between 7 and 70 percent in ceramic assemblages at Lake Fork Reservoir (Bruseth and Perttula 1981:Table 5-7). At the Steck site, bone temper was present in only 0.5 percent of the sherds, whereas bone was noted in 0.3 percent of the sherds from the contemporaneous Late Caddoan Pine Tree Farm site (J. E. Bruseth, personal communication, April 1987).

Inspection of cross sections of grog-tempered sherds suggests that more finely crushed grog is used almost exclusively in Ripley Engraved vessels, and occasionally in the manufacture of Nash Neck-Banded or LaRue Neck-Banded jars. The coarser paste with grog/grit temper is confined to sherds of the utility ware types Harleton Appliqué, Kamack Brushed-Incised, and McKinney Plain (Suhm and Jelks 1962) with appliqué, or brushing/appliqué. These paste differences presumably relate to technological and functional variability in the way these kinds of vessels were made and designed to be used (e.g., Steponaitis 1984:85-114).

Decorated sherds comprise 24 percent of the ceramic assemblage and are dominated by engraving, neck banding, and various forms of appliqué (Table 7). Roughly 80 percent of the 34 rims are decorated, which is an additional measure of the pervasiveness of decorated vessels in the Titus phase occupation at the Goldsmith site.

All of the engraved sherds with rolled or folded rims characteristic of the Titus phase lip treatment on carinated bowls are identified as Ripley Engraved (Figure 
Table 6. Ceramics From the Goldsmith Site Trash Midden

\begin{tabular}{|c|c|c|c|c|c|c|c|c|c|c|c|}
\hline \multirow[b]{2}{*}{ Context } & \multicolumn{5}{|c|}{ RIM AND DECORATED SHERDS } & \multicolumn{4}{|c|}{ PLAIN BODY SHERDS } & \multirow{2}{*}{$\frac{\text { BASE }}{\text { Grog }}$} & \multirow[t]{2}{*}{$\mathbf{N}$} \\
\hline & Grog & $\begin{array}{c}\text { Grog/ } \\
\text { grit }\end{array}$ & None & Bone & $\begin{array}{c}\text { Grog/ } \\
\text { bone }\end{array}$ & Grog & $\begin{array}{l}\text { Grog/ } \\
\text { grit }\end{array}$ & $\begin{array}{l}\text { Grog/ } \\
\text { bone }\end{array}$ & Bone & & \\
\hline Surface & 2 & & & & & 9 & 2 & & & & 13 \\
\hline \multicolumn{12}{|l|}{ Unit 1} \\
\hline $0.10 \mathrm{~cm}$ & 8 & 2 & 1 & & 1 & 47 & & $1 *$ & 2 & 1 & 63 \\
\hline $10-20 \mathrm{~cm}$ & 11 & & & & & 22 & & & & $i$ & 34 \\
\hline $20-30 \mathrm{~cm}$ & 15 & & & & & 36 & & & & & 51 \\
\hline $30-40 \mathrm{~cm}$ & 18 & 2 & 1 & 2 & & $58 *$ & & & & & 81 \\
\hline \multicolumn{12}{|l|}{ Unit 2} \\
\hline $0.10 \mathrm{~cm}$ & 5 & 3 & & & & $19^{*}$ & & & & 1 & 28 \\
\hline $10-20 \mathrm{~cm}$ & 1 & & 1 & & & 16 & 1 & & & & 19 \\
\hline $20-30 \mathrm{~cm}$ & 9 & & 1 & & & $20^{*}$ & & & & & 30 \\
\hline $30-40 \mathrm{~cm}$ & 7 & 2 & 1 & & 1 & 38 & & & & & 49 \\
\hline TOTAL & 76 & 9 & 5 & 2 & 2 & 265 & 3 & 1 & 2 & 3 & 368 \\
\hline
\end{tabular}

* Red-slipped sherds are included in this category. 
Table 7. Distribution of Decorated and Rim Sherds from the Goldsmith Site Trash Midden

\begin{tabular}{|c|c|c|c|c|c|c|c|c|c|c|c|c|}
\hline Context & $\begin{array}{l}\text { Plain } \\
\text { Rim }\end{array}$ & Incised & $\begin{array}{l}\text { Incised/ } \\
\text { Appliqué }\end{array}$ & $\begin{array}{l}\text { Brushed- } \\
\text { Appliqué }\end{array}$ & Brushed & $\begin{array}{l}\text { Punctate- } \\
\text { Incised/ } \\
\text { Appliqué }\end{array}$ & Punctate & $\begin{array}{l}\text { Punctate- } \\
\text { Incised }\end{array}$ & Appliqué & $\begin{array}{l}\text { Neck- } \\
\text { Banded }\end{array}$ & Engraved & $\mathbf{N}$ \\
\hline Surface & & & & & & 1 & & & & & 1 & 2 \\
\hline \multicolumn{13}{|l|}{ Unit 1} \\
\hline $0.10 \mathrm{~cm}$ & 2 & & & & & & & 1 & 1 & 1 & 7 & 12 \\
\hline $10-20 \mathrm{~cm}$ & & 1 & & & 2 & & & & & 1 & 7 & 11 \\
\hline $20-30 \mathrm{~cm}$ & 1 & 1 & & & 2 & & & & 1 & 6 & 4 & 15 \\
\hline $30-40 \mathrm{~cm}$ & 1 & & 1 & 1 & 1 & & 1 & & 1 & 4 & 13 & 23 \\
\hline \multicolumn{13}{|l|}{ Unit 2} \\
\hline $0.10 \mathrm{~cm}$ & 2 & & & & & & 1 & & 3 & & 2 & 8 \\
\hline $10-20 \mathrm{~cm}$ & & & & & & & & & 1 & & 1 & 2 \\
\hline $20.30 \mathrm{~cm}$ & & 1 & & & & & & & & 5 & 4 & 10 \\
\hline $30-40 \mathrm{~cm}$ & 1 & & & & 2 & & & & 2 & 2 & 4 & 11 \\
\hline TOTAL & 7 & 3 & 1 & 1 & 7 & 1 & 2 & 1 & 9 & 19 & 43 & 94 \\
\hline
\end{tabular}


13). Stylistic motifs are generally difficult to determine because the sherds are so small, but motifs that could be identified include the scroll, scroll and circle, and the interlocking horizontal scroll (Thurmond 1985: Figure 3). These motifs are common in Three Basins subcluster sites of the Titus phase defined recently by Thurmond (1985:193).

Other treatments of the engraved sherds include a red hematite slip (sce Ferring and Perttula 1987) on both interior and exterior surfaces (4.7 percent of the engraved sherds), and the painting of engraved lines with hematite and kaolin (9.3 percent of the sherds). Only 2.2 percent of the plain body sherds have a red hematite slip.

Neck-banded sherds are derived from everted rim LaRue or Nash NeckBanded jars (Figure 14, c-e, h). Surface treatment of the neck-banded jars includes both smoothed rim coils and regularly crimped rim coils. The partially smoothed neck-banded sherds are tempered with fine grog paste; the remainder have been tempered with a much coarser grog. The neck-banded sherds comprise 22 percent of the decorated sherds, compared to engraved sherds, which comprise 49 percent of the decorated sherds. Sherds were designated LaRue/Nash Neck-Banded because it was not possible to differentiate the neck-banded sherds consistently according to the criteria proposed by Suhm and Jelks (1962:93, 111).

The high frequency of neck-banded sherds from the Goldsmith site is comparable with other Titus phase occupations in the Dry Creek and Little Dry Creek localities of the Three Basins subcluster, including the Steck and J. H. Reese sites (Hockensmith 1977; Wilson and Jackson 1930). However, this comparability is not duplicated at the Caney Creek localities in the Lake Fork Creek drainages (Bruseth and Peruula 1981; Thurmond 1985), where only 3 to 11 percent of the decorated sherds from the different middens at the Killebrew and Gilbreath sites have neck bands (Table 8 ).

Appliquéd sherds are probably derived from the McKinney Plain and Harleton Appliqué utility wares (Figure 14,f, g). The applique on plain rims usually consists of fillets and nodes that are placed so they divide the rims of large jars into quarters. The applique fillets are placed vertically from just below the lip to halfway to the rim-body juncture. Multiple inverted fillets (Figure 14, g) are also characteristic of locally produced McKinney Plain (see Bruseth and Pertbula 1981:Figure 5-8a, c); these are placed directly below the lips of the vessels. Applique also is used in combination with incised, brushed, and punctated decorations on Maydelle Incised, Karnack Brushed-Incised, and Harleton Appliqué types of the Titus phase (Suhm and Jelks 1962:65, 85, 103).

Brushed sherds are infrequent in sites of the Three Basins subcluster. At the Goldsmith site, only 8 percent of the decorated sherds are brushed; at the Swauano Creek and Big Cypress Creek subclusters they account for 40 to 60 percent of the utility vessels (e.g., Thurmond 1985:193). However, brushing is much more common in the Dry Creek locality during the Titus phase than it is in the Caney Creek locality 10 to $15 \mathrm{~km}$ to the west (Table 8). At Goldsmith, brushing is both vertical and horizontal, with vertical brushing of the body most frequent. One 

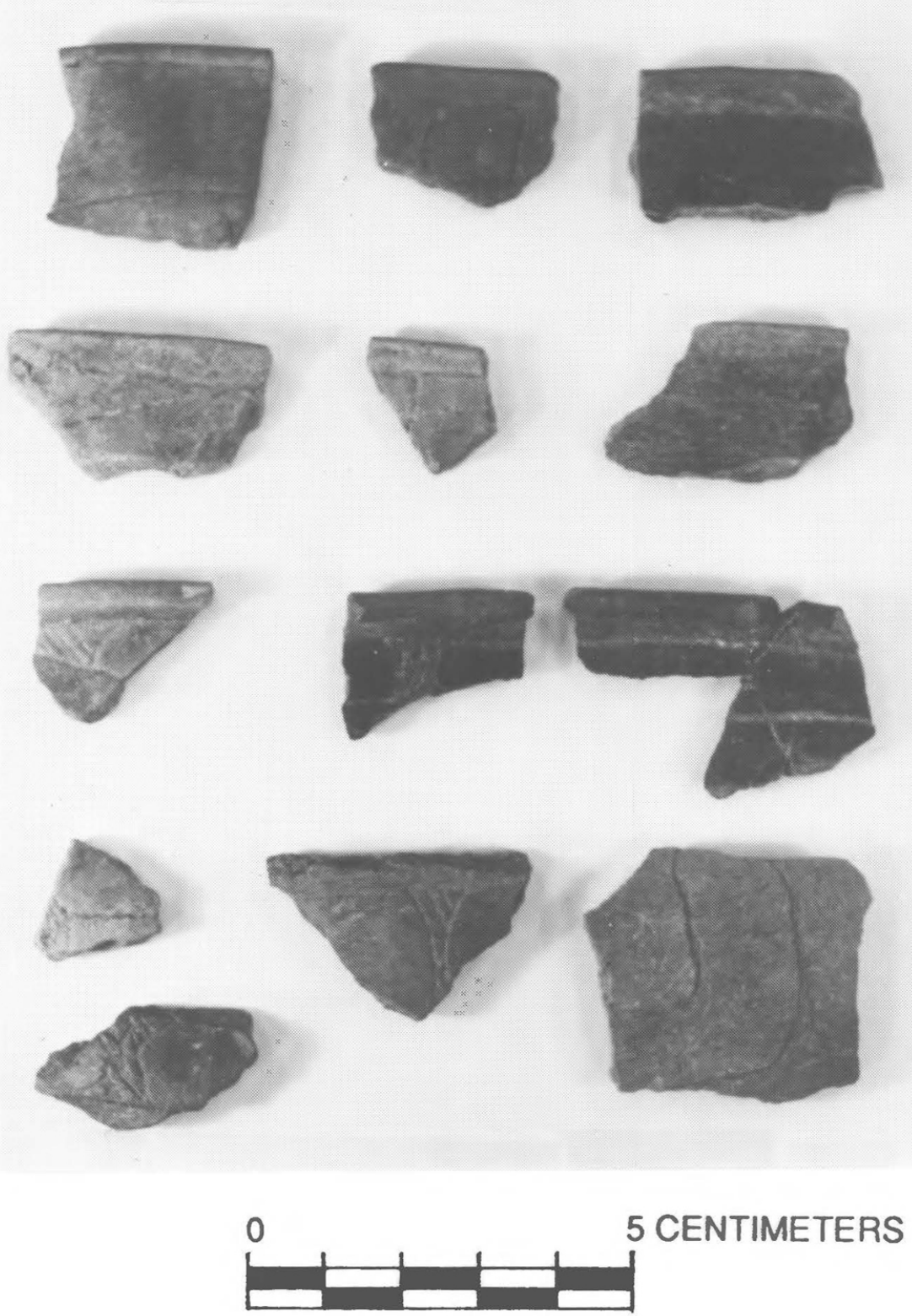

Figure 13. Engraved sherds from the Goldsmith site midden. 


\section{Perttula, Skiles, and Yates - Goldsmith Site}

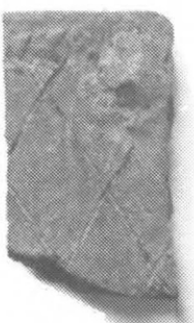

a

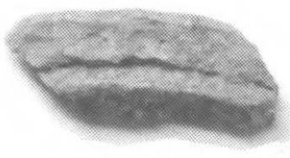

d

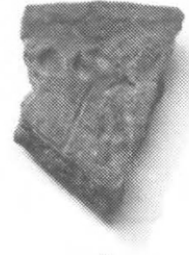

b

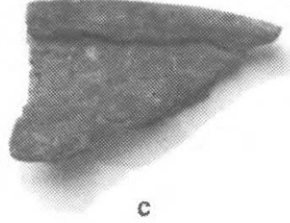

c

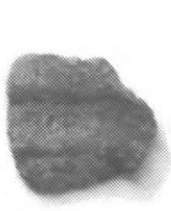

h

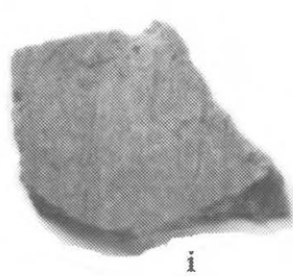

f

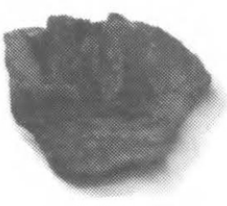

$\mathrm{g}$

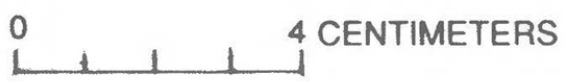

Figure 14. Neck-banded, appliqué, brushed, incised, and punctated sherds from the Goldsmith midden. 
Table 8. Relative Percentages of Decorative Treatments at Late Caddoan Sites in the

Dry Creek and Caney Creek Localities of the Upper Sabine River Basin.

\begin{tabular}{|c|c|c|c|c|c|c|c|}
\hline \multirow[b]{2}{*}{$\begin{array}{l}\text { Decorative } \\
\text { Method }\end{array}$} & \multicolumn{4}{|c|}{ DRY CREEK LOCALITY } & \multicolumn{3}{|c|}{ CANEY CREEK LOCALITY } \\
\hline & Burks & Steck & Goldsmith & Pine Tree & Gilbreath, A/B & Killebrew, D & Killebrew, B \\
\hline Engraving & 32.7 & 54.6 & 49.5 & 45.7 & 50.0 & 51.5 & 41.5 \\
\hline Neck Banding & 9.0 & 19.5 & 21.8 & 29.5 & 0 & 3.0 & 11.2 \\
\hline Appliqué & 6.2 & 11.0 & 10.3 & 20.1 & 15.8 & 15.1 & 15.1 \\
\hline Brushing & 22.5 & 7.7 & 8.0 & 0.8 & 0 & 0 & 0 \\
\hline Incision & 20.8 & 3.4 & 3.4 & 3.9 & 13.2 & 27.3 & 17.0 \\
\hline Punctation & 6.5 & 3.9 & 2.3 & 0 & 18.4 & 3.0 & 13.2 \\
\hline Total Decorated & 677 & 698 & 87 & 129 & 38 & 33 & 53 \\
\hline
\end{tabular}


Karnack Brushed-Incised sherd was identified from the midden; the other sherds from the midden are body sherds from Bullard Brushed, Maydelle Incised, and Harleton Appliqué utility jars.

Punctated and incised sherds are derived from the Maydelle Incised type (Figure $14 \mathrm{a}, \mathrm{b}$ ). The incised motifs are predominantely cross-hatched bands on the rims. Nodes and horizontal rows of stick and fingernail punctations are associated with the incised lines on the rim band. Bodies of these Maydelle Incised vessels, which include everted rim jars and carinated bowIs (relatively uncommon), range from plain to brushed (see Suhm and Jelks 1962:103).

The sixteen vessels found in Burials No. 1 and 2 comprise eight Ripley Engraved carinated bowls, one Harleton Appliqué jar, two Wilder Engraved bottles, one Taylor Engraved bottle, three Nash Neck-Banded jars, and a carinated bowl of typical Ripley Engraved form, but decorated only with a single engraved line on the vessel interior (Table 9). All of the vessels are grog tempered, but the amount of grog added to the paste is variable in and among the different types. Polished brown and black is the most common color, and none of the vessels has been slipped. White and red pigments have, however, been applied to the engraved designs on seven of the eight Ripley Engraved bowls, and on one of the Wilder Engraved bottles.

The Ripley Engraved carinated bowls have been divided into two size groups: (1) small, with orifice diameters less than $16 \mathrm{~cm}$ or heights less than $9 \mathrm{~cm}$ (Figure 15, D, E; Figure 16, H, 1); and (2) large, with orifice diameters greater than $25 \mathrm{~cm}$ and vessel heights between 13 and $18 \mathrm{~cm}$ (Figure 15,F, G; Figure 16, A). Decorative motifs vary within the two groups, although the scroll and circle (Thurmond 1985:Figure 3) is the most common bowl-rim motif (Figure 17). This motif is present on 63 percent of the Ripley Engraved bowls, and the nested triangle, interlocking scroll, and continuous scroll motifs account for the remainder of the assemblage (Table 9). The frequency of these motifs is consistent with Thurmond's (1985:193) description of the Three Basins subcluster of the Titus phase. At the nearby J.H. Reese site, the scroll and circle motif is most common in the large vessel sample (at the Texas Archeological Research Laboratory) from the cemetery excavated by $\mathrm{A}$. T. Jackson, followed by the continuous scroll, interlocking scroll, and a single example of the pendant triangle motif (Vessel No. 6).

A single example of Wilder Engraved (see Suhm and Jelks 1962:Plate 78M for an example from the J. H. Reese site) was found in each burial at the Goldsmith site. These are rather squat bottles with narrow, tapering necks (Figures 15, B and 16, C), decorated on the bodies with engraved spirals with hooked, excised arms. Vessel No. 7 in Burial No. 1 has red pigment in the engraved lines. Wilder Engraved is considered a local resident pottery type of the Three Basins subcluster (Thurmond 1985), although it is relatively uncommon compared to Ripley Engraved.

A black polished Taylor Engraved bottle with a spool neck and a flaring lip (Figure 16, D) was recovered from Burial No. 2. Engraved spirals cover the entire body. The Goldsmith example is very similar to Taylor Engraved bottles from the 
Table 9. Vessel Attribute Observations

\begin{tabular}{|c|c|c|c|c|c|c|c|c|c|}
\hline $\begin{array}{l}\text { Ves- } \\
\text { sel } \\
\text { No. }\end{array}$ & Form 1 & $\begin{array}{l}\text { Diameter } \\
(\mathrm{cm})\end{array}$ & $\begin{array}{l}\text { Orifice } \\
\text { Height } \\
(\mathrm{cm})\end{array}$ & $\begin{array}{l}\text { Tbickness } \\
\text { (mm) }\end{array}$ & $\begin{array}{l}\text { Lip } \\
\text { Profile }^{2}\end{array}$ & Temper $^{3}$ & $\begin{array}{l}\% \\
\text { Com- } \\
\text { plete }\end{array}$ & $\begin{array}{l}\text { Type and } \\
\text { Decorative } \\
\text { Motif }\end{array}$ & Comments \\
\hline \multicolumn{10}{|c|}{ BURIAL No. 1} \\
\hline 1 & $\mathrm{~J}$ & 15.3 & 22.0 & 5.5 & $\mathrm{R}$ & $\mathrm{G}$ & 100 & $\begin{array}{l}\text { Harleton } \\
\text { Appliqué }\end{array}$ & \\
\hline 2 & $\mathrm{CB}$ & 26.5 & 18.0 & 6.5 & R-RO & G & 95 & $\begin{array}{l}\text { Ripley } \\
\text { Engraved } \\
\text { nested triangle }\end{array}$ & \\
\hline 3 & $\mathrm{CB}$ & 25.5 & 13.8 & 6.0 & $\mathrm{R}-\mathrm{RO}$ & $\mathrm{G}$ & 95 & $\begin{array}{l}\text { Ripley-scroll } \\
\text { \& circle }\end{array}$ & \\
\hline 4 & $\mathrm{CB}$ & 25.0 & 13.0 & $8.0-8.5$ & R-RO & $c G$ & 50 & $\begin{array}{l}\text { Ripley-scroll } \\
\text { \& circle }\end{array}$ & \\
\hline 5 & J & 26.2 & 28.5 & 6.5 & R-RO & $c G$ & 95 & $\begin{array}{l}\text { Nash Neck- } \\
\text { Banded }\end{array}$ & $\begin{array}{l}\text { This jar has } \\
\text { extensive soot } \\
\text { deposits on the } \\
\text { vessel exterior. }\end{array}$ \\
\hline 6 & $\mathrm{CB}$ & 16.1 & 8.3 & 5.2 & $R \cdot R O$ & $c G$ & 95 & $\begin{array}{l}\text { Ripley-scroll } \\
\text { \& circle }\end{array}$ & \\
\hline 7 & BT & 5.5 & 25.0 & 3.4 & $\mathrm{R}$ & fG & 99 & $\begin{array}{l}\text { Wilder } \\
\text { Engraved }\end{array}$ & $\begin{array}{l}\text { Main body } \\
\text { diameter is } \\
16.7 \mathrm{~cm}\end{array}$ \\
\hline
\end{tabular}


BURIAL No. 2

\begin{tabular}{|c|c|c|c|c|c|c|c|c|c|}
\hline 1 & CB & 27.7 & 14.0 & 5.5 & R-RO & G & 95 & $\begin{array}{l}\text { Ripley-scroll } \\
\& \text { circle }\end{array}$ & $\begin{array}{l}\text { This vessel has } \\
\text { three earlier } \\
\text { probe holes in } \\
\text { the base and } \\
\text { body. }\end{array}$ \\
\hline 2 & $\mathrm{CB}$ & 18.0 & 8.0 & 4.0 & RO & fG & 95 & Ripley & $\begin{array}{l}\text { There is an in- } \\
\text { terior engraved } \\
\text { line at the cari- } \\
\text { nation of this } \\
\text { vessel. }\end{array}$ \\
\hline 3 & $\mathrm{CB}$ & 15.5 & 9.0 & 4.0 & $\mathbf{R}$ & G & 95 & $\begin{array}{l}\text { Ripley- } \\
\text { continuous } \\
\text { scroll }\end{array}$ & \\
\hline 4 & BT & 4.5 & 24.0 & 5.0 & N/A & $c G$ & 99 & $\begin{array}{l}\text { Wilder } \\
\text { Engraved }\end{array}$ & $\begin{array}{l}\text { Main body dia- } \\
\text { meter is } 20.0 \mathrm{~cm} \\
\text { The lip has been } \\
\text { broken or } \\
\text { ground down } \\
\text { prior to its } \\
\text { inclusion as a } \\
\text { a grave good. }\end{array}$ \\
\hline
\end{tabular}


Table 9. Continued

\begin{tabular}{|c|c|c|c|c|c|c|c|c|c|}
\hline $\begin{array}{l}\text { Ves- } \\
\text { sel } \\
\text { No. }\end{array}$ & Form 1 & $\begin{array}{l}\text { Diameter } \\
(\mathrm{cm})\end{array}$ & $\begin{array}{c}\text { Orifice } \\
\text { Height } \\
\text { (cm) }\end{array}$ & $\begin{array}{c}\text { Thickness } \\
(\mathbf{m m})\end{array}$ & $\begin{array}{l}\text { Lip } \\
\text { Profile }^{2}\end{array}$ & Temper ${ }^{3}$ & $\begin{array}{l}\% \\
\text { Com- } \\
\text { plete }\end{array}$ & $\begin{array}{l}\text { Type and } \\
\text { Decorative } \\
\text { Motif }\end{array}$ & Comments \\
\hline \multicolumn{10}{|c|}{ BURIAL 2, continued } \\
\hline 5 & $\mathrm{CB}$ & 26.5 & 18.0 & 6.5 & $\mathrm{R} \cdot \mathrm{RO}$ & G & 95 & $\begin{array}{l}\text { Ripley- } \\
\text { interlocking } \\
\text { scroll }\end{array}$ & \\
\hline 6 & $\mathrm{CB}$ & 30.0 & 14.5 & 5.0 & R-RO & G & $60-70$ & $\begin{array}{l}\text { Ripley-scroll } \\
\text { \& circle }\end{array}$ & $\begin{array}{l}\text { The height is an } \\
\text { estimate only } \\
\text { because of } \\
\text { partial } \\
\text { completeness }\end{array}$ \\
\hline 7 & J & 16.5 & 20.4 & 7.0 & R-RO & G & 99 & $\begin{array}{l}\text { Nash } \\
\text { Neck-Banded }\end{array}$ & \\
\hline 8 & BT & 6.1 & 19.4 & $4-5$ & $\mathrm{~F}$ & fG & 100 & $\begin{array}{l}\text { Taylor } \\
\text { Engraved }\end{array}$ & $\begin{array}{l}\text { Main body } \\
\text { diameter } \\
\text { is } 15.0 \mathrm{~cm} \text {. This } \\
\text { vessel has a } \\
\text { spool } \\
\text { neck in addition } \\
\text { to a flaring lip } \\
\text { profile }\end{array}$ \\
\hline
\end{tabular}




\begin{tabular}{lllllllll}
\hline $\mathrm{J}$ & 17.7 & 18.9 & 6.0 & R-RO & G & 95 & $\begin{array}{l}\text { Nash Neck- } \\
\text { Banded }\end{array}$
\end{tabular}

$1_{\mathrm{J}}=\mathrm{Jar} ; \mathrm{CB}=$ Carinated bowl; $\mathrm{B}=$ Bottle

${ }^{2} \mathrm{R}=$ Rounded; $\mathrm{R}-\mathrm{RO}=$ Rounded and rolled out; $\mathrm{F}=$ Flaring

${ }^{3} \mathrm{G}=\mathrm{Grog} ; \mathrm{cG}=$ coarse grog; $\mathrm{fG}=$ fine grog

${ }^{4}$ See Suhm and Jelks (1962) for typological definitions of Harleton Appliqué (65-66), Ripley Engraved (127-130); Nash NeckBanded (111-112); Wilder Engraved (155-156); and Taylor Engraved (149-152). Ripley Engraved bowl-rim motifs follow Thurmond (1985:Figure 3). 


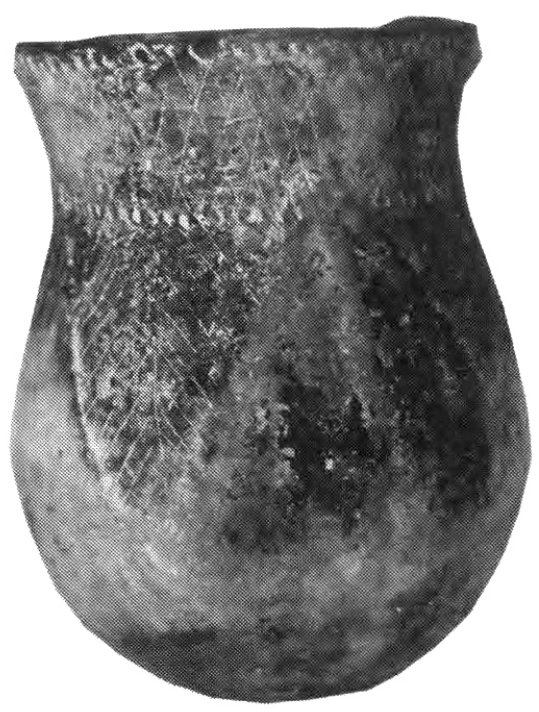

A, Burial 1, Vessel 1

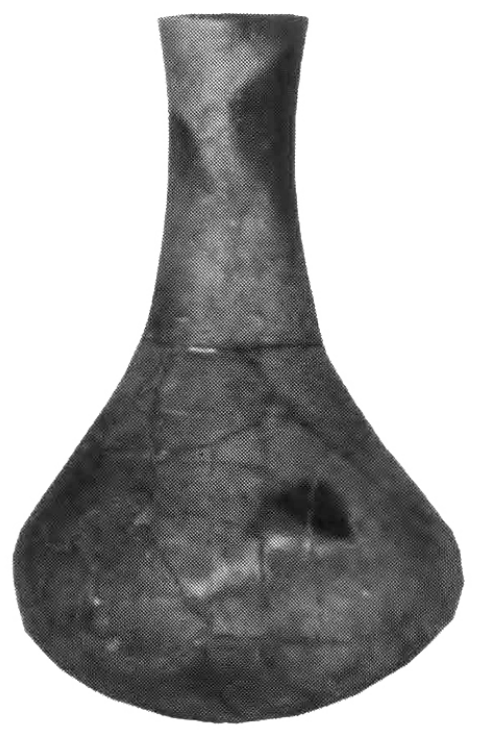

B, Burial 1, Vessel 7

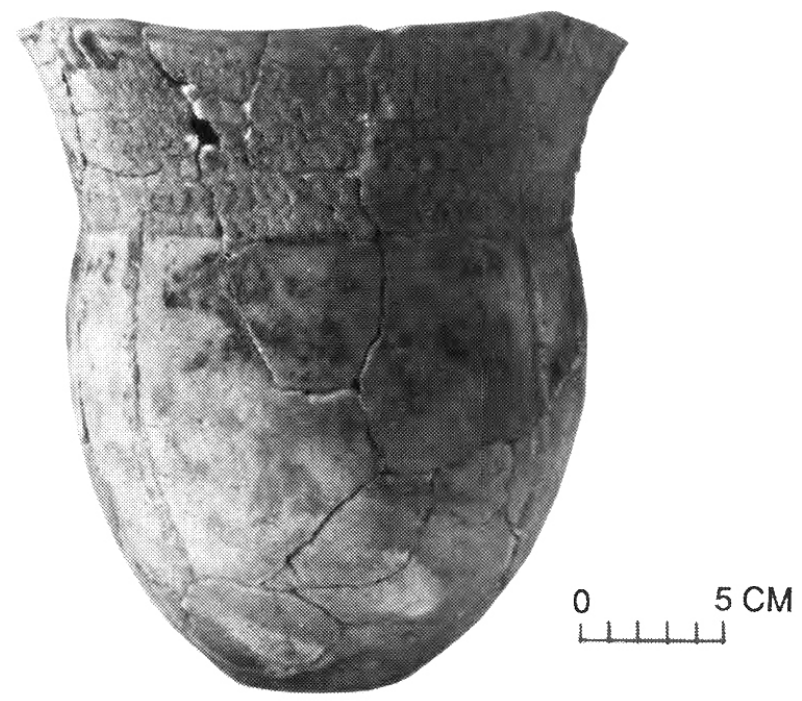

C, Burial 1, Vessel 5

Figure 15. Ceramic vessels A-G from Burial No. 1 
Perttula, Skiles, and Yates - Goldsmith Site

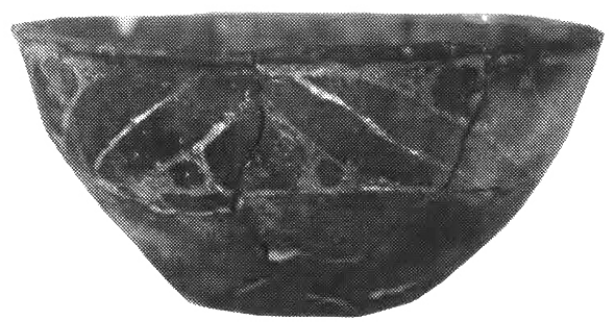

D, Burial 1, Vessel 2

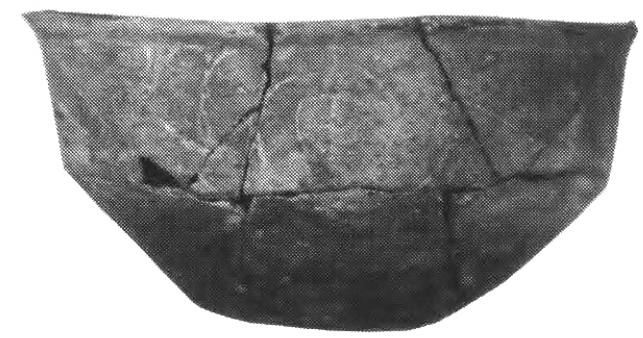

E, Burial 1, Vessel 6

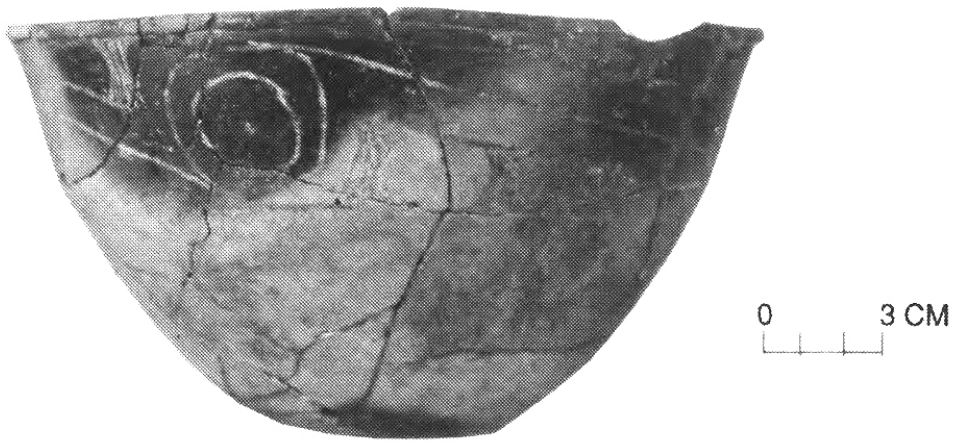

F, Burial 1, Vessel 4

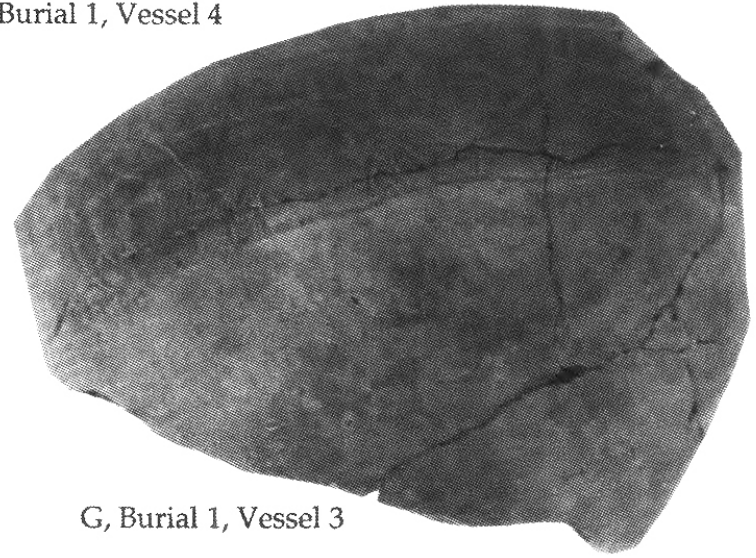

Figure 15, Continued. 


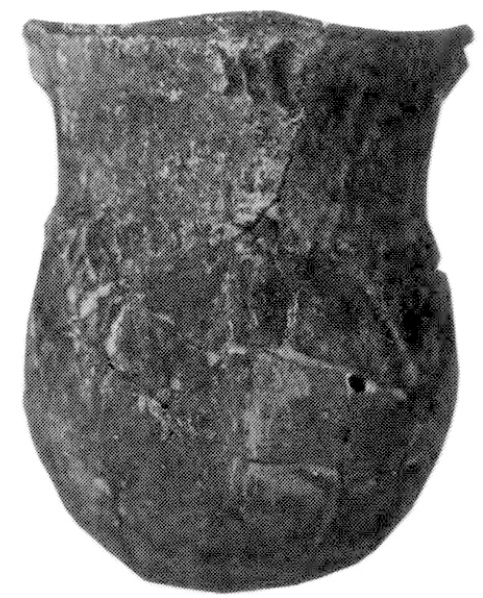

A, Burial 2, Vessel 7

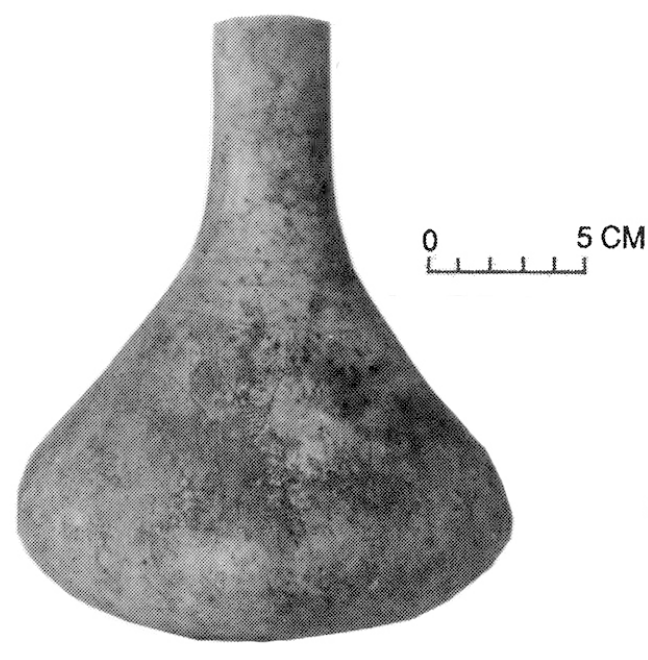

C, Burial 2, Vessel 4

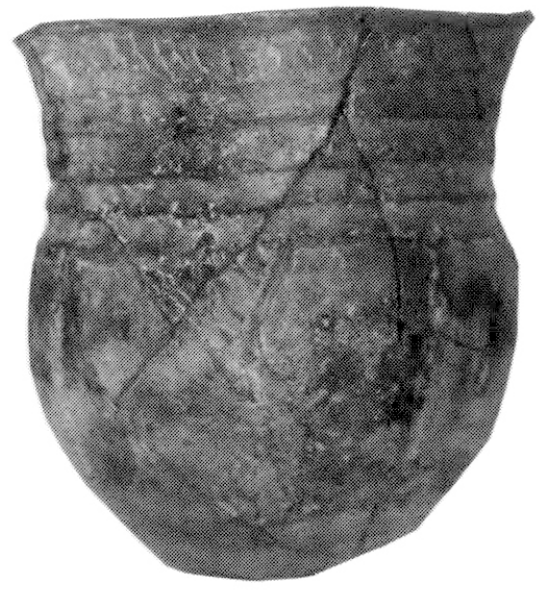

B, Burial 2, Vessel 9

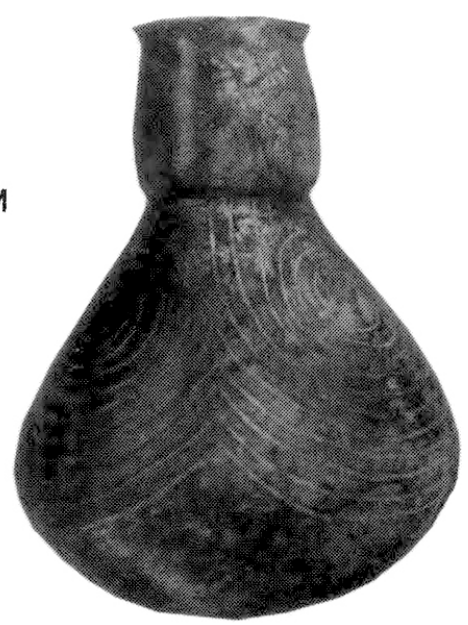

D, Burial 2, Vessel 8

Figure 16. Ceramic vessels A-G from Burial No. 2. 


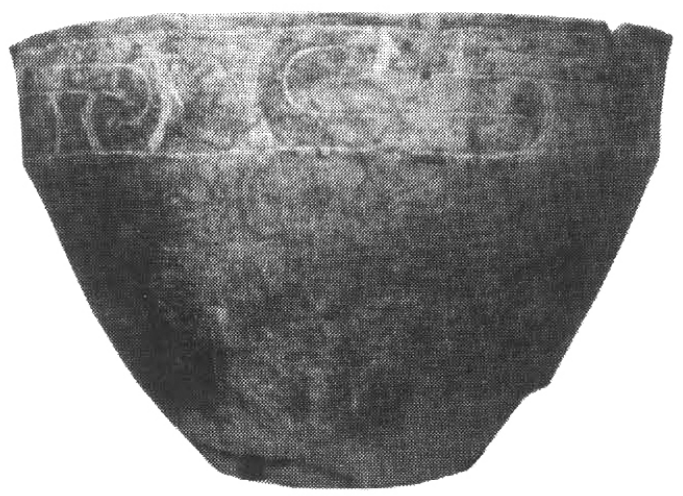

E, Burial 2, Vessel 5
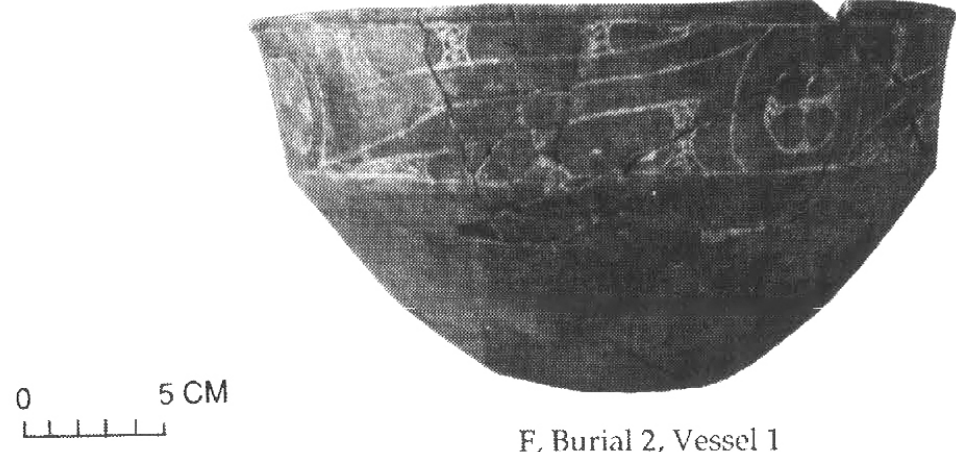

F, Burial 2, Vessel 1

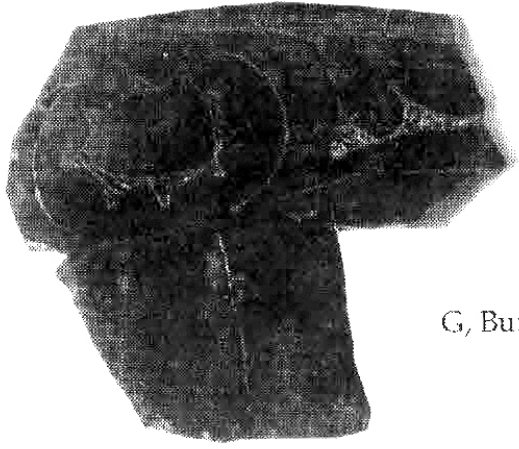

Figure 16, Continued. 


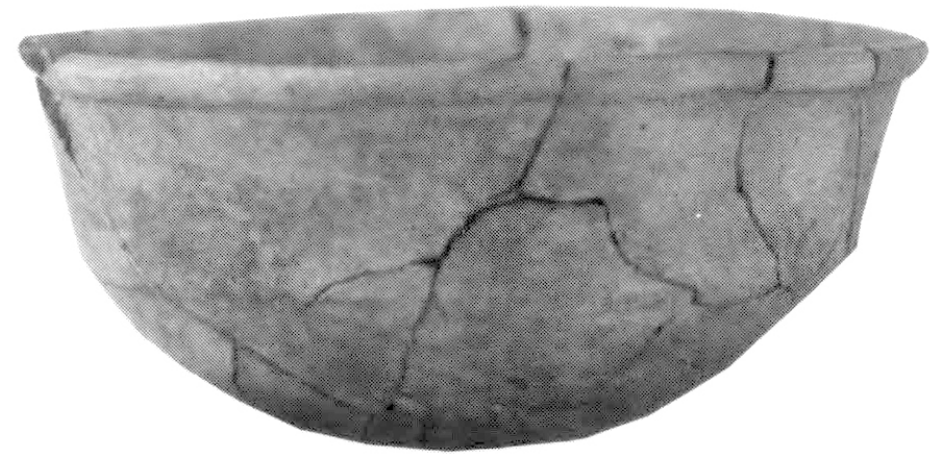

H, Burial 2, Vessel 2
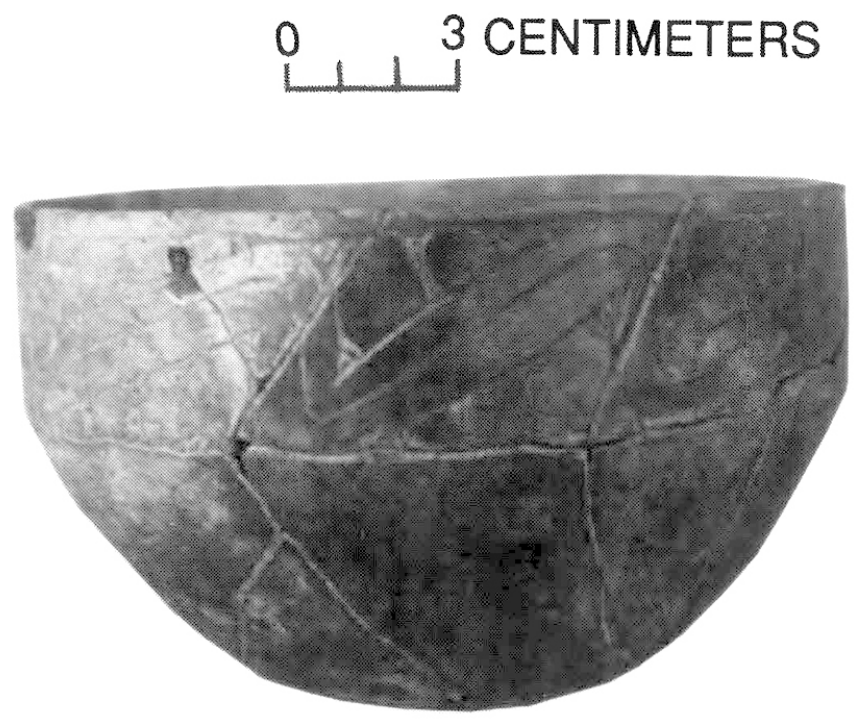

\section{I, Burial 2, Vessel 3}

Figure 16, Continued. 
A Burial 1, Vessel 4 Scroll and circle

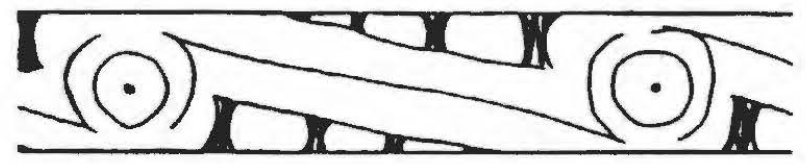

B Burial 1, Vessel 6 Scroll and circle

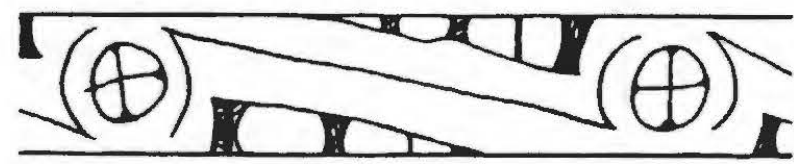

C Burial 1, Vessel 3 Scroll and circle

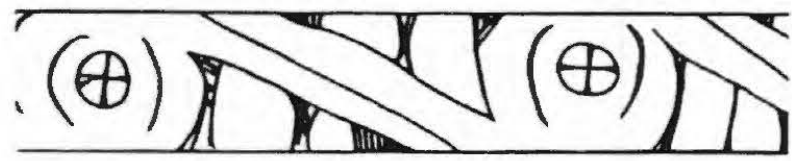

D Burial 1. Vessel 2 Nested Triangle

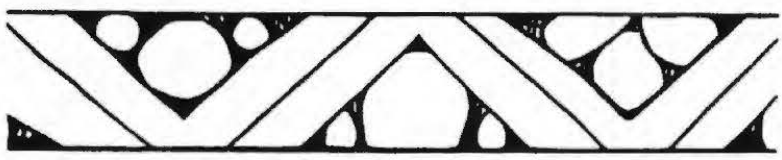

E Burial 2, Vessel 5 Scroll and circle

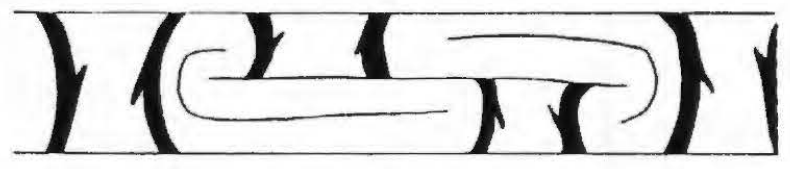

F Burial 2, Vessel 1 Scroll and circle

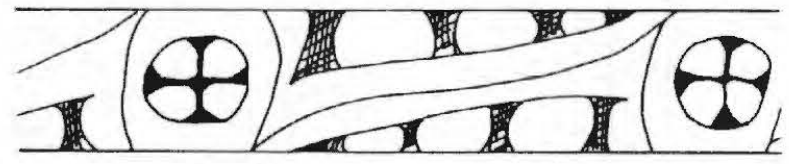

G Burial 2, Vessel 6 Scroll and circle

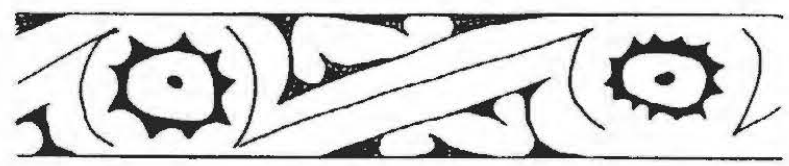

H Burial 2, Vessel 3 Continuous scroll

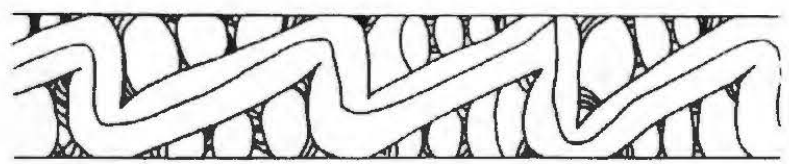

Figure 17. Motifs on Ripley Engraved carinated bowls from Burials No. 1 and 2.

Culpepper site in Hopkins County, Texas (Scurlock 1962:Figure 7a,b). At that site, Taylor Engraved occurs in association with vessels of Ripley Engraved, Womack Engraved, Simms Engraved, Hodges Engraved, and Avery-like Engraved.

The Harleton Appliqué jar (Figure 15, A) from Burial No. 1 has soot deposits and organic residue on both interior and exterior vessel surfaces, prob- 
ably from use over an open fire (e.g., Hally 1986) before it was put into the grave. The rim of the vessel has single rows of punctations at the lip and at the $\mathrm{rim} / \mathrm{body}$ juncture, separated by cross-hatched incised lines. On the body are four incised "herringbone" motifs; these are adjacent to sets of vertical appliqué that run from the rim/body juncture to near the base.

There are two distinct varieties of Nash Neck-Banded represented in the vessels from the Goldsmith site. The first has appliquéd fillets on the upper body, as well as appliquéd parentheses at the top of the rim (Figure 15, C); the second has appliquéd chevrons on the upper body. Both are found on vessels from Burial No. 2 (Figure 16, A, B), which have vertical appliquéd fillets on the bodies, and appliquéd nodes or lugs at the tops of the rims. Similar neck-banded and appliquéd vessels and sherds have been recovered at the J. H. Reese site and from several sites on Caney Creek in the Lake Fork Reservoir (Bruseth and Perttula 1981:Table 5-10).

Vessel 2 from Burial No. 2 is a polished, carinated bowl of similar shape to Ripley Engraved vessels, with a well-defined rounded and rolled lip. It is not decorated, however, except for a single engraved line on the interior of the vessel at the rim/body juncture or carination (Figure 16, H).

Short-stemmed and short-bowled elbow pipe forms have been found in Late Caddoan archeological sites in the Quitman area (Jackson 1933:71 and Plate 16). The elbow pipe from the Goldsmith site has been decorated by two horizontal engraved panels on the bowl, and by two engraved lines on the stem (Figure 18). Both sets of engraved lines were filled with white pigment, but the pigment is poorly preserved. The pipe stem is $37 \mathrm{~mm}$ long, and the bowl is $23 \mathrm{~mm}$ high. The lip profiles for both bowl and stem holes are flattened; the lips are from 3 to $5 \mathrm{~mm}$ thick. Grog temper was used as an aplastic in the sandy paste and, although weathered, the pipe appears to have been polished. The bowl diameter is about $37 \mathrm{~mm}$; the exterior stem diameter is only $25 \mathrm{~mm}$, and the interior stem hole is about $4 \mathrm{~mm}$ in diameter.

\section{Daub and Burned Clay}

Small eroded pieces of daub and burned clay were recovered from the surface of the disturbed trash midden and from the test excavations. Both categories of fired clay are relatively amorphous, but pieces identified as daub, unlike the burned clay, have stick and grass impressions. The daub is assumed to be pieces of clay-plastered wall and thatch, probably from a burned structure. The burned clay may be of the same origin, although that is difficult to ascertain without more contextual information from the site as a whole.

Only five pieces of daub and fourteen pieces of burned clay have been identified from the trash midden. Since ninety percent of these pieces come from the top $20 \mathrm{~cm}$ of the midden deposits, including the disturbed plow zone (see Table 4), any buming, and hence accumulation of daub/burned clay, took place at the end of the deposition of the midden rather than at the beginning of the occupation when the 

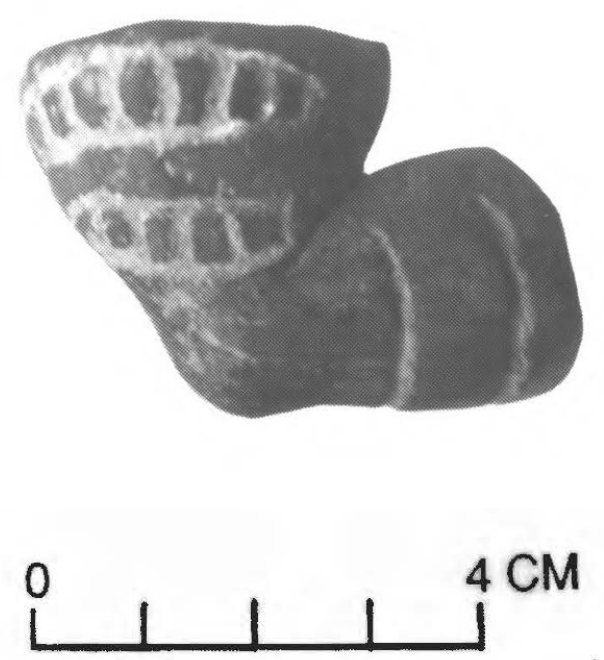

Figure 18. Elbow pipe from Burial No. 2.

midden began to accumulate. The impressed daub specimens resemble those identified from Late Caddoan Titus phase contexts at the Killebrew site, Midden A (Bruseth and Perttula 1981:98), where it seemed likely that narrow-bladed grasses were used for thatching on the house walls.

\section{Summary of the Midden}

The overall composition of the Goldsmith site trash midden ceramic assemblage compares favorably with that from the Steck site $2.5 \mathrm{~km}$ northeast (Hockensmith 1977) in the relative ranking and frequency of the decorative categories (Table 8). From this information, it is possible to infer that the Steck and Goldsmith sites are probably contemporaneous, within \pm 25 to 50 years, manifestations of a Titus phase occupation in the Dry Creek locality. Ceramic assemblages in the Caney Creek locality are different, but, because of the lack of absolute dates for the Late Caddoan Period in the Upper Sabine Basin (Perttula et al. 1987), it cannot be determined yet whether this is a result of temporal and/ or social differences (e.g., Thurmond 1985). On the basis of the stylistic motifs on Ripley Engraved in the Caney Creek locality (see Bruseth and Perttula 1981:Figure 5-7), it is suspected that these ceramic variations in vessel decorations denote different social groups that reflect generally contemporaneous Titus phase occupations. Based on the one radiocarbon date from the Steck site, it is estimated that the Goldsmith occupation took place from between A.D. 1400 at the earliest to about 1550 to 1600 at the latest. 


\section{CONCLUSIONS}

Late Caddoan Titus phase sites are common in the Wood County part of the Upper Sabine Basin, primarily in the Dry Creek and Caney Creek drainages and along Lake Fork Creek between the confluences of these two creeks (Skilcs et al. 1980:Figure 6; Thurmond 1985:Figure 6). The settlements are distributed almost exclusively along tributaries and headwater areas rather than along major streams. In the Caney Creek drainage, Titus phase sites are known at least as far north as the Attaway site (41HP15) near Como. Similar Late Caddoan settlement patterns are apparent in Harrison and Rusk counties on creeks like Hatley Creek in the South Hallsville Mine Project(LaVardera 1985), Martin Creek (Clark and Ivey 1974), and Potters Creck directly to the north (Webb et al. 1969). Thurmond (1981:Table 54) has documented settlement locations for the Titus phase in the Cypress Creek basin that also emphasized intermediate and minor-sized basins, including headwater areas adjacent to springs.

There is no apparent settlement hierarchy in the local Titus phase, although occupations at the Steck and M. W. Burks (4IWD52) sites (Pertula et al. n.d.) may represent large settlements (cf., Thurmond 1981:100). Possible substructural mounds in the Dry Creek and Lake Fork Creek basins at the J. D. Conger (4IWD8) and A. N. Vickery (41WD11) sites trenched by A. T. Jackson in the early 1930 s may date to this period, but that work yielded little cultural and stratigraphic information. If these possible substructural mounds are of Late Caddoan age, it is possible that they represent local civic-ceremonial centers like McKenzie [41WD55] (Granberry 1985 ) in the Upper Sabine Basin that date before A.D. 1500 (Story 1981:149; Thurmond 1981:Table 52).

The basic type of Titus phase site in the Three Basins subcluster is a small settlement of one to several homesteads or farmsteads. These are marked by trash and household middens that must have been deposited during an occupational episode of at most 20 to 50 years (see Good 1982). The character, extent, and content of local Late Caddoan trash middens (Table 10) reflect a basic similarity not only in the length and type of occupation, but also in the activities relating to refuse disposal at that time.

The house at the Goldsmith site was probably destroyed by the road construction, since it was probably located between the trash midden and the cemetery. It is also unfortunate that an accurate estimate of the number of burials in the cemetery cannot be made since ideally,

the relative duration of the hamlets (settlements) can be measured by the number of graves in the cemeteries and relative temporal placement of each hamlet can be determined by seriating mortuary assemblages [Shafer 1981:156].

The ecofactual remains from trash middens would contribute important subsistence information on the Titus phase if a larger, statistically reliable sample could be obtained (e.g., Grayson 1984; Jones et al. 1983). This could be accomplished 
Table 10. Comparison of Late Caddoan Trash Middens

\begin{tabular}{|c|c|c|c|c|c|c|}
\hline \multirow[b]{2}{*}{ Site } & \multirow[b]{2}{*}{$\begin{array}{c}\text { Area } \\
\left(\mathbf{m}^{2}\right)\end{array}$} & \multirow[b]{2}{*}{$\begin{array}{c}\text { Volume } \\
\left(\mathbf{m}^{3}\right)\end{array}$} & \multirow[b]{2}{*}{$\begin{array}{c}\% \\
\text { Sample }\end{array}$} & \multicolumn{3}{|c|}{ Estimated Midden Content } \\
\hline & & & & $\begin{array}{c}\text { Ceramic } \\
\text { Sherds }\end{array}$ & $\begin{array}{c}\text { Lithic } \\
\text { Artifacts }\end{array}$ & $\begin{array}{l}\text { Bone } \\
\text { Debris }\end{array}$ \\
\hline Goldsmith & 49 & 19.6 & 4.1 & 9000 & $1500^{1}$ & 3000 \\
\hline Steck & 81 & 24.0 & 22.7 & 9200 & 900 & 2500 \\
\hline $\begin{array}{l}\text { Killebrew } \\
\text { midden D }\end{array}$ & 180 & 36.10 & 5.0 & 9700 & 3900 & $t^{2}$ \\
\hline
\end{tabular}

${ }^{1}$ Counts are probably inflated because of Archaic Period occupations at the site.

${ }^{2}$ Faunal materials are not quantified in Bruseth and Pertula (1981).

with the excavation of about 20 to 40 percent of the midden $\left(4\right.$ to $\left.8 \mathrm{~m}^{3}\right)$ if the faunal densities from our work at the Goldsmith site are representative.

Subsistence remains with interpretive significance for the Titus phase are still limited to the Steck site (Perttula et al. 1983), although well-preserved remains are known at several other sites that have as yet received little professional attention. Floral evidence suggests that the tropical cultigen maize (Zea mays L.) is a dietary staple, and beans (Phaseolus vulgaris) were also an important food source. Nuts and seeds available in local environmental settings were also gathered, but may have been of less importance in the Titus phase than they were between about A.D. 1000 and 1400 (Crane 1982; Perttula and Bruseth 1983). Vertebrate species identified from the trash midden at the Steck site include deer, turkey, cottontail, jackrabbit, squirrel, and beaver, as well as several dog burials. Turtle and fish remains were also present but were relatively uncommon compared to the mammals and birds (Perttula et al. 1983); deer and turkey were the dominant species at the Steck site.

The Late Caddoan archeological sites in the Dry Creek and Caney Creek drainages of the Lake Fork basin have been included in the recently defined Cypress Cluster, which is thought to be

the archeological manifestation of a series of social groups banded together in a socio-political structure analogous to and at least partially contemporaneous with that of the Hasinai to the south and the Kadohadacho to the northeast. Four subclusters . . . are believed to represent the individual component groups comprising this affil iated group [Thurmond 1985: 196].

The Three Basins subcluster comprises Titus phase occupations on Caney and Dry creeks in the Upper Sabine Rjver Basin, and headwater areas of Litule Cypress, 
Big Cypress, and White Oak creeks. More recently, sites attributable to the Three Basins subcluster have been identified in the Big Sandy Creck valley (Pertiula et al. 1986). The suggested dating of the Cypress Cluster to between A.D. 1600 and 1700 (Thurmond 1985:192) is as yet untested by absolute dating methods. A corrected date of A.D. $1470 \pm 80$ from the Steck site may mean that the Three Basins subcluster developed at an earlier date than is consistent with current chronological frameworks for the Cypress Cluster. Obtaining thermoluminescence and radiocarbon dates from sites such as Goldsmith or Steck is vital to the acquisition of new information on the development of the Cypress Cluster and the Titus phase. The primary units of analysis - the hamlet cemeteries-limit to some extent the precision and reliability of diachronic analyses in the Titus phase. The likelihood or possibility of frequent shifting of seulements on a generational basis suggests that a large number of sites would be identified within the four subclusters that are actually sequent to (rather than contemporaneous with) other known sites. Synchroneity between and within subclusters is much more difficult to demonstrate with a series of archeological components in this situation than are intraphase diachronic changes.

Nevertheless, the definition of the Cypress Cluster, an archeological unit with specific implications for the recognition of sociopolitical groupings, indicates that Late Caddoan sites in the Upper Sabine River Basin can be studied within an analytical framework superseding basic settlement patteming questions. This is because recognition of the Cypress Cluster is an initial attempt in East Texas archeology to relate archeological units to regionally meaningful sociocultural variables that have specific archeological implications (e.g., Thurmond 1985). If differences between the Dry Creek and Caney Creek localities have more than temporal significance, that is, if they represent archeological manifestations of contemporaneous constituent groups (Story and Creel 1982) within the Three Basin subcluster, sites such as Goldsmith will be important contextual units for investigation in further studies of Late Caddoan prehistory. Their short occupation spans, their potential for developing close-order and fine-scale seriations, and the possibility of obtaining economic information at an analytically useful level (the individual farmstead or homestead), are ideal for investigating intraregional and interregional settlement, sociopolitical organization, and adaptive variability between about A.D. 1400 and 1700. The individual farmstead or homestead is the most common type of Late Caddoan settlement in the Upper Sabine Basin, but one that until recently has received little professional archeological scrutiny. Hypotheses about the formation, development, and eventual disintegration of Late Caddoan sociopolitical groupingsin East Texas can be evaluated, where appropriate, with the type of Late Caddoan archeological record known to exist at sites such as Goldsmith throughout the Dry and Caney Creek localities.

Attempting to model archeological contemporaneity for the Titus phase as a whole will certainly require a more comprehensive chronological data basc than now exists if sociopolitical interpretations and considerations of adaptation are to be seriously considered, for as Story (1981:152) has pointed out, 
certainly the Caddoan area is neither environmentally or culturally homogenous. Different processes could have been in operation simultaneously and it must be established, not assumed, that the sequence of cultural change in one locale applies to another.

We hope our research at the Goldsmith site will contribute to a better understanding of the Three Basins subcluster of the Titus phase in the Dry Creek basin of East Tcxas, and serve to initiate more systematic and long-term rescarch on Late Caddoan archeology in the Upper Sabine Basin and throughout East Texas.

\section{ACKNOWLEDGEMENTS}

We arc gratcful for the cooperation and assistance of several people during the work at the Goldsmith site. The owners of the site, the Goldsmith family, permitted access and sharcd our concern that the site be protected if possible. Wc especially thank Gene Goldsmith, Dr. J. Paul Goldsmith, and H. B. Goldsmith. Jamcs E. Bruseth helped with the access negotiations and facilitated the initial work. He also provided information about the Steck and Pine Trec Farm site ceramic assemblages that proved useful in the Goldsmith analysis. Mr. Craig Lacy and Mr. Robert Turbeville assisted Skiles in gathering information about the site after its initial exposure, and Ms. Pcggy Trachte provided support during the excavations in the poison-ivy-covered midden. We also thank Mr. Gerald Blow for drafting the maps. Dr. C. Reid Ferring helped considerably in the editing of the manuscript, and in improving its structure, but we remain responsible for the content and final form of the paper.

\section{REFERENCES CITED}

Aitken, M. J.

1985 Thermoluminescence Dating. Academic Press, London.

Albert, L. E.

1981 Ferndale Bog and Natural Lakc: Five Thousand Years of Environmental Change in Southeastern Oklahoma. Studies in Oklahoma's Past No. 7. Oklahoma Archeological Survey, Norman.

Arbingast, S. A., L. G. Kennamer, R. H. Ryan, J. R. Buchanan, W. L. Hezlap, T. G. Jordan, C. T. Granger, and C. P. Zlatkovich.

1973 Allas of Texas. Burcau of Business Research, The University of Texas at Austin.

Banks, L. D.

1984 Lithic Resources and Quarries. In: Prehistory of Oklahoma, ediled by R. E. Bell, pp. 65-95. Academic Press, New York. 
Banks, L. D., and J. Winter

1975 The Bentsen-Clark Site, Red River County, Texas: Preliminary Report. Texas Archeological Society, Special Publication No. 2.

Barnes, V. E. (Project Director)

1965 Geologic Atlas of Texas, Tyler Sheet. Bureau of Economic Geology. The University of Texas at Austin.

Bell, M.

1981 The Alex Justiss Site: A Caddoan Cemetery in Titus County, Texas. Texas State Department of Highways and Public Transportation Highway Design Division Publications in Archaeology Report No. 21. Austin.

Blair, W. F.

1950 The Biotic Provinces of Texas. Texas Journal of Science 2:93-117.

Bruseth, J. E., and T. K. Pertrula

1980 Archaeological Research at Lake Fork Reservair: Excavations at the Howle Site and Site Testing. Archaeology Research Program, Southem Methodist University, Dallas.

1981 Prehistoric Settlement Patterns at Lake Fork Reservoir. Texas Ansiquities Permit Series, Report No. 2. Texas Antiquities Committee, Austin, and Southem Methodist University, Dallas.

Bruseth, J. E., J. T. Bagot, K. M. Banks, and M. A. McKinley

1977 Archaeological Research at Lake Fork Reservoir: Site Inventory and Assessment. Southern Methodist University. Archaeology Research Program, Research Report No. 87. Dallas.

Bryant, V. M., and R. G. Holloway

1985 A Late Quaternary Paleoenvironmental Record of Texas: An Overview of the Pollen Evidence. In: Pollen Records of Lase-Quaternary North American Sediments, edited by V. M. Bryant and R. G. Holloway, pp. 39-70. American Association of Stratigraphic Palynologists Foundation, Dallas.

Clark, J. W., and J. E. Ivey

1974 Archeological and Historical Investigations at Martin Lake, Rusk and Panola Counties, Texas. The University of Texas at Austin, Texas Archeological Survey, Research Report 32.

Crane, C. J.

1982 Plant Utilization at Spoonbill, an Early Caddo Site in Northeast Texas. Midconsinental Journal of Archaeology 7:81-97.

Espey, Huston and Associates, Inc.

1984 The Cultural Resources Investigations at the Henry W. Pirkey Power Plant and South Hallsville Lignite Mine Transportive Systems Re-Route, Harrison County, Texas. Espey, Huston and Associates, Inc., Document No. 83434, Austin. 
Ferring, C. R.

1969 Pecked and Ground Stone. In: Archaeological Investigations at the Sam Kaufman Site, Red River County, Texas, edited by S. A. Skinner, R. K. Harris, and K. M. Anderson. Southern Methodist University, Contributions in Anthropology No. 5, Dallas.

Ferring, C. R., and T. K. Pertrula

1987 Defining the Provenance of Red-Slipped Pottery from Texas and Oklahoma by Petrographic Methods. Journal of Archaeological Science 14:437-456.

Flores, D. L. (editor)

1985 Journal of an Indian Trader: Anthony Glass and the Texas Trading Frontier, 1790-1810. Texas A\&M University Press, College Station.

Good, C. E.

1982 Analysis of Structures, Burials, and other Cultural Features. In: The Deshazo Site, Nacogdoches County, Texas, Volume I, edited by D. A. Story, pp. 51-112. Texas Antiquities Permit Series, No. 7. Texas Antiquities Committee, Austin.

Gould, F. W.

1969 Texas Plants: A Checklist and Ecological Study. Texas A\&M University, Miscellaneous Papers, College Station.

Gramberry, D.

1985 Eight C-14 Dates from the McKenzie Mound, 41WD55. The Record, Newsletter of the Dallas Archaeological Society 40(2):4-9.

Grayson, D. K.

1984 Quantilative Zooarchaeology. Academic Press, New York.

Hall, S. A.

1982 Late Holocene Paleoecology of the Southern Plains. Quaternary Research 17:391-407.

Hally, D. J.

1986 The Identification of Vessel Function: A Case Study from Northwest Georgia. American Antiquity 51:267-293.

Hockensmith, C. L.

1977 The Steck Site: A Titus Focus Midden, Wood County, Texas. Paper presented at the 1977 Caddo Conference, Natchitoches, Louisiana.

Holloway, R. G.

1987 Pollen Analysis of Sediment Core from Buck Creek Marsh, Wood County, Texas. In: Introduction to the Richland Creek Archaeological Project, edited by J. E. Bruseth and R. W. Moir. Appendix A, Volume I of the Richland Creek Technical Series. Archaeology Research Program, Southem Methodist University, Dallas. 
Jackson, A. T.

1933 Some Pipes of East Texas. Bullet in of the Texas Archeological and Paleonsological Society 5:69-86.

Johnson, L., Jr.

1962 The Yarbrough and Miller Sites of Northeastern Texas, with a Preliminary Definition of the LaHarpe Aspect. Bulletin of the Texas Archeological Society 31:141- 284 .

Jones, G. T., D. K. Grayson, and C. Beck

1983 Artifact Class Richness and Sample Size in Archaeological Surface Assemblages. In: Lulu Linear Punctated: Essays in Honor of George Irving Quimby, edited by R. C. Dumnell and D. K. Grayson. University of Michigan, Anthropological Papers of the Musewn of Anthropology, No. 72:55-73, Ann Arbor.

Küchler, A. W.

1964 Potential Natural Vegetation of the Conterminous United States. American Geographical Society Special Publication 36. New York.

LaVardera, L. T.

1985 Backhoe Trenching at 4IHS282, South Hallsville Project, Harrison County, Texas. North American Consultants, Inc., Dallas.

Lorrain, D.

1967 Animal remains. In: The Gilbert Site, edited by E. B. Jelks. Bulletin of the Texas Archaeological Society 37:225-243.

Marietra, K. L., and E. S. Nixon

1984 Vegetation of an Open, Prairie-Like Community in Eastern Texas. Texas Journal of Science 36:25-34.

Nixon, E. S., R. L. Ehrhart, S. A. Jasper, J. S. Neck, and J. R. Ward

1983 Woody, Streamside Vegetation of Prairie Creek in East Tex as. Texas Journal of Science 35:205-213.

Pertula, T. K.

1984 Patterns of Prehistoric Lithic Raw Material Utilization in the Caddoan Area: The Western Gulf Coastal Plain. In: Prehistoric Chert Exploitation-Studies from the Midcontinent, edited by B. M. Butler and E. E. May. Southern Illinois University-Carbondale, Center for Archaeological Investigations, Occasional Paper 2:129-148.

Pertula, T. K., and J. E. Bruseth

1983 Early Caddoan Subsistence Strategies, Sabine River Basin, East Tex as. Plains Anthropologist 28:9-21.

Pertula, T. K., B. D. Skiles, B. C. Yates, and J. E. Bruseth

n.d. Archaeological Investigations at the Burks Site (41WD52), a Late Caddoan Occupation in Wood County, Texas. MS in preparation. 
Perttula, T. K., C. J. Crane, and J. E. Brusech

1983 A Consideration of CaddoanSubsistence.Southeastern Archaeology 1:89-102.

Perttula, T. K., B. D. Skiles, M. B. Collins, M. C. Trachte, and F. Valdez, Jr.

1986 "This Everlasting Sand Bed": Cultural Resources Investigations at the Texas Big Sandy Project, Wood and Upshur Counties, Texas. Prewitt and Associates, Inc., Reports of Investigations No. 52, Austin.

Pertula, T. K., R. R. Turbeville, and B. D. Skiles

1987 New Thermoluminescence and Radiocarbon Dates from the Upper Sabine River Basin, East Texas. Texas Archeology 31(2):7-9.

Reese, M. M.

1931 Report on Miscellaneous Sites in Wood County, Texas. MS on file, Texas Archeological Research Laboratory, Austin.

Reid, K. C., and J. A. Artz

1984 Hunters of the Forest Edge: Culture, Time, and Process in the Little Caney Basin. Oklahoma Archeological Survey, Studies on Oklahoma's Past No. 13. Norman.

Rose, J. C.

1984 Bioarchaeology of the Cedar Grove Site. In: Cedar Grove: An Interdisciplinary Investigation of a Late Caddo Farmstead in the Red River Valley, edited by N. L. Trubowitz. Arkansas Archeological Survey, Research Series No. 23:227_ 256. Fayetueville.

Schambach, F. F.

1982 An Outline of Fourche Maline Culture in Southwest Arkensas. In: Arkansas Archeology in Review, edited by N. L. Trubowitz and M. D. Jeter. Arkansas Archeological Survey, Research Series No. 15:132-197. Fayetteville.

Scurlock, J. D.

1962 The Culpepper Site, A Late Fulton Aspect Site in Northeast Texas. Bulletin of the Texas Archeological Society 32:285-316.

Shafer, H. J.

1981 Archaeological Investigations at the Atraway Site, Henderson County, Texas. Bulletin of the Texas Archeological Saciety 52:147-179.

Skiles, B. D., J. E. Bruseth, and T. K. Pertrula

1980 A Synthesis of the Upper Sabine River Basin Culture History. The Record, Newsletter of the Dallas Archacolog ical Society 36(1):1-12.

Stahle, D. W., E. R. Cook, and J. W. C. White

1985 Tree-Ring Dating of Baldcypress and the Potential for Millennia-Long Chronologies in the Southesst. American Antiquity 50:796-802. 
Stahle, D. W., M. K. Cleaveland, and J. G. Hehr

1985 A 450-Year Drought Roconstruction for Arkansas, United States. Nafure 316:530-532.

Steponaitis, V.P.

1984 Technological Studies of Prehistoric Pottery from Alabama: Physical Properties and Vessel Function. In: The Many Dimensions of Pottery: Ceramics in Archaeology and Anthropology, edited by S. E. Van Der Leeuw and A. C. Pritchard, pp. 79-127. Universiteit van Amsterdam, Amsterdam.

Story, D. A.

1978 Some Comments on Anthropological Studies Conceming the Caddo. In: Texas Archeology: Essays Honoring R. King Harris, edited by K. D. House, pp. 4668. Southern Methodist University Press, Dallas.

1981 An Overview of the Archaeology of East Texas. Plains Anthropologist 26:139156.

1985 Adaptive Strategies of Archaic Cultures of the West Gulf Coastal Plain. In; Prehistoric Food Production in North America, edited by R. I. Ford. University of Michigan, Anthropological Papers of the Museum of Anthropology, No. 75:19-56. Amn Arbor.

Story, D. A., and D. Creel

1982 The Cultural Setting. In: The Deshazo Site, Nacogdoches County, Texas, Volume I, edited by D. A. Story, pp. 20-34. Texas Antiquities Permit Series No. 7. Texas Antiquities Committee, Austin.

Suhm, D. A., and E. B. Jelks

1962 Handbook of Texas Archeology: Type Descriptions. Texas Archeological Sociery Special Publication No. 1 and Texas Memorial Museum Special Publication No. 4.

Suhm, D. A., A. D. Krieger, and E. B Jelks

1954 An Introductory Handbook of Texas Archeology. Bulletin of the Texas Archeological Society 25.

Swanton, J. R.

1942 Source Material on the History and Ethnology of the Caddo Indians. Bureau of American Ethnology Bulletin 132. Washington, D.C.

\section{Texas Almanac}

1986 A. H. Belo Corporation, Dallas.

Thurmond, J. P.

1981 Archeology of the Cypress Creek Drainage Basin, Northeastern Texas and Northwestern Louisiana. Master's thesis, Department of Anthropology, The University of Texas at Austin.

1985 Late Caddoan Social Group Identification and Sociopolitical Organization in the Upper Cypress Basin and its Vicinity, Northeastern Texas. Bulletin of the Texas Archeological Society 54:185-200. 
Tumer, R. L.

1978 The Tuck Carpenter Site and its Relation to Other Sites within the Titus Focus. Bulletin of the Texas Archeological Sociery 49:1-110.

U.S. Army Corps of Engineers, Fort Worth District

1975 Carl L. Estes Lake, Sabine River, Texas: Draft Environmental Statement. U.S. Amny Corps of Engineers, Fort Worth District.

Webb, C. H.

1978 Changing Archaeological Methods and Theory in the Trans-Mississippi South. In: Texas Archeology: Essays Honoring R. King Harris, edited by K. D. House, pp. 19-45. Southem Methodist University Press, Dallas.

Webb, C. H., F. E. Murphey, W. G. Ellis, and H. R. Green

1969 The Resch Site, 41HS16, Harrison County, Texas. Bulletin of the Texas Archeological Sociery 40:3-106.

Wilson, A. M., and A. T. Jackson

1930 Reconnaissance in Wood County, Texas, August 10 to 24, 1930: Field Notes. MS on file, Tex as Archeological Research Laboratory, The University of Texas at Austin.

Yates, B. C.

1986 Vertebrate Faunal Remains. In: French-Indian Interaction at an 18th Century Frontier Post: The Roseborough Lake Site, Bowie County, Texas by Kathleen Gilmore. North Texas State University, Institute of Applied Sciences, Contributions in Archaeology No. 3:107-131, Denton. 


\title{
Another Look at an Eighteenth-Century Archaeological Site in Wood County, Texas
}

\author{
Timothy K. Perttula and Bob D. Skiles*
}

\begin{abstract}
$\mathbf{T}$ ile French presencf in East Texas during the kigiltfenth century is less well known from an archaeological or archival standpoint than is the Spanish. Although it is known that the French maintained several trading establishments within this part of the state, concrete evidence of these places is presently lacking. Archaeological sites that are the material remains of these trading establishments offer the best, and perhaps the last, remaining opportunities to understand and assess the mutual effects of acculturation and adaptation on French entrepreneurs and native groups such as the Caddo and Wichita living in the area.

If the eighteenth-century site known as the Woldert site is the location of the French trading post called Lc Dout, the site is especially important to future historical and scientific research dealing with European-Indian contact and interaction. If, on the other hand, the Woldert site represents an aboriginal encampment occupied after initial European settlement and exploration, study of the archaeological record provides an excellent opportunity to address how Caddoan or Wichita societies changed because of their dealings with the French and Spanish. Whichever is the case, the Woldert locality offers rich archacological, ethnographic, and archival evidence from which to study processes of culture change and thereby gain a clearer and more detailcd perspective on Indian-European interaction and adaptation in eighteenth-century 'Texas.
\end{abstract}

The Upper Sabine Basin of East Texas in the eighteenth century was part of the area between the Upper Angelina and the Red River de-

Friends of Northeast Texas Archaeology, Special Publication No. 1 (1995) 
scribed by Herbert E. Bolton as uninhabited territory.' The original inhabitants were probably Caddoan-speaking groups, agricultural peoples who had lived in the area for several thousand years before the Europeans arrived in Texas. ${ }^{2}$ By the time French and Spanish settlers began to colonize the Red River Valley and parts of East I'exas circa $1690,{ }^{3}$ these agricultural tribes were organized into entities known as confederacies. ${ }^{4}$ The principal confederacies were the Kadohadacho and I Iasinai. ${ }^{5}$ They lived on the Red River and on the Neches and $\mathrm{An}$ gelina rivers, respectively, in East Texas and adjoining areas of Arkansas, Louisiana, and Oklahoma.

Except for scattered archival and archaeological evidence, little is known about what happened to the Caddoan groups who had lived in the Upper Sabine Basin before $1690{ }^{6}$ When Anglo-American pioneer settlers reached this part of the East Texas frontier about ${ }_{1} 8_{40}$, the only Indian groups living there were Shawnee, Delaware, Clooctaw, Quapaw, and Cherokee groups who had originally resided east of the Mississippi River. ${ }^{7}$ Southern Wichita-speaking groups such as the Tawakoni, Taovayas, and Yscani had moved into the Upper Sabine Basin from the Arkansas River Valley in the middle of the eighteenth cen-

\footnotetext{
'Hcrbert K. Bolton, "The Native Tribes about the East Texas Missions," Quarterly of the Texas State Historical Association, XI (Apr., 1908), 249-276.

${ }^{2}$ W[illiam] W. Newcomb, The Indians of Texas: From Prehistoric to Modern Times (Austin: University of Texas Press, 1961); John R. Swanton, Source Material on the History and Ethnology of the Caddo Indians, Bulletin 1.32 (Washington, I).C.: Smithsouian Institution, Bureau of American Ethnology, 1942).

"Kathleen [K.] Gilmore, "Spanish Colonial Settlements in Texas," in Texas Archeology: Essays Honoring R. King Harris, ed. Kurt D. House (Dallas: SMU Press, 1978), 132-145.

${ }^{4}$ The term confederacy refers to two or more tribes or constituent groups joined together as equal and autonomous entities and sharing a common political organization. Archaeological and ethnohistorical data suggest that confederacies as political alliances of tribes are not particularly applicable beforc about 1700 , and their formation may have been the result of both European and Osage depredations. See Hiram F. Gregory, "Eighteenth-Century Caddoan Archaeology; A Study in Models and Interpretation" (Ph.D. diss., Southern Methodist University, 1973); Dec Ann Story, "Some Comments on Anthropological Studies Concerning the Caddn," in Texas Archeology. 51-52: Garrick A. Bailcy, Changes in Osage Social Organization 1673-1906, Anthropological Papers No. 5, University of Oregon (Eugene: University of Oregon Press, 1973), 10. According to Swanton (Source Material on the History and Ethnology of the Caddo Indians, 8), "the tribes ... did not live in groups which maintained the same constituent elements unchanged from geiteration to generation."

${ }^{5}$ Ibid.

${ }^{6}$ Herbert Eugene Bolton. Texas in the Middle Eightepnth Century: Studies in Spanish Colonial IIistory and Administration (Berkeley: University of California Press, 1915); sclected articles by Thomas N. Campbell on Indians in Texas in Walter Prescott Webb, H. Bailey Carroll, and Eldon Stephen Branda (eds.), The Handbonk of 'Texas ( 3 vols.; Austin: Texas State Historical Association, 1976), I11, 28, 132, 143, 374, 629; Buddy Calvin Jones, "The Kinsloe Focus: A Study of Seven I listoric Caddoan Sites in Northeast 'lexas" (M.A. thesis, University of Oklahoma, 1968 ).

"W. A. Woldert, "East Texas," 5-vol. 1932 transcript, Woldert Papers (Tyler l'ublic Library, Tyler, Tex.); Jean Louis Berlandier, The Indians of Texas in 1830 , ed. John C. Ewers, trans. l'atricia Reading Ierlercq (Washington, D.C.: Smithonian Institutiou Press, ig6g).
} 

before the first permanent settlement of the area by Anglo-Americans.

Archaeological and ethnohistoric research has been widely carried out in East Texas, notably by scholars such as Lathel F. Duffield, Edward B. Jelks, Leroy Johnson, Jr., Kathleen Gilmore, Dee Ann Story, R.' King Harris and associates, Don G. Wyckoff, Elizabeth John, and Mildred Mott Wedel. The aim of this research has been to understand the heritage and patterns of culture change in aboriginal Caddoan and Wichita groups during the historic period $1685-1821 .{ }^{9}$ This work has sought to identify specific Indian archaeological sites that were occupied after 1685 , then to link the site and its archaeological record with aboriginal groups described in Spanish, French, and American archival and documentary sources. ${ }^{10}$ This linkage between the historic

\footnotetext{
${ }^{8}$ Elizabeth A. H. John, Storms Brewed in Other Men's Worlds: The Confrontation of Indians, Spanish, and French in the Southwest, 1540-1795 (College Station: Texas A\&M University Press, 1975); Mildred M. Wedel, "The Wichita Indians in the Arkansas River Basin," in Plains Indian Studies: A Collection of Essays in Honor of John C. Ewers and Waldo R. Wedel, Smithsonian Contributions in Anthropology No. 3o, ed. Doug H. Ubelaker and Herman J. Viola (Washington, D.C.: Smithsonian Institution Press, 1981), $118-133$.

${ }^{9}$ Lathel F. Dufheld and Edward B. Jelks, The Pearson Site: A Historic Indian Site in Iron Bridge Reservoir, Rains County, Texas, Archaeology Series, No. 4 (Austin: University of Texas, Dept. of Anthropology, 1961); Daniel E. Fox, Traces of Texas History: Archeological Evidence of the Past 450 Years (San Antonio: Corona Publishing Co., 1983); Kathleen K. Gilmore, Caddoan Interaction in the Neches Valley, Texas (Lincoln, Neb.: J \& L Reprint Co., 1983); Kathleen K. Gilmore, FrenchIndian Interaction at an Eighteenth-Century Frontier Post: The Roseborough Lake Site, Bounie Coninty, Texas, Contributions in Archaeology No. 3 (Denton: North Texas State University, Institute of Applied Sciences, 1986); R. K[ing] Harris, Inus Marie Harris, Jay C. Blaine, and Jerrylee Blaine, "A Preliminary Archeological and Documentary Study of the Womack Site, Lamar County, Texas," Bulletin of the Texas Archeological Society, XXXVI (1965), 287-363; Edward B. Jelks (ed.), "The Gilbert Site: A Norteño Focus Site in Northeastern Texas," Bulletin of the Texas Archeological Society, XXXVII (1967); Leroy Johnson, Jr., and Edward B. Jelks, "The TawakoniYscani Village, 1760: A Study in Archeological Site Identification," Texas Journal of Science, X (Dec. 1958), 405-422; M. P. Miroir, R. King Harris, Jay C. Blaine, and Janson McVay, "Bénard de la Harpe and the Nassonite Post," Bulletin of the Texas Archeological Society, XLIV (1973), 113-167; 'Timothy K. Perttula and Ann F. Ramenofsky, "An Archaeological Model of Caddoan Culture Change: The Historic Period," Southeastern Archaeological Conference Bulletin, XXIV (1981), 13-15; Dee Ann Story (ed.), The Deshazo Site, Nacogdoches County, Texas, Permit Series No. 7 (Austin: Texas Antiquities Committec, 1982); Don G. Wyckoff and Timothy G. Baugh, "Early Historic Hasinai Elites: A Model for the Material Culture of Governing Elites," Midcontinental Journal of Archaeology, V (1980), 225-283.

${ }^{10}$ The main archival and documentary sources are Spanish and French archival sources for the colonies of Spanish Texas $(1717-1836)$, Spanish Louisiana $(1763-1803)$, and French Louisiana $\left(1699-176_{3}\right)$. The main sources of French archival records are the Archives des Colonies Series C 1 $13 a, C 19 b$, and $C_{13 c}$, letters written to the ministry in France from the colony in Louisiana, and memoirs and projects from the Louisiana posts. See D. Rowland, A. G. Sanders, and P. K. Galloway (trans. and eds.), Mississippi Provincial Archives: French Dominion, IV, $1739-1748$, and V, $1749-1763$ (5 vols.; Baton Rouge: Louisiana State University Press, 1984). The two main Spanish archival sources are the Archivo General de Indias and the Archivo General y Puhlico de la Nacion. The Barker Texas History Center of the University of Texas at Austin has extensive transcriptions of documents preserved in these archives as well as other archival materials in the Bexar Archives. See Chester V. Kielman, The University of Texas Archives: A Guide to the Historical Manuscripts Collections in the University of Texas Library (Austin: University of Texas Press, 1967 ). Other archival sources of concern to ethnohistoric research in
} 
and archaeological records" is explored here with a reexamination of the eighteenth-century site now named the Woldert site. ${ }^{12}$ Known since the 1870 , and described in this journal in $195^{2},{ }^{13}$ the site has generally been overlooked since it was first discovered.

The Woldert site is intriguing for several reasons. First, it is located north of the Sabine River and near to known historic eighteenthcentury Caddoan and Wichita settlements. Second, the large quantity of European manufactured goods found there suggests the existence of a sizable encampment. Finally, available archival information describes one or two eighteenth-century French "factories" or trading posts that were located in the vicinity. ${ }^{1 / 2}$ Thus, the site could conceivably represent an important aboriginal settlement as well as a French trading establishment set up to deal in the deer and peltry trade. ${ }^{15}$

East Texas include the Natchitoches Archives, the Records of the Cabildo (the Spanish administrative bureaucracy in Louisiana) availahle at the New Orleans Public Lihrary in New Orleans and the Spanish Governor Dispatches in the Howard-Tilton Memorial Lihrary at Tulane University in New Orleans. See A. O. Hebert. "Resources in Louisiana Depositories for the Study of Spanish Activities in Louisiana," in The Spanish in the Mississippi Valley, 1762-1804, ed. J. McDermott (Urhana, Ill.: University of Illinois Press, 1965 ), 26-37. The Spanish documents deal with asperts of military and economic policy involving Indian, American, and French groups under Spanish Louisiand administration $\left(1763-180_{3}\right)$. The Natchituches Archives are availahle at the Natchitoches Purish Courthouse in Natchitoches, Louisiana, hut have not been systematically indexed or catalogued at this time. This is a potentially very important source of information because the Natchituches F'ost (Fort St. Jean Baptiste aux Natrhitoches) was the first trade post maintained among the Caddoan groups and Spanish orrupants of the East lexas missions until about 1780 . French merchants and tradcrs working among the different Caddoan groups during Spanish administration in Natchitoches were required to have a license or permit with the authorities prior to conducting trading ventures. Information contained in these permits or contracts may prove to be important in tracing the history and use of Le Dout or other French trading posts in the Upper Sabine Basin.

${ }^{11}$ This is usually referred to as the Direct Historical Approach. See Julian H. Steward, "The Direct Historical Approach to Archaeulogy," American Antiquity, VII ( $\Lambda$ pr., 1942), 337-\$43. The implementation of this approach has been attempted on the basis of archaeological data on aboriginal material culture, the presence of European trade goods in the archaeological assemblages, and the identification of settlement locations from archaeological and historical information that coincidc in spare and time.

${ }_{12}$ Timothy K. Perttula, Bob D. Skiles, Michael B. Collins, Margaret C. Trachte, and Fred Valde7., Jr., "This Everlasting Sand Bed": Cultural Resources Investigations at the Texas Big Sandy Project, Wood and Upshur Counties, Texas, Reports of Investigations No. $5^{2}$ (Austin: Prewitt and $\Lambda$ ssuciates, Inc., 1986), 60.

${ }^{19}$ Albert E. Woldert, "Relics of Possible Indian Battle in Wood County, Texas," Sowhwestern Historical Qwarterly, LV (Apr., 1952), $4^{84}-4^{89}$.

${ }^{14}$ American State Papers: Indian Affairs, in Documents, Legislative and Executize, of the Congress of the United States ( $1780-1815)$, Vol. I, Class II (Washington, D.C.: Government Printing Office, 1832), 721-725; Ancrican State Papers: Foreign Relations, in Documents, Legislative and Executive, of the Congress of the United States (I $780-1815$ ), Vol. II, Class I (Washington, D.C.: Government Printing Office, 1832), 693-694 (quotation); Bolton, Texas in the Middle Eighteenth Century, 91-92; Herbert E. Bolton (ed.), Achanuse de Mezieres and the Louisiana-Texus Frontier, ${ }_{17} 68-1780 \ldots(2$ vols.; Cleveland: Arthur H. Clark Co., 1919-1914).

${ }^{15}$ I)aniel H. Usner, JT., "The Deerskin Trade in French Louisiana," in Procepdings of the Tenth Meeting of the French Colonial Historical Society, April I2-14, I484, cd. Philip P. Boucher (Bostont: University Press of America, Inc., 1985), 75-93 
In 1952 the Southwestern Historical Quarterly published a short article by Albert Woldert on a possible Indian battle in Wood County, Texas. ${ }^{16}$ Found at the Woldert site ( 4 WD $\mathrm{WD}_{33}$ ) were copper and brass fragments, iron knives, iron hatchets, glass trade beads, lead balls, broken and smashed French flintlock musket barrels (estimated to date about 1770), an undated silver coin, and a copper cross inscribed with "Holy Mother" in Spanish. "Tomahawks" and stone arrowheads were also reported to have been found in association with these Europeanmanufactured goods. ${ }^{17}$

These artifacts were found near a large artesian spring ${ }^{18}$ on Mill Race Creek about two miles south of Hainesville, Texas (fig. 1), and about ten miles east of Mineola, Texas. Because of the large number of battered and broken old gun barrels found around the spring, Woldert concluded that late in the eighteenth century "Indians living near the large spring may have been surprised by armed soldiers rushing down the high hill and may have retreated eastward up Mill [Race] Creek valley, or perhaps a battle could have begun toward the east and ended at or near the spring where most of the relics were found." 19

To unravel circumstances in which the historic materials were found, it is necessary to evaluate the site's local legend and lore, which may help to determine its archaeological context and research potential. ${ }^{20}$ The collection of artifacts described by Woldert has been recently studied and photographed by the authors. Woldert was able to examine the gun barrels and some gun parts in the collection of Frank Haines, the son of Christian Haines, on whose property they were discovered, but he did not describe the artifacts in any detail. The collection belonging to Frank Haines was handed down to his daughter, Ruth Haines Davis. ${ }^{21}$ Our aim in restudying the collection was to determine the age and context of the artifacts, including those apparently not mentioned by Woldert, as well as their origin and use. Specifically we hoped to determine whether the site's artifacts of European manufacture had been modified or employed in a manner consistent with either Indian or Eu-

\footnotetext{
${ }^{16}$ Woldert, "Relics of Possible Indian Battle in Wood County, Texas," $484-489$.

${ }^{17}$ Ibid., $4^{84}$ (quotations), $4^{8} 5-4^{89}$.

${ }^{18}$ The artesian spring is situated along the edge of the uplift caused by the formation of the Hainesville Salt Dome. See W[illiam] L. Fisher, Rock and Mineral Resources of East Texas, Report of Investigations No. 54 (Austin: Bureau of Economic Geology, University of Texas, 1965).

${ }^{19}$ Woldert, "Relics of Possible Indian Battle in Wood County, Texas," $4^{89}$.

${ }^{20}$ See Kay L. Killen, Helen Simons, and Virginia Wulfkuhle, "Northeast Texas Late Prehistoric Study Unit," in Resource Protection Planning Process for Texas, ed. Theodore M. Brown, Kay L. Killen, Helen Simons, and Virginia Wulfkuhle (Austin: Texas Historical Commission, 1982), 235.

"Sam Davis, son of Ruth Haines Davis and great-grandson of Christian Haines, graciously gave us permission to study the collection in his possession.
} 


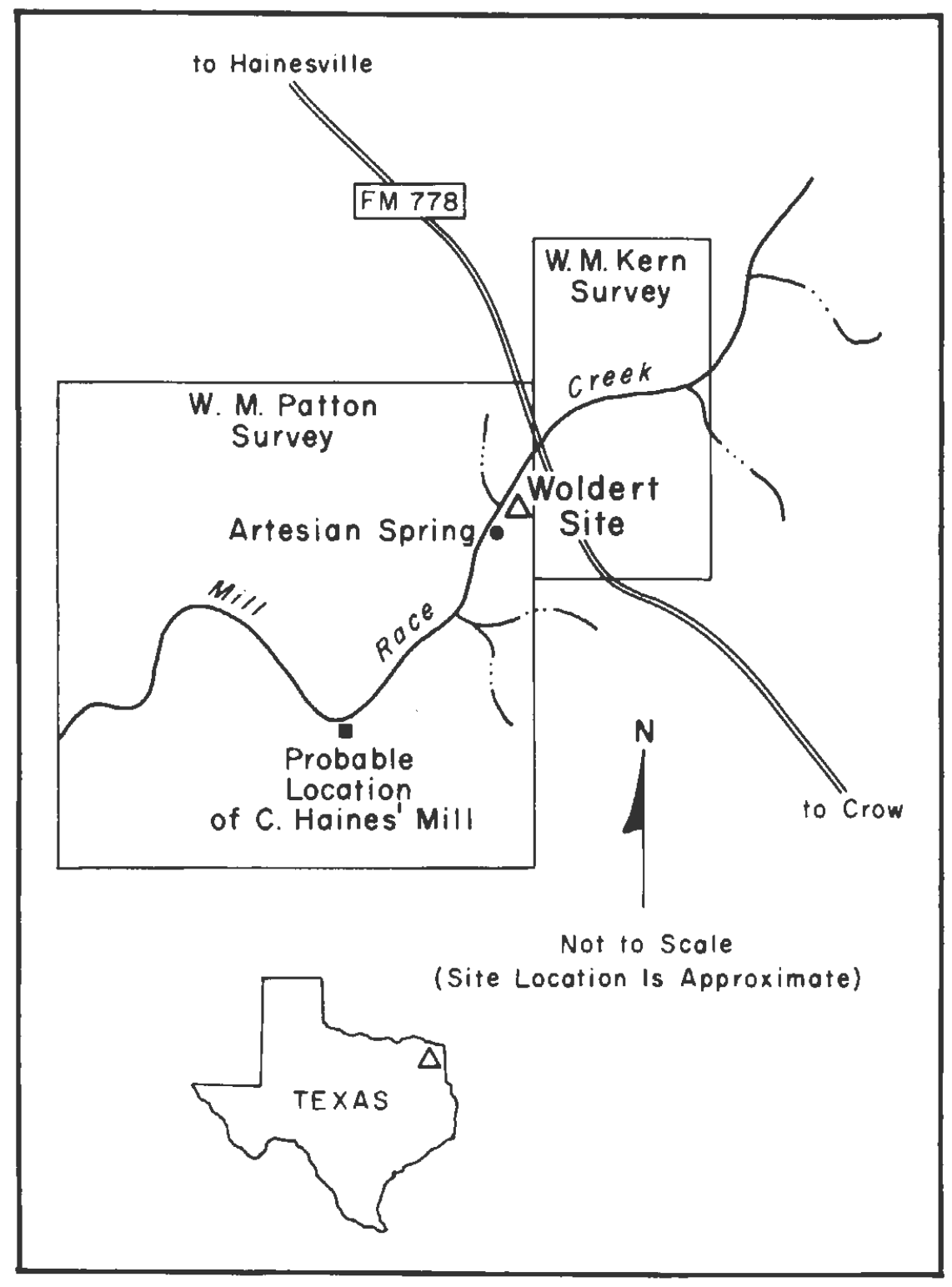

Figure 1. Location of the Woldert Site (4 I WD393) near Hainesville, Texas. 
ropean patterns of usage. ${ }^{22}$ Various alterations in the manufacture, form, or apparent function of European-derived material remains are utilized by archaeologists to infer aspects of aboriginal change in acculturative situations. The dating of European-manufactured goods such as knives, glass trade beads, and flintlock guns has been considerably refined since the 1950 , ${ }^{29}$ making chronological estimates fairly precise for archaeological sites presumed to date to the eighteenth century.

Woldert noted that the artifacts were found and collected from various farms on the W. M. Kern and W. M. Patton surveys in a two-milewide area around the spring (fig. 1). Local information indicates, however, that the majority of the guns were actually found accidentally by ditchdiggers working on Christian Haines' water mill.

According to a local resident, Johnie Moody, about 1870 Haines built a water mill in the Hainesville area. This mill was powered by water from an artesian spring only one-half mile northeast of the mill site on Mill Race Creek. Irishmen hired by Haines to dig the race ditch exposed at least twenty-five "antique" rifles, enough to cover the bottom of a wagon bed. ${ }^{24}$

These same ditchdiggers uncovered an unmarked Caucasian burial in 1874 on the Joe Moody Farm, located in the W. M. Kern Survey. ${ }^{25}$ This burial presumably predates the Anglo-American settlement of the redlands and Hainesville areas, which began around $1841 .{ }^{26}$ The burial had been placed in a split and hewn log used as a wood coffin. Local legend has it that this burial was the body of Sieur de La Salle, the French explorer who was murdered somewhere in East Texas in March, 1687 , while searching for the Mississippi River. ${ }^{27}$ This putative associa-

\footnotetext{
${ }^{22}$ Jeffrey Brain, Tunica Treasure, Papers of the Peabody Museum of Archaeology and Ethnology, Harvard University, Vol. 71 (Cambridge: Peabody Museum of Archaeology and Ethnology, 1979), 271-274. Discussing historic contact period sites, Brain distinguishes artifacts of aboriginal manufacture, which represent traditional techniques of manufacture, use, and function (such as pottery and stone tools), from those of aboriginal and European manufacture, which required new materials and techniques of manufacture, form, and function. These could include such unmodified itcms as brass gorgets, tinkling cones, axes, hoes, and firearms. When these are found on an archaeological site, they can represent various stages of innovation and aboriginal acculturation as well as evidence of European habitation. Thus, it is essential that a knowledge of artifact context and association be obtained from a site to sort out European influence on ahoriginal peoples from an actual occupation by a European group.

${ }^{23}$ Ibid., 33-223.

${ }^{24}$ Johnie (Mrs. A. L.) Moody, "Reminiscence of Hainesville," in Chips of Wood County, comp. Adele W. Vickery (Mineola: Adele W. Vickery, 1969), Part 2, 3 (quotation), 4 .

${ }^{25}$ Wood County Democrat (Quitman), Aug. 6, 1908.

${ }^{26}$ Wood County, 1850-19oo (Quitman: Wood County Historical Socicty, 1976).

${ }^{27}$ While the actual location where Sieur de La Salle was murdered is unknown, current think ing suggests it was in the vicinity of the Trinity River, at least 120 miles south of the Woldert site. See Robert S. Weddle, Wilderness Manhunt: The Spanish Search for LaSalle (Austin: Univer-
} 
tion with 1 a Salle ${ }^{28}$ was based primarily on the fact that many old guns had recently been found on the nearby Haines farm.

A 1908 article in the Wood County Democral had noted that

the guns and other relics found around there, and more especially [that] the guns were all bent or broken, showing the fact that the superstition of the Indians had been aroused owing to the fact that the bullets coming out of these guns killed their comrades, and they could not understand why such weapons should so mysteriously kill when there was nothing about them that they could see, to produce death. Mr. C. H. Haines, in his lifetime gathered up quite a number of these bent and broken guns. ${ }^{29}$

The obvious antiquity of the burial and the rifles found nearby suggesting La Salle's demise by Indians who had then broken the Frenchmen's guns, contributed by the 1940s to the general notion that the ared was the site of an Indian battleground. Woldert appears to have been convinced by the county lore. In a 1946 article the Mineola Monitor described the Haines collection as "old gun barrels which had been battered and broken in two, indicating a fight to the finish with Indians. It was the practice of the Indians in the early days to destroy the mysterious death-dealing firearms whenever they captured them." ${ }^{\text {no }}$ Woldert's study of these guns ultimately removed the La Salle association because Woldert felt that the flintlocks in the collection dated to the late 17 oos."

The evidence summarized in Woldert's article, combined with local legend, does indicate that a considerable quantity of European goods has been found around the artesian spring and at other places on Mill Race Creek. The number of guns found together in the mill race ditch implies a cache of guns, ${ }^{32}$ though it is still unclear whether the cache was deposited by Indians or Europeans. Giving a European attribution to the burial on the Joe Moody Farm seens logical in view of its apparent age and unusual mode of interment, but its association with the gun cache is still unknown.

Aboriginal and E.uropean-nanufactured goods in the Haines collection are a composite of occupations on Mill Race Creek beginning

sity of Texas Press, 1973); and Henri Joutel, A Journal of the Last Voyage Perform'd by Monsr. de La Sale, to the Gulph of Mexico... (1714; reprint, Ncw York: Corinth Books, 1962), 102-104.

${ }^{28}$ Wood County Democrat (Quitman), Aug. 6, 1yu8; Moody, "Reminiscence o[ Hainesvillc," 4.

${ }^{29}$ Wood County Democrat (Quitman), Aug. 6, 1908.

${ }^{30}$ Mineola Monitor, Nov. $22,1946$.

${ }^{31}$ Woldert, "Relics of Possible Indian Battle in Word County, Texas," 487.

${ }^{92}$ Caches of flintlock guns have been found at several aboriginal Indian sites of cightcenthcentury age. Scc T. M. I Hamilın (comp.), "Indian Trade Guns," Missouri Archosologist, XXII (Dec., 1960), 150-171; Jay (: Hlaine and R. K[ing] Harris, "Guns," Bulletin of the Texas Archeological Sociely. XXXVII $(1967), 33-86$. 
about 10,000 years ago. ${ }^{9 y}$ None of the aboriginal artifacts included in the collection are definitely of eighteenth-century manufacture. However, ground celts and clay pipes of similar form and manufacture have been recovered from such historic period sites in East Texas. ${ }^{34}$ A fragmentary clay pipe of "ring-base" style from the Woldert site has been recovered from the possible site of the French post (dating from the 1730 s to the 1770 ) among the Kadohadacho. ${ }^{35}$

The remainder of the collection is dominated by artifacts of eighteenth-century French manufacture. In addition to the fourteen octagonal gun barrel and muzzle sections, a number of other gun parts and iron, brass, or copper artifacts were present. Unfortunately, the glass trade beads, coins, and cross mentioned by Woldert are missing from the collection.

The guns represented in the Woldert site collection include at least four Type D French fusils or light muskets. ${ }^{36}$ ' The French guns are colonial frontier Hintlock muskets manufactured between 1730 and $17 \mathbf{6}_{5}$. These types of guns were made in France for trade, where they were shipped to the Colony of Louisiana for eventual distribution to Indians in exchange for pelts, bear oil, horses, and other supplies and as annual presents. $^{37}$

The Type D gun is noted in several Wichita and Caddoan eighteenth-century archaeological sites in East Texas. ${ }^{3 x}$ Gun-barrel bore

\footnotetext{
"See J. Peter Thurmond, "Latc Caddoan Social Group Identihcations and Sociopolitical Organization in the Upper Cypress Basin and Vicinity, Northeastern Texas," Bulletin of the Texns Archeological Suciety, LIV $\left(198_{3}\right), 18_{5}-200$. Included in the cullection is a Paleoindian $(10,000-8,000$ years ago) Scottshluff-type projectile point, a Middlc Archaic $(6,000-4,000$ years ago) Yarbrough-type dart point, and two Gary points and onc basally notched point dating to the Late Archaic period (4,000-2,150 years ago). Of uncertain temporal attribution ase a hematite gorget and a clay pipe stem.
}

${ }^{M}$ Jelks, "The Gilbert Site," 208; Miroir, Harris, Blaine, and McVay, "Bćnard de la Harpe and the Nassonitc Post," 21 g.

${ }^{95}$ Miroir, Harris, Blainc, and McVay, "Bénard de la Harpe and the Nassonite Post," Figures $6 \mathrm{c}$ and d illustratc the "ring-hase" style of clay pipe. For discussions of the post, huilt by Alexis Grappe, and the French garrison at the site, see Mildred M. Wedel, LaHarpe's 17 rg Post on Red River and Nearby Caddo Settlements, Bulletin yo (Austin: Texas Memorial Museum, 1978), 10-16; Dan I. lilores, Jefferson E' Suuhwestem Exploration: The Freeman E Custis Accuunls of the Red River Expedition of 1806 (Norman: University of Oklahoma Press, 1984); and Gilmurc, Frensh-Indian Interaction at an Eightenth-Century Frontier P'ost, 13-19, 33-40.

*6 T. M. Hamilton, Colonial Frontier Cuns (Chadron, Neh.: Fur P'ress, 1980), 31.

${ }^{37}$ See Brain, Tunica Treasure, Appendix B, for examples of supply lists and tradc goods shipped to the Louisiana Colony in the cightcenth rentury. Common and fine fusils cost between ten and sixteen liveres in 1701 and about twenty lives in the middle of the eighteenth rentury. A gun would have been worth about ten deer skins in the 1730 , according in N. M. M. Surrey, The Commerce of Lousisana during the French Regime, 1699-1 763, Columbia University Studies in History, Economirs, and Public Law, Vol. 71 (New York: Columbia Liniversity Press, 1916), 354-355.

${ }^{9 \mathrm{~B}}$ Wichita or Norteno sites includc Gilbert, l'earson, and possibly the Womack site in Northeast Texas. See Jelks, "The Gilbert Site"; 1)uffield and Jelks, The Pearson Site; and Harris, Harris, Blaine, and Blaine, "A Preliminary Archeological and Documentary Study of the Womack 
measurements and lead ball diameters suggest that the guns were 28 to 32 calibre, ${ }^{39}$ the standard bore for French trade guns of the eighteenthcentury. ${ }^{+0}$ Foliate scrolls and hunting scenes wcre engraved on the two sidc plates; these were common French designs for flintlocks of the 1730s." A bow-quiver design was engraved on one of the four cast hrass butt plates. ${ }^{2}$ Other gun parts include a trigger guard finial, ${ }^{49}$ two mainsprings, two gun cocks, and a breech plug.

The barrels include octagonal breech sections and round muzzle sections. None appear to have been flattened or deformed from breakage, though such flattened and reworked barrel sections have been reported from Indian sites where the barrels were made into diggers, stakes, fleshers, and scrapers. ${ }^{44}$

One of the iron tools in the collection resembles an adze or scraper, and it has been reworked from a piece of metal scrap $4^{\circ}$ millineters wide. Similar artifacts, formed from barrel hoops, were recovered from the nearby Gilbert site. ${ }^{45}$ Two single-bitted iron axes are in the collection, one of which appears to have also been used as a wedge. These snall axes reportedly cost fifteen sols apiece in the eighteenth century, ${ }^{46}$ roughly cquivalent to the cost of two deer pelts in the French Louisiana trade. ${ }^{47}$

Site, Lamar County, lexas." Caddoan sites with Type D guns include Millsey Williamson and Roseborough I ake. See Jones, "The Kinsloe Focus"; "T. M. Hamilton, Early Indian Trade (iuns, 1625-1775 (Iawton, Okla,: Muscum of the Great Plains, 1968); Miroir, Harris, Blaine, and McVay, "Bénard de la Harpe and the Nassonite Post," Figure 11; and Giluore, French-Indian Interaction at an Eighteenth-Century Frontir Post, Figurc II:2.

${ }^{39}$ This bore size was designed to shoot lead balls weighing $2 \times$ to 32 to the livre. One livre weighs $4^{89.50}$ grams according to Hamilton, Culonial Frontier Guns, 7 and Table 11.

+o Ibid., $125-133$.

"Sideplates identical to those at Woldert were found at the Gilbert, Womack, Pearson, and 'Trudeau sites. See Hlaine and Harris, "Guns," Figure $38 \mathrm{e}$; Harris, Harris, Blaine, and Blaine, "A Preliminary Archeologial and Documentary Study of the Womack Site, Lamar County, Texas," Figure 1sb; Duftield and Jelks, The Pearson Site, Figure 139: T. M. Hamilton, "Ciuns, Gunflints, Balls and Shot," in Brain, Tunica Truasure, 206-216. Thorston Lenk, The Flintlock (London: The Holland Press, 1965), Plate 126:2 (foliate scrolls) and Plate 129:1 (hunting scenes), depicts sideplate designs of the 1730 cra.

"2 For similar butt plates, see Blaine and Harris, "Cuns," Figures 37 h, and j; Harris, Harris, Blaine, and Bfaine, " $\Lambda$ Prcliminary Archeological and Documentary Study of the Womack Site, Lamar County, Texas," Figure 16e; Hamilion, Early Indian Trade Guns, Figures $\eta^{a}$ and d; and Hamilton, "Guns, Gunflints, Balls and Shot," 213.

${ }^{43}$ Type [) trigger guards are also illustrated by Blaine and Harris, "Guns," Figure 3yg; Hamilron, "Guns, Gunflints, Balls and Shot," 213 ; and Ilarris, Harris, Blaine, and Blaine. "A Preliminary Archeological and Documentary Study of the Womack Site, Lamar County, Texas," Figure 12i.

"Hamilton, "Indian 'Trade Guns," 126; Blainc and Harris, "Guns," 59.

${ }^{45}$ See R. K[ing] I Iarris, Inus M. Harris, and J. Ned Woodall, "Inols," Bulletir of the Texas Arch eological Society, XXXVII ( $\left.19 \mathfrak{G}_{7}\right), 18-32$ and Figures $24 \mathrm{~d}$ and $\mathrm{b}$.

46 Brain. Tunica Treasure, 140 .

${ }^{47}$ Surrey, The Commerce of Lomisiana during the French Regime, I699-1763. 
There are several fragments of cast brass kettles, including a repaired and riveted kettle bail ear. ${ }^{4 \mathrm{H}}$ These types of kettles, with a flat bottom, straight sides, and a diameter of up to $5^{\circ}$ centimeters are quitc common trade items at the $1730-1763$ Tunica Indian Irudeau site. ${ }^{19}$

'The three iron knives in the collection are very similar to French clasp knives, though no names of the French manufacturers are discernible on the heavily rusted blades. Knives of this type were popular trade items and have been found at a number of Caddoan and Wichita sites contemporaneous with the Woldert site. ${ }^{51}$

The only known aboriginal groups living in the Sabine Basin during the middle of the eighteenth century were the Nadaco (or Anadarko) Caddo on the Sabine River near the Rusk and Panola county line, ${ }^{51}$ and various Wichita groups on the Upper Sabine and its tributaries near the Blackland Prairie in Rains County (fig. 2). Wichita groups included the Taovayas, Tawakoni, and Yscani and the separate group of Kichai, though, according to De Mézières, in 1770 there werc other Wichita groups living on the Sabine River. ${ }^{52}$

Sometime between 1542 and 1717 Nadaco settlements were split between those on the Sabine River and ncwer settlements in the vicinity of the Nacao Caddo in the Angelina River drainage..$^{53}$ A 1717 map ${ }^{54}$ locates the southern Nadaco group near the Hasinai. Also depicted on

\footnotetext{
${ }^{4}$ These are Type A, Variety , kettles defined by Brain, Tunica Tronsure, 165. Similar kettes were also found at the Womack site: see Harris, Harris, Blaine, and Blaine, "A Prelininary Arclieological and Imoumentary Study of the Womack Site, Lamar County, Texas," Figure $22 \mathrm{~d}$.

${ }^{49}$ Brain, Tunira Treasure

5." Represented at the Woldert site are two Type 1 and one Type 2 clasp knives. Sites with Type 1 clasp knives include Gilbert. Trudeau, Warc Acres, Roscborough Lake, Wonlack, and Bryson-Paddock; see 1 larris, Harris, and Woodall, "Tonls," ligures 21 a-d; Brain, Tunica Treasure, 154; Jones, "I 'he Kinsloe Focus," Plate if; Miroir, Harris, Blaine, and McVay, "Bénard de la Harpe and the Nassonite Post," Figurc 8c; Harris, Hartis, Blaine, and Blainc, "A Preliminary Archeological and Documentary Study of the Womack Site, Lamar County, Texas," Figure 2 1a; John D. Hartley and Anm F. Miller, Archoological Investigations at the Bryson-Paddock Site. Oklahoma River Basin Survey Archeological Site Report 32 (Norman: University of Oklahoma, Oklahoma River Basin Survey, 1977). Figure lop. Type 2 knives have been found at contemporaneous sites such as (iilbert and Fatherland. Sce Harris, llarris, and Woodall, "Iools," Figures $21 \mathrm{C}-\mathrm{g}$; and Rohert S. Neitzel, The Grand Village of the Natchez Revisited: Excavations at the Futherland Site, Adams County, Mississitpri, 1972 (Jackson: Mississippi Departulent of Archives and History, 1983), l'late $32 \mathrm{~b}$.

${ }^{51}$ 'The Nadaco or Aradarko had a population of more than 100 in the 1770 and at least $2 y$ families and 150 individuals in 1828 . The Nadaco moved from the Sabine River to the Brazos River in the 1850 along with other East Texas Caddoan groups. See Swanton. Surce Material on the Hisiory and Ethnolngy of the Caddo Indians, 18, 95-101; Berlandier, The Indians of Texas in 1830,138 .

${ }^{52}$ Boltun, Athanase de Mṕzières and the Louisiana-Texas Frontier, I, 208-20y.

5y See John R. Swanton, Final Report of the L'nited States De Soto Expedition Commission (Washingmon, D.C.: Government Printing ()ffice, 1999), map no. $y$.

${ }_{54} \mathrm{~J}$. Senek, A Map of Louisiana and the Misstssippi River, 1717 , I.D. no. 11 34, I ouisiana Room (Northwestern Louisiana State University, Natchitoches, La.).
} 


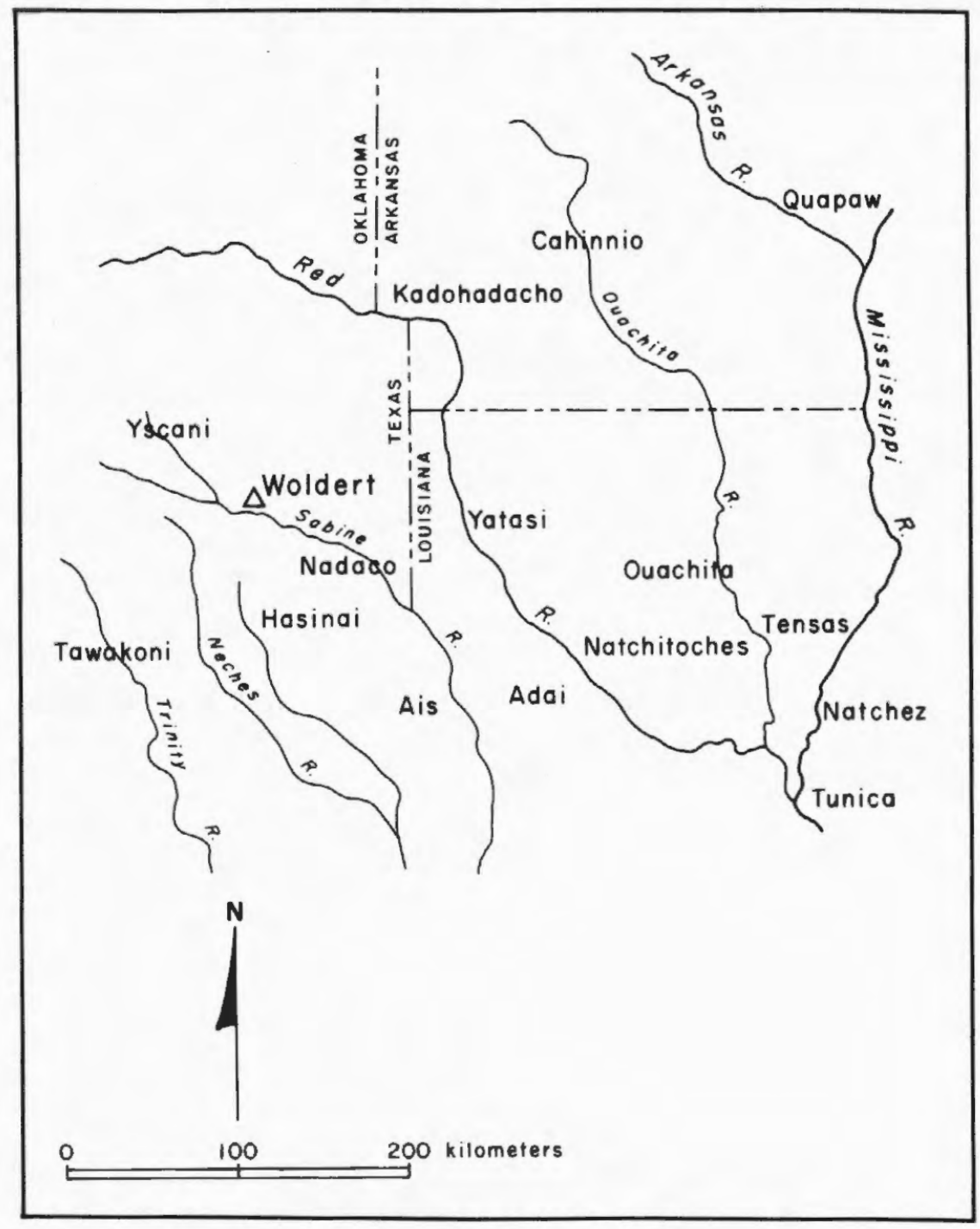

Figure 2. General location of Caddoan, Wichita, and other southeastern aboriginal groups and the location of the Woldert Site.

the same map are two forks of the Sabine River west of the Caddoan Ais and Adai tribes. They probably represent the Sabine River and Lake Fork Creek, its largest tributary. According to the map, there were no aboriginal groups living on this part of the Sabine River in 1717 . 
In $175^{2}$ the "Tebancanas," or Tawakoni, were described by the Nasoni Indians of the Hasinai Confederacy as living about twenty leagues ( 52 miles at 2.6 miles to the league) ${ }^{55}$ northwest from the Upper Angelina River. ${ }^{56}$ This would place the Tawakoni village on the Sabine River near its confluence with Lake Fork Creek, not far from the Woldert site (fig. 2). Wichita groups had begun to move out of the Arkansas River Valley south to the Red River between $174^{2}$ and 1757 , due in part to Osage harassment, and into the Sahine River Valley about the same time..$^{57}$

Visits by Fray Calahorra in 1760 and De Mézières in the $177^{\circ}$ s placed the Wichita groups on the Sabine River and its tributaries along the prairie-woodland margins. ${ }^{58}$ Fray Calahorra is fairly specific in placing the Tawakoni-Yscani villages "at the other side of the other arm of the Sabinas (Sabine) River." ${ }^{99}$ This "other arm" of the Sabine River was described by Fray Calahorra as a creek with "an abundance of water in pools," but it was not a permanently flowing stream in May, 1760 , when the journey from the Nacogdoches mission was made. The Fray Calahorra route and visit suggests that the Tawakoni-Yscani village was located on Lake Fork Creek in northeast Rains County.

In 1770 some of the Wichita groups had moved on to the Trinity and Brazos rivers, but based on archaeological evidence from the Gilbert and Pearson sites, ${ }^{60}$ the Upper Sabine Basin was still occupied at that time. The main villages of the Wichita were twenty-five or thirty leagues to the south-southwest, however. When Pedro Vial traversed the Upper Sabine Basin in August, 1788, he apparently followed the Tawakoni-Taovayas trail from the Red River to the Sabine River crossing. ${ }^{61} \mathrm{He}$ did not note any aboriginal settlements along the route once he left the Taovayas village on the Red River ${ }^{62}$ until he reached the Nadaco village near but west of the Sabine River. ${ }^{63}$

${ }^{55}$ See Susan C. Vehik, "Onate's Expedition to the Southern Plains: Routes, Destinations, and Implications for Late Prehistoric Cultural Adaptations," Plains Anthropologist, XXXI (1986), 13-39; Johnson and Jelks, "The Tawakoni-Yscani Village, $1760, " 414$ (quotation).

56 Johnson and Jelks, "The Tawakoni-Yscani Village, 1760," 414.

${ }^{57}$ Wedel, "The Wichita Indians in the Arkansas River Basin," 128.

${ }^{58}$ Bolton, Athanase de Mézières and the Louisiana-Texas Frontier, 1, 206-220.

${ }^{59} \mathrm{Johnson}$ and Jelks, "The Tawakoni-Yscani Village, $1760, " 412$.

${ }^{60}$ See Jelks, "The Gilbert Site," 244; and Duffield and Jelks, The Pearson Site, 80; Johnson and Jelks, "The Tawakoni-Yscani Village, $1760, " 412$ (quotation).

${ }^{61}$ Bolton, Texas in the Middle Eighteenth Century, 128-133.

${ }^{62}$ Dan L. Flores, Journal of an Indian Trader: Anthony Glass and the Texas Trading Frontier, 1790-1810 (College Station: Texas A\&M University Press, 1985), 6.

${ }^{65}$ Noel M. Loomis and Abraham P. Nasatir, Pedro Vial and the Roads to Santa Fe (Norman: University of Oklahoma Press, 1965), 342-345. 
Present evidence suggests that Vial crossed the Sabine River in southwestern Wood County near its confluence with Grand Saline Creek, ${ }^{64}$ about twenty miles west of the Woldert site. From the Sabine River crossing southeast to the Nadaco village was 25.5 leagues. The village had between thirteen and fifteen houses scattered over 3 leagues, but these were evidently located along tributaries of the Sabine River because the second Sabine River crossing by Vial was 5 or 6 leagues to the east. ${ }^{65}$ The presumed location of the Nadaco "village" in 1788 is in the vicinity of Tatum and Carthage, Texas-the same part of the Sabine River Basin in which post-1680 historic Caddoan archaelogical sites (referred to as the Kinsloe Focus) have been found. ${ }^{66}$ Known Kinsloe Focus sites extend from Longview, Texas, to the vicinity of Carthage, and all are located on tributaries to the Sabine River. This territorial relationship need not necessarily imply that the Kinsloe Focus is the archaeological correlate of the Nadaco Caddo, though the initial archaeological and ethnographic associations are supportive.

The American State Papers, Documents of the Congress of the United States $(1780-1815)$, include several valuable documents by John Sibley concerning eighteenth-century French trading establishments among aboriginal groups on the Sabine River. ${ }^{67}$ French traders lived among the many different aboriginal groups in the Caddoan area, operating as traders and coureur $d u$ bois from Natchitoches, New Orleans, or other French enclaves. ${ }^{68}$ Gregory notes that "French hunters operated from the Natchitoches post on a sort of share cropper basis. Men were outfitted with French firearms, flints, powder and shots to go to the vicinity of the Wichita to hunt hides." ${ }^{9}$

GH Ibid.

${ }^{65}$ Ibid., 346.

66 Jones, "The Kinsloe Focus," Figure 1.

${ }^{67}$ American State Papers: Indian Affairs; American State Papers: Foreign Relations. Dr. John Sibley, a Great Barrington, Massachusetts, native and physician, arrived in Natchitoches, Louisiana, a short time after the cession of Louisiana to the United States from Spain in 1803 . President Jefferson appointed Sibley an occasional agent to the Indian groups in Louisiana, including the Caddo, in 1804 , and gave him a full-time appointment as the Indian agent in 1805 . Sibley served as agent until 1815 , and the agency's headquarters remained in Natchitoches until 1821 . Sibley was an active agent with contacts throughout the LouisianaTexas border country and had a broad familiarity with the land and its aboriginal inhabitants. See John Sibley, A Report from Natchitoches in 1807 , ed. A. H. Abel, Indian Notes and Monographs (Museum of the American Indian, Heye Foundation, N.Y., 1922). For bibliographic data on Sibley sec G.P. Whittington, "Dr. John Sibley of Natchitoches, 1757-1837," Louisiana Historical Quarterly, (1927), 467-473; Flores (ed.), Jefferson E Southwestern Exploration; The Freeman $\mathrm{G}^{\mathrm{C}}$ Custis Accounts of the Red River Expedition of 1806, 30-31; and Helen H. Tanner, The Territory of the Caddo Tribe of Oklahoma, Caddo Indians IV (New York: Garland Press, 1974), $63-64,85,90-93$.

${ }^{68}$ Usner, "The Deerskin Trade in French Louisiana," 82.

${ }^{69}$ Gregory, "Eighteenth-Century Caddoan Archacology," 243. 
The peltry trade was an important part of the Louisiana economy, accounting for as much as 15 percent of the total exports in the mid1740 s. In 1756 the yearly contribution of the peltry trade was 120,000 livres. ${ }^{70}$ French voyageur Pierre Mallet described the operations of the French traders in a 1740 testimony thus:

That in Nachitoos (Natchitoches) there are few inhabitants other than the French soldiers. . . . From Natchitoos to Cadodachos . . . it is about fifty leagues toward the northwest. Between them are French settlements, as there are likewise at the said place of Cadodachos, though these French do not have fixed habitations, but only come and go to sell muskets and other things needed by the Indians, from who they obtain annually about 100,000 pounds of furs, as well as tallow and the oil of bears, buffaloes, and deer. ${ }^{71}$

The French had a trade station and military post on the Sabine River near where the Nadaco were living in $1805 .{ }^{72}$ Its location sixty to seventy miles west of the Yatasi and the French settlement Bayou Pierre (fig. 3) would place it in the same area as where the Nadaco were living in $1788 .{ }^{73}$ Vial, however, does not mention any French establishment in or near the Nadaco village, which suggests it had been abandoned some time prior to 1788 . Sibley also mentions another station and factory on the Sabine River "nearly a hundred miles northwest from the Bayou Pierre settlement." 74

John Baptiste Grappe, a resident of Natchitoches in 1805 , located a trading establishment on the east bank of the Sabine River "towards the head of said river." 75 This establishment was called Le Dout, the "redoubt" or "fortification." "Its location on the east bank of the Sabine River suggests to us a siting on Lake Fork Creek, the eastern fork of the Sabine River, rather than on the Sabine River itself.

François Grappe, John Baptiste Grappe's older brother, described Le Dout as follows:

On the Sabine River, near where the Nandaco (Nadaco or Anadarko) Indians now live; and that it was an ancient establishment, and a place of great trade and resort at the time his father's family lived at the Caddos; and that he has

\footnotetext{
${ }^{70}$ See Surrcy, The Commerce of Louisiana during the French Regime, 1699-1763.

"Quoted in C. W. Hackett (ed. and trans.), Pichardo's Treatise on the Limits of Louisiana and Texas ... (4 vols.; Austin: University of Texas Press, 1931-1946), III, p. 417, paragraph 670.

${ }^{72}$ American State Papers: Indian Affairs, 722; American State Papers: Foreign Relations, $693-694$.

${ }^{73}$ American State Papers: Indian Affairs, 722.

${ }^{74}$ Ibid.

${ }^{75}$ American State Papers: Foreign Relations, 693.

${ }^{76}$ We are indebted to Kathleen Gilmore for this interpretation of the etymology of "Le Dout."
} 


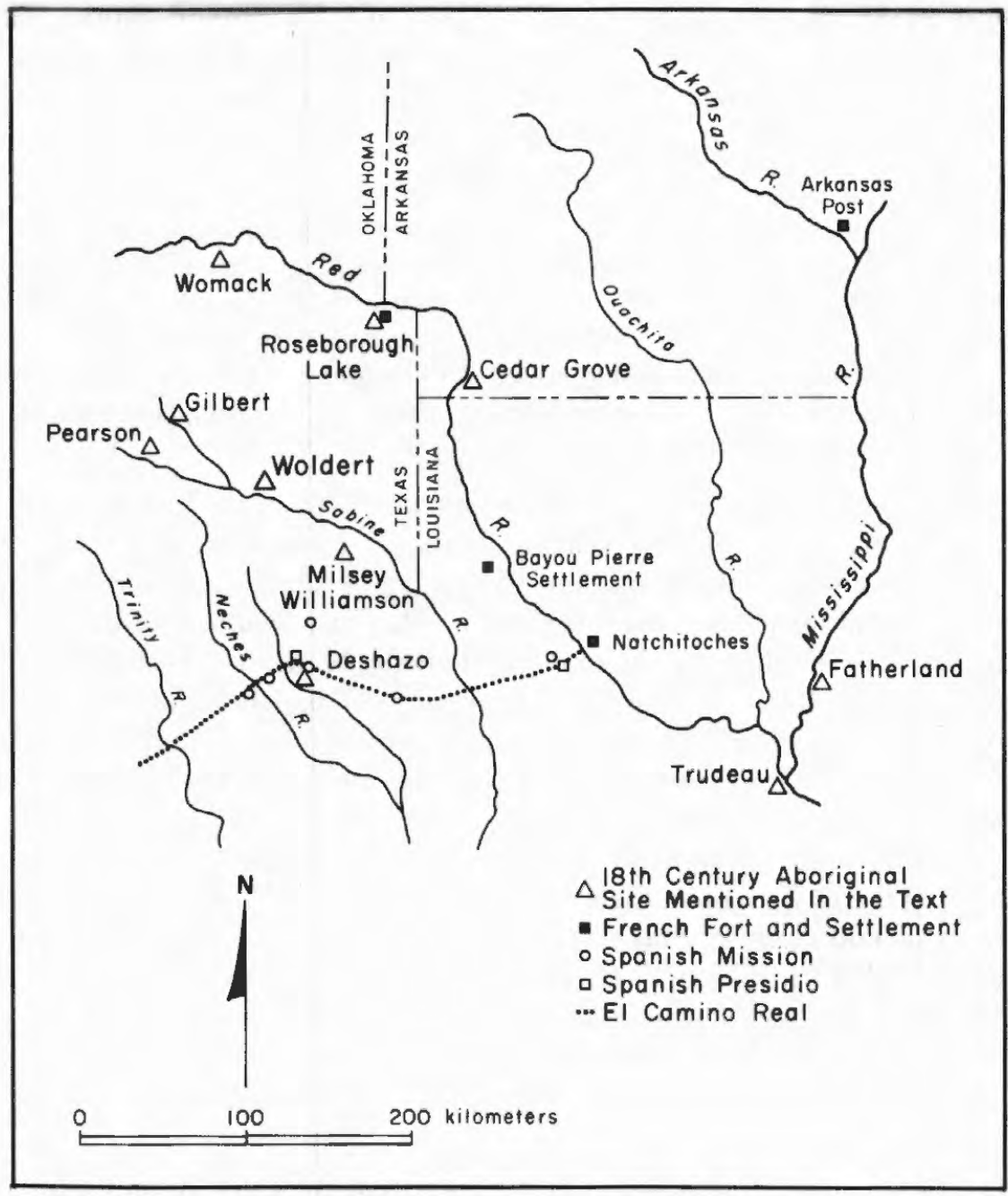

Figure 3. Spanish and French settlements and historic localities relative to the distribution of eighteenth-century Caddoan and Wichita archaeological sites.

several times been at the place; the French flag used to be hoisted there, and there are the remains of the buildings and works now to be seen; and that the Dout is about 150 miles northwest from Natchitoches. ${ }^{77}$

Another 1805 resident of Natchitoches, Louis Lamalty, described a French trading house, on the southwest side of the Sabine River but 15

${ }^{77}$ American State Papers: Foreign Relations, 693-694. 
or 16 miles from it, that was established prior to $1762 .{ }^{78}$ This trading house was 130 miles from Natchitoches.

While it is conceivable that the archival information reviewed here may relate to only one trade station, albeit with wide-ranging estimates on directions and distances from known French settlements, it seems more likely that there was more than one French trade station in the Upper Sabine Basin. Le Dout, as described by François and John Baptiste Grappe, could be in the general vicinity of the Lake Fork Creek confluence with the Sabine River. This would be consistent with its being at the head of the river and 150 miles from Natchitoches; the Woldert site is about 5 miles from the confluence of these two streams. The only testimony inconsistent with this purported location is François Grappe's suggestion that it was also near where the Nadaco lived. This would place it about 50 miles farther downstream, unless the Nadaco moved between 1788 and 1805 . Sibley's separation of two possible factories would place one near the Nadaco and the other upstream in the same area as Le Dout. Lamalty's testimony, however, seems to refer to the trading establishment at the Nadaco village. His description suggests it is on a tributary to the Sabine River, perhaps Martin Creek. The only area on the Sabine River where the "southwest side" makes sense topographically is between Cherokee Bayou and Murvaul Bayou in Rusk and Panola counties.

The French factory called Le Dout is the best candidate, therefore, for a separate trading establishment on the upper reaches of the Sabine River Basin prior to 1770 . If located on the headwaters, it is likely associated with Wichita groups who maintained villages and hunting camps on the upper tributaries of the Sabine at that time. ${ }^{79}$ If it was located nearer to the Lake Fork Creek-Sabine River confluence, any Caddoan or Wichita groups living west of the Nadaco may also have taken their furs to Le Dout. Lamalty ${ }^{80}$ also indicated that there were several other unnamed tribes then living on the Sabine River-other than the Tawakoni, Kichai, or Yatasi-who were participating in the French trade.

Is the Woldert site the French post called Le Dout? Is it the location of an Indian-European battle? On the basis of present information we do not think that the site was the location of a battle. The guns from the site probahly derive from a cache, and their broken condition can be explained simply by the dismantling of breech and muzzle sections when placed in the cache or by their exposure in the 1870 .

\footnotetext{
${ }^{78}$ Ibid., 693 .

${ }^{79}$ See the discussion by Bolton, Texas in the Middle Eighteenth Century, $9^{1-92}$ and n. 46 .

${ }^{80}$ American State Papers: Foreign Relations, 694 .
} 
The area adjacent to the artesian spring on Mill Race Creek where the Woldert site is believed to be located is presently covered by a dense understory of weeds, briars, tall grasses, and poison ivy as well as a twenty- or thirty-year-old oak-hickory overstory. It has not been cultivated for many years, and there is nothing visible to suggest the presence of an archaeological site. There have been several cursory visits in the last twenty-five years to Mill Race Creek to try to relocate the site, but at the present time its exact location remains unverified. ${ }^{81}$

The context of the other artifacts from the Woldert site is still unclear, however. The presence of French goods commonly exported to the Louisiana Colony as Indian trade items, particularly the fusils, kettles, and iron knives, may be expected on Indian habitation sites as well as in French trading posts. ${ }^{82}$ Except for the adze/scraper reworked from metal scrap, none of the artifacts have been modified in a manner suggesting aboriginal usage. This is difficult to assess with the limited range of artifact classes present in the Woldert site collection. In addition, acculturation of aboriginal groups may possibly affect patterns of artifact use to the point that they will appear similar to European manners of usage. ${ }^{83}$ The separation of varying functions and stages of acculturation cannot readily be determined until information on archaeological context and artifact associations is available. We are hesitant, therefore, to interpret the site as either an aboriginal or European one without further archaeological research.

Additional archival research is necessary to evaluate the possibility that the Woldert site is the location of the post called Le Dout. Testimony by French residents of Natchitoches in 1805 places the post near the Woldert site, but as yet no evidence of foundations or works suggestive of French buildings has been reported anywhere in the Upper Sabine Basin. If Woldert is the post Le Dout, we would expect not only concentrations of French goods at the site but also contemporaneous aboriginal sites in the vicinity, representing the habitations of the Indians who traded at Le Dout. The fact that mid-eighteenth-century French goods have been found in a two-mile radius around the Wol-

${ }^{81}$ Lathel E. Duffield and Sam Whiteside in 1959 were unable to relocate the locale where eighteenth-century historic period artifacts had been found. However, they did record a site on Mill Race Creek where artifacts of ahoriginal manufacture (4 1 WD217) were found (Carolyn Spock, telephone conversation, June, 1986). The junior author has found aboriginal Caddoan materials at four sites $\left(4, W_{329}-932\right)$ between one and two kilometers downstream from the artesian spring; one of these $\left(41 W_{331}\right)$ has a limited number of historic European artifacts.

${ }^{82}$ For a discussion of the character of a French colonial post see Gregory A. Waselkov, Fort Toulouse Studies, Auburn University Archaeological Monographs, No. 9 (Auburn: Auburn University, Dept. of Sociology and Anthropology, 1984).

${ }^{83}$ Brain, Tunica Treasure, 274. 
dert site is intriguing in this light, and this distribution may represent the immediate sphere of French influence among the local aboriginal groups. A site (41WD331) about one-half mile below the Woldert site contains a limited number of historic European artifacts such as beads and gun-barrel fragments as well as artifacts of aboriginal manufacture. ${ }^{84}$ This site is clearly an Indian settlement dating to the eighteenth century.

At this point we can only conclude that the Woldert site is a mideighteenth-century location containing abundant numbers of French trade guns. Its association with Le Dout, or with Indian settlements elsewhere on Mill Race Creek, remains problematical. We hope that with further research the Woldert site and other possible historic sites in the vicinity will contribute to a clearer understanding of IndianEuropean interaction and lifeways during this poorly understood period in East Texas history. ${ }^{85}$

${ }^{84}$ Perttula, Skiles, Collins, Trachte, and Valdez, "This Everlasting Sand Bed," 59.

${ }^{85}$ We would like to thank Kathleen Gilmore, Paul McGuff, and two anonymous reviewers for their useful comments about the manuscript. Gerald Blow of North Texas State University provided the figures. 


\section{CONCLUDING REMARKS: THE FUTURE OF UPPER SABINE RIVER BASIN ARCHAEOLOGY}

This is an exciting and challenging time in Caddoan archaeology. It is exciting because there is much interesting archaeological and ethnohistorical research (see Cruse 1995; Smith 1995) underway across the Caddoan archaeological area (which includes, of course, the Upper Sabine River basin in Northeast Texas), new but strong relationships are being forged between the Caddo peoples and the professional and avocational archaeological communities, and more people than ever are truly committed to the study, protection, and preservation of our state's and region's prehistoric and historic archaeological heritage.

Nevertheless, it is equally a challenging time. More than ever, archaeology is facing strong fiscal and regulatory restrictions now being proposed by the Federal Government that will hamper our already limited ability to successfully preserve and learn from important archaeological sites that would otherwise be damaged, destroyed, and lost by development projects on private, state, and federal lands (see Society for American Archaeology 1995).

Professional archaeologists have also badly handled one of most important roles: to be stewards of the past--stewards that seek to make the public aware of why it is important to preserve the past (Fagan 1995a)-- and engender a broad and lasting respect for archaeology's chronicling of human existence in all its diversity. Certainly, the recent efforts in sponsoring Archaeology Awareness Weeks across the nation, and in Texas, can help to overcome some of archaeology's worst public relations nightmares. However, the fact of the matter is that as long as archaeologists fail to publish the results of their work (indeed, as Fagan [1995b:17] notes, "by not producing final reports we are effectively looters ourselves"), fail to make their publications available to the interested public, but continue to churn out turgid reports that are as dry as the desert wind, and 
incomprehensibly jargon-laden, we come across as a "self-serving, special-interest group that keeps its finds to itself" (Fagan 1995b:17).

We also face in the Caddoan area one of the worst and insidious challenges: the looting and vandalism of Caddoan sites, mounds, and burials. Although the looting of Caddoan sites goes back to at least the 1930s, many Caddoan sites (Northeast Texas being no exception, particularly sites on the Red River and at the Corps of Engineers-Fort Worth District managed Lake o' the Pines on Big Cypress Bayou) in recent years have been completely destroyed within a matter of a few years by full-time looters specializing in the sale of ceramic vessels and arrowpoint caches (left by Caddoan peoples as grave goods to accompany the individual after their death) to wealthy antiquities collectors across the country. The looting, vandalism, and trafficking activities by commercially motivated looters has reached epidemic status throughout the Caddoan area, and threatens to disturb and destroy much, if not all, of the most significant and sacred Caddoan sites (see Perttula 1992). If effective solutions and actions are not developed and carried over soon, it will be tragic but true that much of the Caddoan archaeological record will have been forever depredated and desecrated.

It seems like a bleak picture. Maybe it is, but the story is still far from hopeless. While archaeologists wholeheartedly focus on understanding and predicting long-term changes in the near and distant past, we seem to hesitate when it comes to talking about the future. This piece is no different, but nevertheless it is useful to think about future directions in Caddoan archaeology: in this case, what we may look forward to, or need to accomplish in studying Upper Sabine River basin archaeology.

While there has always been strong ties between professional Caddoan archaeologists and avocationalists in Texas, Louisiana, Oklahoma, and Arkansas, in the future this relationship will become even stronger. This is part of a nation-wide trend in volunteer participation in archaeology (see Wertime 1995). 
Increasingly sophisticated and long-term avocational and professional research collaborations on Caddoan archaeology must become common in the Upper Sabine River basin. Such collaboration can be productive both in (1) designing and carrying out survey and excavation projects in critical areas and on threatened sites (such as those proposed in Fields and Tomka [1993] and Perttula [1993a, 1993b] from the Texas Historical Commission's planning document for the Northeast Texas Archeological Region), and (2) in fully studying, documenting, and publishing the findings from important provenienced avocational archaeological collections in the region (such as those of Sam Whiteside, a well known and respected avocational archaeologist who worked extensively in the Upper Sabine River basin in the 1950s-1970s).

In Northeast Texas, the Northeast Texas Archeological Society and the East Texas Archeological Society are embarking on such a course. The results of these valuable collaborative professional and avocational archaeological investigations are being completed and published (see Middlebrook 1994; Dockall 1994; Nelson et al. 1994; Speir and Jurney 1995), an annual East Texas Archeological Conference, started in 1993, has been a great success, and the Journal of Northeast Texas Archaeology is helping to insure that research results on Northeast Texas archaeology will be published in a timely manner.

It is important that these efforts continue to grow by leaps and bounds; given the dedication of avocational and professional archaeologists in the region, there is every reason to think that we will learn a great deal more about the prehistory and early history of the ancestors of the Caddo peoples who lived in the Upper Sabine River basin (and indeed the Caddoan area as a whole). With this new learning, then, and our commitment to engage the interested public in this endeavor to appreciate the past, hopefully we can meet the greatest challenge in the years ahead: to find a way to protect and preserve this cultural legacy. 


\section{ACKNOWLEDGMENTS}

I would like to thank the original Friends of Northeast Texas Archaeology--Bo Nelson, Mike Turner, Bob Skiles, and Tom Middlebrook-- for their support and encouragement of this project, and many other projects (finished as well as ongoing) in Northeast Texas. I also appreciate the support of others across the region who have joined with us in our archaeological research and publication efforts. Finally, I am very grateful for the advice, assistance, and research collaboration provided over the years by the coauthors of several of the papers in this compilation. 


\section{REFERENCES CITED}

Cruse, J. B.

1995 Archeology at the Oak Hill Village: A Caddoan Settlement in Rusk County. Heritage 13(1):10-14. Texas Historical Foundation, Austin.

Dockall, H. D.

1994 Human Skeletal Remains from the Tyson Site (41SY92). Journal of Northeast Texas Archaeology, No. 3:37-50.

Fagan, B. M.

1995a Perhaps We May Hear Voices... In Save the Past for the Future II: Report of the Working Conference, Breckenridge, Colorado, September 19-22, 1994, pp. $25-$ 30. Society for American Archaeology, Washington, D.C.

1995b Archaeology's Dirty Secret. Archaeology 48(4):14-17.

Fields, R. C. and S. A. Tomka, with contributions by T. K. Perttula

1993 Hunter-Gatherer Mobility in Northeast Texas. In Archeology in the Eastern Planning Region, Texas: A Planning Document, edited by N. A. Kenmotsu and T. K. Perttula, pp. 69-95. Cultural Resource Management Report 3. Department of Antiquities Protection, Texas Historical Commission, Austin.

Middlebrook, T.

1994 An Update of Archaeological Investigations at the Tyson Site (41SY92). Journal of Northeast Texas Archaeology, No. 3:1-36.

Nelson, B., T. Perttula, and M. Turner

1994 Caddoan Archaeology in the Little Cypress Creek Valley: Recent Investigations at the Griffin Mound Site (41UR142), Upshur County, Texas. Caddoan Archeology Newsletter V(No. 3):6-17.

Perttula, T. K.

1992 The Looting and Vandalism of Archaeological Sites in East Texas. American Society for Conservation Archaeology Report 18(2):3-13.

1993a The Development of Agriculture in Northeast Texas before A.D. 1600. In Archeology in the Eastern Planning Region, Texas: A Planning Document, edited by N. A. Kenmotsu and T. K. Perttula, pp. 121-146. Cultural Resource Management Report 3. Department of Antiquities Protection, Texas Historical Commission, Austin.

1993b Effects of European Contact on Native and Immigrant Indians in Northeast Texas. In Archeology in the Eastern Planning Region, Texas: A Planning Document, edited by N. A. Kenmotsu and T. K. Perttula, pp. 147-187. Cultural Resource Management Report 3. Department of Antiquities Protection, Texas Historical Commission, Austin.

Smith, F. T.

1995 The Caddo Indians: Tribes at the Convergence of Empires, 1542-1854. Texas A\&M University Press, College Station. 
Society for American Archaeology

1995 Save the Past for the Future II: Report of the Working Conference, Breckenridge, Colorado, September 19-22, 1994. Society for American Archaeology, Washington, D.C.

Speir, T. E. and D. H. Jurney

1995 Archaeological Investigations at the Marshall Powdermill and Arsenal (41HS17), Confederate States of America 1864-1865, Harrison County, Texas. Caddoan Archeology Newsletter 6(1):7-8.

Wertime, R. A.

1995 The Boom in Volunteer Archaeology. Archaeology 48(1):66-73. 